CARLOS ORLANDI CHAGAS

\title{
REPRESENTAÇÃO DA PESSOA JURÍDICA E A TEORIA DA APARÊNCIA
}

\author{
DISSERTAÇÃO DE MESTRADO \\ ORIENTADOR: PROFESSOR ROBERTO JOÃO ELIAS
}

FACULDADE DE DIREITO

UNIVERSIDADE DE SÃO PAULO

SÃO PAULO 


\section{CARLOS ORLANDI CHAGAS}

\section{REPRESENTAÇÃO DA PESSOA JURÍDICA E A TEORIA DA APARÊNCIA}

Dissertação apresentada à Banca Examinadora da Faculdade de Direito da Universidade de São Paulo, como exigência para obtenção do título de Mestre em Direito Civil, sob a orientação do Professor Associado Roberto João Elias do Departamento de Direito Civil da Faculdade de Direito da Universidade de São Paulo.

FACULDADE DE DIREITO

UNIVERSIDADE DE SÃO PAULO

SÃO PAULO 
Banca Examinadora 
Ao Professor Rui Geraldo Camargo Viana e ao Doutor Joaquim Portes de Cerqueira César, respectivamente, responsável por essa conquista e motivador do enfrentamento e superação desse desafio. 


\section{SUMÁRIO}

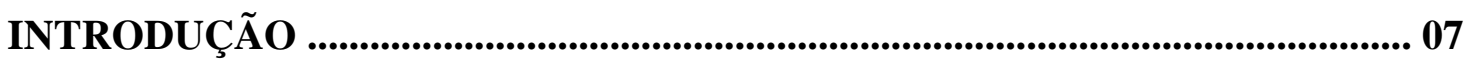

I - ASPECTOS GERAIS DAS PESSOAS JURÍDICAS ......................................... 08

1.1. Conceito e Definição de Pessoa Jurídica ......................................................................08

1.1.1. Enfoque da Congregação de Esforços e Efemeridada da Pessoa Natural...................14

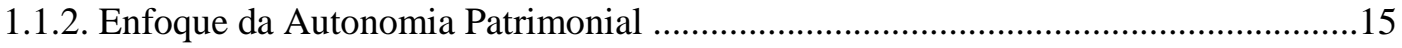

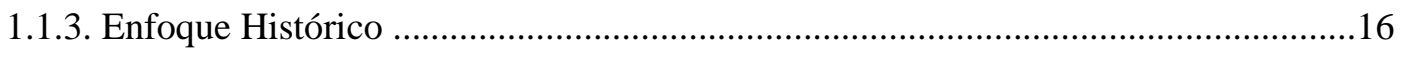

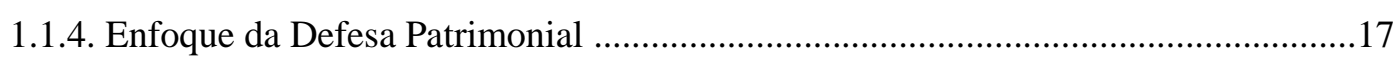

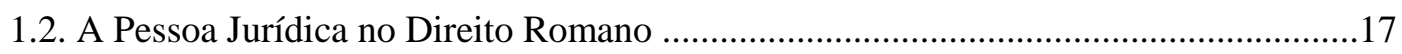

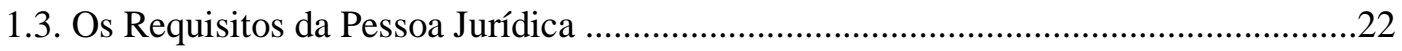

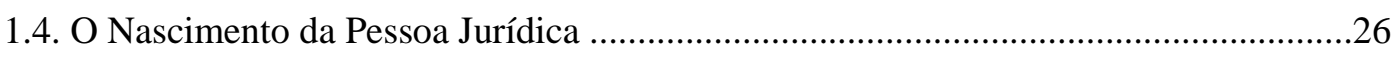

1.5. A Personalidade e a Capacidade da Pessoa Jurídica ..................................................... 34

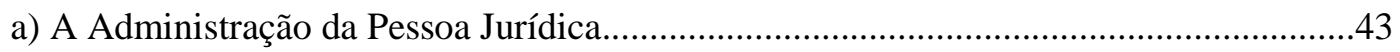

1.6. A Transformação da Pessoa Jurídica ...........................................................................46

1.7. A Desconsideração da Pessoa Jurídica .....................................................................48

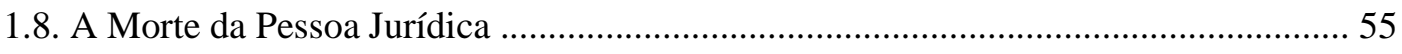

II - REPRESENTAÇÃO DA PESSOA JURÍDICA ............................................... 61

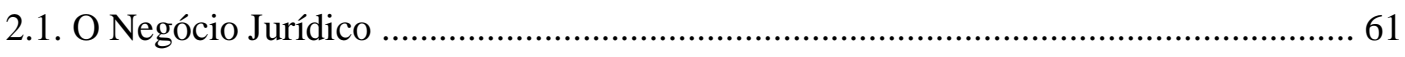

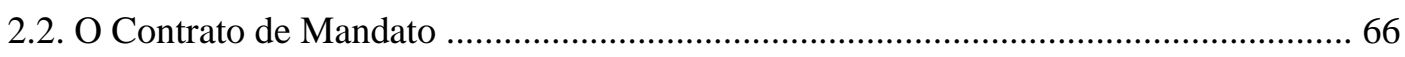

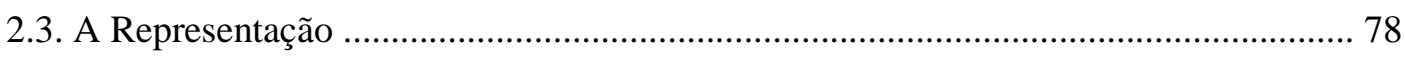

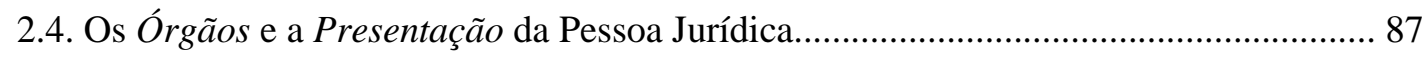

2.5. "Teoria da Aparência” - A (Re)presentação Aparente ................................................... 94

2.6. "Teoria da Aparência" na Jurisprudência do Supremo Tribunal Federal.......................100

a) Negócio Jurídico com (Re)presentante Aparente............................................................100 


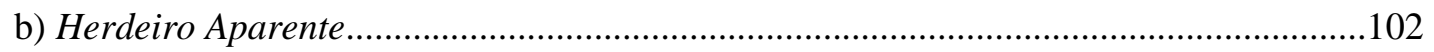

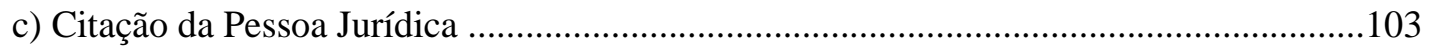

2.7. A "Teoria da Aparência” e a Jurisprudência do Superior Tribunal de Justiça...............103

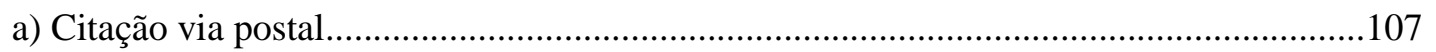

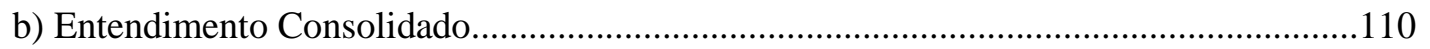

c) Conglomerado Financeiro - Cadernetas de Poupança.....................................................116

d) Conglomerado Financeiro - Revisão de Clásulas Contratuais.......................................118

e) Conglomerado Financeiro - Contrato de Seguro ...........................................................119

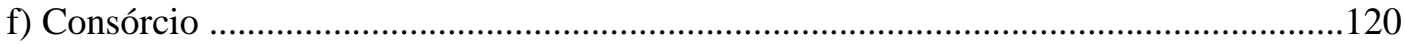

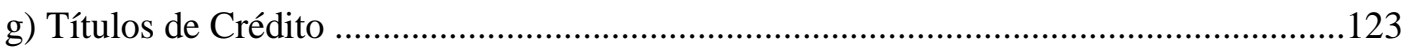

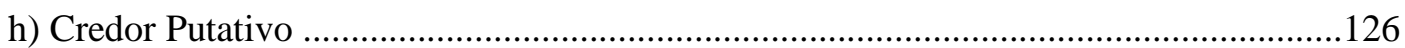

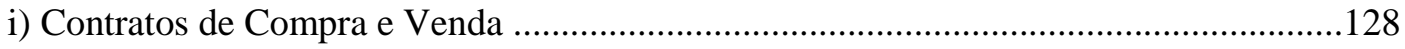

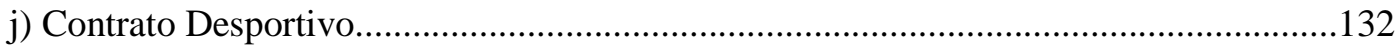

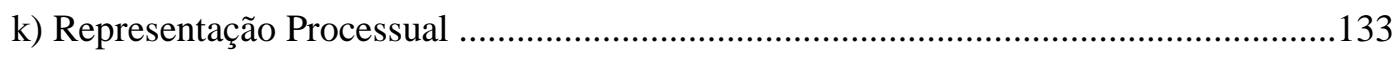

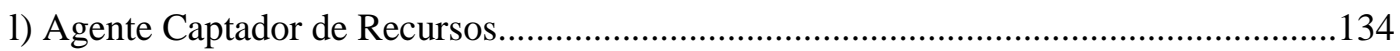

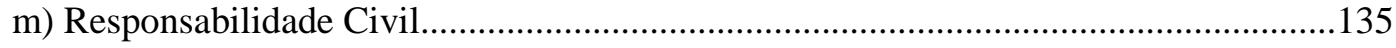

CONCLUSÃO

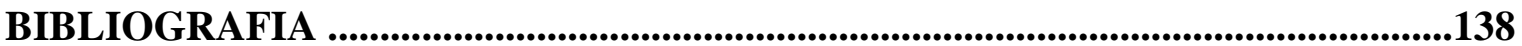




\section{INTRODUÇÃO}

O presente trabalho se divide em duas partes. A primeira delas, de caráter introdutório, tem a pretensão de percorrer, sucintamente, os principais aspectos doutrinários consagrados ao longo do tempo pela ciência jurídica a respeito das pessoas jurídicas, sempre com estribo nos ensinamentos dos juristas pátrios que se dispuseram a discorrer sobre o tema e sem incorrer no hercúleo desiderato de analisar, de forma específica e singular, nenhuma das modalidades desses entes abstratos descritos e reconhecidos pelo direito brasileiro.

Nesse primeiro impulso, faz-se necessário analisar os diferentes enfoques de conceituação da pessoa jurídica acolhidos pela doutrina, bem como investigar suas remotas origens no Direito Romano, além de apontar e discutir seus requisitos e o momento de seu nascimento, quando surgem as discussões atinentes aos efeitos do seu registro.

$\mathrm{O}$ aspecto fundamental nesse primeiro impulso é o estudo da capacidade e personalidade da pessoa jurídica, sua aptidão para ser sujeito de direitos, bem como de os exercer na ordem civil, pois nesse ponto reside parte da origem da problemática que será enfrentada na segunda parte.

Finalmente, aborda-se a transformação, desconsideração e a morte da pessoa jurídica, completando desse modo o seu ciclo vital.

A segunda parte se propõe a analisar a (re)presentação da pessoa jurídica, seja por meio de seus órgãos, verificando-se, nesta hipótese, a presentação, seja por meio de procuradores, sendo necessário, sob esse aspecto, o estudo do negócio jurídico, do contrato de mandato e da representação, em sua acepção técnica de negócio jurídico autônomo.

Percorrido esse caminho, é então possível enfrentar o fenômeno da Aparência de Direito ou Teoria da Aparência, sendo desenvolvida sua conceituação, bem como descritos seus requisitos essenciais e os efeitos de sua aplicação.

Finalmente, propõe-se a análise dos principais feitos judiciais levados a julgamento no âmbito do Supremo Tribunal Federal e do Superior Tribunal de Justiça, com a oportunidade de compreender como as Cortes Superiores brasileiras aplicam no caso concreto os institutos e fenômenos teorizados, especialmente a Teoria da Aparência. 


\section{I - ASPECTOS GERAIS DAS PESSOAS JURÍDICAS}

\subsection{Conceito e Definição de Pessoa Jurídica}

A pessoa jurídica, assim como a pessoa física, são construções da ordem jurídica, que lhes atribui direitos e obrigações. Em ambas está presente o suporte fático em que se alicerça o direito, sendo tão somente distintas em termos de caracterização e sendo anódina a discussão se são reais, visto que a realidade é algo dado como resolvido quando se adentra o mundo jurídico, que, repita-se, estriba-se em substratos fáticos ${ }^{1}$. A pessoa jurídica é tão oriunda do mundo fático quanto a pessoa física, residindo a distinção em que a primeira é produto da criação do homem, enquanto a segunda é fruto da natureza, porém cabendo ao direito nos dois casos reconhecê-las e protegê-las ${ }^{2}$.

1 F. C. Pontes De MiRanda, Tratado de Direito Privado - Parte Geral - Tomo I - Introdução. Pessoas Físicas e Jurídicas, $4^{\text {a }}$ ed., São Paulo, RT, 1974, p. 280:

"As pessoas jurídicas, como as pessoas físicas, são criações do direito; é o sistema-jurídico que atribui direitos, deveres, pretensões, obrigações, ações e exceções a entes humanos ou a entidades criadas por êsses, bilateral, plurilateral (sociedade, associações), ou unilateralmente (fundações). Em tôdas há o suporte fáctico; e não há qualquer ficção em se ver pessoa nas sociedades e associações (personalidade) e nas fundações: não se diz que são entes humanos; caracteriza-se mesmo, em definição e em regras jurídicas diferentes, a distinção entre pessoas físicas e pessoas jurídicas. Nem sempre todos os homens foram sujeitos de direito,nem só êles o foram e são. A discussão sôbre serem reais, ou não, as pessoas jurídicas é em tôrno de falsa questão: realidade, em lal sentido, é conceito do mundo fáctico; pessoa jurídica é conceito do mundo jurídico. O que importa é assentar-se que o direito não as cria ex nihilo; traz, para as criar, algo do nundo fáctico. Se há realidades espirituais (E. I. BEKKER, Was sind geistige Realitäten?, Archiv für Rechts - und Wirtschaftsphilosophie, I, 185-193), ou se não as há, constitui problema que se há de ter resolvido, ou dado como resolvido, antes de se entra.r no mundo jurídico. As teorias sôbre a pessoa jurídica aí se situam; são perspectivas do mundo fáctico, que apanham parte do mundo jurídico, mas sòmente porque o conceito de pessoa jurídica é conceito do mundo jurídico. A discussão sôbre ser ficção a pessoa jurídica apaga todos os elementos, com que o sistema jurídico trabalhou, para apontar, aqui e ali, pessoas jurídicas. (...)".

2 F. C. Pontes De MiRAndA, Tratado de Direito Privado - Parte Geral - Tomo I - Introdução. Pessoas Físicas e Jurídicas, $4^{\mathrm{a}}$ ed., São Paulo, RT, 1974, p. 281:

"A vida, o mundo fáctico, faz surgirem as pessoa físicas. Nasce o homem; o nascimento mesmo é fato jurídico. $\mathrm{O}$ direito apenas, atento à vida humana, de que é produto e meio, a protege desde a concepção e reconhece ao nascido a capacidade de direito. Não se passa o mesmo com as pessoas jurídicas. Pessoas jurídicas, quaisquer que sejam, criam-se. É o homem que as cria; ainda em se tratando do Estado: alguns homens o criaram, no passado; talvez um só, ou alguns, ou, por laguns, todos, conforme lhes pertencia o poder estatal. Quando os homens têm de constituir as pessoas jurídicas, praticam atos prévios, que são o dado fáctico, com que operam.

A pessoa jurídica é tão oriunda de fáctico quanto a pessoa física. (...)”. 
Nessa linha, a pessoa jurídica é real, da mesma forma que a pessoa física, restanto superado o individualismo romano e pós-romano que relutavam em construir a Teoria da Pessoa Jurídica, sempre inquinando-a com a idéia de ficção ${ }^{3}$.

Justamente porque é pessoa e, portanto, dotada de capacidade civil, a pessoa jurídica não demanda representação legal, visto que é capaz de obrar, praticando atos jurídicos, atos ilícitos e celebrando negócios jurídicos, sempre por meio de seus órgãos. A exata noção acerca do estágio de evolução de determinado sistema jurídico no tocante a concepção da pessoa jurídica se depreende de suas regras que disciplinam essa capacidade de obrar de per si do ente abstrato. O direito brasileiro, na linha do alemão, ressalvadas algumas reminiscências terminológicas, acolheu essa concepção mais moderna ${ }^{4}$.

3 F. C. Pontes de MiRAnda, Tratado de Direito Privado - Parte Geral - Tomo I - Introdução. Pessoas Físicas e Jurídicas, $4^{\mathrm{a}}$ ed., São Paulo, RT, 1974, p. 282:

"A pessoa jurídica é tão real quanto a pessoa física. O inividualismo romano e o pós-romano foram superados; aquêle, inapto a erigir a teoria das pessoas jurídicas, e êsse, hostil à aparição da teoria, a golpeavam com os conceitos de ficção. Ainda depois da teoria contemporânea, de fonte germânica $(\mathrm{H}$. PREUSS, Stellvertretung oder Organschaft?, Jherings Jahrbücher, 44, 421. 445 e 459 s.; C. CROME, System, I. 126; H. BAMBERG, Zur Lehre von der Deliktsfähigkeit der juristischen Personen, 31 s.; E. BILLMANN (Haftung der juristischen Personen, 9 s.), quis-se mostrar na teoria de O. VON GIERKE ficção (!) (...)".

4 F. C. PONTES DE MIRAnda, Tratado de Direito Privado - Parte Geral - Tomo I - Introdução. Pessoas Físicas e Jurídicas, $4^{\mathrm{a}}$ ed., São Paulo, RT, 1974, pp. 282 e 283:

“(...) Pois que é pessoa, a pessoa jurídica tem capacidade de direito. Pois que não precisa de representação legal, tem capcidade de obrar, capacidade negocial, de atos jurídicos stricto sensu, de atosfatos jurídicos e de atos ilícitos (O. VON GIERKE, Die Genossenschafstheorie, 663; G. KRÜGER, Die Haftung der juristischen Personen, 10; sem razão, E. LÖNING, Die Haftung des Staats, 54, excluía a capacidade delitual). Quem pratica os seus atos é o órgão, ou são os órgãos, se em caso de distribuição de funções; porque os órgãos são parte dela, como o braço, a bôca, o ouvido, são órgãos da pessoa física (O. VON GIERKE, Die Genossenschftstheorie, 615; G. KRÜGER, Die Haftung der juristischen Personen, 22; W. REINECKE, Die Haftung der juristischen Personen, 11). Para se saber se o sistema jurídico chegou à altura científica da concepção da pessoa jurídica dotada de órgãos, tem-se de verificar se nêle há regras jurídicas que correspondem a essa concepção e seriam repelidas por teorias regressivas. À aparição do Código Civil alemão, discutiu-se se ele adotara a concepção romanistica e a germânica, a cada vez (E. SCHLEGELMILCH, Die Haftung der juristischen Personen, 6), ou se tinha de adotar uma delas (cf. K. LINCKELMANN, Die Schadensersatzpfticht, $116 \mathrm{~s}$; K. SAENGER, Erläuterungen des $\S 81$ BGB., 5; FrOMBERG, Die Haftung des Fiskus, 48), ou exclusivamente a concepção germânica (e.g., W. REINECKE, Die Haftung der juristischen Personen, 5). A concepção de que a lei alemã e a brasileira partiram foi a concepção germânica, nas suas últimas formulações científicas. $\mathrm{O}$ que resta da velha concepção, dita romanística é, aqui e ali, reminiscência terminológica (e.g., arts. 15, verbo 'representantes', e 17, verbo "representadas"; Código Civil alemão, § 26). O órgão nem representa, nem tem a posição de representante legal (expressões do $\S 26$ do Código Civil alemão, que se têm de interpretar como 'à semelhança' do representante legal, cf. F. FUSSHÕ̃LER, Der Organbegriff, 21 S.; sem razão, E. SCHLEGELMILCH, Die Haftung der juristischen Personen, 23). Não seria de admitir-se que os dois Códigos houvessem deixado à ciência a questão (K. SAENGER, Erläuterungen des $\S 31$ $B G B, 5$ s.; K. RÖHRICH, Die Haftung des Staates, 5; sem razão: A. KORN, Deliktsfähigkeit des juristischen Personen, Festgabe für RICHARD WILKE, 184 s.; Chr. MEURER, Juristische Personen, 179)". 
A expressão pessoa jurídica, agasalhada pela tradição jurídica brasileira, remonta ao começo do século XIX, empregada por F. von SAVIGNY em substituição a outros termos como "pessoa mística" e "pessoa moral".

Os diversos autores e sistemas jurídicos ao redor do mundo, no entanto, não são unifiormes quanto a essa designação. Caio Mário da Silva PEREIRA ${ }^{6}$ dá notícia que, de fato, os Códigos Civis brasileiro e alemão, com espeque na assinalada existência dos entes abstratos em função do direito, dá-lhes o nome de pessoa jurídica e do mesmo modo procedem os Códigos Civis italiano e espanhol, enqunto o Código Civil Suíço usa a nomeclatura de pessoas morais, freqüente na doutrina francesa. No Brasil, Teixeira de Freitas em seu Esboço lançou mão do termo pessoa de existêncai ideal, que se contrapunha às pessoas de existância visível, estas as pessoas físicas, quedando-se reservada a denominação pessoa jurídica tão somente para os entes de direito público.

5 F. C. Pontes de Miranda, Tratado de Direito Privado - Parte Geral - Tomo I - Introdução. Pessoas Físicas e Jurídicas, $4^{\text {a }}$ ed., São Paulo, RT, 1974, p. 284:

"A expressão 'pessoa jurídica' vem do cômeço do século passado (A. HEISE, 1807). Substituíu outros, como 'pessoa mística' e 'pessoa moral'. Empregou-a F. vON SAVIGNY, o que lhe deu o prestígio que se seguiu (cf. O. vON GIERKE, Deutsches Privatrecht, I, 369; W. FreISTAEDT, Die Körperschaften, 5). Tal o nome que o Código Civil adotou".

${ }^{6}$ Instituiçães de Direito Civil - Introdução ao Direito Civil - Teoria Geral do Direito Civil, vol. I, $22^{\mathrm{a}}$ ed. atualizada por Maria Celina Bodin de Moraes, Rio de Janeiro, Forense, 2007, pp. 299 a 301:

"Não chegam os autores e os Códigos a um acordo quanto à designação destes entes. Pessoa jurídica é a denominação que lhes dá o Código Civil, em atenção à sua existência em função do direito, e mais, que somente no mundo jurídico podem ter expressão. Afirmam-se e produzem efeitos em razão do direito que lhes possibilita a criação. Pessoa jurídica é o seu nome no Código Civil alemão ( $\$ \$ 21$ a 89 do BGB). O Código Civil suíço (art. 53) as denomina pessoas morais, designaçao que é freqüentemente usada pela doutrina francesa, muito embora ali se encontre igualmente referência a pessoas jurídicas. Adotou o Código italiano (arts. 11 e segs.), como o Código espanhol (art. 35), o apelido pessoas jurídicas. A denominação, sem ser perfeita, dá a idéia de como vivem e operam estas entidades, acentuando o ambiente jurídico que possibilita sua existência, enquanto que aquela outra denominação (pessoa moral) tem menor força de expressão, por não encontrar sua razão de ordem no conteúdo de moralidade que as anima. Pessoa coletiva é outro nome usado, inaceitável, entretanto, por se impressionar apenas com a sua aparência externa, incidente no fato de freqüentemente se oginarem de um grupo ou uma coletividade de pessoas, mas inaceitável por excluir de sua abrangência todas as personalidades constituídas de maneira diversa de uma coletividade de indivíduos, o que se dá com as fundações, criadas mediance uma destinação patrimonial a um dado fim, como ainda o Estado, em cuja ontologia não tem predominância genética o agrupamento dos cidadãos. Das preferências de Teixeira de Freitas era a expressão pessoas de existência ideal, em contraposição às pessoas de existência visível, com que batizava as pessoas naturais, nomenclatura que perfllhou o Código Civil argentino (art. 32), onde, entretanto, a presença do nome pessoas jurídicas é a demonstração de que não foi aceita integralmente a técnica de Freitas, na qual somente as de direito público mereciam o nome de pessoas jurídicas. Não cremos, porém, que ao grande jurista assistiria razão quando enxergava maior latitude na designação por ele adotada, e menos ainda nos parece que somente as pessoas de direito público mereçam a qualiflcação de pessoas jurídicas. Outras designações, e numerosas, são lembradas pelos autores, como da preferência de uns e de outros, todas, porém, passíveis de critica: pessoas civis, pessoas místicas, fictícias, sociais, abstratas, intelectuuais, universais, compostas, corpos morais, universalidade de pessoas e de bens". 
De todo o modo, porém, como os entes abstratos ganham sua personificação do direito, que lhes reconhece, protege e atesta sua capacidade de ser sujeitos de direitos e obrigações, podendo obrar no mundo jurídico, a designação menos imperfeita á realmente a de pessoa jurídica ${ }^{7}$.

Fato é que ser pessoa para o Direito deriva, diretamente, da atribuição de direitos por parte do sistema jurídico. Nessa medida, ainda conforme o magistério de PONTES DE MIRANDA $^{8}$, ser pessoa é a possibilidade de ter direitos e esta possibilidade, de per si, é direito da personalidade. Tanto a pessoa física, quanto a pessoa jurídica, são criações do direito, que, com base em suporte fático, dá-lhes capacidade de direito. O que a velha concepção do direito romano não foi capaz de perceber é que a capacidade civil não depende da capacidade de obrar fisicamente, raciocínio que redundaria na conclusão de que um homem inválido não seria pessoa para o direito. Além do mais, tinha-se má

7 Caio Mário da Silva PereIRA, Instituições de Direito Civil - Introdução ao Direito Civil - Teoria Geral do Direito Civil, vol. I, 22 a ed. atualizada por Maria Celina Bodin de Moraes, Rio de Janeiro, Forense, 2007, p. 301:

"De todos os modos por que se podem designar, é a denominação pessoas jurídicas a menos imperfeita, e a que, pela conquista de campo na doutrina moderna, mais frequientemente se usa, e por isso mesmo a mais expressiva. Na verdade, se a sua personalidade é puramente obra de reconhecimento do ordenamento legal, e se somente na órbita jurídica e posslvel subordiná-las a critérios abstratos e reconhecer-lhes poder de ação e efeitos, o uso do nome deve obedecer a um critério hábil a sugerir de pronto estes fatores. Guardemos, portanto, fidelidade à nomenclatura para nós veramente tradicional: pessoa jurídica. (...)".

E prossegue o autor lembrando que o Direito Romano não conheceu essa designação, uma vez que somente o homem era cosiderado persona, sendo que a idéia de personificação de entes abstratos somente aparece nos períodos clássico e pós-clássico:

"Não podemos, porém, omitir que esta designação não é presente no direito romano como nos velhos romanistas. Somente o homem era persona. A. entidade coletiva dizia-se collegium, corpus, universitas. Também não se atribuía personalidade senão excepcionalmente, como no caso de herança ou do município, e mesmo assim não se falava que era uma pessoa, porém que fazia as vezes dela: "Hereditas personae vice fungitur, sicuti municipium et decuria et societas". Com o tempo, a idéia da personificacão dos entes coletivos ganhou extensão e, já na época clássica, podem ser apontadas duas categorias de universitates dotadas de personalidade: a universitas personarum, compreendendo os colégios, associações de publicanos, agrupamentos artesanais; e a universitas bonorum, verdadeiras fundações. A codificação justinianéia vem encontrar, como entidades corporificadas sob a inspiração cristã, conventos, hospitais, estabelecimentos pios".

8 Tratado de Direito Privado - Parte Geral - Tomo I - Introdução. Pessoas Físicas e Jurídicas, $4^{\mathrm{a}}$ ed., São Paulo, RT, 1974, pp. 284 e 285:

"O ser pessoa depende do sistema jurídico. Desde o momento em que regra jurídica, que a êle pertence, diz que A pode ter direitos, ainda que só o direito $b$, A é pessoa, porque a possibilidade de ter direito já é direito de personalidade. Se nem sempre há direito à personalidade, é tautológico que ter personalidade é ter direito de personalidade. Na verdade, não há pessoa sem direito; quem é pessoa pode ser sujeito de direito, e já o é do direito de personalidade (cf. ARTUR LEVY, Begriff und Rechtsnatur der Korporationsorgane, 11). A expressão 'pessoa jurídica', terminus technicus desde HEISE, em 1807, mas divulgado por F. VON SAVIGNY, não serve para se ter a pessoa jurídica como criação artifical do direito. O homem, as sociedades e associações, o Estado, o Distrito Federal, o Estado-membro, o Muncicípio e as fundações sòmente são, todos, pessoas, porque o sistema jurídico os tem como capazes de direito. (...)". 
compreensão acerca do fato de que todo o direito se faria no interesse do homem e não que somente o homem é que seria sujeito de direito 9 .

E vale mencionar que a velha concepção romanísitica, porque confundia a os conceitos de personalidade e vontade, exigia que para ser pessoa se deveria dispor do poder de consentir, o que não não se verificava no direito germânico para o qual sendo o homem parcela do todo, ao praticar determinado ato, ele o faz pelo todo e, portanto, se o órgão pratica determinado ato, é também o todo que o perfaz. Desse modo, aquele que tem órgão, tem também o poder de consentir e por isso o órgão não representa, mas é a própria pessoa. Essa foi a concepção do velho Código Civil de 1916 e que permanece no atual, neste ponto ambos com inspiração claramente germânica ${ }^{10}$.

Clovis Bevilaqua, por ocasião dos trabalhos em torno do velho Código Civil Brasileiro de 1916, já alertava que a ciência jurídica ainda não tinha fixado em caráter definitivo as idéias básicas da teoria das pessoas jurídicas, mas acerca das quais caberia ao

9 F. C. Pontes de Miranda, Tratado de Direito Privado - Parte Geral - Tomo I - Introdução. Pessoas Físicas e Jurídicas, $4^{\mathrm{a}}$ ed., São Paulo, RT, 1974, p. 285:

“(...) $\mathrm{O}$ direito romano não havia percebido suficientemente que à capacidade de direito não é necessária a capacidade de obrar; e raciocinava: se não pode obrar não é pessoa. Ora, o homem, absolutamente incapaz de obrar, é pessoa, e não se justificaria que, por isso, não se admitisse a personificação de entidade que não fôsse o homem. Por outro lado, o 'omne ius hominum causa (factum est)', que se lê na L. 2, D., de statu hominum, 1, 5, foi lembrado para se ter como fingida a pessoa jurídica. Ora, tal enunciado não se há de traduzir com 'sòmente o homem pode ser sujeito de direito', mas sim como “todo direito sòmente se faz no iinterêsse do homem'. Exatamente, com as criações naturais (sociais) do Estado, do Município, das sociedades e das associações, das fundações e das entidades de direito público, o homem colima satisfazer interêsses seus, e o direito, hominum causa. factum, atribui a personalidade a tais criações, ou acabou pelas reconhecer, como acabou por atribuir personalidade a todos os homens. Não foi o direito que as criou, se bem que o legislador, pondo-se no lugar do manifestante de vontade criativa (ato constitutivo), possa criar alguma. O dado real, que está no suporte. fáctico da pessoa jurídica, é tão real como o que está no suporte fáctico da pessoa física (O. VON GIERKE, Das Wesen der mensehtiehe Vervände, 10; Deutsches Privatrecht, I, 470). (...)”.

10 F. C. Pontes DE MiRAndA, Tratado de Direito Privado - Parte Geral - Tomo I - Introdução. Pessoas Físicas e Jurídicas, $4^{\mathrm{a}}$ ed., São Paulo, RT, 1974, pp. 285 e 286:

"Quando o direito romano se punha na atitude de quem exige para ser pessoa o poder consentir (L. 1, $\S$ 22, D., de adquirenda, vel amittenda possessione, 41, 2: 'universi consentire non posunt') era coerente, porque confundia vontade e personalidade, razão para admitir contra elas a pretensão de enriquecimento (L. 27, D., de rebus creditis, 12, 1) e não admitir que em dolo incorressem (L. 15, § 1, D., de dolo, 4, 3). Possuir e usucapir podiam por intermédio de outrem (L. 1, § 20, D., de adquirenda vel amittenda possessione, 41, 2), devido a concepção romana da intermediariedade, inconfundível com a da. reprentação, contemporânea. No direito gennânico, o homem é parcela do todo, de modo que, praticando o ato jurídico, pelo todo, como se o todo o praticasse (E. LONING, Die Haftumg des Staates, 27), e não se poderia pôr a questão de ser ou não ser incapaz de obrar. Quem tem órgão pode consentir, pois que o órgão pode, e assim seria sem pertinência o "universi consentire non possunt" (cf. O. VON GIERKE, Das deutsche Genossenschaftsrecht, III, 186 s.). O órgão não representa; presenta, pois é órgão. Tal a concepção do Código Civil brasileiro, de fonte germância. As pessoas jurídicas não são incapazes de obrar, pois têm órgão; o que o filho sob o pátrio poder poder, o tutelado e curatelado não têm: a esses alguém representa ou assite. (...)". 
legislador já então positivar regras ${ }^{11}$. Lembrava que o desenvolvimento do conceito de personalidade foi fruto de longo trabalho de abstração e generalização até aquele momento inconcluso, o que dava à teoria a complexidade refletida nos diversos estatutos civis ${ }^{12}$.

Hodiernamente, a definição de pessoa jurídica varia entre os vários doutrinadores que cuidam do tema conforme o enfoque que cada um deles adota para conceituá-1a ${ }^{13}$.

11 Clovis Bevilaqua, Em defeza do Projecto de Codigo Civil Brazileiro, Rio de Janeiro, Francisco Alves, 1906, pp. 64 e 65 :

"A theoria das pessoas juridicas é uma das mais interessantes do direito civil; mas, infelizmente, ainda a sciencia não firmou definitivamente todas a idéas basilares sobre as quaes tem o legislador de erguer construcções".

12 Clovis Bevilaqua, Em defeza do Projecto de Codigo Civil Brazileiro, Rio de Janeiro, Francisco Alves, 1906, pp. 65 e 66:

"Mas si, transportando idéas de hoje para phenomenos de outras épocas, é licito dizer que as pessoas juridicas de direito publico precederam as naturaes que dellas se foram, pouco a pouco, destacando, como de uma nebulosa primitiva, é certo, por outro lado, que, depois de integradas, as pessoas individuaes começaram a associar-se para mais facilmente conseguirem determinados fins, e é também exacto que transportaram a noção de pessoas a universidades de bens, egualmente unificados, em vista de um fim a realisar.

Esse desenvolvimento progressivo da idéa da personalidade não se effectuou sem um longo trabalho de abstracção e generalisação, que por não ter ainda ultimato emprestou à theoria uma certa complexidade que se tem reflectido nos codigos civis."

13 O atual Código Civil não cuidou de conceituar a pessoa jurídica, começando a tratar do instituto no seu art. 40, mas já partindo para sua classificação. Assim, dividem-se as pessoas jurídicas entre as de direito público interno e externo e as de direito privado (art. 40). As de direito público interno são a União Federal, os Estados, o Distrito Federal e os Territórios, os Municípios e os entes regidos pelo direito público da Administração Pública Indireta ou Descentralizada das três esferas de poder (Federal, Estadual ou Distrital e Municipal), como as Autarquias e as Fundações Públicas. Inovando, o Código Civil - alterado pela Lei 11.107/05 - acrescentou ao rol as Associações Públicas, roupagem jurídica dos consórcios públicos, utilizados, fundamentalmente, na área de saúde pública (art. 41). As pessoas jurídicas de direito público externo são definidas como sendo os Estados Estrangeiros, inclusive a Santa Sé, e as demais pessoas regidas pelo Direito Internacional Público, como as Organizações Internacionais (art. 42).

No âmbito do direito privado, temos como espécie de pessoa jurídica as Associações e as Fundações e, posteriormente incluídos - Lei 10.825/03 -, os Partidos Políticos (Lei 9.096/95 - Lei Orgânica dos Partidos Políticos) e as Organizações Religiosas, os quais, juntamente com os Sindicatos, tem natureza de Associação, regendo-se também pelas disposições do Código Civil nesse tocante (Enunciado 142 do CEJ: "Os partidos políticos, os sindicatos e as associações religiosas possuem natureza associativa, aplicando-se-lhes o Código Civil"). Finalmente, aparecem as sociedades, que podem ser civis ou empresariais, sendo, necessariamente civis as Cooperativas, e, necessariamente empresariais, as Sociedades Anônimas (art. 982).

Eis a dicção do Código Civil:

"Art. 40 - As pessoas jurídicas são de direito público, interno ou externo, e de direito privado.

Art. 41 - São pessoas jurídicas de direito público interno:

I - a União;

II - os Estados, o Distrito Federal e os Territórios;

III - os Municípios; IV - as autarquias, inclusive as associações públicas;

$\mathrm{V}$ - as demais entidades de caráter público criadas por lei.

Art. 42. São pessoas jurídicas de direito público externo os Estados estrangeiros e todas as pessoas que forem regidas pelo direito internacional público.

(...)

Art. 44. São pessoas jurídicas de direito privado:

I - as associações;

II - as sociedades; 


\subsubsection{Enfoque da Congregação de Esforços e da Efemeridade da Pessoa Física}

Washington de Barros Monteiro e Sílvio de Salvo Venosa entendem a pessoa jurídica como resultado da vontade humana em congregar esforços na busca de um objetivo comum ${ }^{14}$.

Nessa medida, a pessoa jurídica é fruto da vontade humana que cria entes abstratos, congregando pessoas naturais ou um patrimônio, a fim de levar a cabo empreendimento, cuja consecução não seria exeqüível por uma pessoa isoladamente e cuja sorte não poderia quedar ao alvedrio da efemeridade da vida humana e dos limites da pessoa natural ${ }^{15}$.

Na mesma linha, fica consignado que a pessoa jurídica como sendo as associações ou instituições por meio das quais uma pessoa natural acrescenta sua atividade à de seu semelhante, ou seus semelhantes, multiplicando suas possibilidades de execução de obras em favor da comunidade em que vive ${ }^{16}$.

III - as fundações;

IV - as organizações religiosas;

$\mathrm{V}$ - os partidos políticos.

$\S 1^{\circ}$ - São livres a criação, a organização, a estruturação interna e o funcionamento das organizações religiosas, sendo vedado ao poder público negar-lhes reconhecimento ou registro dos atos constitutivos e necessários ao seu funcionamento.

(...)

$\S 3^{\circ}$ - Os partidos políticos serão organizados e funcionarão conforme o disposto em lei específica".

14 Clovis BeVILAQua, da mesma forma, nos escritos Em defeza do Projecto de Codigo Civil Brazileiro, p. 65 (nota 3) já comungava desse viés de conceituação:

"O que determina a creação deste segundum genus de pessoas é o interesse social, porque, como ensina CHIRONI, « há fins que a pessoa isolada não poderia alcançar ou que são inherentes á destinação de um patrimonio»".

15 Sílvio de Salvo Venosa, Direito Civil - Parte Geral, vol. 1, $3^{\text {a }}$ ed., São Paulo, Atlas, 2003, p. 249:

"O homem, ser humano, é dotado de capacidade jurídica. No entanto, é pequeno demais para a realização de grandes empreendimentos. Desde cedo percebeu a necessidade de conjugar esforços, de unir-se a outros homens, para realizar determinados empreendimentos, conseguindo, por meio dessa união, uma polarização de atividades em torno do grupo reunido.

Daí decorre atribuição de capacidade jurídica aos entes abstratos assim constituídos, gerados pela vontade e necessidade do homem. Surgem, portanto, as pessoas jurídicas, ora como conjunto de pessoas, ora como destinação patrimonial, aptidão para adquirir direitos e contrair obrigações".

16 Washington de BArros Monteiro, Curso de Direito Civil - Parte Geral, $41^{\mathrm{a}}$ ed. atualizada por Ana Cristina de Barros Monteiro França Pinto, São Paulo, Saraiva, 2007, p. 126:

"Com justeza já se afirmou anteriormente que o espírito de associação obedece, em todas as suas manifestações, a duas forças fundamentais, simultâneas e concorrentes: $a$ ) - de um lado, a tendência inata do homem para o convívio em sociedade; $b$ ) - de outro, a acenada vantagem que resulta da conjugação de forças e que expressa pelo princípio mecânico da composição das forças no paralelogramo e segundo o qual o efeito da resultante é o produto e não a soma aritmética das forças agrupadas.

Surgem assim a pessoas jurídicas, também chamadas pessoas morais (no direito francês) e pessoas coletivas (no direito português) e que podem ser definidas como associações ou instituições formadas para a realização de um fim e reconhecidas pela ordem jurídica como sujeitos de direitos". 


\subsubsection{Enfoque da Autonomia Patrimonial}

Com outro enfoque, o da distinção entre o ente abstrato e os seus membros ${ }^{17}$, constrói seu conceito Sílvio RODRIGUES ${ }^{18}$, frisando que as pessoas jurídicas são entidades para as quais o ordenamento jurídico concede os atributos da personalidade, facultandolhes serem sujeitos de direitos e obrigações.

Caio Mário da SILVA PEREIRA ${ }^{19}$ elabora sua definição encampando os dois vieses mencionados, justificando, dessa maneira, sua criação na necessidade humana de conjugar esforços e capitais, com o escopo de levar a cabo grandes projetos, impossíveis de serem executados isoladamente, além de não poderem quedar ao sabor da efemeridade da vida humana Além do mais, invoca o brocardo jurídico societas distat a singulis, para enfatizar a distinção entre a pessoa jurídica e seus integrantes, lembrando que a pessoa jurídica não

17 Assim também leciona F. C. PONTES DE MIRANDA, Tratado de Direito Privado - Parte Geral - Tomo I Introdução. Pessoas Físicas e Jurídicas, 4ª ed., São Paulo, RT, 1974, p. 289:

“As pessoas jurídicas', diz o art. 20, 'têm existência distinta da dos seus membros'. Não se trata, a rigor, de regra jurídica. Apenas, tautològicamente se enuncia que as pessoas jurídicas têm capacidade de direito, que as pessoas jurídicas são pessoas. Além disso, as pessoas jurídicas, ainda que tratem com os seus membros, se a lei e o ato constitutivo não lhes veda tais negócios jurídicos, ficam como pessoas diante das pessoas dos seus membros. Aquêle que lhe compra, ou vende alguma coisa, ainda que assine por ela, como seu representante ou órgão, não faz contrato consigo mesmo. (...)”.

18 Direito Civil - Parte Geral, vol. 1, 34ª ed., São Paulo, Saraiva, 2007, p. 86:

"A esses seres, que se distinguem das pessoas que os compõem, que atuam na vida jurídica ao lado dos indivíduos humanos e aos quais a lei atribui personalidade jurídica, ou seja, prerrogativa de serem titulares do direito, dá-se o nome de pessoas jurídicas, ou pessoas morais.

Pessoas jurídicas, portanto, são entidades a que a lei empresta personalidade, isto é, são seres que atuam na vida jurídica, com personalidade diversa da dos indivíduos que os compõem, capazes de serem sujeitos de direitos e obrigações na ordem civil".

19 Instituições de Direito Civil - Introdução ao Direito Civil - Teoria Geral de Direito Civil, vol. I, $22^{\mathrm{a}}$ ed. atualizada por Maria Celina Bodin de Moraes, Rio de Janeiro, Forense, 2007, pp. 297 e 298 :

"Todo homem é dotado de capacidade de adquirir direitos. Todo homem é sujeito da relação juídica. Mas não é somente a ele que o ordenamento legal reconhece esta faculdade. (...) Mas a complexidade da vida civil e a necessidade da conjugação de esforços de vários indivíduos para a consecução de objetivos comuns ou de interesse social, ao mesmo passo que aconselham e estimulam a sua agregação e polarização de suas atividades, sugerem ao direito equiparar à própria pessoa humana certos agrupamentos de indivíduos e certas destinações patrimoniais e lhe aconselham atribuir personalidade e capacidade de ação aos entes abstratos assim gerados. Surgem, então, as pessoas jurídicas, que se compõem, ora de um conjunto de pessoas, ora de uma destinação patrimonial, com aptidão para adquirir e exercer direitos e contrair obrigações.

(..)

O sentimento gregário do homem permite afirmar que a associação é inerente à sua natureza, corrigindolhe as fraquezas e suprindo com a sua continuidade a brevidade da vida. $\mathrm{O}$ espírito criador engendra então entidades coletivas, resultantes de um agregado de pessoas ou de um acervo de bens, por via dos quais logra a obtenção de resultados mais positivos e mais amplos do que consegue o esforço individual isolado. A possibilidade de mobilizar capitais mais vultosos, a necessidade de reunir para uma finalidade única atividades mais numerosas e especializadas do que o indivíduo isolado pode desenvolver, a continuidade de esforços através de órgãos que não envelhecem - tudo sugere a criação e a proliferação desses entes, (...)". 
nasce tão somente da reunião de grupo de pessoas, mas é necessário que haja unidade orgânica que justamente a distinga de seus menbros ${ }^{20}$.

\subsubsection{Enfoque Histórico}

Por fim, cabe rememorar que a atual concepção da pessoa jurídica é fruto do amálgama dos direitos romano, germânico e canônico. O conceito surge da evolução do princípio da unidade para o da universalidade, o que no direito romano se deu com a constituição dos municipia, que se regiam pelo direito privado e eram dotados de patrimônio, o qual não era, por assim dizer, condomínio dos seus membros componentes. No direito germânico, a transposição demorou muito e se deu sob influência dos romanos, uma vez que davam preferência ao conceito de sociedade em detrimento do de pessoa jurídica. E o direito canônico absorveu bem a idéia, uma vez que todos os seus institutos eram reputados entidades autônomas e produto da Obra de Deus. Tudo isso, por meio dos estudos da pandectística alemã, acaba por lançar as bases da atual concepção de pessoa jurídica $^{21}$.

20 Instituições de Direito Civil - Introdução ao Direito Civil - Teoria Geral de Direito Civil, vol. I, 22ª ed. atualizada por Maria Celina Bodin de Moraes, Rio de Janeiro, Forense, 2007, p. 298:

"Não basta, entretanto, que alguns indivíduos se reúnam, para que tenha nascimento a personalidade jurídica do grupo. É preciso que, além do fato externo da sua aglomeração, se estabeleça uma vinculação jurídica específica, que lhe imprima unidade orgânica. Em virtude desta unidade, como fator psíquico de sua constituição, assume a entidade criada um sentido existencial que a distingue dos elementos componentes, o que já fora pela agudeza romana assinalado, quando dizia que 'societas distat a singulis'. Numa associação vê-se um conjunto de pessoas, unindo seus esforços e dirigindo suas vontades para a realização dos fins comuns. Mas a personificação do ente abstrato destaca a vontade coletiva do grupo, das vontades individuais dos participantes, de tal forma que o seu querer é uma 'resultante' e não mera justaposição das manifestações volitivas isoladas".

21 M. M. de SeRpa Lopes, Curso de Direito Civil - Introdução, Parte Geral e Teoria dos Negócios Jurídicos, vol. 1, $6^{\text {a }}$ ed. atualizada por José Serpa Santa Maria, Rio de Janeiro, Freitas Bastos, 1988, pp. 312 e 313 :

"As concepções romana e canônica surgiram, assim, aproximadas por esse ponto comum - o revestimento unitário da pluralidade, uma entidade autônoma em relação aos seus membros competentes, divergindo a concepção canônica apenas quanto à idéia de instituição, o instituto, com a sua tendência para nela absorver todas as formas associativas e imprimir um caráter especial, a todas as pessoas jurídicas. Enquanto isso a concepção germânica atuava com uma direção oposta.

Foram essas três correntes as orientadoras do Direito Medieval e da doutrina dos glosadores, os quais, porém, se apegaram à idéia germânica, apesar de adotarem o conceito romano de universitas.

Os canonistas, ao contrário, insistiram no tema institucional, de que se fez paladino o insigne Sinibaldo dei Fieschi, mais tarde o papa Inocêncio IV, doutrina que se converteu na do Direito comum, posteriormente reelaborada pela ciência jurídica, e, em especial, pelos pandectistas alemães, sob cujos auspícios foram lançados os germes das modernas teorias da personalidade jurídica”. 


\subsubsection{Enfoque da Defesa Patrimonial}

Com estribo no magistério de Rui Geraldo CAMARGO VIANA ${ }^{22}$, adota-se nesse trabalho a definição que enfoca o escopo de proteção ao patrimônio pessoal, invariavelmente, perseguido pelos idealizadores ou instituidores de uma pessoa jurídica. Nessa medida, "a pessoa jurídica é uma elucubração da mente do homem, que a fim de defender o seu patrimônio, cria um ente à sua imagem e semelhança”.

Em certa medida, essa definição se aproxima da de Orlando GOMES ${ }^{23}$, embora não no tocante ao seu núcleo, calcado na proteção patrimonial.

\subsection{A Pessoa Jurídica no Direito Romano}

O estudo sistemático e moderno do direito romano, entendido como o plexo de normas jurídicas que regeram a vida dos habitantes de Roma e das demias localidades sobre seu domínio ${ }^{24}$, divide-o em três fases ou períodos, conforme a sua evolução histórica: direito pré-clássico, clássico e pós-clássico ${ }^{25}$.

22 A definição do Professor Rui Geraldo CAmargo Viana, Titular de Direito Civil da Faculdade de Direito da Universidade de São Paulo, não se encontra, ainda, publicada, embora sempre repristinada em suas aulas na Academia de Direito.

23 Introdução ao Direito Civil, $19^{\mathrm{a}}$ ed. atualizada por Edivaldo Brito e Reginalda Paranhos de Brito, Rio de Janeiro, Forense, 2007, p. 167:

"Não são apenas as pessoas naturais que podem ser sujeito de direito. Entes formados pelo agrupamento de homens, para fins determinados, adquirem personalidades distintas dos seus componentes. Reconhece-lhes a lei capacidade de ter direitos e contrair obrigações.

A personalização desses grupos é construção técnica destinada a possibilitar e favorecer-lhes a atividade. O Direito toma-os da sociedade, onde se formam, e os disciplina à imagem e semelhança das pessoas naturais, reconhecendo-os como pessoas, cuja existência autônoma submete a requisitos necessários a que possam exercer direitos, dando-lhes regime compatível com a sua natureza".

24 A. CORRÊA - G. SCIASCIA, Manual de Direito Romano, 6a ed., São Paulo, RT, 1988, p. 13:

"Chama-se direito romano ao conjunto de normas jurídicas que vigoraram em Roma e nos países regidos pelos romanos.

Da data da fundação da cidade aos nossos dias, várias vicissitudes históricas, sociais e políticas, ocasionaram a recepção da parte do direito romano, que regula as relações dos indivíduos entre si (direito privado romano), pelos sistemas jurídicos dos países modernos. Em muitos dêstes o direito romano foi acolhido tão amplamaente, de maneira a autorizar a denominação de países com sistema jurídico de base romanística, como, por exemplo, quase todos os da Europa continental, da América Latina e até mesmo do Extremo Oriente, como o Japão. (...)

Tendo-se presente a história de Portugal e sua colonização, torna-se evidente a razão por que o Brasil segue o sistema jurídico romano. A civilização dos povos fenícios, celtas, gregos, cartagineses, na Península Ibérica, quase desapareceu em contato com a dos romanos, que, após a destruição de Cartago, em 146 antes de cristo, atraíram todos êsses povos para órbita da sua civitas, tornando-os com o tempo cidadãos romanos. A invasão dos gôdos e visigodos, após a queda do Império Romano (476 d.C.), não podia alterar profundamente uma civilização superior; e mais tarde o domínio dos árabes (711 até 1492) não se impôs de modo definitivo sobre os povos latinos".

25 T. MARKY, Curso Elementar de Direito Romano, $8^{\mathrm{a}}$ ed., São Paulo, Saraiva, 1995, pp. 5 e 6 : 
É possível ainda separar a evolução do direito romano ao longo dos seus treze séculos conforme as mudanças na conformação do Estado Romano ou de acordo com as alterações internas do próprio direito privado, sendo que sob este último aspecto também distinguem-se três períodos: período do direito quiritário, período do ius gentium, este com duas fases, e o período pós-clássico ${ }^{26}$.

Inicialmente é preciso alertar que os romanos, cujo espírito era avesso às abstrações, não cuidaram de elaborar uma doutrina ou teoria sobre a pessoa jurídica, não dispondo nem mesmo de um termo genérico para designar estes sujeitos de direito, sendo

"Outra divisão, talvez preferível didaticamente, distingue no estudo do direito romano, tendo em conta sua evolução interna: o período arcaico (da fundação de Roma no século VIII a.C. até o século II a.C.), o período clássico (até o século III d. C.) e o período pós-clássico (até o século VI d. C.)”.

26 A. CorrêA - G. SCIASCIA, Manual de Direito Romano, 6 ed., São Paulo, RT, 1988, pp. 15 a 17:

"Para comodidade didática e utilidade científica, nos treze séculos de vida do direito romano, que consideramos, costumam distinguir-se vários períodos. A distinção em períodos pode basear-se ou em mudanças da constituição do Estado Romano ou na modificação interna do direito privado, em conseqüência de acontecimentos de grande importância.

(...)

B) No que concerne à evolução interna do direito romano é preferível que se lhe distingam as fases seguintes:

(I) Período do direito quiritário (ius Quiritium, ius civile), desde a fundação de Roma até a Codificação da Lei das XII Tábuas. O caráter lendário dêste período e a falta de elementos autênticos não permitem uma reconstrução histórica certa. O direito está na primeira fase de seu desenvolvimento; vige o direito nacional romano, exclusivo dos cidadãos, formalístico, rigoroso, adaptado só a um povo de economia familiar e agrária, que constitui uma pequena comuna rústica com raras e esporádicas relações pacíficas com as comunas estrangeiras.

(II) O período do ius gentium no qual convém distinguir ulteriormente as seguintes fases:

a) Depois das guerras púnicas, vitoriosamente levadas a cabo contra os cartagineses no II século a. C., Roma se afirma como grande centro comercial, para onde afluem povos dos territórios conquistados. A economia patriarcal transforma-se em economia de tipo capitalista. Impera o jus gentium, i. é, o direito comum a todos os povos do Mediterrâneo, fundado sôbre o bonum et aequum - a boa fé: o direito universal que se aplica a todos os homens livres. Em virtude da ação do pretor, magistrado que administra a justiça, se constrói um sistema jurídico magistral (jus honorarium), que auxilia, supre, emenda com elasticidade o tronco originário do jus Quiritium.

b) Nos últimos anos da República começa o período áureo do direito romano, i. é, o do direito clássico, que vai até a época dos últimos jurisconsultos clássicos, contemporâneos de Alexandre Severo (222-235 d. C.). O direito recebe profunda eleboração científica dos jurisconsultos que o analisam nos seus diversos elementos. Depois da consolidadção do imperador Adriano, o direito adquire nôvo impulso pelo fato de a administração da justiça ter sido assumida diretamente pelo imperador e seus funcionários (cognitio extra ordinem).

(III) O período pós-clássico que começa com Diocleciano e se encerra com o direito justinianeu. A decadência política dêste período não corresponde, em certo sentido, à decadência jurídica. Se é verdade que faltam grandes jurisconsultos e os mestres do direito procuram simplificar a produção dos juristas clássicos, é também indiscutível que o direito romano contém em si a qualidade de se adptar aos novos princípios sociais afirmados pelo Cristianismo, que entram como os fatôres mais importantes na natural transformação do direito. Os vários sistemas jurídicos do ius civile, do ius gentium, do ius honorarium, da cognitio extra ordinem se fundem num único corpo de direito. Nêste período se forma em definitivo o direito moderno, codificado no VI ${ }^{\circ}$ século pelo imperador Justiniano". 
que se extrai da fontes tão somente princípios generalizados que conformam os alicerces da moderna disciplina dos entes abstratos ${ }^{27},{ }^{28}$.

O período do direito romano pré-clássico não conheceu o fenômeno da pessoa jurídica como ente abstrato e sujeito de direitos e obrigações, distinto das pessoas naturais ${ }^{29},{ }^{30}$, sendo que nesse período até mesmo os bens públicos eram considerados de todos ou de ninguém e os bens, por exemplo, das corporações, eram reputados copropriedade de cada um dos indivíduos que a compunham.

É no direito clássico que surge a idéia de paralelamente ao homem existirem, também, entes abstratos, da mesma forma, titulares de direitos e obrigações na ordem civil, mas que não se confundem com os elementos que os compõem ${ }^{31}$. Essa primeira noção

27 J. C. Moreira Alves, Direito Romano, vol. 1, $13^{\mathrm{a}}$ ed., Rio de Janeiro, Forense, 2003, p. 132:

“(...) não sem antes salientar que os juristas romanos não elaboraram (como, em geral, não o faziam, por não serem dados a abstrações) uma teoria sobre a pessoa jurídica. No entanto, dos textos podem extrairse os princípios que, ali, vigoraram para a disciplina dessas entidades abstratas".

28 A. CORRÊA - G. SCIASCIA, Manual de Direito Romano, $6^{\text {a }}$ ed., São Paulo, RT, 1988, p. 46:

"Os romanos não têm têrmo genérico para designar tais sujeitos de direito, e nem mesmo construíram uma doutrina dos entes morais, cientificamente organizada. Mas nesta matéria as fontes enunciam princípios que, generalizados, constituem as bases da teoria moderna".

29 J. C. MoreIRA Alves, Direito Romano, vol. 1, $13^{\mathrm{a}}$ ed., Rio de Janeiro, Forense, 2003, p. 132:

"No direito pré-clássico, não encontramos, em Roma, a idéia de que entes abstratos possam ser titulares de direitos subjetivos à semelhança das pessoas físicas. Aliás, o nascimento dessa concepção demanda processo evolutivo lento, cujo ponto de partida exigia capacidade de abstração ainda não existente em época primitiva.

Os romanos, nesse período, entendiam que, quando um patrimônio pertencia a várias pessoas, o titular dele não era uma entidade abstrata - a corporação -, mas, sim, os diferentes indivíduos que constituíam o conjunto, cada um titular de parcela dos bens. (...)".

30 F. C. Pontes de Miranda,. Tratado de Direito Privado - Parte Geral - Tomo I - Introdução. Pessoas Físicas e Jurídicas, $4^{\text {a }}$ ed., São Paulo, RT, 1974, pp. 283 e 284:

“(...) O antigo direito romano desconhecia o conceito de pessoa jurídica: o ius privatum (ius civile) só tocava a pessoas físicas, aos civis. Os collegia e as solidates não eram pessoas. A res publica era o bem do povo romano; e êsse não era pessoa privada. Coisa do povo era extra comercium. A própria terra do povo, ager publicus, não pertencia a ninguém. Lá está em GAIO (L. 1, pr. D., de divisione rerum et qualitate, 1, 8): "quae publicae sunt, nullius in bonis esse creduntur, ipsius enim universitatis esse creduntur". Nullius, de ninguém. O próprio ius para os negócios jurídicos era publicum, e não privatum. Quando a res publica teve de entrar em comércio, privatizou-se. A evolução começou pelo municipium, que passou a ser pessoa, no direito privado; depois, personificaram-se collegia, solidates e universitates. Com a distinção entre fiscus Caesaris e aerarium populi Roamanum, aquêle entrou no rol das pessoas de direito privado (cf. L. MitTEIS, Römisches Privatrecht, I. 349 s.). A pessoa jurídica exsurgiu, portanto, em sua estrutura característica, no Império. Por isso mesmo, tôda teoria que negou, ou nega, a existência de pessoa jurídica, no direito contemporâneo, contra as regras jurídicas positivas e a concepção mesma que está à base dos sistemas jurídicos, constitui regressão psíquica à idade pré-imperial, desconhece a evolução que se operou até se terem os bens municipais como bens pertencentes ao corpus, em vez de pertencentes a todos ou a ninguém ( $\mathrm{Si}$ quid universiti debetur, singulis non debetur, nec quod debet universitas singuli debent, L. 7, § 1, D., quod cuiusque universitatis nomine vel contra eam agatur, 3, 4)".

31 A. CORRÊA - G. SCIASCIA, Manual de Direito Romano, 6a ed., São Paulo, RT, 1988, pp. 46 e 47:

"Característica essencial do ente moral é a sua unidade e a independência dos elementos que o compõem. Portanto: - Si quid universitati debentur, singulis non debentur: Nec quod debet universitas, singuli 
surge no âmbito do direito público, com o reconhecimento do Estado Romano - populus romanus - como ente distinto do conjunto dos cidadãos, embora impassível de relações jurídicas na órbita civil, mas tão-somente na seara do direito público. Desse ponto de partida, o direito clássico estende a titularidade de direitos subjetivos às ciuitates e aos municipia. Estes, diferentemente do populus romanus e das ciuitates - cidades estrangeiras anexadas ao Império Romano que conservavam parte de sua soberania e, por conseguinte, regiam-se pelo direito público -, eram comunidades também agregadas a Roma, porém sem nenhum resquício de soberania, regendo-se, por assim dizer, pelo direito privado. É, portando, dos municipia que surge a primeira noção de pessoa jurídica no âmbito do direito privado em Roma ${ }^{32}$.

Assim, abstraindo-se o Populus Romanus, ente de direito público, percebe-se que, neste primeiro momento no direito clássico, reconhecem-se na órbita do direito privado basicamente as corporações, ou seja, as uniuersitas personarum, além dos municipia, das

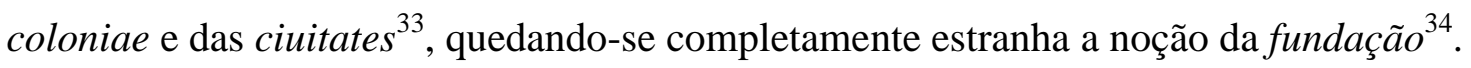

debent. A lei reconhece, de forma geral ou em cada caso determinado, a qualidade de sujeitos de direito a tais entes".

32 J. C. Moreira Alves, Direito Romano, vol. 1, 13 a ed., Rio de Janeiro, Forense, 2003, p. 133:

"Chegou-se à idéia de corporação graças ao resultado de uma evolução que se inicia no momento em que, já no direito clássico, os romanos passam a encarar o Estado como entidade abstrata diversa do conjunto de seus cidadãos. A denominação técnica que os textos dão ao Estado, como pessoa, é populus romanus. Mas, para os romanos, o Estado jamais entra em relação com os particulares em plano de igualdade. As relações jurídicas de que participa o Estado são - porque é ele soberano - sempre disciplinadas pelo direito público, e não pelo direito privado. Assim, em Roma, o particular não pode demandar o Estado em processo judicial comum, mas aquele dispõe apenas de recursos administrativos contra as decisões deste. Mesmo celebrando um contrato, o Estado está em posição de superioridade à do indivíduo que com ele contrata. Portanto, embora os romanos vejam no Estado um ser abstrato distinto de seus cidadãos, não se pode considerar que seja essa a origem da concepção de pessoa jurídica de direito privado. Mas esse foi, sem dúvida, o passo inicial.

A exemplo do Estado, admitiu-se, no direito clássico, que as ciuitates e os municipia fossem capazes de ser titulares de direitos subjetivos. E o mesmo ocorreu com as coloniae no principado, quando desapareceu a distinção entre municípios e colônias. No entanto, até 212 d.C., as ciutates eram cidades estrangeiras que tinham sido anexadas ao Império Romano sem perderem totalmente a sua soberania, razão por que, à semelhança do que sucedia com o Estado Romano, suas relações eram regidas sempre pelo direito público. Já com referência aos municípios (comunidades agregadas às tribos de Roma, e que, portanto, tinham perdido sua soberania), as relações jurídicas de que eles participavam eram disciplinadas pelo direito privado.Ora, regendo-se os municípios, no campo patrimonial, pelo direito privado, e sendo encarados - como o Estado Romano e as ciuitates - como seres abstratos, distintos das pessoas físicas que os compunham, capazes de ter direitos, surgiu daí a concepção de pessoa jurídica no direito privado romano, estendendo-se, depois, a certas associações voluntárias de pessoas físicas que visavam a determinado fim, e que desde tempos remotos existiam em Roma com as denominações collegia e uniuersitates, e com escopo funerário, religioso ou comercial”.

33 A. CORRÊA - G. SCIASCIA, Manual de Direito Romano, $6^{a}$ ed., São Paulo, RT, 1988, p. 47:

"Fazendo abstração do populus Romanus, a máxima organização dos homens livres cidadãos-romanos, cuja unidade e cuja esfera de ação embora interessado sobretudo o direito público, não deixou contudo de exercer a sua influência sobre a doutrina privada, as pessoas jurídicas reconhecidas em Roma são as seguintes: 
Há dissensso entre os romanistas se a noção de fundação como pessoa jurídica foi conhecida dos romanos mesmo no período pós-clássico ${ }^{35}$. Parte deles identificam certos entes unitários, ou seja, universalidades de bens destinados a cumprir um objetivo determinado, com as fundações, enumerando as instituições de beneficência (piae causae) e o Fisco (fiscus Caesaris), sendo este o tesouro particular do princeps, distinguindo-se, num primeiro momento, do Erário (aerarium populi Romani) ${ }^{36}$.

Os collegia, chamados também universitates, societates, sodalitates, corpora, são corporações, i é, associações de pessoas com um escopo comum. Conhecem-se vários tipos de collegia: associaçãoes com fins religiosos, corporações de artes e ofícios, sociedades com fins esportivos e com fins lucrativos, como p. ex., as societates publicanorum, para arrecadação de impostos, corpora aurifodinarum vel argentifodinarum vel salinarum para exploração de minas de ouro, prata, sal. Cada collegium tem um estatuto (lex collegii) e órgãos que agem por êle (actor, syndicus). Nas fontes justinianéias se afirma: Neratius Priscus tres facere existimat collegium, et hoc magis sequendum est.; porém, um vez constituído: - si universitas ad unum redit magis admittitur posse eum convenire et conveniri, cum ius omnium in unum recciderit et stet nomen universitatis.

Os municipia, as coloniae, as civitates são igualmente corporações de direito privado: - civitates enim privatorum loco habentur. Podem ser proprietários adquirir bens por legado e fideicomisso, e em época tardia ser também instituídos herdeiros".

34 J. C. MOREIRA Alves, Direito Romano, vol. 1, 13ª ed., Rio de Janeiro, Forense, 2003, p. 133:

"No direito clássico, surge a concepção de que ao lado do homem como pesoa física, há certas entidades abstratas que são, também, titulares do direito subjetivo. Mas, nesse período, não se vai além do reconhecimento da existência das corporações. É estranho ao direito clássico o conceito de fundação".

35 J. C. MoreIRA Alves, Direito Romano, vol. 1, $13^{\mathrm{a}}$ ed., Rio de Janeiro, Forense, 2003, p. 134:

"Quanto ao direito pós-clássico, vários romanistas vislumbram a existência de verdadeiras fundações nas piae causae (bens destinados a fins beneficentes ou religiosos), na herança jacente (herança que jaz à espera de aceitação de um herdeiro) e no Fisco (no principado, era o tesouro particular do princeps, em contraposição ao aerarium, o patrimônio do Estado; no dominato, o Fisco passa a ser o único tesouro do Estado).

A maioria dos autores, no entanto, entende que, embora no tempo de Justiniano haja tendência no sentido de se considerarem esses institutos como entidades dotadas de personalidade jurídica, os textos não fornecem elementos inequívocos para que se afirme que as fundações, como pessoas jurídicas, foram conhecidas dos romanos".

36 A. CORRÊA - G. SCIASCIA, Manual de Direito Romano, 6a ed., São Paulo, RT, 1988, pp. 47 e 48 :

"Sòmente no direito pós-clássico se reconheceram entes unitários semelhantes à fundações, i. é, constituídos por um complexo de bens destinados a um escopo determinado. Entre tais entes se enumeram sobretudo as instituições de beneficência (piae causae), que se multiplicaram por influência do Cristianismo: - ptocotrophia, para os pobres; gerontocomia, para os velhos; xenodochia, para os peregrinos. O seu escopo teve caráter perpétuo; o bispo é o legítimo representante dos interêsses e das funções sociais que o ente visa. Tais entes podem ser herdeiros e réus em juízo. É discutível se o fiscus Caesaris, i é, a caixa, o tesouro do Estado administrado pelo imperador, originàriamente o aerarium populi Romani, constituía um sujeito de direito unitário.

Alguns textos assimilam certos complexos patrimoniais ao homem; assim Justiniano reconheceu a qualidade de ente moral à herança jacente, que por direito romano era o patrimônio de uma pessoa morta e que ainda não fôra aceito pelo herdeiro. Em relação à herança se diz: hereditas personae vice fungitur; hereditas defuncti personam sustinet. A respeito do peculium se afirma que êste patrimônio é semelhante a um homem. Cumpre porém ter bem presente que um complexo patrimonial pode ser considerado unitàriamente, não como sujeito de direitos e obrigações, i é, como pessoa, mas como objeto de relações jurídicas, i é, como coisa. O pecúlio, o dote, o patrimônio do falido devem de preferência considerar-se como tais; assim, a herança, como objeto de direitos constitui um coisa universal". 


\subsection{Os Requisitos da Pessoa Jurídica}

No direito romano, as corporações tinham como requisitos para sua constituição a presença de pelo menos três pessoas naturais para se associarem; o estatuto, denominado lex collegii ou lex municipii, o qual regulava sua organização e funcionamento; e que sua finalidade fosse lícita ${ }^{37}$. E se discute entre os romanistas se a estes requisitos se somava mais um, a autorização prévia do Estado Romano, sendo certo que a Lei das XII Tábuas não consagrava essa exigência, que somente mais tarde, por razões de polícia, a Lex Iulia de collegiis, para que se reputasse lícita determinada corporação, passou a demandar a autorização estatal acerca de sua constituição ${ }^{38}$.

O direito moderno não se afasta da noção do Direito Romano. São, hoje, apontados, também, três requisitos para a constituição de uma pessoa jurídica ${ }^{39}$ de direito privado ${ }^{40}$.

37 J. C. MoreIRA Alves, Direito Romano, vol. 1, 13 a ed., Rio de Janeiro, Forense, 2003, pp. 134 e 135 :

"São várias as denominações usadas pelos juristas romanos para designar as corporações ou associações: sodalitas, sodalicium, ordo, societas, collegium, corpus, uniuersitas. Por onde se observa que não havia, a respeito, nomeclatura técnica uniforme.

Os requisitos para a constituição da corporação eram os seguintes:

a) que, no momento de sua constituição, houvesse, pelo menos, três pessoas para se associarem;

b) estatuto - denominado, nas fontes, lex collegii ou lex municipii - onde se regulasse sua organização e funcionamento; e

c) que sua finalidade - assim, por exemplo, religiosa, política, comercial - fosse lícita”.

38 J. C. MoreIRA Alves, Direito Romano, vol. 1, $13^{\mathrm{a}}$ ed., Rio de Janeiro, Forense, 2003, p. 135:

"Discutem os autores modernos se, além desses três requisitos, seria necessário um quarto: a autorização prévia do Estado para que se atribuísse personalidade jurídica à corporação; ou se, ao contrário, a personalidade jurídica surgia apenas com o preenchimento daqueles três requisitos. Segundo parece, os romanos não exigiam essa autorização prévia do Estado para que a corporação adquirisse personalidade jurídica; mas, por motivos de polícia, para que se reputasse lícita uma associação, em geral era preciso (e isso a partir de uma lex Iulia de colegiis, do tempo de Júlio César ou de Augusto) que o Estado, decidindo sobre a licitude de sua finalidade, autorizasse a constituição dela. Com isso, alterou-se o sistema que tinha sido consagrado pela Lei das XII Tábuas, que não exigia qualquer espécie de autorização estatal".

39 Caio Mário da Silva PereIRA, Instituições de Direito Civil - Introdução ao Direito Civil - Teoria Geral de Direito Civil, vol. I, $22^{\mathrm{a}}$ ed. atualizada por Maria Celina Bodin de Moraes, Rio de Janeiro, Forense, 2007, p. 298:

"Para a constituição ou o nascimento da pessoa jurídica é necessária a conjunção de três requisitos: a vontade humana criadora, a observância das condições legais de sua formação e a liceidade de seus propósitos".

40 As pessoas jurídicas de direito público têm sua origem, fundamentalmente, na lei, em sentido largo, podendo se revestir de Constituição, Lei Orgânica, Lei Complementar ou Ordinária, dependendo da espécie. O Estado Soberano, ao seu turno, tem origem mais complexa, fruto, por exemplo, para os que advogam a Teoria Contratualista, de um grande contrato social celebrado entre os seus cidadãos, sendo seus elementos clássicos o povo, o território e o poder ou soberania. Nesse sentido:

Manoel Gonçalves FerreIRA FILHO, Curso de Direito Constitucioanal, 19ª ed., São Paulo, Saraiva, 1992, pp. 39 e 40:

"Segundo ensina a doutrina tradicional, o Estado é uma associação humana (povo), radicada em base espacial (território), que vive sob o comando de uma autoridade (poder) não sujeita a qualquer outra (soberana).

Mais sutil é a lição de Kelsen (v. Teoria pura do direito), ao mostrar que o Estado e seus elementos povo, território e poder - só podem ser caracterizados juridicamente. 
O primeiro é a vontade humana criadora ou a vontade de constituí-la com soma de esforços e perseguição de objetivos comuns ${ }^{41}$. Nesse ponto, frise-se, para o direito atual já temos uma pessoa jurídica, mesmo que ainda de fato ou irregular. Sílvio RodRIGUES ${ }^{42}$ alerta para a distinção entre a existência no plano do direito e no plano dos fatos, lembrando que o Código Civil $^{43}$, ao estipular que a existência legal da pessoa jurídica começa com inscrição dos seus atos constitutivos no pertinente registro público, reconhece a existência anterior, no plano puramente material, de uma organização subjacente de um conjunto de pessoas buscando objetivo comum ou de um patrimônio cindido para determinada destinação específica.

De fato, a coletividade que é o povo decorre de critérios que são fixados pela ordem jurídica estatal. É ela formada por quem o direito estatal reconhece como integrante da dimensão pessoal do Estado. Pertence, pois, ao povo quem o direito do Estado assim declara (...).

Território, a seu turno, é o domínio espacial de vigência de uma ordem jurídica estatal. É também por ela definido, tanto no tocante às terras como às águas, tanto no concernente às profundezas quanto às alturas. (...)

Poder, enfim. Este se traduz no cumprimento das normas estatais. Só existe poder quando tem ele efetividade ou eficácia, quando globalemnte os seus comandos são obedecidos.

(...)

Por outro lado, essa ordem que é o Estado não está subordinada a outra ordem estatal. É ela soberana.

(...)".

41 Caio Mário da Silva Pereira, Instituições de Direito Civil - Introdução ao Direito Civil - Teoria Geral de Direito Civil, vol. I, $22^{\mathrm{a}}$ ed. atualizada por Maria Celina Bodin de Moraes, Rio de Janeiro, Forense, 2007, pp. 298 e 299:

"Quando duas ou mais pessoas se congregam e desenvolvem as suas atividades ou reúnem os seus esforços, trabalhando em companhia ou conjugando suas aptidões para o mesmo fim, nem por isso dão nascimento a uma entidade personificada. Freqüentemente indivíduos labutam de parceria. Mas não nasce daí uma personalidade jurídica autônoma. Para que isto ocorra é mister a conversão das vontades dos participantes do grupo na direção integrativa deste em um organismo. Por outro lado, um indivíduo pode destacar bens de seu patrimônio para atividade filantrópica ou por qualquer motivo relevante e socialmente útil, sem a criação de entidade personificada. Para que a destinação patrimonial se converta em uma pessoa jurídica é necessária a intercorrência de uma expressão volitiva especificamente dirigida a este fim e, então, diz-se que a vontade aqui é heterônoma. Isto é, determinada pelo fundador. Sempre, pois, a pessoa jurídica como tal tem sua gênese na vontade humana, vontade eminentemente criadora que, para ser eficaz, deve emitir-se na conformidade do que prescreve o direito positivo".

42 Sílvio Rodrigues, Direito Civil - Parte Geral, vol. 1, $34^{a}$ ed., São Paulo, Saraiva, 2007, p. 91:

"A existência, perante a lei, das pessoas jurídicas de direito privado começa com a inscrição dos seus contratos, atos constitutivos, estatuos ou compromissos em seu registro público peculiar.

Note-se, desde logo, a distinção entre existência no plano do direito e a existência no plano dos fatos. Se a lei declara que a existência no plano do direito se inicia com a inscrição dos estatutos no registro peculiar, é porque, naturalmente, admite que exista no campo material uma organização subjacente, representada por um agrupamento de pessoas buscando um fim comum, ou por um patrimônio separado, voltado a determinada destinação. Portanto, a compor a idéia de pessoa jurídica encontram-se dois elementos: o material, representado quer pela associação de pessoas (preexistente), quer por um patrimônio destinado a um fim, e o jurídico, constante da atribuição de personalidade, que decorre de uma determinação da lei, e cuja eficácia advém dos estatutos no registro peculiar".

43 "Art. 45. Começa a existência legal das pessoas jurídicas de direito privado com a inscrição do ato constitutivo no respectivo registro, precedida, quando necessário, de autorização ou aprovação do Poder Executivo, averbando-se no registro todas as alterações por que passar o ato constitutivo.

(...)". 
O requisito seguinte é a obediência ao império da lei, a qual ditará regras que observadas darão à pessoa jurídica nascente o caráter de regularidade. Aqui, como hoje existe uma gama muito grande de espécies de pessoa jurídica, impõe-se, por conseguinte, grande variedade de exigências para sua regularidade. $\mathrm{O}$ requisito fundamental exigido pela lei civil é o registro dos atos constitutivos, que faz com que o ordenamento jurídico reconheça a existência da pessoa jurídica e a repute titular de direitos na órbita jurídica, portanto pessoa ${ }^{44}$.

Note-se, porém, que, no âmbito do Direito de Empresa, o Código Civil reconhece e disciplina, ao lado das Sociedades Personificadas, duas modalidades de Sociedades Não Personificadas, que podem ter natureza civil ou empresarial. A Sociedade em Comum $^{45}$ é qualquer das espécies de sociedade até que providencie o competente registro de seus atos constitutivos e a Sociedade em Conta de Participação ${ }^{46}$ define-se, legalmente, pelo

44 Caio Mário da Silva PereIRA, Instituições de Direito Civil - Introdução ao Direito Civil - Teoria Geral de Direito Civil, vol. I, 22 ${ }^{\mathrm{a}}$ ed. atualizada por Maria Celina Bodin de Moraes, Rio de Janeiro, Forense, 2007, p. 299:

"O segundo requisito está na observância das prescrições legais relativas à sua constituição. É a lei que determina a forma a que obedece aquela declaração de vontade, franqueando aos indivíduos a adoção de instrumento particular ou exigindo o escrito público. É a lei que institui a necessidade de prévia autorização do Poder Executivo para certas categorias de entidades funcionarem. É ainda a lei que estipula a inscrição do ato ocnstitutivo no Registro Público como condição de aquisição da personalidade. É a lei, em suma, que preside à conversão formal de um aglomerado de pessoas naturais em uma só pessoa jurídica”.

45 Código Civil:

“Art. 986. Enquanto não inscritos os atos constitutivos, reger-se-á a sociedade, exceto por ações em organização, pelo disposto neste Capítulo, observadas, subsidiariamente e no que com ele forem compatíveis, as normas da sociedade simples.

Art. 987. Os sócios, nas relações entre si ou com terceiros, somente por escrito podem provar a existência da sociedade, mas os terceiros podem prová-la de qualquer modo.

Art. 988. Os bens e dívidas sociais constituem patrimônio especial, do qual os sócios são titulares em comum.

Art. 989. Os bens sociais respondem pelos atos de gestão praticados por qualquer dos sócios, salvo pacto expresso limitativo de poderes, que somente terá eficácia contra o terceiro que o conheça ou deva conhecer.

Art. 990. Todos os sócios respondem solidária e ilimitadamente pelas obrigações sociais, excluído do benefício de ordem, previsto no art. 1.024, aquele que contratou pela sociedade".

46 Código Civil:

“Art. 991. Na sociedade em conta de participação, a atividade constitutiva do objeto social é exercida unicamente pelo sócio ostensivo, em seu nome individual e sob sua própria e exclusiva responsabilidade, participando os demais dos resultados correspondentes.

Parágrafo único. Obriga-se perante terceiro tão-somente o sócio ostensivo; e, exclusivamente perante este, o sócio participante, nos termos do contrato social.

Art. 992. A constituição da sociedade em conta de participação independe de qualquer formalidade e pode provar-se por todos os meios de direito.

Art. 993. O contrato social produz efeito somente entre os sócios, e a eventual inscrição de seu instrumento em qualquer registro não confere personalidade jurídica à sociedade.

Parágrafo único. Sem prejuízo do direito de fiscalizar a gestão dos negócios sociais, o sócio participante não pode tomar parte nas relações do sócio ostensivo com terceiros, sob pena de responder solidariamente com este pelas obrigações em que intervier. 
exercício de seu objeto social por um único sócio, chamado ostensivo, em seu nome individual e por sua própria e exclusiva responsabilidade, não carecendo sua constituição e existência de qualquer formalidade ${ }^{47}$.

E, por fim, o último requisito, coincidente com o do direito romano, é o da finalidade lícita. Trata-se, em verdade, de conseqüência lógica do requisito anterior, visto que se a pessoa jurídica, assim como a pessoa natural, deve subserviência à lei, não podem seus objetivos contra ela atentar, ou seja, serem ilícitos ${ }^{48}$.

Art. 994. A contribuição do sócio participante constitui, com a do sócio ostensivo, patrimônio especial, objeto da conta de participação relativa aos negócios sociais.

$\S 1^{\circ}$ A especialização patrimonial somente produz efeitos em relação aos sócios.

$\S 2^{\circ}$ A falência do sócio ostensivo acarreta a dissolução da sociedade e a liquidação da respectiva conta, cujo saldo constituirá crédito quirografário.

$\$ 3^{\circ}$ Falindo o sócio participante, o contrato social fica sujeito às normas que regulam os efeitos da falência nos contratos bilaterais do falido.

Art. 995. Salvo estipulação em contrário, o sócio ostensivo não pode admitir novo sócio sem o consentimento expresso dos demais.

Art. 996. Aplica-se à sociedade em conta de participação, subsidiariamente e no que com ela for compatível, o disposto para a sociedade simples, e a sua liquidação rege-se pelas normas relativas à prestação de contas, na forma da lei processual.

Parágrafo único. Havendo mais de um sócio ostensivo, as respectivas contas serão prestadas e julgadas no mesmo processo".

47 Orlando GoMES, Introdução ao Direito Civil, $19^{\mathrm{a}}$ ed. atualizada por Edivaldo Brito e Reginalda Paranhos de Brito, Rio de Janeiro, Forense, 2007, p. 173:

"Em síntese, a atividade empresarial ou é desempenhada por pessoa natural ou é desempenhada por uma sociedade empresarial. Esta se classifica em dois grandes grupos: 1 - o da sociedade não personificada; 2- o da sociedade personificada.

A sociedade não personificada pode assumir as formas de sociedade em comum, assim considerada enquanto não inscritos os atos constitutivos e a sociedade em conta de participação cuja constituição independe de qualquer formalidade, provando-se sua existência por todos os meios admitidos em Direito, na qual a atividade do objeto social é exercida, unicamente, pelo sócio ostensivo, em seu nome individual e sob sua própria e exclusiva responsabilidade. Os demais sócios participam dos resultados correspondentes, a não ser que, além do seu direito de fiscalização, também, participem das relações do sócio ostensivo com terceiros porque, deste modo, responderão solidariamente. O contrato social produz efeitos somente entre os sócios e mesmo se o respectivo instrumento for inscrito em qualquer registro, esta circunstância não lhe confere personalidade jurídica.

A sociedade personificada assume diversas formas jurídicas: sociedade simples, sociedade em nome coletivo, sociedade em comandita simples, sociedade limitada, sociedade anônima ou por ações, sociedade em comandita por ações, sociedade cooperativa, sociedades coligadas".

48 Caio Mário da Silva PereIRA, Instituições de Direito Civil - Introdução ao Direito Civil - Teoria Geral de Direito Civil, vol. I, 22 ${ }^{\mathrm{a}}$ ed. atualizada por Maria Celina Bodin de Moraes, Rio de Janeiro, Forense, 2007, p. 299:

"Um terceiro requisito ainda é exigido, sem o qual não poderá haver pessoa jurídica, ainda que se agreguem pessoas naturais e se encontrem presas pelo encadeamento psíquico. Se a justificativa existencial da pessoa jurídica é a objetivação das finalidades a que visa o propósito de realizar mais eficientemente certos objetivos, a liceidade destes é imprescindível à vida do novo ente, pois não se compreende que a ordem jurídica vá franquear a formação de uma entidade, cuja existência é a projeção da vontade humana investida de poder criador pela ordem legal, a atuar e proceder em descompasso com o direito que lhe possibilittou o surgimento". 


\subsection{O Nascimento da Pessoa Jurídica}

A pessoa natural tem início biológico com o nascimento com vida, apesar de a lei ressalvar os direitos do nascituro desde a sua concepção ${ }^{49}, 50$.

Também em relação à pessoa jurídica é necessário se estabelecer o início de sua existência, que diferente da pessoa física que brota de um fato biológico, imediatamente reconhecido pelo direito, o ente moral tem seu substrato fático em um negócio jurídico que imprescinde de ser provado para ser reconhecido ${ }^{51}$.

Ainda no que concerne ao nascimento da pessoa jurídica, abre-se vasto campo de discussão, sendo necessário, antes de adentrá-lo, rememorar que o direito como fonte de satisfação de interesses pressupõe-lhe a existência de um titular e este é quem o ordenamento confere o status de pessoa e a capacidade jurídica ${ }^{52}$.

49 Código Civil:

"Art. $2^{\circ}$ - A personalidade civil da pessoa começa do nascimento com vida; mas a lei póe a salvo, desde a concepção, os direitos do nascituro".

50 Clovis Bevilaqua, Em defeza do Projecto de Codigo Civil Brazileiro, Rio de Janeiro, Francisco Alves, 1906, pp. 57-59:

"Todo ser humano, sem distinção de sexo, nacionalidade, religião ou consideração social, é considerado apto para ser sujeito de direitos e obrigações.

Em ralação ao início da existência da personalidade civil ha duas escolas. Uma faz começar a personalidade civil com o nascimento, reservando para o nascituro, entretanto, uma espectativa de direito. (...)

Outra faz coincidir a vida juridica com a vida physica, dando-lhe por extremos a concepção e a morte. (...)

Onde a verdade? Com aquelles que harmonisam o direito civil comsigo mesmo, com o penal, com a physiologia e com a logica, como demonstrou TEIXEIRA DE FREITAS a luminosa nota ao art. 221 de seu Esboço. Realmente, si o nascituro é considerado sujeito de direitos, si a lei civil lhe confere um curador, si a lei criminal o protege comminando penas contra a provocação do aborto, a logica exige que se lhe reconheça o caracter de pessoa, (...)".

51 Caio Mário da Silva PereIRA, Instituições de Direito Civil - Introdução ao Direito Civil - Teoria Geral de Direito Civil, vol. I, $22^{\mathrm{a}}$ ed. atualizada por Maria Celina Bodin de Moraes, Rio de Janeiro, Forense, 2007, p. 343:

"No trato comum da vida quotidiana, a pessoa jurídica adquire direitos e assume obrigações, entabula negócios com pessoas naturais ou com outras pessoas jurídicas. É então necessário fIxar o momento inicial de sua existência e estabelecer um meio de verificação de suas condições de funcionamento, e identificar seus órgãos de atuação.

Não fica mal um confronto entre a pessoa natural e a jurídica, pois que numa e noutra há um momento em que surge a personalidade jurídica, muito embora a primeira o receba do ordenamento legal por um fato biológico e a segunda por um ato jurídico, o que condiz ao mesmo tempo com a aquisição da personalidade e com o sistema probatório: a pessoa física recebe a personalidade do fenômeno natural do nascimento, materialemte comrpovável, e não necessita de provar que a tem; a pessoa jurídica origina-se da manifestação da vontade humana, e cumpre, a quem nisto tiver interesse, fazer a prova de que existe e preenche as condições legais de capacidade de direito. Qualquer que seja, pois, a modalidade da pessoa jurídica, e quaisquer que sejam as suas finalidades, subordina-se a sal existência à pauração de requisitos".

52 F. C. PONTES De MiRAnda, Tratado de Direito Privado - Parte Geral - Tomo I - Introdução. Pessoas Físicas e Jurídicas, $4^{\text {a }}$ ed., São Paulo, RT, 1974, p. 353: 
Desse modo, cabe indagar se a personalidade é um direito subjetivo, uma vez que a personificação nada mais é do a incidência de uma regra jurídica nesse sentido sobre um acontecimento fático, qual seja, o nascimento com vida. Ora, assim sendo não há como afastar a resposta afirmativa, ou seja, na medida que o ordenamento jurídico assegurou a capacidade jurídica a todos os homens, fixou-se o direito de personalidade a todo ser humano que nasce e negar essa conclusão é ferir direito ${ }^{53}$. Se a regra que assevera a personalidade a todos os homens e a personificação às pessoas jurídicas está esculpida no sistema jurídico que fundamenta a ordem civil, inafástavel que se trata em ambos os casos de direito subjetivo ${ }^{54}$.

Mais complexa é a análise acerca do direito à personificação da pessoa jurídica e da sua titularidade. Quanto à conclusão de se tratar a personificação - fato posterior ao suporte fático que faz nascer a pessoa jurídica, ou seja o concurso de vontades dos seus membros ou instituidores no sentido específico de criar um ente abstrato ${ }^{55}$ - também de

"O direito como poder para satisfação de interêsses, pressupõe o titular, o sujeito de direito. Quem pode ser sujeito de direito diz-se pessoa. Tal proposição pode não estar no sistema jurídico, mas claramente a formula o sistema lógico que comtemple o sistema jurídico. (...)”.

53 F. C. Pontes De MiRAnda,. Tratado de Direito Privado - Parte Geral - Tomo I - Introdução. Pessoas Físicas e Jurídicas, $4^{\text {a }}$ ed., São Paulo, RT, 1974, pp. 354 e 355:

“(...) O problema não é tão simples quando se passa à capacidade de direito, porque, aí, está elemento do suporte fáctico da personalidade e se pergunta se a personalidade é direito (= se há direito subetivo à personalidade; se há direito subjetivo a ser pessoa). O problema merece discussão. Toda personificação, ainda a dos homens, é efeito da incidência de alguma regra jurídica $\mathrm{R}$ que diga ser sujeito de direito, em dadas circuntâncias, alguém. Há suporte fático (em que estão essas circunstâncias e alguém) e a incidência da regra. A entrada dêsse ser como sujeito de direito já é efeito; a atribuição de personalidade resulta de se ver, por cima do sistema jurídico de que faz parte a regra R, que êsse ser é pessoa. Quando se diz que a capacidade de direito, a personalidade, não é direito, mal se percebe que com isso se alude a ser o efeito visto de outro sistema. Tudo isso serviria à teoria que nega qualquer direito subjetivo à personalidade se razões históricas não houvessem inserto no sistema jurídico proposições que teriam de estar no sistema por cima. Quando se aboliu a escravidão e quando se inseriram nas Constituições regras jurídicas que asseguram a capacidade de direito a todos os homens e nas leis a tutela das entidades exsurgidas, claro é que se estabeleceu direito à capacidade de direito e, pois, a ser pessoa. Se a proposição do sistema acima do sistema jurídico passa a pertencer, também, ao sistema jurídico, o fato jurídico da personificação irradia efeitos jurídicos (direitos, pretensões, ações, exceções). Todo ser humano, desde que nasce, é pessoa. Negar-lho é ferir direito; o ser humano, que nasceu, pode exigir, pode acionar, pode excepcionar, alegando ser pessoa $(=$ ter direito a ser pessoa $=$ ser contrário a direito negar-lho). (...)".

54 F. C. Pontes De MiRanda,. Tratado de Direito Privado - Parte Geral - Tomo I - Introdução. Pessoas Físicas e Jurídicas, $4^{\mathrm{a}}$ ed., São Paulo, RT, 1974, p. 355:

“(...) Temos, pois, que a personalidade é sòmente qualidade jurídica, se a regra sôbre ela apenas pertence, como enunciado do fato, ao sistema acima do sistema jurídíco, ao sistema que contempla a êsse; se a proposição foi inserta, também, no sistema jurídico, há direito subjetivo à personalidade, ou, em se tratando de pessoas jurídicas, à personificação (discutir-se-á depois sôbre quem é o titula dêsse direito) e direito adquirido, se a proposição foi inserta em ramo rígido (constitucional) do direito".

55 F. C. Pontes De MiRAndA,. Tratado de Direito Privado - Parte Geral - Tomo I - Introdução. Pessoas Físicas e Jurídicas, $4^{\mathrm{a}}$ ed., São Paulo, RT, 1974, p. 356:

"O ser humano, conceptus sed non natus, já vive, embora fora da sociedade humana. A pessoa jurídica em formação, antes, pois, de ser pessoa jurídica, - de certo modo vive, na sociedade humana, porém é a regra jurídica sôbre personificação que lhe dá a personalidade. Exatamente porque ela já está na vida 
direito subjetivo, a fundamentação é idêntica, podendo-se inclusive estabelecer analogia entre o nascituro e o ente abstrato no interregno que antecede a sua personificaçã ${ }^{56}$.

Ora, tendo-se em conta que a "existência legal" da pessoa jurídica, como ditava o velho Código de 1916 e repetiu o atual de $2002^{57}$, começa com "a inscrição do ato constitutivo no respectivo registro" e que o ato fundamental que precede, dessa forma, a personificação é a declaração de vontade dos membros ou instituidores do ente abstrato, tem-se, também, que a titularidade do direito subjetivo à personificação é, nessa medida, reservada àquelas pessoas naturais que figuram no ato constitutivo ${ }^{58}$ em que se celebrou o acordo de vontades ${ }^{59}$ e não à pessoa jurídica em fase de pré-personificação $o^{60}$. Há, portanto,

social é que precisam distinguir das que ainda não estão personificadas as já personificadas. (...) $\mathrm{O}$ concurso de vontades, como suporte fáctico, prescindiria do registro, ou de qualquer outra formalidade inicial da personificação. Não há dúvida que se poderia conceber essa personificação ipso iure; não é isso, porém, o que se passa nos diferentes sistemas jurídicos: criar-se e personificar-se são momentos diferentes. (...)"

56 F. C. Pontes De Miranda,. Tratado de Direito Privado - Parte Geral - Tomo I - Introdução. Pessoas Físicas e Jurídicas, $4^{\text {a }}$ ed., São Paulo, RT, 1974, pp. 355 e 356:

"Outra questão é a do direito à personificação. Inata no homem a personalidade, a personificação das sociedades e das fundações é posterior à sua constituição. Isso não exclui certas analogias entre o nascituro e a futura pessoa jurídica, na fase pré-personificação. Tem-se de saber se há direito à personalidade, antes da personificação, e quem é o titular dêsse direito. As teorias radicais logo respondem que não há direito à personalidade, ainda depois da personificação (e.g. A. VON TUHR, Der Allgemeine Teil, I, 455). Verdade é, porém, que os códigos inserem regras jurídicas sobre a aquisição da personalidade jurídica; e a satisfação delas cria o fato jurídico da personalidade. $\mathrm{O}$ ato, que negue a personalidade de alguma sociedade ou fundação, pode dar ensejo à ação declaratória positiva. Tanto ressalta que há relação jurídica. Por outro lado, qualquer pessoa pode ter interêsse em que se declare que a pessoa jurídica tem, ou não tem, certa capacidade de direito (cf. Constituição de 1946, arts. 153, $\$ 1^{\circ}$, 144 e 160)".

57 Caio Mário da Silva PereIRA, Instituições de Direito Civil - Introdução ao Direito Civil - Teoria Geral de Direito Civil, vol. I, 22 a ed. atualizada por Maria Celina Bodin de Moraes, Rio de Janeiro, Forense, 2007, p. 349:

"Estes princípios, fixados no Código de 1916 (arts. 18 e 19), sobreviveram no Código de 2002, tanto no que diz respeito ao começo da existência, quanto no que se refere ao conteúdo do registro (arts. 45 e 46)".

58 F. C. Pontes de MiRAnda,. Tratado de Direito Privado - Parte Geral - Tomo I - Introdução. Pessoas Físicas e Jurídicas, $4^{\mathrm{a}}$ ed., São Paulo, RT, 1974, pp. 358 e 359:

"Em sentido largo, ato constitutivo (ou instituitivo) é todo ato dos que constituem (ou instituem) a pessoa jurídica in fieri. $\mathrm{O}$ ato constitutivo não se refere à pessoa jurídica; refere-se à entidade que vai ser personificada. (...)

$\mathrm{O}$ ato constitutivo tem de ser por escrito, conter as regras fundamentais da organização, o nome e o domicilio, e especificar o fim, ou fins, e observar as regras jurídicas peculiares a cada espécie de suporte fáctico da pessoa jurídica".

59 F. C. PONTES DE MiRAndA,. Tratado de Direito Privado - Parte Geral - Tomo I - Introdução. Pessoas Físicas e Jurídicas, $4^{\mathrm{a}}$ ed., São Paulo, RT, 1974, p. 360:

"Discute-se sôbre a natureza do ato constitutivo, que é sempre declaração de vontade, pluripessoal ou, excepcionalmente, unipessoal (fundação, sociedade ou associação criada por lei). (...) Ou seja bilateral, ou plurilateral, ou unilateral, o ato constitutivo é negócio jurídico; ainda quando inserto em lei (regra jurídica criativa de pessoa jurídica), e. g., elevação de parte de Território à categoria de Estado-membro, criação de Instituto personificável ou personificado. (...)”.

60 F. C. Pontes De MiRAndA,. Tratado de Direito Privado - Parte Geral - Tomo I - Introdução. Pessoas Físicas e Jurídicas, $4^{\text {a }}$ ed., São Paulo, RT, 1974, p. 362: 
distinção, nesse tocante, entre a titularidade do direito subjetivo à personificação da pessoa física e da pessoa jurídica, sendo naquela reservada ao próprio nascituro e nesta aos figurantes do seu ato constitutivo, ou pessoa ou pessoas designadas pelo mesmo ato cosntitutivo para organização da pessoa jurídica, quando houver ${ }^{61}$.

Caio Mário da Silva PEREIRA ${ }^{62}$ informa a existência de três critérios para atribuição de personalidade às pessoas jurídicas, sendo eles o da livre formação, o do reconhecimento e o das disposições normativas. Pelo primeiro, para aquisição da personalidade basta a manisfestação de vontade dos membros ou instituidores expressada no ato constitutivo, enquanto pelo segundo exige-se a autorização confirmatória do Poder Público, remontando ao período do Direito Romano em que as corporações careciam da autorização do Estado Romano. Já o terceiro critério confere poder criador à vontade humana, porém faculta a

O ato constitutivo não dá capacidade jurídica; só a insrição a dá. Entre o ato constitutivo e a inscrição, há associação, ou sociedade, ou fundação, - não há a pessoa jurídica. Durante êsse tempo, há órgãos, inclusive o que é encarregado de promover a inscrição; a impossibilidade da inscrição só opera como condição resolutiva se os figurantes conceberam a associação, ou a sociedade, como pessoa jurídica, afastando qualquer hipótese de funcionar sem personificação".

61 F. C. Pontes De Miranda,. Tratado de Direito Privado - Parte Geral - Tomo I - Introdução. Pessoas Físicas e Jurídicas, $4^{\text {a }}$ ed., São Paulo, RT, 1974, pp. 357 e 358:

"Assente que a personalidade depende de registo (Código Civil brasileiro, art. 18), interessa saber-se qual a situação das entidades personificáveis antes da personificação (fase pré-personificação ou período constitutivo). Há, primeiro, a declaração de vontade dos membros fundadores; depois, a publicação dos estatutos, 'compromissos' ou contrato; finalmene a inscrição (Decreto n. 4.857, de 9 de novembro de 1939, arts. 129, 122-228). (...)

A pessoa jurídica nasce, de ordinário, com a inscrição: 'Começa a existência legal das pessoas jurídicas de direito privado', diz o art. 18, 'com a inscrição dos seus contratos, atos constitutivos, estatutos ou compromissos no seu registro peculiar, regulado por lei especial, ou com a autorização ou aprovação do Gôverno, quando preciso'. 'Ou' aí está por 'e'. Melhor ressalta o art. 127 e parágrafo único do Decreto n. 4.857: 'A existência legal das pessoas jurídicas só começará com o registro de seus atos constitutivos' (art. 127); 'Quando a lei exigir autorização para funcionamento da sociedade, o registro não poderá ser feito antes daquela, bem como, nas fundações, sem aprovação dos estatutos pela autoridade competente'. $\mathrm{O}$ ato constitutivo e a publicação são os dois primeiros momentos, ambos no período de prépersonificação. Os titulares de qualquer direito, pretensão, ação ou exceção, tendentes à personificação, durante esse período, são os figurantes do ato constitutivo ('contratos, atos constituivos, estatutos ou compromissos' art. 18), e não a sociedade, associação ou fundação; se, para a organização da fundação, foram designadas algumas pessoas, ou pessoa, o titular de qualquer direito, pretensão, ação, ou exceção, tendente à personificação, é quem foi designado (art. 27)".

62 Instituições de Direito Civil - Introdução ao Direito Civil - Teoria Geral de Direito Civil, vol. I, $22^{\mathrm{a}}$ ed. atualizada por Maria Celina Bodin de Moraes, Rio de Janeiro, Forense, 2007, p. 344:

"O processo genético das pessoas jurídicas de direito privado é muito diferente. Em última análise, seu fato gerador vai alojar-se na vontade humana, seja autônoma ou heterônoma, em manifestação conforme às prescrições legais. Há três critérios, que o legislador pode adotar, para atribuição de sua personalidade: o da livre formação, o do reconhecimento e o das disposições nonnativas. O primeiro admite a criação da pessoajuridica pela simples elaboração do seu ato constitutivo. A emissão de vontade dos membros componentes é o bastante para dar existência à entidade. Falho e desaconselhável, não oferece a menor segurança e estabilidade.

O sistema do reconhecimento prende suas origens no direito romano (muito embora no período republicano fossse desconhecido), desde o tempo rm que os collegia necessitavam de autorização confirmatória para atuarem. (...)". 
aquisição da personalidade à observância de determinadas condições legais, as quais cumpridas dão azo ao nascimento da pessoa jurídica ${ }^{63}$.

O direito brasileiro adota, embora não de forma pura - porque excepcionalmente é exigida autorização estatal para aquisição da personalidade - o critério das disposições normativas para criação das pessoas jurídicas ${ }^{64}$. Por este processo, dá-se ao particular plena liberdade de criação, porém se lhe exige a observância de requisitos para o reconhecimento da regularidade da pessoa jurídica.

Estabelecem-se, para tanto, duas fases, a da constituição e a do registro, nesta última nascendo o ente autônomo. A constituição, assim, como mencionado, é livre desde que se atendam aos três requisitos clássicos da manifestação da vontade humana, da obediência à lei e da finalidade lícita, e dentro desses requisitos está o registro como condição e marco do nascimento legal das pessoas jurídicas ${ }^{65}$.

63 Instituições de Direito Civil - Introdução ao Direito Civil - Teoria Geral de Direito Civil, vol. I, $22^{\mathrm{a}}$ ed. atualizada por Maria Celina Bodin de Moraes, Rio de Janeiro, Forense, 2007, p. 345:

"O terceiro critério, chamado das disposições normativas, preenche uma posição intermédia ou eclética. Outorga poder criador à vontade, ensanchando à entidade por ela criada a faculdade de adquirir personalidade independentemente de qualquer ato administrativo de concessão. Mas exige, por outro, a observância de condições legais predeterminadas, e, desde que a elas atendam, vivem e operam sem constrangimento. (...)".

64 Caio Mário da Silva PereIRA, Instituições de Direito Civil - Introdução ao Direito Civil - Teoria Geral de Direito Civil, vol. I, 22 ${ }^{\mathrm{a}}$ ed. atualizada por Maria Celina Bodin de Moraes, Rio de Janeiro, Forense, 2007, p. 345:

"O direito brasileiro, que pertencia ao primeiro sistema até a vigência da lei de 10 de setembro de 1893 , filia-se atualmente ao das disposições normativas. Não com absoluta rigidez, pois, na verdade, nenhum sistema contemporâneo guarda absoluta fidelidade a um só deles. Por isto mesmo, tem sido classificado como intermédio ou misto. Enquadramo-lo no das disposições normativas porque, salvo casos especiais de exigência de autorização, o princípio dominante é o de que a vontade dos indivíduos, obedecendo a requisitos predeterminados, é dotada do poder de criar a pessoa juridica. Mas, personalidade in fieri, permanece ela em estado potendal até que, preenchidas as exigências alinhadas na lei, converte-se em um status jurídico".

65 Caio Mário da Silva PereIRA, Instituições de Direito Civil - Introdução ao Direito Civil - Teoria Geral de Direito Civil, vol. I, $22^{\mathrm{a}}$ ed. atualizada por Maria Celina Bodin de Moraes, Rio de Janeiro, Forense, 2007, pp. 345 a 347:

"Na criação da pessoa jurídica, há, pois, duas fases: a do ato constitutivo e a da formalidade administrativa do registro.

$\mathrm{Na}$ primeira fase, ocorre a constituição da pessoa jurídica, por ato inter vivos nas associações e sociedades, e por ato inter vivos ou causa mortis nas fundações. É, sempre, uma declaração de vontade, para cuja validade devem ser presentes os requisitos de eficácia dos negócios jurídicos (...).

A segunda fase configura-se no registro. Com o propósito de fixar os principais momentos da vida das pessoas, o direito institui o sistema de registro civil para as pessoas naturais, onde se assentam o seu nascimennento, casamento e morte, onde se averbam as ocorrências acidentais como a interdição, o divórcio, a alteração do nome, etc. Também para as pessoas jurídicas foi criado o sistema de registro, por via do qual ficam anotados e perpetuados os momentos fundamentais de sua existência (começo e fim), bem como as alterações que venham a sofrer no curso de sua vida.

Ontologicamente, porém, há uma diferen;a radical entre o registro das pessoas naturais e o das pessoas jurídicas. $\mathrm{O}$ das primeiras tem uma função exclusivamente probatória, de vez que simplesmente importa em anotar aqueles atos da vida civil ligados ao estado (status), sem qualquer função atributiva, pois não 
Isso importa entre a ausência de registro significa a inexistência da personalidade jurídica, situação que o direito reconhece, disciplinando os entes nesta situação como sociedades comuns $^{66}$, mas distinguindo o seu patrimônio dos dos seus integrantes ou instituidores, uma vez que a separação patrimonial é consequiência da personificação.

Por outro lado, aperfeiçoada a fase da constituição pela declaração de vontade e observada e concluída a fase administrativa do registro, tem-se a aquisição da personalidade jurídica. Cuidou o Código Civil $^{67}$ de fixar o que deve ser declarado no momento da constituição e levado ao conhecimento do registro público, uma vez que este é também fonte de informação dos principais dados da pessoa jurídica que nasce, como a sua denominação, objeto social, duração, local da sede, os seus fundadores ou instituidores e diretores, a sua forma de gestão, presentação e representação, possibilidade de alteração do ato constitutivo, responsabilidade dos membros pelas obrigações sociais e as condições de sua eventual extinção ${ }^{68}$.

decorrem do registro as diversas situações jurídicas dele cosntantes. (...) A personalidade, a capacidade, a restrição que esta sofre advêm de um acontecimento, que o registro patenteia. $\mathrm{O}$ das pessoas jurídicas, ao revés, tem força atributiva, pois que, além de vigorar ad probationem, recebe ainda o valor de providência complementar da aquisição da capacidade jurídica".

66 Caio Mário da Silva PereIRA, Instituições de Direito Civil - Introdução ao Direito Civil - Teoria Geral de Direito Civil, vol. I, $22^{\mathrm{a}}$ ed. atualizada por Maria Celina Bodin de Moraes, Rio de Janeiro, Forense, 2007, p. 347:

"A falta de registro implica, como conseqüência, a ausência de personalidade jurídica. O direito, então, adota uma posição especial, em que defende a aplicação da condição instituída para a personalização e ao mesmo passo encara a situação real criada. A estas entidades deu-lhes o nome de sociedades comuns, para distingui-las das que observam os requisitos de constituição. Enquanto não inscrita no registro próprio, não pode proceder regularmente, regendo-se pelas normas dos arts. 986 e segs. do Código Civil. Assim é que, se vêm a atuar, a lei reconhece-se-lhes a existência e até as regulamenta, embora precariamente e com a finalidade de proteger terceiros que com elas estabeleçam relações, mas lhes nega a personificação (arts. 45 e 985 do Código Civil). A falta de registro tem por efeito a comunhão patrimonial e jurídica da sociedade e de seus membros, como um corolário natural do princípio que faz decorrer do registro a personificação, e desta a separação dos patrimônios".

67 “Art. 46. O registro declarará:

I - a denominação, os fins, a sede, o tempo de duração e o fundo social, quando houver;

II - o nome e a individualização dos fundadores ou instituidores, e dos diretores;

III - o modo por que se administra e representa, ativa e passivamente, judicial e extrajudicialmente;

IV - se o ato constitutivo é reformável no tocante à administração, e de que modo;

$\mathrm{V}$ - se os membros respondem, ou não, subsidiariamente, pelas obrigações sociais;

VI - as condições de extinção da pessoa jurídica e o destino do seu patrimônio, nesse caso".

68 Caio Mário da Silva PereIRA, Instituições de Direito Civil - Introdução ao Direito Civil - Teoria Geral de Direito Civil, vol. I, $22^{\mathrm{a}}$ ed. atualizada por Maria Celina Bodin de Moraes, Rio de Janeiro, Forense, 2007, pp. 347 e 348:

"Da conjugação das duas fases, volitiva e administrativa, e que resulta a aquisição de personalidade. O ato constitutivo é o instrumento continente da declaração da vontade criadora, e a bem dizer, é a causa geradora primária do ente juridico, o qual permanece em estado potencial até o momento em que se realiza a formalidade do registro, $\mathrm{O}$ começo da existência jurídica está fixado no instante em que aquele ato de constituição é inscrito no Registro Público, seja para a para as sociedades ou associações, seja para as fundações. Este registro também a fonte de informação dos dados característicos da entidade, motivo por que mencionará a sua denominação, as suas finalidades e a sua sede. Tendo em vista que as conexões 
Desde o Direito Romano havia discussão se além dos requisitos da constituição por meio de ato de vontade e observância da lei, exigir-se-ia, outrossim, a autorização estatal para a regularidade das pessoas jurídicas. Hoje, tem-se acentado que a exigência é regra excepcional oriunda do direito público ${ }^{69}$, uma vez que nas hipóteses em que o Estado resguarda para si a palavra final para a constituição de pessoas jurídicas, ele o faz por meio de lei, restando a exigência, assim, como corolário do requisito de submissão legal ${ }^{70}$, incidente sobre toda e qualquer pessoa.

Orlando GOMES $^{71}$ fala em dois sistemas para aquisição de personalidade. $\mathrm{O}$ da autorização, pelo qual o reconhecimento da existência legal do ente constituído carece de ato especial do Estado, autorizando o seu funcionamento, e o formalístico, pelo qual a aquisição da personalidade depende tão somente da observância e cumprimento de formalidades legalmente prescritas.

da entidade no mundo jurídico exigem um órgão encarnado em um ou mais indivíduos, referirá ele, ainda, a maneira como se administra e quem tem a função de representação ativa e passiva, em Juízo e fora dele. Esclarecerá a possibilidade e a forma pela qual o ato constitutivo pode ser modificado. A fim de prevenir os que negociarem com a pessoa jurídica, dirá a extensão da responsabilidade de seus membros pelas obrigações sociais. E, finalmente, conterá a previsão das condições de sua extinção e o destino de seu patrimônio (art. 46 do Código Civil IV)".

69 F. C. Pontes De MiRAnda,. Tratado de Direito Privado - Parte Geral - Tomo I - Introdução. Pessoas Físicas e Jurídicas, $4^{\text {a }}$ ed., São Paulo, RT, 1974, p. 359:

"Se a pessoa jurídica só se pode constituir com autorização estatal prévia ou aprovação estatal, o ato de autorização ou de aprovação é de direito público. O ato pode ser para uma só, ou para algumas, porém não, in abstracto, a entidades presentes e futuras que satisfaçam certos requisitos. Só a lei poderia dizêlo, e estaria dispensada a exigência da autorização estatal, que é ato administrativo. (...)".

70 Caio Mário da Silva PereIRA, Instituições de Direito Civil - Introdução ao Direito Civil - Teoria Geral de Direito Civil, vol. I, 22 ${ }^{\mathrm{a}}$ ed. atualizada por Maria Celina Bodin de Moraes, Rio de Janeiro, Forense, 2007, p. 348:

"Como certas atividades estão ligadas a interesses de ordem coletiva, que o Estado precisa submeter a uma vigilância maior, as leis mencionam as entidades para para cujo funcionanento é exigida autorização estatal ou aprovação governamental. Em princípio, pois, vigora no direito brasileiro o critério da liberdade de associação para fins lícitos, tendo a exigência de autorização caráter excepcional, e alcançando apenas alguns tipos de atividades expressamente previstas em lei, como as finalidades securitárias, as atividades flnanceiras, a exploração de energia elétrica ou das riqueza minerais, etc., e, nestes casos, a existência começa com a aprovação (Código Civil, art. 45, in fine)".

71 Introdução ao Direito Civil, $19^{\mathrm{a}}$ ed. atualizada por Edivaldo Brito e Reginalda Paranhos de Brito, Rio de Janeiro, Forense, 2007, p. 175:

"Precisa a pessoa jurídica, para existir, constituir-se por ato jurídico plutilateral, quando revista a forma de associação ou de sociedade, e por ato jurídico unilateral, quando de fundação. (...)

Para adquirirem personalidade, deveria bastar a realização do ato constitutivo, como preconizam os partidários do sistema da livre formação. Começariam a existir logo que constituídas, celebrado o contrato ou realizado o ato coletivo, mas a conveniência de proteger interesses de terceiros, ou sociais, determina a adoção de outros critérios, conforme a finalidade que se tem em vista. Dois sistemas são usados: a) o da autorização; $b$ ) o formalístico. Pelo primeiro, a personalidade adquire-se por ato especial do Estado, com o qual autoriza o funcionamento do grupo constituído. Pelo segundo, a aquisição depende do cumprimento de formalidades previstas na lei, tendentes à sua identificação e publicidade. (...)". 
Importa destacar que carência de autorização estatal, nas hipótses em que é legalmente exigida, importa em obstáculo para a constituição do ente abstrato, diferente da ausência de registro, que importa tão somente na não aquisição da personalidade jurídica pelo ente abstrato, que, no entanto se constitui e sobrevive na condição de Sociedade em Comum $^{72}$.

Pode-se, então concluir, que no Brasil a regra é liberdade na criação das pessoas jurídicas, sendo exceção legal a necessidade de autorização ou aprovação do Poder Público $^{73}$.

Dentre essas exceções legais ${ }^{74}$, interessa enfatizar as instituições financeiras, cujo funcionamento no país deve ser precedido de autorização do Poder Executivo Federal por meio do Banco Central do Brasil, conforme preceitua a Lei do Sistema Financeiro Nacional ou da Reforma Bancária (Lei 4595/64) ${ }^{75}$.

72 Caio Mário da Silva PereIRA, Instituições de Direito Civil - Introdução ao Direito Civil - Teoria Geral de Direito Civil, vol. I, 22 $2^{\mathrm{a}}$ ed. atualizada por Maria Celina Bodin de Moraes, Rio de Janeiro, Forense, 2007, p. 348:

"A falta de autorização, nos casos em que é exigida, impede a constituição da sociedade. Há uma distinção essencial entre ela e a ausência de registro (Código Civil, arts. 986 e segs.), pois que se esta importa em que a sociedade constituída pela manifestação volitiva hábil não chega a adquirir personalidade própria (Código Civil, art. 985), a falta de autorização é obstáculo à constituição mesma da sociedade. A despeito da diferenciação, a lei atenta para a hipótese ele ter-se constituído, sem autorização, e ter atuado uma sociedade para cuja constituição era a autorização necessária (Código Civil, arts. 1.123 e segs.). E o faz para estender-lhe o princípio da responsabilidade (...)".

73 Orlando GoMEs, Introdução ao Direito Civil, $19^{\mathrm{a}}$ ed. atualizada por Edivaldo Brito e Reginalda Paranhos de Brito, Rio de Janeiro, Forense, 2007, p. 175:

"São motivos de ordem pública ou de interesse geral que justificam a intervenção do Estado. Nesses casos, a existência depende de prévia autorização do poder público. O sistema da autorização tem caráter excepcional, coexistindo com o sistema formalístico, ou mesmo, com o da livre-formação".

74 Washington de Barros MonteIro, Curso de Direito Civil - Parte Geral, $41^{\mathrm{a}}$ ed. atualizada por Ana Cristina de Barros Monteiro França Pinto, São Paulo, Saraiva, 2007, p. 151:

"Para que uma entidade desportiva possa funcionar, é necessário tenha obtido licença por meio de alvará, expedido pelo Conselho Nacional de Desportos (Dec.-lei n. 5.342, de 25-3-1943, art. $4^{\circ}$ ).

Os bancos e casas bancárias, nacionais e estrangeiros, só poderão funcionar com autorização do governo. Assim, também as demais instituições financeiras, na forma da Lei n. 4595, de 31-12-1964, art. 18.

Por igual, a inscrição do ato constitutivo de universidades particulares, organizadas sob a forma de associações ou fundações, será precedida de autorização de funcionamento e credenciamento de cursos pelo poder público, por prazo limitado, que poderá ser renovado periodicamente, após processo regular de avaliação (Lei 9.394, de 20-12-1996, art. $7^{\circ}$, c/c o art. 46).

Idêntica autorização se exige ainda das companhias de mineração ou exploração de jazidas, das sociedades de economia coletiva, navegação de cabotagem, aproveitamento de quedas d'água, energia elétrica, construção e exploração de ponte etc".

75 Lei 4595/64:

"Art. 10 - Compete privativamente ao Banco Central da República do Brasil:

(...)

$\mathrm{X}$ - Conceder autorização às instituições financeiras, a fim de que possam:

a) funcionar no País;

b) instalar ou transferir suas sedes, ou dependências, inclusive no exterior;

c) ser transformadas, fundidas, incorporadas ou encampadas; 
Merecem, também, destaque os Partidos Políticos, para os quais o ordenamento jurídico exige dois registro, vez que além do competente Registro Civil, devem submeter seus atos constitutivos ao Tribunal Superior Eleitoral, por força de sua Lei Orgânica e de Resolução do próprio $\operatorname{TSE}^{76}$.

Outra disciplina recebem as Sociedades de Advogados, que por força legal Estatuto da Advocacia da $\mathrm{OAB}^{77}$ - e regulamentar - Provimento do Conselho Federal da Ordem dos Advogados do Brasil - têm de registrar seus atos constitutivos na própria OAB e estão proibidas de fazê-lo no Registro Civil ou no Mercantil.

A propósito, merece crítica e reforma a legislação partidária, que mais apropriadamente deveria seguir o exemplo do Estatuto da Advocacia e conceder a personalidade jurídica às agremiações partidárias quando do julgamento de procedência do seu pedido de registro, dispensando-as de, antes, socorrer-se do Registro Civil, o qual acaba sendo sendo anódino, visto que a última palavra será dada pelo Tribunal Superior Eleitoral, aliás, Corte de Justiça competente para aferir se os requerentes lograram êxito no cumprimento das exigências legais e regulamentares para que nasça um novo Partido Político no país.

\subsection{A Personalidade e a Capacidade da Pessoa Jurídica}

Em Roma, as corporações, figuras com personalidade jurídica inicialmente reconhecida pelo seu direito privado, exerciam seus direitos e cumpriam seus deveres por meio de representantes, que podiam ser permanentes, designados de magister ou curator, ou especiais, designados de actor ou defensor. Já no direito romano, portanto, gozava a pessoa jurídica de plena capacidade, não sendo este atributo mitigado em razão da necessidade de exercício de direitos e obrigações por meio de pessoas naturais. Tal fato, em verdade, decorre da natureza abstrata destes entes e consigna que seus presentantes ao

d) praticar operações de câmbio, crédito real e venda habitual de títulos da dívida pública federal, estadual ou municipal, ações, debêntures, letras hipotecárias e outros títulos de crédito ou mobiliários;

e) ter prorrogados os prazos concedidos para funcionamento;

f) alterar seus estatutos;

g) alienar ou, por qualquer outra forma, transferir o seu controle acionário.

(...)".

76 Lei 9096/95 - Lei Orgânica dos Partidos Políticos.

A norma do Tribunal Superior Eleitoral que regulamenta os dispositivos da Lei Orgância dos Partidos Políticos é a Resolução TSE n. 19.406, de 05 de dezembro de 1995.

77 Lei 8906/94 - Estatuto da Advocacia e da OAB.

A regulamentação destes dispositivos se dá por meio dos Provimentos 69/89 e 112/2006, ambos do Conselho Federal da Ordem dos Advogados do Brasil. 
agirem não expressam sua própria vontade de pessoa natural, mas a vontade da pessoa jurídica, muitas vezes, até mesmo, não coincidentes ou até colidentes ${ }^{78}$.

Novamente aflora a resistência da concepção romanística em admitir a personalidade das pessoas jurídicas, visto que não lhe reputavam capazes de obrar de per si e de consentir ou expressar sua vontade. E também oportuna é a lição de PONTES DE MIRANDA $^{79}$, que, com estribo na concepção germânica, chamou de presentação o exercício da capacidade das pessoas jurídicas por meio de seus órgãos, contrapondo à idéia de representação, justamente, a de órgão. Nessa medida, os seus administradores, ungidos na exata forma prescrita na lei ou em seu ato constitutivo, são em verdade órgãos da pessoa jurídica e ao agirem manifestam a vontade do ente personificado, não o representando, mas sendo ele próprio:

"Os órgãos exprimem vontade, ou exprimem conhecimento, ou sentimento; os órgãos que exprimem vontade são os que dirigem, ou resolvem, internamente, ou praticam atos jurídicos stricto sensu e negócios jurídicos; os atos-fatos jurídicos podem ser praticados por outros, conforme os estatutos.

Quanto à natureza do órgão, é de afastar-se (a) que seja representante, e a teoria que o sustentou invocava o direito romano que nunca disso cogitou, nem tinha a nossa concepção de representação. (b) Órgão é órgão, não é representante voluntário, nem legal: a personalidade do membro do órgão, ou do membro único, não aparece, não se leva em conta, o que não ocorreria se de representação se tratasse; o órgão atua e recebe, como o braço, a mão, a bôca, ou os ouvidos humanos; o ato e a receptividade são da pessoa jurídica (F. REGELSBERGER, Pandekten, I, 323), porque resulta

78 J. C. MoreIRA Alves, Direito Romano, vol. 1, $13^{\text {a }}$ ed., Rio de Janeiro, Forense, 2003, p. 135:

"A corporação exerce seus direitos por meio de representante: magister ou curator eram as designações de seus representantes permanentes; actor ou defensor, as denominações de seus representantes especiais (assim, quando uma associação ingressa em juízo para a defesa de seus direitos subjetivos, o representante especial para esse fim é o actor ou defensor), os quais, no direito pós-clássico, passaram a ser indicados pelo vocábulo bizantino syndicus. Note-se que a necessidade de a pessoa jurídica servir-se de representante (pessoa física) para exercer seus direitos não quer dizer que ela não tem capacidade de fato. Toda pessoa jurídica é capaz de fato, pois à sua vontade (que é a vontade da maioria dos associados revelada nas assembléias) não podem aplicar-se os fatores que retiram ou diminuem a capacidade de fato das pessoas físicas (a idade, o sexo, a alienação mental e a prodigalidade)".

79 Tratado de Direito Privado - Parte Geral - Tomo I - Introdução. Pessoas Físicas e Jurídicas, $4^{\mathrm{a}}$ ed., São Paulo, RT, 1974,, pp. 286 e 287. 
da sua organização constitucional, do seu ato constitutivo ou dos estatutos, no que órgão se distingue de empregado (E. RHOMBERG, Körperschaftliches Verschulden, 22). O preposto, o empregado e o estranho podem representar a pessoa jurídica, não podem funcionar como órgão, sem o ser. O porteiro é empregado, não é órgão. $\mathrm{O}$ caixa-recebedor e o caixa-pagador são empregados; se praticam atos jurídicos stricto sensu e negócios jurídicos, são, também, representantes, não órgãos; para que fôssem órgãos, teriam de o dizer os estatutos ou o ato constitutivo. Não há pessoa jurídica sem órgão, inclusive sem órgão para a vida externa. Exatamente porque o órgão não representa, a pessoa jurídica é capaz de obrar”.

Isso posto, não se pairam mais dúvidas acerca da personalidade dos entes abstratos, na medida que ser pessoa é ter capacidade jurídica ${ }^{80}$, ou seja, ser sujeito de direitos e obrigações na ordem civil ${ }^{81},{ }^{82}$, ressaltando-se que essa capacidade das pessoas jurídica em

80 A. DE CUPIS, (s/ título original), trad. port. de Adriano Vera Jardim e Antonio Miguel Caeiro, Os Direitos da Personalidade, , Lisboa, Morais, 1961, pp. 13 e 14:

"A personalidade, ou capacidade jurídica, é geralmente definida como sendo uma susceptibilidade de ser titular de direitos e obrigações jurídicas. Não se identifica nem com os direitos nem com as obrigações, e nem é mais do que a essência de uma simples qualidade jurídica.

Uma tal qualidade jurídica é um produto do direito positivo, e não uma realidade que este encontre já constituída na natureza e que se limite a registar tal como a encontra. A susceptibilidade de ser titular de direitos e obrigações não está, no entanto, menos vinculada ao ordenamento positivo do que estão os direitos e obrigações. (...)

O ordenamento jurídico é, pois, árbitro na atribuição da personalidade. A confirmação histórica foi-nos dada quando o princípio de que a personalidade diz respeito a todos igualmente, salvo as limitações estabelecidas na lei, sofreu uma ulterior limitação (sucessivamente eliminada) devida às preocupações de índole racial. Tal característica manifesta-se igualmente na atribuição da personalidade aos nascituros e a entes diversos dos homens .

$\mathrm{O}$ arbítrio do ordenamento jurídico respeitante à atribuição da personalidade é, por outro lado, limitado pela necessidade de um lelemento natural, e pela impossibilidade, para o mesmo ordenamento, de funcionar prescindindo totalmente da atribuição da personalidade. Dentro destes limites, o referido arbítrio exerce-se soberanamente e, uma vez que o ordenamento jurídico munido desse arbitrio tenha regulado de uma determinada forma a atribuição da personalidade, não podem os seus destinatários alterar essa forma. (...)".

81 F. C. Pontes De MiRANDA,. Tratado de Direito Privado - Parte Geral - Tomo I - Introdução. Pessoas Físicas e Jurídicas, $4^{\text {a }}$ ed., São Paulo, RT, 1974, p. 288:

"Ser pessoa é ser capaz de direitos e deveres. Ser pessoa jurídica é ser capaz de direitos e deveres, separadamente; isto é, distinguidos o seu patrimônio e os patrimônios dos que a compõem, ou dirigem. Se há direito da entidade, antes de ser pessoa jurídica, à personificação, depende do direito positivo, em tôda a sua escala (direito das gentes, direito constitucional estatal, direito administrativo, direito privado). (...)".

82 Caio Mário da Silva PereIRA, Instituições de Direito Civil - Introdução ao Direito Civil - Teoria Geral do Direito Civil, vol. I, $22^{\mathrm{a}}$ ed. atualizada por Maria Celina Bodin de Moraes, Rio de Janeiro, Forense, 2007, pp. 310 e 311 :

"A capacidade das pessoas jurídicas é uma consequiência natural e lógica da personalidade que lhes reconhece o ordenamento legal. Se têm aptidão genérica para adquirir direitos e contrair obrigações, 
nenhum momento se confunde com a de seus membros ou com a daqueles que preenchem os seus órgãos ${ }^{83}$.

Os órgãos da pessoa jurídica podem ser necessários ou facultativos, conforme sejam exigidos pela lei, como por exemplo a Diretoria das Sociedades Anônimas ${ }^{84}$, ou simplesmente designados como tal pelo ato constitutivo, porém ostentando essa condição presentam a pessoa jurídica e não se há de falar em representação ${ }^{85}$. Em ambos os casos,

obviamente se lhes deve atribuir o poder necessário, e, mais ainda, a aptidão específica para exercê-los. (...)".

83 F. C. Pontes de Miranda,. Tratado de Direito Privado - Parte Geral - Tomo I - Introdução. Pessoas Físicas e Jurídicas, $4^{\mathrm{a}}$ ed., São Paulo, RT, 1974, p. 289:

“As pessoas jurídicas', diz o art. 20, 'têm existência distinta da dos seus membros'. Não se trata, a rigor, de regra jurídica. Apenas, tautòlogicamente se enuncia que as pessoas jurídicas têm capacidade de direito, que as pessoas jurídicas são pessoas. Além disso, as pessoas jurídicas, ainda que tratem com os seus membros, se a lei e o ato constitutivo não lhes veda tais negócios jurídicos, ficam como pessoas diante das pessoas dos seus membros. Aquêle que lhe compra, ou vende alguma coisa, ainda que assine por ela, como seu representante ou órgão, não faz contrato consigo mesmo. (...)".

84 Lei 6.404/76:

“Art. 143. A Diretoria será composta por 2 (dois) ou mais diretores, eleitos e destituíveis a qualquer tempo pelo conselho de administração, ou, se inexistente, pela assembléia-geral, devendo o estatuto estabelecer:

I - o número de diretores, ou o máximo e o mínimo permitidos;

II - o modo de sua substituição;

III - o prazo de gestão, que não será superior a 3 (três) anos, permitida a reeleição;

IV - as atribuições e poderes de cada diretor.

(...)

$\S 2^{\circ} \mathrm{O}$ estatuto pode estabelecer que determinadas decisões, de competência dos diretores, sejam tomadas em reunião da diretoria.

Art. 144. No silêncio do estatuto e inexistindo deliberação do conselho de administração (artigo 142, n. II e parágrafo único), competirão a qualquer diretor a representação da companhia e a prática dos atos necessários ao seu funcionamento regular.

Parágrafo único. Nos limites de suas atribuições e poderes, é lícito aos diretores constituir mandatários da companhia, devendo ser especificados no instrumento os atos ou operações que poderão praticar e a duração do mandato, que, no caso de mandatojudicial, poderá ser por prazo indeterminado".

Modesto Carvalhosa, Comentários à Lei de Sociedades Anônimas, $3^{\circ}$ vol., $4^{\mathrm{a}}$ ed., São Paulo, Saraiva, 2009, pp. 160 e 163:

"A diretoria é um órgão necessário da administração de todas as companhias, (...). Não é um órgão colegiado permanente ( $\$ 2^{\circ}$ deste art. 143$)$, pois seus membros têm poderes de representação e exercem funções individualmente sem embargo da deliberação colegiada $\left(\$ 2^{\circ}\right)$. Exatamente aí reside a diferença entre Conselho de Administração e diretoria. Esta é um órgão que reúne um conjunto de poderes e atribuições harmônicas entre os seus membros, os quais os exercem individualmente. Já o Conselho de Administração é um órgão que reúne um conjunto de poderes e atribuições, que são exercitados coletivamente pelos seus membros.

(...)

Os diretores, tanto quanto o Conselho de Administração, têm poderes decisórios que lhes são atribuídos por lei e pelo estatuto.

A única distinção - insistindo - entre a diretoria e o Conselho é quanto à forma de decisão. Na diretoria, ela é individual, em regra; ao passo que, no Conselho, ela é sempre deliberativa ou colegial permanente $\left(\$ 2^{\circ}\right)$. Mesmo quando a decisão da diretoria sobre determinadas matérias for tomada em reunião, não logra o órgão revestir-se de caráter colegial. Apesar de a decisão ser coletiva, o poder de executá-la é individual daquele diretor que o estatuto, para tanto, designou.

Os diretores têm, portanto, em qualquer hipótese, as funções de gestão e de representação da sociedade, conforme o que, a respeito, dispuser, para cada um deles, o estatuto social".

85 F. C. Pontes De MiRAndA,. Tratado de Direito Privado - Parte Geral - Tomo I - Introdução. Pessoas Físicas e Jurídicas, $4^{\text {a }}$ ed., São Paulo, RT, 1974, pp. 289 e 290: 
somente o ato constitutivo ou o estatuto podem criá-los, dizer quem nomeia ou elege a pessoa ou colegiado que preencherá o órgão ou fixar-lhe os poderes de presentação $^{86}$.

O importante frisar é que a competência e a fonte de provimento do órgão deriva do ato constitutivo ou do estatuto e assim não sendo não se há de falar em órgão ou em presentação, mas em empregado ou representante, como é o caso daquele que recebe poderes ou funções de um órgão da pessoa jurídica, mas não diretamente do ato constitutivo ou do estatuto ${ }^{87}$.

Depreende-se, nesse ponto, a ênfase com que PONTES DE MIRANDA ${ }^{88}$ afirma que os atos praticados por aquele que não é órgão na exata forma do ato constitutivo ou do

“Os órgãos ou são necessários ou são facultativos. A diretoria e a assembléia geral, nas sociedades e associações são órgãos necessários; os mais, facultativos. O órgão facultativo é a pessoa física, ou colégio, grupo de pessoas físicas, que o ato constitutivo ou os estatutos soldaram à pessoa jurídica, tornando-o parte do organismo social. Mediante essa soldagem, o que seria empregado ou representante passa a ser órgão: o que êle faz não é como preposto, locador de serviços, ou, em geral, trabalhador; mas como órgão: os atos dêle são da pessoa jurídica, como órgão, e não como representante (= em nome da pessoa jurídica); nem como núncio de quem é órgão da pessoa jurídica. Daí não se dever pensar em outorga de poderes de representação ao órgão; nem, sequer, em poderes de representação, por fôrça de lei, como se dá com o titular do pátrio poder, tutor e o curador (sem razão E. BILlMANN, Haftung der juristischen Personen, 11). (...)".

86 F. C. Pontes De Miranda,. Tratado de Direito Privado - Parte Geral - Tomo I - Introdução. Pessoas Físicas e Jurídicas, $4^{\mathrm{a}}$ ed., São Paulo, RT, 1974, p. 290:

“Os órgãos, necessários ou facultativos, só os criam atos constitutivos e estatutos, só os atos constitutivos e os estatutos dizem como se nomeia ou elege a pessoa ou colégio, só os atos constitutivos e os estatuos dizem quais são os poderes (poderes, dissemos; e não poder de representação). Se a pessoa ou pessoas que compõem o órgão atuam fora dos limites da competência, o ato não é ato de órgão. portanto, não é ato da pessoa jurídica. (...)".

87 F. C. Pontes De Miranda,. Tratado de Direito Privado - Parte Geral - Tomo I - Introdução. Pessoas Físicas e Jurídicas, $4^{\text {a }}$ ed., São Paulo, RT, 1974, pp. 290 e 291:

“(...) É preciso, outrossim, que os atos constitutivos e os estatutos digam quais as funções e quem as provê. O provimento pode ser pela diretoria, ou por outro órgão, ou por terceiro (e.g. o Estado). Basta que se determine quem provê; não se precisa determinar como se provê. Determinando quem provê, tal função é indelegável (H. G. STIFF, Der Begriff des verfassungsmässigen Vertreters, 20). (...) A fonte de provimento há de estar no ato constitutivo ou nos estatutos; se não se dá isso, não há pensar-se em órgão, mas em representante, ou empregado. Quanto à determinação das funções, também o que recebe funções do órgão, e não do ato constitutivo ou dos estatutos, não é órgão (sem razão, E. SCHLEGELMILCH, Die Haftung der juristischen Personen, 51; H. G. STIFF, Der Begriff des verfassungsmässigen Vertreters, 23.

88 Tratado de Direito Privado - Parte Geral - Tomo I - Introdução. Pessoas Físicas e Jurídicas, $4^{\mathrm{a}}$ ed., São Paulo, RT, 1974, pp. 291 e 292:

"Seja como fôr, não há função de órgão se o ato constitutivo ou os estatutos não a conhecem (...) Por outro lado, a pessoa jurídica não é responsável pelo ato do órgão que não obedeceu a forma que o ato constitutivo ou os estatutos exigiram (A. LEVY, Begriff und Rechtsnatur, 37 s.; H. G. STIFF, Der Begriff des vergassungsmässigen Vetreters, 26), sem que se possa distinguir entre as violações das regras de forma, como fazia G. KRÜGER (Die Haftung der juristischen Personen, 34). O órgão pode ser subordinado, ou não, no todo, ou em parte, a outro órgão.

Se o provimento ou o ato do órgão infringiu o ato constitutivo ou os estatutos, a aprovação pelo órgão competente sana a invalidade, salvo se o ato constitutivo ou os estatutos fazem subsistente a invalidade, o que, na dúvida, não se há de entender. Não se pode afirmar, a priori, como O. VON GIERKE (Die Genossenschaftstheorie, 676 e 686), a sanação. Se não houve sanação, o ato não foi ato da pessoa jurídica (G. KRÜGER, Die Haftung de juristischen Personen, 23; F. KLING-MÜLLER, Die Haftung für Vereinsorgane, 46)". 
estatuto ou que tenha agido fora dos limites de sua competência ou diferente da forma prescrita, não são atos da pessoa jurídica, podendo o órgão competente até vir posteriormente a saná-los, mas somente não assim vedando o mesmo ato constitutivo ou o estatuto.

E da mesma forma que se criam e se preenchem os órgãos da pessoa jurídica, também se os extinguem e se destitui ou demite as pessoas que os compõem. A criação deriva do ato constitutivo ou do estatuto e a extinção, da mesma maneira, somente é possível por meio de modificação desses documentos ou da inserção neles de ato constitutivo negativo. Já a destituição da pessoa ou pessoas que preenchem os órgãos se dá por meio de ato do órgão que elegeu ou nomeou ou por transcurso do interregno para o qual foram as pessoas designadas para preencher o órgão ${ }^{89}$.

Também lançando mão da designação de órgãos para qualificar o aparelhamento técnico de que necessita a pessoa jurídica para exercer os direitos de que é titular em razão de sua personalidade, Caio Mário da Silva PEREIRA ${ }^{90}$ explica que os entes abstratos não detem a vontade natural imanente às pessoas física, mas o direito ao lhes reconhecer a

89 F. C. Pontes De MiRAndA,. Tratado de Direito Privado - Parte Geral - Tomo I - Introdução. Pessoas Físicas e Jurídicas, $4^{\mathrm{a}}$ ed., São Paulo, RT, 1974, p. 287 :

"O órgão deixa de ser órgão, portanto de poder praticar atos da pessoa jurídica, desde que se extinga como órgão; não desde que se lhe tire a prática de algum, ou alguns atos da pessoa jurídica. A extinção há de ser por modificação do ato constitutivo ou dos estatutos, isto é, ato cionstitutivo negativo que naquele, ou nêsses, se insira. Falar-se, aí, de revogação é impróprio; não se revoga o ato constitutivo, nem se revogam os estatutos, desconstitui-se aquêle, ou se desconstituem esses, com eficácia ex nunc; o ataque é ao ato mesmo, qual existe, em contrarius actus, e não em revogação (êrro que cometeram alguns juristas, entre êles H. G. STIFF, Der Begriff des verfassungsmässigen Vertreters, 33). A destituição ou demissão atinge a pessoa que enche o órgão, ou as pessoas que enchem o órgão (= que o compõem), não o órgão mesmo. O órgão surge quando se cria o órgão, a pessoa ou pessoas que o compõem surgem quando se nomeiam, ou elegem. O órgão desaparece quando por modificação do ato constitutivo ou dos estatutos se extingue; a pessoa ou pessoas, que o compunham, deixam de enchê-lo qunado são destituídas, ou acaba o tempo para o qual foram insertas no órgão. (...)”.

90 Instituições de Direito Civil - Introdução ao Direito Civil - Teoria Geral do Direito Civil, vol. I, $22^{\mathrm{a}}$ ed. atualizada por Maria Celina Bodin de Moraes, Rio de Janeiro, Forense, 2007, pp. 312 e 313:

"Sob o aspecto do exercício dos direitos, é de notar-se a disparidade prática entre a pessoa natural e a pessoa jurídia. É que não sendo esta dotada de uma individualidade fisiopsíquica, tem sempre de se servir de órgãos de comunicação para os contatos jurídicos, seja com outras entidades da mesma natureza, seja com as pessoas naturais. Esta drcunstância chegou mesmo a inspirar juristas de grande porte na sustentação de sua incapacidade, que defendiam dizendo que, se os entes morais não podem exercer diretamente os direitos, é porque lhes falta o atributo da capacidade. Modetnamente não se coloca mais a questão nestes termos. Reconhecem os doutrinadores e o direitos positivo a capacidade das pessoas jurídicas, mas assinala-se que possuem aptidão para adquirir direitos, e, no momento de exercê-los, necessitam de aparelhamento técnico. Não é a ausência de vontade própria o bastante para se recusar capacidade à pessoa jurídica, pois que também a criança e o louco não têm vontade e são dotados de capacidade de direito ou de gozo. Exatamente porque as pessoas morais não dispõem de manifestação direta de vontade é que a lei, reconhecendo-lhes os atributos da personalidade, condiciona o exercício dos direitos aos seus órgãos de deliberação e representação. Na verdade, se a pessoa jurídica não tem uma vontade natural, é certo também que nela a vontade humana opera condicionada ao fim da organização". 
capacidade civil condiciona a expressão de sua vontade por meio de órgãos de deliberação e representação. E, embora sem a precisão técnica de distinguir os termos representação e presentação, conclui que o contato da pessoa jurídica com o mundo exterior é estabelecido por esses órgãos, os quais sob esse aspecto, tem existência dupla, ora como sendo as pessoas físicas que os preenchem, ora como sendo a própria pessoa jurídica, mas não se confundindo ${ }^{91}$.

O Código Civil $^{92}$ brasileiro assegura à pessoa jurídica o gozo dos direitos da personalidade $^{93}$ que lhe possam ser compatíveis ${ }^{94},{ }^{95}$. Confundem-se, assim, na acepção técnica, a personalidade e a capacidade jurídica, visto que ser pessoa é ser capaz, ou seja, é ser titular de direitos e obrigações, sem se descurar que sendo a personalidade e esses direitos e obrigações, ambos decorrência do ordenamento jurídico, não se confundem. É a

91 Caio Mário da Silva PereIRA, Instituições de Direito Civil - Introdução ao Direito Civil - Teoria Geral do Direito Civil, vol. I, 22 a ed. atualizada por Maria Celina Bodin de Moraes, Rio de Janeiro, Forense, 2007, p. 313:

"É por isso que se diz ser a pessoa jurídica representada ativa e passivamente nos atos judiciais como nos extrajudiciais. Seus contatos com o mundo real exigem a presença de órgãos que os estabeleçam. Seu querer, que é resultante das vontades individuais de seus membros, exige a presença de um representante para que seja manifestado externamente. E, como estes órgãos são pessoas naturais, têm uma existência jurídica sob certo aspecto dupla, pois que agem como indivíduos e como órgãos da entidade de razão". "Art. 52 - Aplica-se às pessoas jurídicas, no que couber, a proteção dos direitos da personalidade".

93 Carlos Mário da Silva Velloso, Os Direitos da Personalidade no Código civil Português e no novo Código Civil Brasileiro, in Aspectos Controvertidos do Novo Código Civil - Escritos em Homenagem ao Ministro José Carlos Moreira Alves, São Paulo, RT, 2003, p. 117:

"Na esfera privada temos, então, os direitos da personalidade, terminologia que, registra César Fiúza, foi cunhada por Otto Gierke, e, na esfera pública, direitos humanos, direitos fundamentais, liberdades públicas.

O Código Civil italiano, de 1942, foi precursor na ordenação e sistematização da matéria. Regulou ele, no Livro I, Título I, os difeitos da personalidade, nos arts. $5 .^{\circ}$ a 10 . Noart. $5 .^{\circ}$, disciplinou o ato de disposição do próprio corpo; nos arts. $6 .^{\circ}$ a $8 .^{\circ}$, o direito ao nome; no art. $9 .^{\circ}$ o pseudônimo e, no art. 10 , o direito à imagem".

94 Carlos Alberto BITTAR, Os Direitos da Personalidade, $3^{\mathrm{a}}$ ed. atualizada por Eduardo Carlos Bianca Bittar, Rio de Janeiro, Forense Universitária, 1999, pp. 13 e 14:

"Por fim, são eles plenamente compatíveis com pessoas jurídicas, pois, como entes dotados de personalidade pelo ordenamento positivo (Código Civil, arts. 13, 18 e 20), fazem jus ao reconhecimento de atributos intrínsecos à sua essencialidade, como, por exemplo, os direitos ao nome, à marca, a símbolos e à honra. Nascem com o registro da pessoa jurídica, subsistem enquanto estiverem em atuação e terminam com a baixa do registro, respeitada a prevalência de certos efeitos posteriores, a exemplo do que ocorre com as pessoas físicas (como, por exemplo, com o direito moral sobre criações coletivas e o direito à honra)".

95 Caio Mário da Silva PereIRA, Instituições de Direito Civil - Introdução ao Direito Civil - Teoria Geral do Direito Civil, vol. I, 22 a ed. atualizada por Maria Celina Bodin de Moraes, Rio de Janeiro, Forense, 2007, p. 340:

"Os direitos da personalidade são atributos da pessoa física. A ela concede-se a proteção de sua integridade física e moral. Tendo em vista que a pessoa jurídica é uma criação do direito para a realização das finalidades humanas, o Código, no art. 52, estende-lhe as garantias que a ela são asseguradas, evidentemente naquilo em que houver cabimento". 
personalidade pré-condição desses direitos e obrigações, visto que estes não podem subsitir sem as passoas que lhe sejam titulares ${ }^{96}$.

A capacidade jurídica das pessoas físicas é, por regra, plena e ilimitada ${ }^{97}$, sendo somente excepcionada nas hipóteses previstas pelo próprio Estatuto Civil ${ }^{98}$. Já para a pessoa jurídica, porém, sua personalidade ou capacidade, são mitigadas em relação à da pessoa física, em razão, óbvio, de sua própria natureza abstrata ${ }^{99},{ }^{100},{ }^{101}$.

96 A. DE CuPIS, (s/ título original), trad. port. de Adriano Vera Jardim e Antonio Miguel Caeiro, Os Direitos da Personalidade, , Lisboa, Morais, 1961, p. 15:

“A personalidade, se não se identifica com os direitos e com as obrigações jurídicas, constitui a précondição deles, ou seja, o seu fundamento e pressuposto.

Óbvio é que, enquanto simples susceptibilidade de ser titular de direitos e obrigações, deve ser algo diferente destes; mas para ser «susceptibilidade» é ao mesmo tempo fundamento sem o qual os mesmos direitos e obrigações não podem subsistir. Não se pode ser sujeito de direitos e obrigações se não se está revestido dessa susceptibilidade, ou da qualidade de «pessoa».

No que diz respeito particularmente aos direitos, tem-se recorrido à imagem da ossatura, que aliás se pode aplicar igualmente às obrigações: a personalidade seria uma ossatura destinada a ser revestida de direitos, assim como os direitos seriam destinados a revestir ossatura".

97 Código Civil:

“Art. $1^{\circ}$ - Toda pessoa é capaz de direitos e deveres na ordem civil".

98 Código Civil:

"Art. $3^{\circ}$ - São absolutamente incapazes de exercer pessoalmente os atos da vida civil: I - os menores de dezesseis anos; II - os que, por enfermidade ou deficiência mental, não tiverem o necessário discernimento para a prática desses atos; III - os que, mesmo por causa transitória, não puderem exprimir sua vontade.

Art. $4^{\circ}$ - São incapazes, relativamente a certos atos, ou à maneira de os exercer: I - os maiores de dezesseis e menores de dezoito anos; II - os ébrios habituais, os viciados em tóxicos, e os que, por deficiência mental, tenham o discernimento reduzido; III - os excepcionais, sem desenvolvimento mental completo; IV - os pródigos.

Parágrafo único - A capacidade dos índios será regulada por legislação especial”.

99 F. C. PONTES De MiRAndA,. Tratado de Direito Privado - Parte Geral - Tomo I - Introdução. Pessoas Físicas e Jurídicas, $4^{\mathrm{a}}$ ed., São Paulo, RT, 1974, p. 288:

“(...) No direito brasileiro, a pessoa jurídica é capaz de todos os direitos, salvo, está visto, aquêles que resultam de fatos jurídicos em cujo suporte fáctico há elemento que ela não pode satisfazer (e.g., ser parente, para suceder legitimamente, ou ter pretensão a alimentos). O direito público por vêzes lhe atribui direitos subjetivos, pretensões, ações e exceções, como acontece aos partidos políticos e aos sindicatos.

As pessoas jurídicas podem, em princípio, ser titular de qaisquer direitos patrimoniais, incluída a posse, direitos autorais, direitos de marca de indústria e de comércio, direitos formativos geradores, modificativos e extintivos, direito ao nome. (...). O destino do patrimônio, após a extinção, parece-se com a sucessão testamentária, porém de modo nenhum se identifica com ela. Têm alguns direitos de personalidade, conforme exporemos, inclusive quanto à honra, cabendo-lhes a ação de indenização. Têm deveres, obrigações, legitimação passiva nas ações e exceções e legitimação processual passiva. As demandas são entre elas e as outras partes. A sentença tem eficácia contra elas e a favor delas, como a respeito de pessoas físicas, salvo no que concerne a prisão e outras medidas que se limitam às pessoas físicas.

Se exercem empêsa comercial, são comerciantes, como as pessoas físicas".

100 Washington de BARros MonteIro, Curso de Direito Civil - Parte Geral, 41 a ed. atualizada por Ana Cristina de Barros Monteiro França Pinto, São Paulo, Saraiva, 2007, p. 133:

"Em regra, a pessoa jurídica tem os mesmos direitos que a pessoa natural: pode contratar, adquirir por testamento, sujeita-se à prescrição (Cód. Civil de 2002, art. 195). Exerce ainda alguns direitos personalíssimos, como a nacionalidade e o nome.

Mas, obviamente, não pode casar, adotar ou testar, nem exercer a testamentaria, nem ser acionista de empresa jornalística. Como expressava o Anteprojeto ORLANDO GOMES (art. 65), as pessoas jurídicas 
Sílvio de Salvo VenosA ${ }^{102}$ alerta, ainda acerca da limitação da capacidade da pessoa jurídica, uma vez que esta, por regra, deve se quedar circunscrita à sua finalidade ou objeto social, o que embora não seja uma regra absoluta e estanque, não deixa também de ser uma mitigação da plena capacidade jurídica. Na mesma linha, Caio Mário da Silva PEREIRA $^{103}$ menciona o princípo da especialização, pelo qual a pessoa jurídica tem sua capacidade limitada aos fins que persegue, o que não deve ser levado ao extremo restritivo, mas obtemperado no sentido de que a pessoa jurídica goze de direitos e deveres suficientes à plena execução dos seus objetivos.

No mesmo sentido é a lição de PONTES DE MiRAndA, para quem os poderes de presentação dos órgãos da pessoa jurídica são limitados aos fins sociais, não se devendo apurar, caso a caso, se há fim individual da pessoa jurídica, mas bastando que o ato caiba no fim expresso no registro ${ }^{104}$.

podem adquirir os direitos e assumir as obrigações que, por sua natureza, não sejam privativos da pessoa humana".

101 Caio Mário da Silva PereIRA, Instituições de Direito Civil - Introdução ao Direito Civil - Teoria Geral do Direito Civil, vol. I, 22 a ed. atualizada por Maria Celina Bodin de Moraes, Rio de Janeiro, Forense, 2007, p. 311:

“(...) No se lhes evidenciar a capacidade, costuma-se adotar por símile a das pessoas naturais, porém não é exata a aproximação em todos os seus termos. Enquanto a pessoa física encontra na sua capacidade a expansão plena de sua alteridade ou de seu poder de ação, com linhas de generalidades que lhe asseguram extensão ilimitada (em tese), as pessoas jurídicas, pela própria natureza, têm o poder jurídico limitado aos direitos de ordem patrimonial. Falta-lhes, portanto, a tiularidade daqueles que a transcendem, como os de família ou de sucessão legítima, e outros que são inerentes à pessoa humana ou pressupõem a individualidade humana".

102 Direito Civil - Parte Geral, vol. 1, $3^{\text {a }}$ ed., São Paulo, Atlas, 2003, pp. 260 e 261:

"Decorre daí que, enquanto a capacidade da pessoa natural pode ser ilimitada e irrestrita, a capacidade da pessoa jurídica é sempre limitada a sua própria órbita. Essa limitação não pode ser tal que nulifique as finalidades para as quais a pessoa foi criada, nem ser encarada de forma a fixar-se a atividade da pessoa jurídica apenas para a sua finalidade. Vezes há em que a pessoa jurídica, ao agir, extravasa seus ordenamentos internos, sem que com isso seus atos possam ser tidos como ineficazes. Para considerá-los como tal, é necessário o exame de cada caso concreto, sem se olvidar que a pessoa jurídica também possui uma capacidade genérica".

103 Instituições de Direito Civil - Introdução ao Direito Civil - Teoria Geral do Direito Civil, vol. I, $22^{\mathrm{a}}$ ed. atualizada por Maria Celina Bodin de Moraes, Rio de Janeiro, Forense, 2007, p. 311:

"Confrontando, ainda, a capacidade da pessoa jurídica com a da pessoa natural, os autores mostram que a desta é ilimitada, enquanto que a daquela é restrita, em razão de sua personalidade ser reconhecida na medida dos fins perseguidos. E, sendo assim, a pessoa jurídica deve ter sua capacidade limitada à órbita de sua atividade própria, ficando-lhe interdito atuar fora do campo de seus fins específicos. É a isto que se chama de princípio da especialização, imposto em virtude da própria natureza da personalidade moral. Não se pode, contudo, levar a doutrina da especialização às últimas conseqüências, nem se concebe que uma pessoa jurídica tenha a sua capacidade delimitadaespecíficamente aos fins que procura realizar. Podemos, então, aceitar o princípio com aquela mitigação que lhe trazem Rossel e Mentha, isto é, que a pessoa juridica tem o gozo dos direitos civis que lhe são necessários à realização dos flns justificativos de sua existência".

104 Tratado de Direito Privado - Parte Geral - Tomo I - Introdução. Pessoas Físicas e Jurídicas, $4^{\mathrm{a}}$ ed., São Paulo, RT, 1974, p. 414:

"Os poderes de representação são limitados aos fins sociais. Não se tem de apurar, in casu, se há fim individual da pessoa jurídica; basta que caiba no fim, tal como se exprime no registro. Aliás, quanto a 
As limitações da capacidade das pessoas jurídicas decorrem da sua própria condição ou de vedações estabelecidas por lei. Fora isso, elas figuram como sujeitos de direito nos mais variados campos do direito, podendo, até mesmo, serem responsabilizadas por ilícitos penais ${ }^{105},{ }^{106}$.

a) A Administração da Pessoa Jurídica

A pessoa jurídica, em razão de seu caráter abstrato, vale-se, necessariamente, de pessoas físicas na condição de órgãos para a prática dos atos da vida civil e celebração dos negócios do comércio jurídico, com escopo óbvio de perfazer o seu objeto social. Isso não afasta ou mitiga sua personalidade, mas tão somente decorre de sua natureza, que não lhe permite antes da constituição de seus órgãos o exercício da capacidade que lhe é conferida pelo ordenamento jurídico ${ }^{107}$.

A pessoa jurídica, assim, na consecução de suas finalidades, atua por meio de seus órgãos interna e externamente, conforme os seus atos atinjam ou não a terceiros, pessoas físicas ou também jurídicas ${ }^{108}$. E mesmo na sua atuação administrativa interna e nas

terceiros, só tem eficácia a limitação que se depreende da inscrição, inclusive se se trata do substabelecimento".

105 Lei 9605/98 - Lei dos Crimes Ambientais:

"Art. $3^{\mathbf{0}}$ - As pessoas jurídicas serão responsabilizadas administrativa, civil e penalmente conforme o disposto nesta Lei, nos casos em que a infração seja cometida por decisão de seu representante legal ou contratual, ou de seu órgão colegiado, no interesse ou benefício da sua entidade.

Parágrafo único. A responsabilidade das pessoas jurídicas não exclui a das pessoas físicas, autoras, coautoras ou partícipes do mesmo fato".

106 A. Levy, Pessoas Jurídicas - Conceito e natureza de "Órgão" nas Sociedades, Associações Civis, Fundações e Corporações, in Revista Forense, vol. XCVIII (1944), p. 231:

"A controvérsia é de grande importância para a discussão sôbre se pode haver pessoa jurídica delinqüente. A teoria orgânica delclara a pessoa jurídica capaz de agir e por conseguinte capaz de delitos. A doutrina rormana, apoiada pelo axioma de ULPIANO, nega a possibilidade de delitos e também muitos adversários das teorias fictícias romanísticas recusam reconhecer essa possibilidade. O direito alemão não decide a controvérsia, e ,sòmente regula a questão da responsabilidade da pessoa jurídica por danos. (...)".

107 F. C. Pontes de MiRAnda, Tratado de Direito Privado - Parte Geral - Tomo I - Introdução. Pessoas Físicas e Jurídicas, 4ª ed., São Paulo, RT, 1974, p. 371:

"Para cumprimento das suas funções, os órgãos têm de praticar os atos que são necessários aos fins da pessoa jurídica como se fôssem êles que os tivessem de praticar, como pessoas físicas. Os atos, praticados por êles, são da pessoa jurídica, e não dêles. Tudo isso há de obedecer às regras de constituição e organização da pessoa jurídica. A expressão 'órgãos', tomada à anátomo-fisiologia, é de grande alcance, e evita que se tenha de dilatar, com prejuízo para a técnica jurídica, o conceito de representação. Ser órgão é mais do que ser representante. Antes de ter órgãos, a pessoa jurídica não pode praticar atos. Não há pensar-se em incapacidade relativa; nem se há de cogitar de invocação analógica de regras jurídicas concernentes à incapacidade absoluta ou relativa. (...)"

108 F. C. Pontes De MiRAnda, Tratado de Direito Privado - Parte Geral - Tomo I - Introdução. Pessoas Físicas e Jurídicas, $4^{\mathrm{a}}$ ed., São Paulo, RT, 1974, pp. 371 e 372:

“À semelhança das pessoas físicas, as pessoas jurídicas têm o seu campo de atuação externa e o seu campo de atuação interna, conforme os seus atos são atinentes ou atingem terceiros, ou não lhes são atinentes, nem os atingem. Dentro ou para fora da pessoa jurídica, o órgão é sempre pessoa, ou grupo de 
relações que se estabelecem entre os diferentes órgãos da pessoa jurídica não se há jamais de pensar em representação, mas em cumprimento de deveres e obrigações impostos pelo ato constitutivo ou estatuto aos órgãos, que ao atuar atingem o patrimônio jurídico da pessoa jurídica, esta sujeito passivo dessa atuação. E perante terceiros, da mesma forma, os órgãos são a própria pessoa jurídica ${ }^{109}$.

No mesmo sentido é a lição de Caio Mário da Silva PEREIRA ${ }^{110}$ em defesa da designação de órgãos para aqueles que exercem a capacidade da pessoa jurídica, uma vez que essas pessoas físicas não são intermediárias da vontade do ente abstrato, mas expressam-na como sendo ele próprio. Lança mão, porém, da designação representação imprópria para o fenômeno, parecendo mais adequado o termo presentação.

pessoas, pelo qual atua a pessoa jurídica. Em vez de atuar em lugar dela, o órgão atua como órgão da pessoa jurídica, tornando-a presente, razão para conceitualmente e normativamente se dever evitar toda alusão à 'representação'. O órgão da pessoa jurídica presenta-a; não a representa. A mão não representa a pessoa física; nem o cérebro, nem a bôca: a mão, cérebro e bôca são órgãos. Os que repelem essas verdades são vítimas de êrro multissecular de se ver algo, que não existe, entre o ato do órgão e o ato da pessoa jurídica. Introduzir-se, aí, a idéia de representação é lançar-se mão de ficção, ou dilatar-se o conceito de representação. Quando o órgão assina a escritura pela pessoa jurídica, não representa, - é órgão da pessoa jurídica. Representante da pessoa jurídica é outra coisa. Pode bem ser que discorde, inteiramente, do que foi entabulado entre os contraentes. Não importa. Presenta, não representa. O órgão atua e tem direito a atuar, com o que se parece com o representante legal, sem ser representante legal, ainda em se tratando de pesssoa jurídica em que seja a lei que designe o órgão. (...)".

109 F. C. Pontes De MiRAnda, Tratado de Direito Privado - Parte Geral - Tomo I - Introdução. Pessoas Físicas e Jurídicas, $4^{\text {a }}$ ed., São Paulo, RT, 1974, p. 372:

"Por outro lado, na vida interna, as funções administrativas dos órgãos são irredutíveis às do representante. Tanto navida interna, quanto na externa, o órgão pode depender e depende sempre de outras vontades (e.g., a diretoria depende da assembléia geral). A idéia de representação seria, aí, ainda mais inadequada. Donde ressaltar cada vez mais a verdade da proposição: a pessoa jurídica atua por seus órgãos. Por isso, são, não só capazes de direitos, mas civil e comercialmente capazes. Não há qualquer assimilabilidade do órgão ao representante legal, nem do órgão ao representante voluntário.

Os órgãos das pessoas jurídicas têm o dever, perante elas, de cumprir os deveres e obrigações, de que são sujeitos passivos as pessoas jurídicas. Se as pessoas jurídicas faltam a tais deveres e obrigações, respondem por isso. As ações dirigem-se contra elas. As sentenças de carga suficiente de executividade executam-se contra elas. Mas, perante elas, respondem os órgãos, porque tal dever é implícito nos deveres que aos órgãos dão as leis e os estatutos".

110 Instituições de Direito Civil - Introdução ao Direito Civil - Teoria Geral do Direito Civil, vol. I, $22^{\mathrm{a}}$ ed. atualizada por Maria Celina Bodin de Moraes, Rio de Janeiro, Forense, 2007, p. 314:

"Dispõe a lei que o instrumento ou carta constitutiva da pessoa jurídica, genericamente denominado seu estatuto, designará quem a representa, e confere, portanto, a esta forma de expressão volitiva individual o poder de vontade para criar o órgão representativo. Se for omisso, caberá aos seus diretores aquela representação (Código Civil, arts. 45 e 46). Em alguns tipos de pessoas jurídicas há coincidência entre os órgãos deliberativos e os de representação; em outros, o representante participa daquele; em outros ainda a lei distingue com toda nitidez o órgão deliberativo (assembléia geral) do órgão executivo ou de representação (diretoria), facultando que deste façam parte pessoas estranhas ao corpo de associados. Moderna é a tendência de substituir a expressão representantes, que antes consagrava a doutrina e usavam os Códigos, pela expressão órgãos, atendendo a que as pessoas físicas não são meros intermediários da vontade da pessoa moral ou seus simples representantes, o que pressupõe duas vontades, a do mandante e a do procurador, mas uma só, que é a da entidade, emitida nos limites legais pelo seu elemento vivo de contato com o mundo jurídico, e constituem assim o aparelhamento técnico ou os órgãos, pelos quais manifestam a sua vontade ou exercem as suas atividades. A. substituição de uma por outra expressão tem a seu crédito a exatidão científica, pois que no órgão da pessoa jurídica não há representação técnica, porém representação imprópria, (...)”. 
Assim, o Código Civil ${ }^{111}$ cuidou de estatuir que os atos dos administradores da pessoa jurídica exercidos nos limites de poderes do ato constitutivo ou do estatuto da entidade obrigam-na e, a contrário senso, aqueles atos dos seus órgãos que exorbitarem as competências fixadas nos documentos constitutivos não são da pessoa jurídica, mas de responsabilidade das pessoas físicas que preenchem seus órgãos, que podem, nessa hipótese, ser responsabilizadas perante terceiros e até perante a própria pessoa jurídica, não se cuidando aqui do fenômeno da desconsideração da personalidade jurídica porque não se trata buscar patrimônio de membro do ente abstrato, mas de responsabilizar pessoa física que agiu mal ou em excesso na condição de órgão ${ }^{112}$.

Também ocupou-se o Código Civil ${ }^{113}$ em fixar que se a pessoa jurídica tiver administração coletiva, nada dispondo em contrário seu regramento constitutivo, as decisões se tomarão por maioria dos votos $\operatorname{presentes}^{114}$.

Ademais, previu a $\operatorname{lei}^{115}$ a possibilidade de a pessoa jurídica se tornar acéfala ${ }^{116}$, sem administração alguma, e concedeu ao juiz o poder de provê-la de um guardião provisório mediante provocação de qualquer interessado ${ }^{117}$.

111 “Art. 47 - Obrigam a pessoa jurídica os atos dos administradores, exercidos nos limites de seus poderes definido no ato constitutivo".

112 Caio Mário da Silva PereIRA, Instituições de Direito Civil - Introdução ao Direito Civil - Teoria Geral do Direito Civil, vol. I, 22 a ed. atualizada por Maria Celina Bodin de Moraes, Rio de Janeiro, Forense, 2007, pp. 314 e 315:

"Foi o que fez o Código Civil (art. 43), na linha da tendênda moderna. Como órgãos da pessoa jurídica, obriga-se esta pelos atos de seus administradores, subordinados, contudo, a se conterem nos limites traçados no ato constitutivo e suas subseqüentes alterações (art. 47). Se exorbitarem, a pessoa jurídica não é obrigada, mas respondem eles pessoalmente pelos prejuízos causados a terceiros, em razão dos abusos cometidos, hipótese que não se confunde com o do abuso que pode gerar a desconsideração da própria personalidade jurídica, (...)".

113 “Art. 48 - Se a pessoa jurídica tiver administração coletiva, as decisões se tomarão pela maioria de votos dos presentes, salvo se o ato constitutivo dispuser de modo diverso. (...)".

114 Caio Mário da Silva PereIRA, Instituições de Direito Civil - Introdução ao Direito Civil - Teoria Geral do Direito Civil, vol. I, 22 a ed. atualizada por Maria Celina Bodin de Moraes, Rio de Janeiro, Forense, 2007, p. 315:

"Agindo através de seus órgãos, as decisões serão tomadas na conformidade do que dispõe o estatuto. Sendo unipessoal a administração, cabe ao dirigente a deliberação. Se for coletiva, as decisões serão tomadas na forma do que vem disposto no ato constitutivo, quer na observância de quorum especial, quer na delegação de poderes a um ou mais administradores. É comum o estatuto exigir para certos atos a presença de mais de um, ou associar um deles a um procurador. No silêncio do ato constitutivo, o Código destacou, no art. 48, que as decisões coletivas da administração da pessoa jurídica, salvo disposição estatutária em contrário, são tomadas pela maioria dos votos dos presentes".

115 Código Civil:

“Art. 49 - Se a administração da pessoa jurídica vier a faltar, o juiz, a requerimento de qualquer interessado, nomear-lhe-á administrador provisório".

116 F. C. Pontes De MiRAnda, Tratado de Direito Privado - Parte Geral - Tomo I - Introdução. Pessoas Físicas e Jurídicas, $4^{\text {a }}$ ed., São Paulo, RT, 1974, pp. 372 e 373: 
Além de agir de per si, valendo-se de seus órgãos, a pessoa jurídica pode, outrossim, constituir mandatários, que a representarão na exata medida dos poderes que lhes forem outorgados ${ }^{118}$. Nesse ponto, a pessoa jurídica obrará valendo-se de figura distinta da de seus órgãos que a presentam. Entra-se na seara do Mandato, figura contratual legalmente prevista e disciplinada ${ }^{119}$ e da qual redunda o fenômeno da representação de uma pessoa, física ou jurídica, por outra, para determinado, ou determinados, atos específicos, sendo seu instrumento a Procuração.

Tanto numa hipótese como em outra, as questões controvertidas surgem quando administradores (órgãos), presentando, ou procuradores, representando a pessoa jurídica, agem com ausência ou excesso de poderes.

\subsection{A Transformação da Pessoa Jurídica}

Inicialmente, cabe fixar os limites da alteração das pessoas jurídicas, até para melhor compreensão do fenômeno de sua transformação ${ }^{120}$. Consiste, assim, a alteração, em mudança em seus documentos constitutivos ${ }^{121}$ não suficientemente significativas a

"A acefalia das sociedades e das fundações cria estado anormal na vida da pessoa jurídica, a que hão de prover os estatutos, ou, na falta de regra jurídica estatutária, a lei. Se regra jurídica não há, que preveja o modo de se dar solução à perplexidade, que a acefalia cria, os sistemas jurídicos contemplam ações cujas decisões chegam ao mesmo resultado de cefalização provisória, ou ao encurtamento da duração da acefalia. (...)

A acefalia resulta: $a$ ) da terminação do tempo para que foram eleitos os órgãos da pessoa jurídica, se não prevêem os estatutos que as pessoas, que eram órgãos, ou alguma ou algumas delas continuem à testa da pessoa jurídica, ou alguém assuma a direção, até que se proceda à posse dos novos eleitos; $b$ ) da morte, renúncia ou afastamento da única ou de tôdas as pessoas que teriam de ser órgão da pessoa jurídica. (...)”.

117 Caio Mário da Silva PereIRA, Instituições de Direito Civil - Introdução ao Direito Civil - Teoria Geral do Direito Civil, vol. I, 22 a ed. atualizada por Maria Celina Bodin de Moraes, Rio de Janeiro, Forense, 2007, p. 315:

"No caso de ficar acéfala a pessoa jurídica, qualquer interessado poderá tomar as medidas assecuratórias e requererá ao juiz que designe administração provisória (art. 49 do Código Civil). Esta ocupará o lugar da faltosa, até que, na forma da lei ou do estatuto, seja nomeada a definitiva. No ato de designação o juiz poderá fixar prazo ao administrador provisório, bem como estabelecer a extensão de seus poderes".

118 F. C. PONTES DE MIRANDA, Tratado de Direito Privado - Parte Geral - Tomo I - Introdução. Pessoas Físicas e Jurídicas, $4^{\text {a }}$ ed., São Paulo, RT, 1974, p. 414:

"Cumpre não se confundam os órgãos da pessoa jurídica, que são órgãos de sua vontade, tais como a diretoria e o órgão de que trata o art. 17 (órgão), e os representantes nomeados pela diretoria, ou pelos representantes-órgãos, ou pela assembléia, sem caráter de órgão (procuradores, mandatários, empregados). Se não foi designado, no ato constitutivo, o órgão, é-o a diretoria. (...)".

119 Código Civil - artigos 653 a 692.

120 Sílvio de Salvo Venosa, Direito Civil - Parte Geral, vol. 1, $3^{\text {a }}$ ed., São Paulo, Atlas, 2003,p. 296: "Embora os fenômenos ocorram mais freqüentemente com sociedades, nada impede que também associações e fundações se valham dessas formas de transformação. (...)".

121 Washington de Barros MonteIro, Curso de Direito Civil - Parte Geral, $41^{\mathrm{a}}$ ed. atualizada por Ana Cristina de Barros Monteiro França Pinto, São Paulo, Saraiva, 2007, p. 152:

"Todas as modificações que sofrerem os atos constitutivos deverão ser averbadas no registro competente, da mesma forma que os atos constitutivos (Cód. Civil de 2002, art. 45)”. 
ponto de desnaturar a pessoa jurídica existente, transformando-a em outra, ou seja, fazendo nascer um novo ente ou fazendo morrer o antes existente ${ }^{122}$.

A transformação, por seu turno, diz respeito a modificações contundentes que dão azo ao surgimento de uma nova pessoa jurídica, ao desaparecimento de uma velha ou ambos os fenômenos. Dá-se de três formas: 1) Fusão - espécie de transformação pela qual duas ou mais pessoas jurídicas já constituídas se unem, perdendo suas respectivas autonomias, e dando origem a um novo ente até então inexistente no mundo jurídico ${ }^{123} .2$ ) Incorporação - espécie de transformação pela qual uma pessoa jurídica ou mais são aglutinadas por outra que lhes sucede, sub-rogando-se em seus direitos e obrigações. Nesta modalidade de operação, não há nascimento de uma nova pessoa jurídica, mas o desaparecimento da ou das incorporadas ${ }^{124}$. 3) Cisão - é o fenômeno inverso, pelo qual uma pessoa jurídica já existente cinde-se dando origem a um novo ente e permanecendo no mundo jurídico (cisão parcial), ou cinde-se dando origem a duas ou mais novas pessoas jurídicas, com conseqüente desaparecimento do ente primário (cisão total) ${ }^{125}$.

Ainda no tocante às hipóteses de transformação das pessoas jurídicas de direito privado, a que este tópico ficou restrito, merece menção a possibilidade de fusão de sociedades de economia mista, de acordo Sílvio MARCONDES ${ }^{126}$.

122 Sílvio de Salvo Venosa, Direito Civil - Parte Geral, vol. 1, $3^{\text {a }}$ ed., São Paulo, Atlas, 2003, p. 296: "Alteração é mudança de cláusula no estatuto ou contrato social, enquanto transformação é operação de maior escala, equivalendo a fazer desaparecer uma pessoa jurídica e para surgir outra".

123 Sílvio de Salvo VenosA, Direito Civil-Parte Geral, vol. 1, $3^{\text {a }}$ ed., São Paulo, Atlas, 2003, p. 296:

"É também forma de transformação a fusão de pessoas jurídicas. Ocorre quando duas ou mais entidades perdem sua personalidade autônoma, para transformarem uma pessoa jurídica diversa, com personalidade diferente das anteriores. (...) O novo Código dispõe: 'A fusão determina a extinção das sociedades que se unem, para formar sociedade nova, que a elas sucederá nos direitos e obrigações' (art. 1.119). Estabelece-se uma nova pessoa jurídica, sem que haja liquidação das primitivas".

124 Sílvio de Salvo VenosA, Direito Civil-Parte Geral, vol. 1, $3^{\text {a }}$ ed., São Paulo, Atlas, 2003, p. 296 :

"A incorporação tem no vernáculo a noção de inclusão, união, ligação de uma coisa a outra. Para o Direito Empresarial, do qual nos devemos valer, o fenômeno tem essa noção: é a operação pela qual uma ou mais pessoas jurídicas são absorvidas por outra que lhes sucede em direitos e obrigações. Há integração de uma pessoa em outra, desaparecendo a pessoa absorvida. O novo Código Civil, que passa a tratar da empresa, assim conceitua: 'Na incorporação, uma ou várias sociedades são absorvidas por outra, que lhes sucede em todos os direitos e obrigações, devendo todas aprová-la, na forma estabelecida para os respectivos tipos' (art. 1.116)".

125 Sílvio de Salvo VenosA, Direito Civil-Parte Geral, vol. 1, $3^{\text {a }}$ ed., São Paulo, Atlas, 2003, p. 297 :

"Na cisão, o fenômeno é inverso. A pessoa jurídica divide-se, fraciona-se em duas ou mais pessoas. (...) Na cisão, que pode ser total ou parcial, a empresa cindida continua a existir ou extingue-se. A cisão pode também ser denominada fracionamento ou desmembramento".

126 In Problemas de Direito Mercantil, São Paulo, Max Limonad, 1970, pp. 409-426. 


\subsection{A Desconsideração da Pessoa Jurídica}

Ao longo do tempo, percebeu-se que a autonomia patrimonial da pessoa jurídica em relação aos seus membros, característica fundamental dos entes abstratos ${ }^{127}$, era subterfúgio para fraudes e abusos. A realidade conduziu à idéia de que a pessoa jurídica era, também, anteparo para burla à lei e escudo para não cumprimento de obrigações ${ }^{128}$.

Constatada essa distorção, que acometia as pessoas jurídicas, cuidou a ciência jurídica, num primeiro momento, por meio da jurisprudência norte-americana ${ }^{129}$, e num segundo momento, por meio da doutrina alema ${ }^{130}$, de providenciar o necessário remédio ${ }^{131}$.

127 Rubens REQUĩ̃o, Abuso de Direito e Fraude através da Personalidade Jurídica, in Revista dos Tribunais, 410 (1969), p. 15:

"Ora, uma das mais decisivas conseqüências da concessão da personalidade jurídica, outorgada pela lei, todos o sabemos, é a sua autonomia patrimonial, tornando a responsabilidade dos sócios estranha à responsabilidade social, e mesmo quando se trate de sócio com responsabilidade ilimitada e solidária é sempre ela subsidiária”.

128 Caio Mário da Silva PereIRA, Instituições de Direito Civil - Introdução ao Direito Civil - Teoria Geral de Direito Civil, vol. I, 22 ${ }^{\mathrm{a}}$ ed. atualizada por Maria Celina Bodin de Moraes, Rio de Janeiro, Forense, 2007, pp. 333 e 334:

"Distinguindo a responsabilidade do ente moral relativamente aos seus integrantes - societas distat a singulis -, acobertavam-se eles (e muito particularmente os seus administradores) de todas as conseqüências, salvo nos casos de individualmente incorrerem em falta.

Modernamente, entretanto, o desenvolvimento da sociedade de consumo, a coligação de sociedades mercantis e o controle individual de grupos econômicos têm mostrado que a distinção entre sociedade e seus integrantes, em vez de consagrar regras de justiça social, tem servido de cobertura para a prática de atos ilícitos, de comportamentos fraudulentos, de absolvição de irregularidades, de aproveitamentos injustificáveis, de abusos de direito. Os integrantes da pessoa jurídica invocam o princípio da separação, como se tratasse de um véu protetor. Era preciso criar um instrumento jurídico hábil a ilidir os efeitos daquela cobertura.

129 Caio Mário da Silva PereIRA, Instituições de Direito Civil - Introdução ao Direito Civil - Teoria Geral de Direito Civil, vol. I, $22^{\mathrm{a}}$ ed. atualizada por Maria Celina Bodin de Moraes, Rio de Janeiro, Forense, 2007, p. 334:

"Sentindo os inconvenientes desta imunidade, o direito norte-americano, engendrou a doutrina da disregard of legal entity, segundo a qual se deve desconsiderar a pessoa jurídica quando, em prejuízo de terceiros, houver por parte dos órgãos dirigentes a prática de ato ilícito, ou abuso de poder, ou violação de norma estatutária ou, genericamente, infração de disposição legal.

(...) Em oposição, portanto, à velha regra societas distat a singulis, uma nova concepção foi construída. De fato, a desconsideração da pessoa jurídica consiste em que, nas circunstâncias previstas, o juiz deixa de aplicar a mencionada regra tradicional da separação entre a sociedade e seus sócios, segundo a qual é a pessoa jurídica que responde pelos danos e os sócios nada respondem”.

130 Caio Mário da Silva PereIRA, Instituições de Direito Civil - Introdução ao Direito Civil - Teoria Geral de Direito Civil, vol. I, 22a ed. atualizada por Maria Celina Bodin de Moraes, Rio de Janeiro, Forense, 2007, p. 335:

"Partindo da análise de decisão da Corte americana, o Prof. Rolf Serick, com a habitual minúcia dos juristas alemães, enunciou que muitas vezes a estrutura formal da pessoa jurídica é utilizada como escudo protetor de comportamento abusivo ou irregular de uma pessoa, sob a aparência de se valer da proteção da norma jurídica. (...)."

131 Caio Mário da Silva PereIRA, Instituições de Direito Civil - Introdução ao Direito Civil - Teoria Geral de Direito Civil, vol. I, $22^{\mathrm{a}}$ ed. atualizada por Maria Celina Bodin de Moraes, Rio de Janeiro, Forense, 2007, pp. 334 e 335:

"O que neste sentido ocorreu foi que se elaborou uma doutrina de sustentação para, levantando o véu da pessoa jurídica, alcançar aquele que, em fraude à lei ou ao contrato, procurou eximir-se por trás da 
Sem jogar por terra o princípio da autonomia patrimonial e muito menos colocar em xeque o próprio instituto da personalidade jurídica ${ }^{132},{ }^{133}$, mas relativizando-os ${ }^{134} \mathrm{e}$ aperfeiçoando-os ${ }^{135}$, a ciência jurídica criou a "Teoria da Desconsideração da Personalidade Jurídica".

No Brasil, a teoria foi introduzida em 1969 pelo Professor RUBENS REQUĩ̃o ${ }^{136}$, quando publicou, na Revista dos Tribunais, Conferência proferida na Faculdade de Direito

personalidade jurídica e escapar, fazendo dela uma simples fachada para ocultar uma situação danosa. A denominada disregard doctrine significa, na essência, que em determinada situação fática, a Justiça despreza ou 'desconsidera' a pessoa jurídica, visando a restaurar uma situação em que chama à responsabilidade e impõe punição a uma pessoa física, que seria o autêntico obrigado ou o verdadeiro responsável, em face da lei ou do contrato".

132 Rubens REQUIÃO, Abuso de Direito e Fraude através da Personalidade Jurídica, in Revista dos Tribunais, 410(1969), p.17:

"Mas, convém explicar, no que se refere à <<disregard doctrine>>, que contribui ela para pôr ainda mais a nu a crise no conceito normativo da pessoa jurídica, embora tivesse advertido o Prof. Serick que não era êsse o objetivo de seu trabalho. Disse êle, ao revés, que <<quando emprega a frase desestimação da forma da pessoa jurídica (<<Missachtung der Rechtform der Juristischen Person>>), deve entender-se que com isso só se trata da desestimação da forma da pessoa jurídica no caso particular, sem negar sua personalidade de u'a maneira geral >>. Com efeito, o que se pretende, com a doutrina do <<disregard >> não é a anulação da personalidade jurídica em tôda a sua extensão, mas apenas a declaração de sua ineficácia para determinado efeito, em caso concreto, em virtude de o uso legítimo da personalidade ter sido desviado de sua legítima finalidade (abuso de direito) ou para prejudicar credores ou violar a lei (fraude). (...)".

133 Caio Mário da Silva PereIRA, Instituições de Direito Civil - Introdução ao Direito Civil - Teoria Geral de Direito Civil, vol. I, 22 a ed. atualizada por Maria Celina Bodin de Moraes, Rio de Janeiro, Forense, 2007, p. 335:

"Cumpre observar, todavia, que não se trata de decretar a nulidade ou a desconstituição da pessoa jurídica, senão, em dadas circunstâncias, proclamar-lhe a ineficácia, continuando a personalidade jurídica a subsistir para todo e qualquer ato".

134 Rubens REQUIÃo, Abuso de Direito e Fraude através da Personalidade Jurídica, in Revista dos Tribunais, 410 (1969), p. 15:

"Ora, a doutrina da desconsideração nega precisamente o absolutismo do direito da personalidade jurídica. Desestima a doutrina êsse absolutismo, perscruta através do véu que a encobre, penetra em seu âmago, para indagar de certos atos dos sócios ou do destino de certos bens. Apresenta-se, por conseguinte, a concessão da personalidade jurídica com um significado ou um efeito relativo, e não absoluto, permitindo a legítima penetração inquiridora em seu âmago.

Ora, assim há de ser. Se a personalidade jurídica constitui uma criação da lei, como concessão do Estado objetivando, como diz Cunha Gonçalves, <<a realização de um fim >> nada mais procedente do que se reconhecer que ao Estado, através de sua justiça, a faculdade de verificar se o direito concedido está sendo adequadamente usado. A personalidade jurídica passa a ser considerada doutrinariamente um direito relativo, permitindo ao juiz penetrar o véu da personalidade para coibir abusos ou condenar a fraude, através de seu uso".

135 Fábio Ulho Coelho, Curso de Direito Civil, vol. 1, $2^{\text {a }}$ ed., São Paulo, Saraiva, 2006, pp. 243 e 244 : "A teoria da desconsideração da pessoa jurídica (ou do superamento da personalidade jurídica) não questiona o princípio da autonomia patrimonial, que continua válido e eficaz ao estabelecer que, em regra, os membros da pessoa jurídica não respondem pelas obrigações desta. Trata-se de aperfeiçoamento da teoria da pessoa jurídica, através da coibição do mau uso de seus fundamentos. Assim, a pessoa jurídica desconsiderada não é extinta, liquidada ou dissolvida pela desconsideração; não é igualmente, invalidada ou desfeita. Apenas determinados efeitos de seus atos constitutivos deixam de se produzir episodicamente. Em outras palavras, a separação patrimonial decorrente da constituição da pessoa jurídica não será eficaz no episódio da repressão à fraude. Para todos os demais efeitos, a constituição da pessoa jurídica é existente, válida e plenamente eficaz. (...)".

136 Rubens REQUĩ̃o, Abuso de Direito e Fraude através da Personalidade Jurídica, in Revista dos Tribunais, 410 (1969), p. 13: 
da Universidade Federal do Paraná, por ocasião das comemorações do primeiro centenário de nascimento do Des. Vieira Cavalcanti Filho, fundador e primeiro catedrático de Direito Comercial daquela instituição de ensino.

Sua sistematização, porém, deu-se nos idos anos da década de 1950, na tese de R. SERICK, “Aparencia y Realidad em las Sociedades Mercantiles - El Abuso de Derecho por Medio de la Persona Jurídica" ${ }^{\text {137 }}$, apresentada para conquista do título de Privat-Dozent da Universidade de Tübingen.

A teoria tem o objetivo de impedir a fraude e o abuso por meio da autonomia patrimonial da pessoa jurídica, desconsiderando o seu véu protetor no caso concreto em que se verificam tais ocorrências e atingindo o patrimônio pessoal daqueles que se escondem atrás do ente abstrato ${ }^{138}$.

Rubens REQUIÃO, em seu estudo pioneiro, elege como motivos para a desconsideração da personalidade jurídica a fraude e o abuso de direito ${ }^{139}$. Define a fraude $^{140}$ como o uso da pessoa jurídica para contornar vedações estatutárias do exercício

"Não temos lembrança, em nossas constantes peregrinações pelas páginas do direito comercial pátrio, de haver encontrado doutrina nacional ou estudos sôbre o uso abusivo ou fraudulento da pessoa jurídica, o que nos daria, se correta nossa impressão, o júbilo de apresentá-la pela primeira vez, em sua formulação sistemática, aos colegas e aos juristas nacionais, realçando, só por isso, a nossa frágil e modesta participação nestas homenagens <<in memorian〉> do Prof. Vieira Cavalcanti Filho".

137 Abuso de Direito e Fraude através da Personalidade Jurídica, in Revista dos Tribunais, 410 (1969), p. 13:

"Êsse livro, tese de concurso com que o professor Rolf Serick germânico conquistara cêrca dedez anos o título de <<Privat-Dozent >>, na Universidade de Tübingen, vinha traduzido para o castelhano por um jurista catalão, José Puig Brutau, sob o patrocínio do Seminário da Cátedra de Direito Mercantil da Universidade de Barcelona, sendo apresentado pelo catedrático Prof. Polo Diez. (...)”.

138 Rubens REQUĩ̃o, Abuso de Direito e Fraude através da Personalidade Jurídica, in Revista dos Tribunais, 410 (1969), p. 13:

"A doutrina desenvolvida pelos tribunais norte-americanos, da qual partiu o Prof. Rolf Serick para compará-la com a moderna jurisprudência dos tribunais alemães, visa a impedir a fraude ou abuso através do uso da personalidade jurídica, e é conhecida pela designação <<disregard of legal entity>> ou também pela $<<$ lifting the corporate veil >>. Com permissão dos mais versados no idioma inglês, acreditamos que não pecaríamos se traduzíssemos as expressões referidas como $<<$ desconsideração da personalidade jurídica $>>$, ou ainda, como $<<$ desestimação da personalidade jurídica $>>$, correspondente à versão espanhola que lhe deu o Prof. Polo Diez, ou seja, <<desestimación de La personalidad jurídica $>$. $O<<$ lifting the corporate veil $\gg>$ seria o <<levantamento do véu corporativo $>$, ou da $<<$ personalidade jurídica $>>$. (...)".

139 Rubens REQUião, Abuso de Direito e Fraude através da Personalidade Jurídica, in Revista dos Tribunais, 410 (1969), p. 14:

"Ora, diante do abuso de direito e da fraude no uso da personalidade jurídica, o juiz brasileiro tem o direito de indagar, em seu livre convencimento, se há de consagrar a fraude ou o abuso de direito, ou se deva desprezar a personalidade jurídica, para, penetrando em seu âmago, alcançar as pessoas e bens que dentro dela se escondem para fins ilícitos ou abusivos".

140 Rubens REQUĩ̃o, Abuso de Direito e Fraude através da Personalidade Jurídica, in Revista dos Tribunais, 410 (1969), p. 12: 
do comércio ou outras proibições legais e o abuso de direito ${ }^{141}$ como sendo não, propriamente, o ato atentatório à ordem legal, mas o exercício inadequado e ao arrepio de sua função social de determinado direito.

Carlos Alberto MenEZES DiREITO ${ }^{142}$ comunga do mesmo entendimento de que os motivos ensejadores da desconsideração sejam o abuso e a manipulação fraudulenta da autonomia patrimonial, com o fim escuso de não observar a lei ou não honrar obrigações assumidas, resguardando, sempre, a perenidade da pessoa jurídica, que teve seu véu protetor momentânea, casuística e circunstancialmente levantado. Lembra, outrossim, a possibilidade de desconsideração a fim de responsabilizar a pessoa jurídica por obrigações do seu integrante ${ }^{143}$.

"Todos percebem que a personalidade jurídica pode vir a ser usada como anteparo de fraude, sobretudo para contornar proibições estatutárias do exercício de comércio ou outras vedações legais. (...)”.

141 Rubens ReQuĩ̃o, Abuso de Direito e Fraude através da Personalidade Jurídica, in Revista dos Tribunais, 410 (1969), pp. 15 e 16:

"Para se compreender a fundo a teoria do abuso de direito, deve-se partir da observação de Josserand de que se a sociedade garante a determinadas pessoas as suas prerrogativas, não é para ser-lhes agradável, mas para assegura-lhes a própria conservação. Êsse é, na verdade, o mais alto atributo do Direito: a sua finalidade social. (...)

O direito, enfim, foi criado em atenção ao indivíduo, tendo por objetivo ordenar sua convivência com outros indivíduos. O exercício de seus direitos, embora privados, deve atender a uma finalidade social. A função social do direito, que se refere sobretudo aos contratos e à propriedade, deve, pelo indivíduo ser atendida.

Assim, o sujeito não exercitará seus direitos egoisticamente, mas tendo em vista a função dêles, a finalidade social que objetivam. $\mathrm{O}$ ato, embora conforme a lei, se fôr contrário a essa finalidade, é abusivo e, em consequiência, atentatório ao direito. Nem tudo que é conforme a lei é legítimo, eis o postulado fundamental da teoria de Josserand. (...)

Ora, como se vê, não há porque confundir a teoria do abuso de direito coma a do ato ilícito, ou, mais particularmente, com a fraude. Considera-se ato fraudulento, como conceituam os revisores do Projeto de Código de Obrigações, no art. 67, <<o negócio jurídico tramado para prejudicar credores, em benefício do declarante ou de terceiro >>. No abuso de direito não existe, pròpriamente, trama contra $o$ direito de credor, mas surge do inadequado uso de um direito, mesmo que seja estranho ao agente o propósito de prejudicar o direito de outrem".

142 A desconsideração da Personalidade Jurídica, in ARruda Alvim, Joaquim Portes De Cerqueira CÉSAR e Roberto Rosas (coords.), Aspectos Controvertidos do Novo Código Civil - Escritos em Homenagem ao Ministro José Carlos Moreira Alves, São Paulo, RT, 2003, p. 88:

"A meu sentir, no plano doutrinário, a desconsideração da personalidade jurídica cabe quando houver a configuração de abuso ou de manipulação fraudulenta do princípio da separação patrimonial entre a sociedade e seus membros. O que se quer é evitar a manipulação da autonomia patrimonial da sociedade como meio de impedir, fraudulentamente, o resgate de obrigação assumida nos termos da lei. $\mathrm{E}$, assim mesmo, a doutrina não conduz à extinção da sociedade, que permanece existindo regularmente, mas, tão-somente, afasta a separação patrimonial em uma determinada circunstância. (...)".

143 Carlos Alberto MENEZES DIREITO, A desconsideração da Personalidade Jurídica, in ARRUDA Alvim, JoAquim Portes de CERQueira César e Roberto Rosas (coords.), Aspectos Controvertidos do Novo Código Civil - Escritos em Homenagem ao Ministro José Carlos Moreira Alves, São Paulo, RT, 2003, p. 89:

"Como sabido, o objetivo maior da desconsideração da personalidade jurídica é responsabilizar o sócio por dívida formalmente imputada à sociedade. Mas isso não quer dizer que não possa ocorrer o 
E finalmente, Sílvio RoDRIGUES ${ }^{144}$ perfilha também do mesmo conceito, destacando que incide a desconsideração quando se verifica a fraude e o abuso com escopo de ferir direitos alheios ou do fisco, enganar credores, escapar da observância da lei ou proteger ato desonesto.

Da mesma forma, os autores ${ }^{145}$ que discorreram sobre a "Teoria da Desconsideração da Personalidade Jurídica" buscados neste trabalho, forma uníssona, alertam para excepcionalidade da aplicação da doutrina e a necessidade de cautela para sua invocação. Vale registrar, ao cabo, a admoestação de RUBENS REQUIÃO ${ }^{146}$ ao introduzir a Disregard Doctrine no Brasil:

"É preciso, para a invocação exata e adequada da doutrina, repelir a idéia preconcebida dos que estão imbuídos do fetichismo da intocabilidade da pessoa jurídica, que não pode ser equiparada tão

contrário, ou seja, o afastamento da autonomia patrimonial para responsabilizar a sociedade por dívida do sócio, desde que caracterizada a manipulação fraudulenta”.

144 Direito Civil - Parte Geral, vol. 1, 34ª ed., São Paulo, Saraiva, 2007, pp. 96 e 97:

"Essa concepção desenvolvida por alguns tribunais americanos e alemães é conhecida naquele primeiro país pela denominação de disregard theory ou disregard of the legal entity, ou ainda pela locução lifting the corporate veil, ou seja, erguendo-se a cortina da pessoa jurídica. O que pretendem os adeptos doutrina é justamente permitir ao juiz erguer o véu da pessoa jurídica, para verificar o jogo de interesses que se estabeleceu em seu interior, com o escopo de evitar o abuso e a fraude que poderiam ferir os direitos de terceiros e o Fisco. Assim sendo, quando se recorre à ficção da pessoa jurídica para enganar credores, para fugir à incidência da lei ou para proteger um ato desonesto, deve o juiz esquecer a idéia de personalidade jurídica para considerar os seus componentes como pessoas físicas e impedir que por meio do subterfúgio prevaleça o ato fraudulento".

145 Caio Mário da Silva PereIRA, Instituições de Direito Civil - Introdução ao Direito Civil - Teoria Geral de Direito Civil, vol. I, 22 a ed. atualizada por Maria Celina Bodin de Moraes, Rio de Janeiro, Forense, 2007, p. 335:

"Merece atenção também o fato de que a doutrina da 'desconsideração' não pode ser aplicada indistintamente, mas deve ser utilizada em circunstâncias especiais, como se verá em seguida. Para acentuar a sal excepcionalidade basta recordar que o tratadista Guido Alpa (que parece demasiadamente restritivista) sustenta que somente em caso de 'abuso de direito' é possível romper o véu - lacerate Il velo - para sancionar o comportamento ilícito, ou sujeitar às normas do Código as pessoas que pretendem se ocultar sob a capa da pessoa jurídica".

Carlos Alberto Menezes DiReITo, A desconsideração da Personalidade Jurídica, in ARRUdA AlviM, JOAQUim PORTES DE CERQUEIRA CÉSAR E RoberTo RosAs (coords.), Aspectos Controvertidos do Novo Código Civil - Escritos em Homenagem ao Ministro José Carlos Moreira Alves, São Paulo, RT, 2003, p. 88:

"O que se deve considerar no trato da doutrina da desconsideração da personalidade jurídica é a sua utilização apenas para evitar o abuso ou a fraude, todas as vezes que a personalidade jurídica comercial, na forma do art. 20 do CC de 1916, for utilizada como instrumento para prestigiar aquele que manipula a pessoa jurídica com o objetivo de fugir do adimplemento de uma dada obrigação. (...)".

Sílvio Rodrigues, Direito Civil - Parte Geral, vol. 1, 34ª ed., São Paulo, Saraiva, 2007, p. 97:

"Embora me pareça útil a eventual invocação dessa concepção,mesmo fora dos casos em que a lei ordena, acho que Lea só deve sê-lo em hipóteses excepcionais, pois, ao contrário, se passasse a ser procedimento rotineiro, iria negar-se vigência ao princípio básico da teoria da personalidade jurídica, consagrado no art. 20 do antigo Código Civil, segundo o qual a pessoa jurídica tem existência distinta da de seus membros".

146 Rubens REQUĩ̃o, Abuso de Direito e Fraude através da Personalidade Jurídica, in Revista dos Tribunais, 410 (1969), p. 24. 
insòlitamente à pessoa humana no desfrute dos direitos incontestáveis da personalidade; mas também não devemos imaginar que a penetração do véu da personalidade jurídica e a desconsideração da pessoa jurídica se tornem instrumento dócil nas mãos inábeis dos que, levados ao exagêro, acabassem por destruir o instituto da pessoa jurídica, construído através dos séculos pelo talento dos juristas dos povos civilizados, em cuja galeria sempre há de ser iluminada a imagem genial de Teixeira de Freitas, que, no século passado, precedendo a muitos, fixou em nosso direito a doutrina da personalidade jurídica".

\section{O atual Código Civil cuidou do tema da Desconsideração da Personalidade Jurídica} em seu art. $50^{147}$, preferindo legislar pela exceção, ao contrário do que fazia o antigo Código de 1916, em seu art. 20 148 , que regrava, justamente, a autonomia patrimonial da pessoa jurídica ${ }^{149}$. Fábio UlHOA COELHO ${ }^{150}$, ao comentar o dispositivo, explica o desvio de

147 Código Civil:

"Art. 50 - Em caso de abuso da personalidade jurídica, caracterizado pelo desvio de finalidade, ou pela confusão patrimonial, pode o juiz decidir, a requerimento da parte, ou do Ministério Público quando lhe couber intervir no processo, que os efeitos de certas e determinadas relações de obrigações sejam estendidos aos bens particulares dos administradores ou sócios da pessoa jurídica"

148 Código Civil de 1916:

"Art. 20 - As pessoas jurídicas tem existência distinta da dos seus membros.

$\S 1^{\circ}$ - Não se poderão constituir, sem prévia autorização, as sociedades, as agências ou os estabelecimentos de seguros, montepio e caixas econômicas, salvo as cooperativas e os sindicatos profissionais e agrícolas, legalmente organizados.

Se tiverem de funcionar no Distrito Federal, ou em mais de um Estado, ou em territórios não constituídos em Estados, a autorização será do Governo Federal; se em um só Estado, do governo deste. $\S 2^{\circ}$ - As sociedades enumeradas no art. 16 , que, por falta de autorização ou de registro, se não reputarem pessoas jurídicas, não poderão acionar a seus membros, nem a terceiros; mas estes poderão responsabilizá-las por todos os seus atos".

149 Carlos Alberto Menezes DiReITo, A desconsideração da Personalidade Jurídica, in ARruda Alvim, JOAQuim PoRTES DE CERQueIra CÉSAR E Roberto Rosas (coords.), Aspectos Controvertidos do Novo Código Civil - Escritos em Homenagem ao Ministro José Carlos Moreira Alves, São Paulo, RT, 2003, pp. 93 e 94 :

“(...) Como se pode observar, o Código Civil revogado disciplinou a regra geral da separação, deixando para a jurisprudência e para as leis extravagantes o tratamento das respectivas exceções. No atual diploma, abriu-se o campo de aplicação, indicando os requisitos que autorizam o Juiz, a requerimento da parte, ou do Ministério Público quando lhe couber intervir no processo, a decidir 'que os efeitos de certas e determinadas relações de obrigações sejam estendidas aos bens particulares dos administradores ou sócios da pessoa jurídica. De fato, o novo Código afastou o rigor da regra geral presente no Código anterior para evitar a prática do abuso, 'caracterizado pelo desvio de finalidade, ou pela confusão patrimonial', que deu margem a manobras destinadas a acobertar o não-cumprimento de obrigações assumidas contratualmente ou determinadas judicialmente. A meu sentir, ficou claro e objetivo da regra, qual seja reprimir os abusos antes cometidos à sombra da separação de responsabilidade entre a pessoa jurídica e os seus membros".

150 Curso de Direito Civil, vol. 1, $2^{\mathrm{a}}$ ed., São Paulo, Saraiva, 2006, p. 244 :

"A contemplar a teoria da desconsideração da personalidade jurídica, o Código Civil estabeleceu que o abuso da forma se caracteriza pelo desvio de finalidade ou pela confusão patrimonial (CC, art. 50). Desse modo, se o sócio envolve a sociedade em negócios estranhos aos seus fins ou não separa rigorosamente os patrimônios dela e o seu, verifica-se o abuso da personalidade jurídica da sociedade. Também se caracteriza o abuso nessas hipóteses se, em vez de sócio e sociedade, tratar-se de associado 
finalidade e a confusão patrimonial como sendo o envolvimento da pessoa jurídica em desideratos estranhos às suas finalidades e a não separação rigorosa dos patrimônios do ente abstrato e dos seus integrantes.

A opção do legislador do Código de 2002 veio ao encontro ${ }^{151}$ de outros diplomas legais ${ }^{152}$ que já adotavam, no direito brasileiro, a Diregard Doctrine como forma de coibir abusos e punir fraudes levados a cabo sob o manto protetor da personalidade jurídica.

e associação ou instituidor e fundação. Também podem abusar da personalidade da pessoa jurídica, desviando sua finalidade ou confundindo patrimônios, independentemente da espécie, os representantes legais ou administradores dela".

151 Enunciado 51 do CEJ:

"A teoria da desconsideração da personalidade jurídica, - 'diregard doctrine' - fica positivada no novo Código Civil, mantidos os parâmetros existentes nos microssistemas legais e na construção jurídica sobre o tema".

152 CDC (art. 28), CTN (art. 135), CLT (art. $2^{\circ}, \S^{\circ}$ ), Lei 9.605/98 (Lei Ambiental - art. $4^{\circ}$ ) e Lei 8.884/94 (Lei do CADE - art. 18):

CDC - Art. 28 - O juiz poderá desconsiderar a personalidade jurídica da sociedade quando, em detrimento do consumidor, houver abuso de direito, excesso de poder, infração da lei, fato ou ato ilícito ou violação dos estatutos ou contrato social. A desconsideração também será efetivada quando houver falência, estado de insolvência, encerramento ou inatividade da pessoa jurídica provocados por má administração.

(...)

$\S 2^{\circ}$ As sociedades integrantes dos grupos societários e as sociedades controladas, são subsidiariamente responsáveis pelas obrigações decorrentes deste código.

$\S 3^{\circ}$ As sociedades consorciadas são solidariamente responsáveis pelas obrigações decorrentes deste código.

$\S 4^{\circ}$ As sociedades coligadas só responderão por culpa.

$\S 5^{\circ}$ Também poderá ser desconsiderada a pessoa jurídica sempre que sua personalidade for, de alguma forma, obstáculo ao ressarcimento de prejuízos causados aos consumidores.

CTN - Art. 135 - São pessoalmente responsáveis pelos créditos correspondentes a obrigações tributárias resultantes de atos praticados com excesso de poderes ou infração de lei, contrato social ou estatutos:

I - as pessoas referidas no artigo anterior;

II - os mandatários, prepostos e empregados;

III - os diretores, gerentes ou representantes de pessoas jurídicas de direito privado.

CLT - Art. $2^{\circ}$ - Considera-se empregador a empresa, individual ou coletiva, que, assumindo os riscos da atividade econômica, admite, assalaria e dirige a prestação pessoal de serviço.

$\S 1^{\circ}$ - Equiparam-se ao empregador, para os efeitos exclusivos da relação de emprego, os profissionais liberais, as instituições de beneficência, as associações recreativas ou outras instituições sem fins lucrativos, que admitirem trabalhadores como empregados.

$\S 2^{\circ}$ - Sempre que uma ou mais empresas, tendo, embora, cada uma delas, personalidade jurídica própria, estiverem sob a direção, controle ou administração de outra, constituindo grupo industrial, comercial ou de qualquer outra atividade econômica, serão, para os efeitos da relação de emprego, solidariamente responsáveis a empresa principal e cada uma das subordinadas.

Lei 9.605/98 - Art. $4^{\circ}$ - Poderá ser desconsiderada a pessoa jurídica sempre que sua personalidade for obstáculo ao ressarcimento de prejuízos causados à qualidade do meio ambiente.

Lei 8.884/94 - Art. 18 - A personalidade jurídica do responsável por infração da ordem econômica poderá ser desconsiderada quando houver da parte deste abuso de direito, excesso de poder, infração da lei, fato ou ato ilícito ou violação dos estatutos ou contrato social. A desconsideração também será efetivada quando houver falência, estado de insolvência, encerramento ou inatividade da pessoa jurídica provocados por má administração. 
Finalmente, sob o aspecto doutrinário, cabe informar que a teoria da desconsideração evoluiu e alargou-se no Brasil, com relevantes trabalhos como os de FÁBIO KONDER COMPARATO ${ }^{153}$ e José LAMARTINE CORRÊA DE OLIVEIRA ${ }^{154}$.

\subsection{A Morte da Pessoa Jurídica}

Já no direito romano, figurava como atributo positivo das pessoas jurídicas sua longevidade em relação à duração da pessoa natural. Assim, por exemplo, a morte de seus integrantes, desde que restasse pelo menos um, não era motivo para a sua extinção. Por outro lado, o direito cuidava das hipóteses em que a pessoa jurídica sucumbia: a) morte, renúncia, ou deliberação de todos os seus integrantes pela sua extinção; b) alcance ou impossibilidade de atingir seu escopo; c) fim do prazo de duração, quando definido seu termo e d) ato do Estado Romano que retirava a autorização de funcionamento, por reputar nociva sua atuação. Nessas hipóteses, o destino de seus bens dependia do disposto em seus estatutos ou na lei que dissolvia a entidade, quando era extinta por determinação do Estado Romano. Já sendo silentes a lei ou o estatuto, divergem os romanistas se os bens destianavam-se ao Estado, por serem considerados vacantes, ou se eram distribuídos entre os associados, sendo certo que as fontes não permite assegurar nenhuma das soluções ${ }^{155}$.

No direito moderno, assim como a pessoa física, também a pessoa jurídica tem o seu ocaso, a sua morte. Não lhe prevalece, porém, o brocardo mors ominia solvit, ou seja, a sua morte não é instantânea e com completa solução de seu patrimônio jurídico ${ }^{156},{ }^{157}$.

153 Fábio Konder COMParato, O Poder de Controle na Sociedade Anônima, $2^{\mathrm{a}}$ ed. texto refundido e adaptado às disposições da Lei n. 6.404, de 15.12.76, São Paulo, RT, 1977.

154 J. Lamartine CorrêA De OliveIRA, A Dupla Crise da Pessoa Jurídica, São Paulo, Saraiva, 1979.

155 J. C. MoReIRA Alves, Direito Romano, vol. 1, $13^{\mathrm{a}}$ ed., Rio de Janeiro, Forense, 2003, p. 136:

"Se a corporação não se extingue com a morte de seus associados desde que haja a sua substituição por outros (essa, aliás, uma das vantagens da pessoa jurídica: a de sobreviver às pessoas físicas que a constituem), ou desde que reste um só deles (para constituição da associação, como vimos, são necessárias três pessoas físicas; mas para que ela continue a viver, basta uma), é certo também que se extingue por qualquer das seguintes causas: $a$ ) morte, renúncia, ou deliberação de todos os associados; $b$ ) ter atingido o fim a que ela se propunha; $c$ ) ter-se tornado impossível seu escopo; $d$ ) escoamento do prazo de sua duração, quando constituída para existir por tempo certo; e $e$ ) ato do Estado que lhe cassava a autorização de funcionar, por julgar nociva sua atuação.

Extinta a corporação, qual o destino de seus bens? A esse respeito, era de observar-se a lei que dissolvia a associação, quando ela se extinguira pela cassação por parte do Estado, ou, quando essa hipótese não ocorria, o que determinava os seus estatutos, a propósito. Quando nem a lei, nem os estatutos disciplinavam o destino dos bens da associação depois de extinta, divergem os romanistas sobre qual seria a destinação desses bens. Alguns entendem que eles, nesse caso, caberiam ao Estado (por serem considerados bens vacantes, isto é, lens sem dono); outros julgam que eram eles divididos entre os associados. O que é certo é que os textos não oferecem base sólida para nenhuma das duas soluções, embora a segunda seja mais plausível do que a primeira". 
Várias são as hipóteses de extinção das pessoas jurídicas, não cuidando, porém, o atual Estatuto Civil de prevê-las. O velho Código Civil de 1916, ao contrário, em seu art. 21, previa expressamente quando terminava a existência da pessoa jurídica: "I - pela dissolução, deliberada entre os seus membros, salvo o direito da minoria e de terceiros; II pela dissolução, quando a lei determine; III - pela sua dissolução em virtude de ato do Governo, que lhe casse a autorização para funcionar, quando a pessoa jurídica incorra em atos opostos aos seus fins ou nocivos ao bem público".

Já foram mencionadas a fusão, procedimento que ocasiona a morte das pessoas jurídicas originárias que se unem para dar vida a uma nova, a incorporação, pela qual a pessoa jurídica incorporada deixa o mundo jurídico para se subsumir à incorporadora e a cisão total, que fulmina a velha pessoa jurídica e dá vida às suas sucessoras.

O Código Civil ${ }^{158}$ ocupou-se em em disciplinar o procedimento de extinção da pessoa jurídica, que, em linhas gerais, percorre o caminho da dissolução, liquidação e cancelamento da inscrição ${ }^{159}$.

Questão que surge com o fim da pessoa jurídica é o destino de seu patrimônio, e, na esteira dos ensinamentos de Sílvio RoDRIGUES ${ }^{160}$, podemos dizer, sucintamente, que se

"Art. 51 - Nos casos de dissolução da pessoa jurídica ou cassada a autorização para seu funcionamento, ela subsistirá para os fins de liquidação, até que esta se conclua.

$\S 1^{\circ}$ - Far-se-á, no registro onde a pessoa jurídica estiver inscrita, a averbação de sua dissolução.

$\S 2^{\circ}$ - As disposições para a liquidação das sociedades aplicam-se, no que couber, às demais pessoas jurídicas de direito privado.

$\S 3^{\circ}$ - Encerrada a liquidação, promover-se-á o cancelamento da inscrição da pessoa jurídica”.

157 Sílvio de Salvo VenosA, Direito Civil-Parte Geral, vol. 1, $3^{\text {a }}$ ed., São Paulo, Atlas, 2003, p. 299 :

"Ao contrário do que ocorre com a pessoa natural, o desaparecimento da pessoa jurídica não pode, por necessidade material, dar-se instantaneamente, qualquer que seja sua forma de extinção. Havendo patrimônio e débitos, a pessoa jurídica entrará em fase de liquidação, subsistindo tão-só para a realização do ativo e para o pagamento dos débitos, vindo a terminar completamente quando o patrimônio atingir seu destino".

158 Vide nota 111.

159 Caio Mário da Silva PereIRA, Instituições de Direito Civil - Introdução ao Direito Civil - Teoria Geral de Direito Civil, vol. I, 22 a ed. atualizada por Maria Celina Bodin de Moraes, Rio de Janeiro, Forense, 2007, p. 357:

"A extinção da pessoa jurídica não se pode dar instantaneamente. Qualquer que seja a sua causa (convencional, administrativa, legal, natural), opera-se a terminação da entidade, mas existindo os bens de seu patrimônio, e havendo débitos a resgatar, ela continuará em fase de liquidação, durante a qual subsiste apenas para a realização do ativo e pagamento de dívidas, somente vindo a cessar de todo, ao ser dado ao acervo econômico o destino próprio, como adiante se verá. Até o encerramento desta, por período mais ou menos longo, subsiste a entidade, fazendo-se constar do registro esta circunstância, e devendo configurar-se, em todos os atos, a cláusula em liquidação (art. 51 do Código Civil). Às pessoas jurídicas em geral aplicam-se as normas destinadas à liquidação das sociedades (Código Civil, arts. 1.102 e segs.). Encerrada a liquidação, o liquidante, ou, na sua omissão, qualquer interessado, promoverá o cancelamento do registro".

160 Direito Civil - Parte Geral, vol. 1, 34ª ed., São Paulo, Saraiva, 2007, p. 98: 
tratando de entes com finalidade lucrativa, distribui-se o patrimônio apurado, positivo ou negativo, entre os sócios. Agora, tratando-se de pessoas jurídicas sem fins lucrativos, observar-se-ão, na seguinte ordem, os atos constitutivos e eventual deliberação dos membros. Se ambos forem silentes, o patrimônio destina-se à entidade de finalidade congênere ${ }^{161} \mathrm{e}$, se não houver, à Fazenda Pública. $\mathrm{O}$ mesmo entendimento é acolhido por Orlando GOMES ${ }^{162}$.

A propósito da morte da pessoa jurídica, PONTES DE MIRANDA ${ }^{163}$ alerta para a impropriedade de se falar em "dissolução", visto que a pessoa jurídica não se dissolve, mas deixa de ser pessoa jurídica, perdendo sua capacidade jurídica ou personalidade, porque se dissolveu, aí sim, o suporte fático que dava azo à sua existência como ente abstrato e sujeito de direito. Aponta as seguintes hipóteses: “( $a$ ) o seu suporte fáctico se dissolve, uma vez que ao ato coletivo, que a criou, sucede ato coletivo negativo que a atinge; ou porque $(b)$ à regra jurídica que a permitia sucede incidência de regra jurídica, ou aplicação de regra jurídica, que repila para o mundo fáctico o suporte fáctico; ou porque $(c)$ se retire a autorização estatal, indispensável à personalização; ou porque $(d)$ se chegue ao têrmo ou

\footnotetext{
"Quando se trata de pessoa jurídica com finalidade lucrativa, nenhum problema surge quanto ao destino de seus bens. Eles serão repartidos entre os sócios, pois o lucro constituiu o próprio objeto que os reuniu.

Entretanto, nas associações sem fito lucrativo, seus componentes, por definição mesmo, não visavam a proveitos materiais. Qual o destino do patrimônio da pessoa jurídica que se dissolve?

Em primeiro lugar dever-se-á atentar para o que dizem os estatutos. Se estes forem silentes, deve-se examinar se os sócios adotaram alguma deliberação eficaz sobre a matéria. Se eles nada resolveram, ou se a deliberação for ineficaz, devolver-se-á o patrimônio a um estabelecimento público congênere ou de fins semelhantes (CC, art. 61). Se, porém, no Município ou no Estado, no Distrito Federal ou no Território ainda não constituído em Estado, em que a associação teve sua sede, inexistirem estabelecimentos nas condições indicadas, o patrimônio passará à Fazenda Pública (CC, art. 61, §2º'".

161 Sílvio Rodrigues, Direito Civil - Parte Geral, vol. 1, 34ª ed., São Paulo, Saraiva, 2007, p. 102: "O outro problema se refere à extinção da fundação. Ela se extingue quando vencido o prazo de sua existência. Tal hipótese raramente se apresenta, porque, em geral, a fundação é criada por prazo indeterminado. Além disso, extingue-se quando se torna nociva ao interesse público e, finalmente, quando seu objeto se torna impossível.

Nas três hipóteses, o patrimônio da fundação extinta vai incorporar-se ao de outra de fins idênticos ou semelhantes".

162 Introdução ao Direito Civil, $19^{\mathrm{a}}$ ed. atualizada por Edivaldo Brito e Reginalda Paranhos de Brito, Rio de Janeiro, Forense, 2007, p. 178:

"Dissolvida uma sociedade ou associação, seu patrimônio terá destinação diversa: sendo sociedade, partilha-se entre os sócios, sendo associação, devolve-se à pessoa designada no estatuto e, sendo este omisso, à que for indicada na lei.

As fundações extinguem-se quando se verifica a nocividade do fim ou a impossibilidade de manutenção. Terminam ainda ao se vencer o prazo de sua existência ou se deixa de ser realizável o fim a que se destinam.

Extinta a fundação, o patrimônio incorpora-se ao de entidades congêneres, que tenham fins iguais ou semelhantes".

163 Tratado de Direito Privado - Parte Geral - Tomo I - Introdução. Pessoas Físicas e Jurídicas, $4^{\mathrm{a}}$ ed., São Paulo, RT, 1974, pp. 429 e 430.
} 
condição final; ou porque (e) morreram todos seus membros; ou porque $(f)$ o número dêles baixou do número mínimo fixado em lei”.

Verificada alguma das hipóteses de terminação, a fase seguinte é a liquidação. Esta incide sobre o patrimônio, sobre o que pertence ou pertenceu à pessoa jurídica, dizendo respeito ao seu suporte fático, mas não à sua personalidade ou capacidade jurídica. Não necessariamente deve ocorrer, sendo dispensada em determinadas hipóteses ${ }^{164}$. Ocorrendo, sua finalidade principal é apuração de créditos e débitos, com conseqüente satisfação dos credores e destinação de sobras ${ }^{165}$. Termina com o alcance deste objetivo ${ }^{166}$.

Caio Mário da Silva PEREIRA fala em simetria na vida e morte das pessoas naturais e jurídicas, lembrando que se estas não são acometidas da fatalidade que extermina a vida humana, a morte, da mesma forma que nascem por meio dos atos constitutivos, terminam com a dissolução destes mesmos atos. E dependendo da procedência do ato de dissolução,

164 F. C. POnTES DE MiRAnda, Tratado de Direito Privado - Parte Geral - Tomo I - Introdução. Pessoas Físicas e Jurídicas, $4^{\text {a }}$ ed., São Paulo, RT, 1974, pp. 437 e 438:

“O que se liquida é patrimônio. É isso o que se há de entender por 'liquidação das sociedades', em que a elipse ressalta. Nem sempre se liquida. $\mathrm{O}$ ato constitutivo é que decide, em primeira plana, da sorte do patrimônio. Nem ao tratar-se de pessoas jurídicas, se deve cogitar da liquidação. Só se liquida o que pertence ou pertenceu à pessoa jurídica, portanto algo que é estranho à personalidade mesma e só diz respeito ao suporte fáctico. Se o ato constitutivo dispôs que o patrimônio iria à União, ao Estadomembro, ao Território, ou ao Município, ou a alguma outra pessoa, de direito público ou privado, dá-se a sucessão sem liquidação, ou após liquidação, se foi admitido, o que é de se assentar, na dúvida. Nas espécies em que as pessoas de direito público, ou de direito privado, recebem patrimônio por fôrça de lei, tudo se passa à semelhança da sucessão das pessoas físicas. Também pode deixar de haver liquidação, se foi previsto que se acordasse na destinação do patrimônio e isso se fêz, excluída a liquidação prévia. Se não há sucessão segundo a lei, ou conforme o ato constitutivo, nem por acôrdo dos membros, o patrimônio tem de ser partilhado pelos membros. Ainda aí a partilha amigável pode excluir a liquidação, sem prejuízo a terceiros, ou a terceiro e à minoria (arg. ao art. 21, I)".

165 F. C. PonTES DE MIRANDA, Tratado de Direito Privado - Parte Geral - Tomo I - Introdução. Pessoas Físicas e Jurídicas, $4^{\text {a }}$ ed., São Paulo, RT, 1974, pp. 439-440:

"A liquidação é procedimento para se pagarem as dívidas e se atribuir a quem deva o que sobrar. Durante ela, considera-se como subsistente a pessoa jurídica, para o fim de liquidação. A vida, pròpriamente, terminou; o que continua é o processo de decomposição. (...)

A transferência a favor dos que hão de receber o que fôr apurado opera-se como pagamento. Tem êles crédito contra a massa líquida. (C. CROME, System, I, 258, nota 14; O. WARNEYER, Kommentar, I, 79), desde a perda da personalidade pela entidade dissolvida. Não importa se o destinatário conhece o seu direito, ou se o não conhece, ou, ainda, se não reconhece que é credor; nem se há de exigir qualquer contraprestação. (...)

(...) Se há insolvência, ou falência, o processo é o de concurso de credores ou falencial. Se algo resta de ativo, passa-se do processo concursal ou falencial ao de liquidação (E. JAEGER, Kommentar zur Konkursordnung, 449, nota 12; H. DERnBURG, Das Burgerliche Recht, I, 240)”.

166 F. C. Pontes DE MiRAndA, Tratado de Direito Privado - Parte Geral - Tomo I - Introdução. Pessoas Físicas e Jurídicas, $4^{\mathrm{a}}$ ed., São Paulo, RT, 1974, p. 441:

"A liquidação termina com a entrega da quota ao último dos membros, ou com a adjudicação ao adquirente único, ou cessionário, ou cessionários, ou com a transferência a nova pessoa jurídica. (...)". 
tem-se três diferentes modalidades de extinção: convencional, legal, administrativa, judicial e natural $^{167}$.

A dissolução convencional funda-se na mesma vontade humana criadora que teve o poder de dar vida, personalidade ao ente abstrato, e lha pode tirar, resguardados sempre os interesses da minoria, se emissão da vontade extintiva não unânime e absoluta, e de terceiros, que não interferem no ato de vontade, mas a lei lhes resguarda eventuais direitos que possam ser prejudicados com o fim da pessoa jurídica ${ }^{168}$.

Dissolução legal é aquela modalidade de extinção da pessoa jurídica calcada na própria lei, como, v.g., as sociedades acometidas pela falência ou quando desaparece o seu capital de modo a impossibilitar sua subsistência ${ }^{169}$.

A dissolução administrativa reside naquela seara excepcional de pessoas jurídicas que têm como pressuposto para o seu funcionamento a autorização do Estado. Definindo a

167 Instituições de Direito Civil - Introdução ao Direito Civil - Teoria Geral de Direito Civil, vol. I, $22^{\mathrm{a}}$ ed. atualizada por Maria Celina Bodin de Moraes, Rio de Janeiro, Forense, 2007, p. 353:

"Não subordinadas as pessoas jurídicas à fatalidade de um acontecimento (morte) que conduz as pessoas físicas ao seu fim (De Page), existe, todavia, certa simetria entre a criação e o desaparecimento das sociedades ou associações: causado o seu nascimento por um ato de dissolução, o qual, em razão da natureza e da procedência, pode assumir três formas distintas, a que correspondem três modalidades de extinção: convencional, legal e administrativa".

168 Caio Mário da Silva PereIRA, Instituições de Direito Civil - Introdução ao Direito Civil - Teoria Geral de Direito Civil, vol. I, 22 a ed. atualizada por Maria Celina Bodin de Moraes, Rio de Janeiro, Forense, 2007, pp. 353 e 354 :

"Dissolução convencional é a que deliberam os seus membros componentes e encontra seu fundamento ético no mesmo poder criador que o ordenamento legal atribui à vontade humana. Hábil a gerar um ente distinto dos indivíduos que proferiram a emissão de vontade criadora, é dotada de capacidade de extingui-lo. (...)

A deliberação hábil será tomada pelo quorum previsto nos estatutos ou na lei. Se não for unânime, a minoria tem ressalvados os seus direitos, quer para opor-se à dissolução, se para tal encontrar fundados motivos, quer para defender seus interesses, acaso feridos na eventualidade.

Ficam ressalvados, igualmente, os direitos de terceiros, que, evidentemente, não têm qualidade para se oporem à deliberação, limitado o seu poder à defesa de seus interesses contra qualquer prejuízo resultante da convenção extintiva".

169 Caio Mário da Silva PEREIRA, Instituições de Direito Civil - Introdução ao Direito Civil - Teoria Geral de Direito Civil, vol. I, 22 a ed. atualizada por Maria Celina Bodin de Moraes, Rio de Janeiro, Forense, 2007, p. 354:

"Dar-se-á dissolução legal quando ocorrer em razão de um motivo determinado em lei. Devemos distinguir as sociedades das associações, de vez que a vontade legal atua diversamente, em um e outro caso. As primeiras encontram na lei motivos peculiares de dissolução, quando desaparece o seu capital, ou reduz-se sensivelmente, impossibilitando a sua persistência, pela falência, incapacidade ou morte de um dos sócios; pela renúncia de qualquer deles, se a sociedade for por prazo indeterminado. Já as associações não se extinguem pela redução ou desaparecimento do capital, pois que este não é requisito de sua existência; seu quadro social é normalmente indeterminado, e, por conseguinte, a morte ou incapacidade de qualquer associado não atinge a existência da pessoa jurídica; não há cogitar sua falência". 
Administração Pública pela cassação do seu beneplácito ou pela não renovação de autorização temporária, o ente abstrato deverá sucumbir ao ius imperii do Poder Público ${ }^{170}$.

Dissolução judicial é aquela cujo ato de extinção, sob o aspecto formal, vem sob a forma de decisão do Poder Judiciário, embora a causa material, sempre, encontrará resguardo numa das hipóteses anteriores. Configura-se uma das modalidades de extinção e a pessoa jurídica continua a funcionar; sendo a contenda levada ao Judiciário para solução, o ato de juiz que declarar a terminação do ente abstrato encontrará abrigo nesta modalidade de extinção ${ }^{171}$.

Por fim, fala-se em dissolução natural na hipótese em que morrem todos os membros da pessoa jurídica, não restando nenhum, ou restando apenas um deles na sociedade, ele não reconstitua a pluralidade de sócios dentro do interregno legalmente assinalado $^{172}$.

170 Caio Mário da Silva PereIRA, Instituições de Direito Civil - Introdução ao Direito Civil - Teoria Geral de Direito Civil, vol. I, 22 a ed. atualizada por Maria Celina Bodin de Moraes, Rio de Janeiro, Forense, 2007, p. 355:

"Dissolução administrativa é a que atinge as pessoas jurídicas que necessitam de aprovação ou autorização do poder público para se constituírem ou funcionarem. Se praticam atos opostos aos seus fins, ou nocivos ao bem coletivo, a administração pública, que lhes dera autorização para funcionamento, pode cassá-la, daí resultando a terminação da entidade, uma vez que a sua existência decorrera daquele pressuposto. Não pode, porém, proceder discricionariamente o Poder Executivo, revogando unilateralmente a autorização, sem causa justificativa, e, se o fizer procede contra direito, sujeitando o Estado ao ressarcimento do dano causado. Mas se a autorização é temporária, a recusa do poder público situa-se na órbita de seu poder discricionário, e, em consequiência, a falta de renovação implica a terminação da sociedade, sem direito a indenização. Também ocorrerá cassação da autorização se a entidade proceder conta o direito ou a ordem pública".

171 Caio Mário da Silva PEREIRA, Instituições de Direito Civil - Introdução ao Direito Civil - Teoria Geral de Direito Civil, vol. I, 22a ed. atualizada por Maria Celina Bodin de Moraes, Rio de Janeiro, Forense, 2007, p. 355:

"Pode-se destacar a chamada dissolução judicial, em razão da sua subordinação ao processo contencioso in iudicio, porque decorrente de um ato jurisdicional quando se configura algum dos casos de dissolução prevista em lei ou no estatuto, e, não obstante, a sociedade continua operando, o juiz, por iniciativa de qualquer dos sócios, decreta a sua terminação. Quando for questionada a impossibilidade de sua sobrevivência, e a sentença que dirimir a contenda assim concluir; ou ainda, por ação direita, mediante denúncia de qualquer do povo ou do Ministério Público, em razão de promover atividade ilícita ou imoral, a dissolução assenta na sentença judicial. Em todos esses casos, é judicial a extinção, encarada sob o aspecto formal, porque o ato extintivo é de natureza judicial. Mas do ponto de vista causal, a dissolução vai encontrar classificação na sua razão determinante".

172 Caio Mário da Silva PereIRA, Instituições de Direito Civil-Introdução ao Direito Civil - Teoria Geral de Direito Civil, vol. I, 22a ed. atualizada por Maria Celina Bodin de Moraes, Rio de Janeiro, Forense, 2007, pp. 355 e 356:

"Podemos denominar extinção natural a que provém da morte dos membros da associação. Se os estatutos admitirem que subsista com os sobreviventes em caso de morte de alguns deles, respeita-se a disposição por amor à vontade constitutiva, mas cumpre esclarecer até quando perdurará a pessoa jurídica, no desfalque de seus membros, ou na diminuição do número de associados. (...) O fundamento da permanência da sociedade, com a morte de todos os associados, menos um, consagrada pelo Código Civil, está em que será possível, em torno dele, reconstituir-se a entidade, o que repetimos, é tão ilógico quanto a regra canônica que admite persistência do ente jurídico mesmo que morram todos os 


\section{II - REPRESENTAÇÃO DA PESSOA JURÍDICA}

\subsection{O Negócio Jurídico}

O direito cuida da disciplina dos acontecimentos do mundo real sobre os quais incide norma jurídica, a qual se subsume ao fato natural, tornando-o fato jurídico ${ }^{173}$. Estes fatos jurídicos em sentido largo dividem-se em "fatos jurídicos estricto sensu", que são os acontecimentos naturais, sem intervenção da vontade humana, mas com desdobramentos no âmbito do direito, e nos "atos jurídicos”, estes, as ações humanas com repercussão jurídica $^{174}$.

Os "atos jurídicos", por seu turno, divide-os a melhor doutrina em "negócios jurídicos" e "atos jurídicos estricto sensu" ou "atos não-negociais" "175. Alertando para a necessidade de clara distinção ${ }^{176}$, ORLANDO GOMES qualifica o ato jurídico estricto sensu como sendo o fato jurídico oriundo de ação humana ${ }^{177}$ e tendo como objeto uma manifestação de vontade não compreendida na esfera da autonomia privada do agente, de

associados. A doutrina do Código Civil de 1916, entretanto, sobrevive no Código de 2002 e, dispondo sobre as sociedades, determina prazo de 180 dias para que seja reconstituída a pluralidade de sócios, antes da dissolução (art. 1033, IV)".

173 Antônio Junqueira de AZEVEDo, Negócio Jurídico - Existência, Validade e Eficácia, 4ª ed., São Paulo, Saraiva, 2007, p. 23:

"Fato jurídico é o nome que se dá a todo fato do mundo real sobre o qual incide norma jurídica. Quando acontece, no mundo real, aquilo que estava previsto na norma, esta cai sobre o fato, qualificando-o como jurídico; tem ele, então, existência jurídica. (...)"

174 Orlando Gomes, Transformações Gerais do Direito das Obrigações, São Paulo, RT, 1967, p. 73:

“(...) Considerados fatos jurídicos os acontecimentos naturais ou ações humanas que recebem da lei significação própria, dividem-se, respectivamente, em fatos jurídicos stricto sensu e atos jurídicos. A qualificação dos acontecimentos naturais faz-se correntemente com a expressão fatos jurídicos, desacompanhada dos termos restritivos, raramente se empregando no sentido genérico, que compreende todos os atos jurídicos. Procede-se dêsse modo, por mais cômoda, a simplificação. Demais dessa razão ao se empregá-la, tem-se em vista, mais comumente, figurá-la como categoria que opõe à dos atos jurídicos, com a finalidade de separar inequìvocamente os fatos jurídicos oriundos dos acontecimentos naturais dos que resultam de ações humanas. Englobam-se estas na denominação genérica de atos jurídicos. (...)".

175 Orlando GoMES, Transformações Gerais do Direito das Obrigações, São Paulo, RT, 1967, p. 73:

“(...) Predomina, atualmente, a concepção dualista pela qual a expressão atos jurídicos compreende duas categorias de fatos jurídicos lato sensu, a dos negócios jurídicos e a dos atos jurídicos stricto sensu ou atos não-negociais. Desta corrente doutrinária, não se afastam quantos continuam a denominar atos jurídicos os negócios jurídicos, conceituando-os com os elementos característicos desta subespécie dos atos jurídicos lato sensu. Simplesmente não empregam a expressão negócio jurídico. Entre nós, sòmente nos últimos tempos essa expressão se vai tronando corrente no vocabulário jurídico. (...)".

176 Orlando GoMes, Transformações Gerais do Direito das Obrigações, São Paulo, RT, 1967, p. 74: “(...) O importante é, em suma, reconhecer-se que não se pode designar por denominação única os atos que os dualistas qualificam como negócios jurídicos e atos jurídicos estricto sensu ou não negociais".

177 Orlando Gomes, Transformações Gerais do Direito das Obrigações, São Paulo, RT, 1967, p. 78:

“(...) Para que um fato exterior se classifique como ato jurídico stricto sensu mister se faz que resulte da atividade humana, que, para a sua produção, concorra a vontade do homem. Se ocorre o fato sem essa intervenção, ato jurídico não é, mas, sim, fato jurídico stricto sensu. (...)”. 
modo que não se perfaz em declaração de vontade, ou seja, essa manifestação de vontade não tem o condão de atingir determinado resultado previsto pelo ordenamento jurídico, atinge um resultado que seria atingido de qualquer modo, independente da vontade do emissor ser ou não naquele sentido ${ }^{178}$.

Tal é a proeminência e importância dos negócios jurídicos para o direito privado, que o atual Código Civil brasileiro lhe dedica ampla disciplina ${ }^{179}$, reservando aos "atos jurídicos em sentido estrito" tão-somente um artigo ${ }^{180}$, o qual se limita a dispor sobre a incidência no que couber das regras descritas para o negócio jurídico.

Assim, pode-se, na esteira do pensamento do Professor ANTÔNIO JUNQUEIRA DE AzEVEDo, definir o "negócio jurídico" como sendo o fato jurídico oriundo da ação humana, portanto, categoria de ato jurídico, que consiste em uma manifestação de vontade, que revestida por certas circunstâncias negociais, o direito lhe reconhece o condão de gerar efeitos jurídicos previamente descritos pelo ordenamento ${ }^{181}$. Trata-se a manifestação de vontade aqui versada, de declaração de vontade, entendido o termo em sua acepção

178 Orlando GoMES, Transformações Gerais do Direito das Obrigações, São Paulo, RT, 1967, pp. 78 e 79: "Em síntese, requer o ato jurídico stricto sensu ou não-negocial, por definição, uma atividade humana caracterizada pelo conteúdo psicológico da atuação da vontade, uma ação na qual a lei considera, não sòmente o fato exterior, mas, também, um fato psíquico interior que, tanto pode consistir em uma intenção como numa representação mental, segundo ENNECCERUS, constitui elemento indispensável à caracterização do ato não-negocial. Quando consiste numa vontade, é preciso que sua manifestação, não estando compreendida na esfera da autonomia privada do agente, não se dirija ao efeito jurídico correspondente ao interêsse visado, que não seja, numa palavra, a vontade de resultado, pois que tal vontade é, sob o ponto-de-vista funcional, o traço distintivo do negócio jurídico. Nos atos jurídicos stricto sensu deve haver, por conseguinte, manifestação da vontade sem a significação de declaração de vontade e manifestação de vontade que não encerre vontade de resultado. Simplificando: o ato jurídico stricto sensu que consiste na exteriorização da vontade, mediante certo tipo de conduta, não se realiza pela comunicação do intento do agente a outrem e o efeito jurídico que provoca se produz, estivesse ou não, no propósito de quem o pratica, suscitá-lo. Êle não é, como o negócio jurídico, um ato de autonomia privada".

179 Código Civil - artigos 104 a 188.

180 Código Civil:

"Art. 185 - Aos atos jurídicos lícitos, que não sejam negócios jurídicos, aplicam-se, no que couber, as disposições do Título anterior”.

181 Antônio Junqueira de AZEVEDO, Negócio Jurídico - Existência, Validade e Eficácia, $4^{\mathrm{a}}$ ed., São Paulo, Saraiva, 2007, p. 16:

“Como categoria, ele é a hipótese de fato jurídico (às vezes 'suporte fático'), que consiste em uma manifestação de vontade cercada de certas circunstâncias (as circunstâncias negociais) que fazem com que socialmente essa manifestação seja vista como dirigida à produção de efeitos jurídicos; negócio jurídico, como categoria, é, pois, a hipótese normativa consistente na em declaração de vontade (entendida esta expressão em sentido preciso, e não comum, isto é, entendida como manifestação de vontade, que, pelas suas circunstâncias, é vista socialmente como destinada à produção de efeitos jurídicos). Ser declaração de vontade é sua característica específica primária. Segue-se daí que o direito, acompanhando a visão social, atribui, à declaração, os efeitos que foram manifestados como queridos, isto é, atribui a ela efeitos constitutivos de direito - e esta é sua característica específica secundária". 
técnica, visto que o agente ao exprimir sua vontade tem o escopo de que a sua manifestação dê azo às consequiências que a ordem jurídica prevê para a hipótese ${ }^{182}$.

Quando se tem em mente o "fato jurídico lato sensu", definido como o acontecimento sobre o qual incide norma de direito e que gera efeitos na ordem jurídica, para assim caracterizá-lo, há de se proceder análise em dois planos. No primeiro, da existência, verifica-se se o fato traz consigo suficientes elementos para se dizer que ele realmente existe, tais como: quando ocorreu, em que lugar, como ocorreu, etc. No segundo plano, o da eficácia, será averiguado se sobre o apontado fato realmente incide norma de direito e quais os efeitos que sua ocorrência gerou, gera ou gerará para a ordem jurídica ${ }^{183}$.

Tratando-se do negócio jurídico, em razão da especificidade de sua caracterização exigir manifestação de vontade, com escopo específico de gerar efeitos jurídicos previstos pelo ordenamento - efeitos desejados pelo agente no momento que manifesta a vontade, e revestida de circunstâncias negociais que socialmente evidenciam a idéia de que aquela manifestação quer atingir o efeito legal, aparece mais um plano para seu exame, inserto entre o da existência e o da eficácia, o da validade ${ }^{184}$.

182 Antônio Junqueira de AzEVEdo, Negócio Jurídico - Existência, Validade e Eficácia, 4ª ed., São Paulo, Saraiva, 2007, p. 17:

"Ainda como categoria, o negócio jurídico, em segundo lugar, não é um simples fato, no qual a norma jurídica leva em consideração a existência de vontade (um ato); ele é mais do que isso; ele é uma declaração de vontade, isto é, uma manifestação de vontade cercada de certas circunstâncias, as circunstâncias negociais, que fazem com que ela seja vista socialmente como destinada a produzir efeitos jurídicos. O negócio jurídico não é, por outras palavras, uma simples manifestação de vontade, mas uma manifestação de vontade qualificada, ou uma declaração de vontade. (...)".

183 Antônio Junqueira de AzEVEDo, Negócio Jurídico - Existência, Validade e Eficácia, 4ª ed., São Paulo, Saraiva, 2007, pp. 23 e 24:

“(...) O fato jurídico entra no mundo jurídico para que aí produza efeitos jurídicos. Tem ele, portanto, eficácia jurídica. Por isso mesmo, a maioria dos autores define o fato jurídico como o fato que produz efeitos no campo do direito. 'Fatos jurídicos são os acontecimentos em virtude dos quais relações de direito nascem e se extinguem' [Savigny]. Há até mesmo, quem veja nessa eficácia jurídica dos fatos jurídicos a sua essência [Carnelutti]. Em tese, porém, o exame de qualquer fato jurídico deve ser feito em dois panos: primeiramente, é preciso verificar se se reúnem os elementos de fato para que ele exista (plano da existência); depois, suposta a existência, verificar se ele passa a produzir efeitos (plano da eficácia)".

184 Antônio Junqueira de AzEVEDo, Negócio Jurídico - Existência, Validade e Eficácia, 4ª ed., São Paulo, Saraiva, 2007, p. 24:

"Sendo o negócio jurídico uma espécie de fato jurídico, também o seu exame pode ser feito nesses dois planos. Entretanto, e essa é a grande peculiaridade do negócio jurídico, sendo ele um caso especial de fato jurídico, já que seus efeitos estão na dependência dos efeitos que foram manifestados como queridos, o direito, para realizar essa atribuição, exige que a declaração tenha uma série de requisitos, ou seja, exige que a declaração seja válida. Eis aí, pois, um plano para exame, peculiar ao negócio jurídico - o plano da validade, a se interpor entre o plano da existência e o plano da eficácia”. 
Para sua plena realização, deve o negócio jurídico conter os elementos de existência e observar os requisitos de validade e atender aos fatores de eficácia ${ }^{185}$.

A existência do negócio jurídico é atestada pela presença dos elementos que o compõem sob a ótica do direito. Tais elementos, conforme o grau de abstração que se adote, podem ser classificados em gerais, comuns a todo e qualquer negócio jurídico, categoriais, próprios de cada espécie, em particular, do gênero negócio jurídico e, finalmente, os particulares, com sendo aqueles elementos voluntários, insertos no negócio pelas partes, mas que não são imanentes nem aos negócios jurídicos em geral, nem a nenhuma de suas categorias específicas ${ }^{186}$.

Em razão de ter o negócio jurídico como características específicas a declaração de vontade - manifestação de vontade com intenção de gerar efeitos jurídicos previstos pelo ordenamento - e a anuência do direito no tocante à geração destes efeitos pretendidos, vez que circunstancialmente - circunstâncias negociais - declarados, de forma a serem socialmente reputados queridos pelo agente, impõe-se-lhe o plano da validade, ou seja, a observância de regras jurídicas que lhe impingirão o caráter da regularidade ${ }^{187}$. São os

185 Antônio Junqueira de AZEVEDO, Negócio Jurídico - Existência, Validade e Eficácia, $4^{\mathrm{a}}$ ed., São Paulo, Saraiva, 2007, p. 30:

"Elementos, requisitos e fatores de eficácia são respectivamente os caracteres de que necessita o negócio jurídico para existir, valer e ser eficaz. (...)".

186 Antônio Junqueira de AZEVEDO, Negócio Jurídico - Existência, Validade e Eficácia, $4^{\mathrm{a}}$ ed., São Paulo, Saraiva, 2007, pp. 39 e 40:

"Resumindo este parágrafo, podemos, pois, dizer que elemento do negócio jurídico é tudo aquilo que lhe dá existência no campo do direito. Classificam-se, conforme o grau de abstração, em elementos gerais, isto é, próprios de todo e qualquer negócio; categoriais, isto é, próprios de cada tipo de negócio; particulares, isto é, existentes, sem serem gerais ou categoriais, em determinado negócio. Os elementos gerais subdividem-se em intrínsecos (ou constitutivos), que são a forma, o objeto e as circunstâncias negociais, e extrínsecos, que são o agente, o lugar e o tempo do negócio. Os categoriais subdividem-se em inderrogáveis (ou essenciais) e derrogáveis (ou naturais); os primeiros definem o tipo de negócio e os segundos apenas defluem de sua natureza, sem serem essenciais à sua estrutura. Os elementos particulares, finalmente, são em número ilimitado, podendo, porém, ser estudados três, a condição, o termo e o encargo, que, por serem mais comuns, estão sistematizados".

187 Antônio Junqueira de AZEvEDO, Negócio Jurídico - Existência, Validade e Eficácia, $4^{\mathrm{a}}$ ed., São Paulo, Saraiva, 2007, pp. 41 e 42:

"Entende-se perfeitamente que o ordenamento jurídico, uma vez que autoriza a parte a, ou as partes, a emitir declaração de vontade, à qual serão atribuídos efeitos jurídicos de acordo com o que foi manifestado como querido, procure cercar a formação desse especialíssimo fato jurídico de certas garantias, tanto no interesse das próprias partes, quanto no de terceiros e nos de toda a ordem jurídica. Afinal - e, nesse ponto, as análises das definições 'objetivas', 'preceptivas' ou 'normativistas' do negócio são esclarecedoras -, se a parte ou as partes podem criar direitos, obrigações e outros efeitos jurídicos (relações jurídicas em sentido amplo, ditas erroneamente 'normas jurídicas concretas'), através do negócio jurídico, isto é, formulando declaração de vontade, essa verdadeira fonte jurídica não pode entrar a funcionar, dentro do ordenamento como um todo, sem qualquer regulamentação, sob pena de ser total a anarquia; há de se proibir a declaração contrária às normas superiores, há de se cercar de segurança certas declarações que interessam a todos. Se, sob outro ângulo, se permite à vontade humana fixar, em larga escala, o conteúdo da declaração - e aqui são as definições 'voluntaristas' que muito 
requisitos de validade, em última análise, qualificações, dos elementos de existência, que por determinação do ordenamento jurídico devem ser observados para que o negócio jurídico existente seja, também, válido ${ }^{188}$.

Por fim, tem-se o plano da eficácia, no âmbito do qual se verifica se o negócio jurídico existente e válido está apto a gerar os efeitos jurídicos desejados pela vontade declarada $^{189}$. Por regra, os negócios jurídicos têm eficácia imediata, no entanto, há hipóteses em que dependem de fatores extrínsecos ${ }^{190}$ ao negócio para que tenha início a produção de seus efeitos jurídicos ${ }^{191}$.

revelam -, e se os efeitos são imputados à declaração segundo o seu conteúdo, é evidente que se há de tentar evitar que ocorram declarações decorrentes de vontades débeis, ou não correspondentes à exata consciência da realidade, ou provenientes de violência imposta sobre a pessoa que a emitiu etc. Pois bem, o direito, ao estabelecer as exigências, para que o negócio entre no mundo jurídico com formação inteiramente regular, está determinando os requisitos de sua validade.

A validade é, pois, a qualidade que o negócio jurídico, deve ter ao entrar no mundo jurídico, consistente em estar de acordo com as regras jurídicas ('ser regular'). Validade é, como o sufixo da palavra indica, qualidade de um negócio existente. 'Válido' é adjetivo com que se qualifica o negócio jurídico formado de acordo com as regras jurídicas".

188 Antônio Junqueira de AZEVEDO, Negócio Jurídico - Existência, Validade e Eficácia, 4ª ed., São Paulo, Saraiva, 2007, pp. 42 e 43:

"Por isso mesmo, se o negócio jurídico é declaração de vontade e se os elementos gerais intrínsecos, ou constitutivos, são essa mesma declaração tresdobrada em objeto, forma e circunstâncias negociais, e se os requisitos são qualidades dos elementos, temos que: a declaração de vontade, tomada primeiramente como um todo, deverá ser: a) resultante de um processo volitivo; b) querida com plena consciência da realidade; c) escolhida com liberdade; d) deliberada sem ma fé (se não for assim, o negócio poderá ser nulo, por exemplo, no primeiro caso, por coação absoluta, ou falta de seriedade; anulável por erro ou dolo, no segundo; por coação relativa, no terceiro; e por simulação, no quarto). O objeto deverá ser lícito, possível, determinado ou determinável; e a forma, ou será livre, porque a lei nenhum requisito nela exige, ou deverá ser conforme a prescrição legal. Quanto às circunstâncias negociais, não têm requisitos exclusivamente seus, já que elas são o elemento caracterizador da essência do próprio negócio, são aquele quid que qualifica uma manifestação, transformando-a em declaração.

Quanto aos elementos gerais extrínsecos, temos que: a) o agente deverá ser capaz e, em geral, legitimado para o negócio; b) o tempo, se o ordenamento jurídico impuser que o negócio se faça em um determinado momento, quer essa determinação seja em termos absolutos, quer seja em termos relativos (isto é, por relação a outro ato ou fato), deverá ser o tempo útil; e c) o lugar, se, excepcionalmente, tiver algum requisito, há de ser o lugar apropriado".

$\mathrm{O}$ autor invocado prossegue na análise no tocante aos requisitos dos elementos categoriais e particulares, porém, no âmbito deste trabalho, tem-se por suficiente a análise dos requisitos dos elementos gerais intrínsecos e extrínsecos.

189 Antônio Junqueira de AZEVEDO, Negócio Jurídico - Existência, Validade e Eficácia, 4ª ed., São Paulo, Saraiva, 2007, p. 49:

"O terceiro e último plano em que a mente humana deve projetar o negócio jurídico para examiná-lo é o plano da eficácia. Nesse plano, não se trata, naturalmente, de toda e qualquer possível eficácia, prática do negócio, mas sim, tão-só, da sua eficácia jurídica e, especialmente, da sua eficácia própria ou típica, isto é, da eficácia referente aos efeitos manifestados como queridos. (...)".

190 Antônio Junqueira de AZEVEDO, Negócio Jurídico - Existência, Validade e Eficácia, 4a ed., São Paulo, Saraiva, 2007, p. 55:

"De fato, muitos negócios, para a produção de seus efeitos, necessitam de fatores de eficácia, entendida a palavra fatores como algo extrínseco ao negócio, algo que dele não participa, que não o integra, mas contribui para a obtenção do resultado visado".

191 Antônio Junqueira de AZEVEDO, Negócio Jurídico - Existência, Validade e Eficácia, 4ª ed., São Paulo, Saraiva, 2007, p. 60: 
Percebe-se, então, que o Código Civil, ao tratar do "negócio jurídico", cuidou, preponderantemente, da disciplina da sua validade e dos atinentes requisitos. Merece, porém, destaque, a presença do "princípio da conservação"192, notadamente nos arts. $170^{193}, 172^{194}$ e $184^{195}$, nos quais se percebe no legislador claro desiderato de aproveitar e conservar o máximo que for possível do negócio jurídico, seja no plano da existência, da validade ou da eficácia, demonstrando o senso de utilidade e importância para o comércio jurídico reputados ao negócio jurídico pela lei civil brasileira.

\subsection{O Contrato de Mandato}

Trata-se de espécie típica de contrato que tem sua disciplina legal no próprio Código Civil ${ }^{196}$. Na dicção legal, é negócio jurídico por meio do qual alguém, denominado

"Cumpre, finalmente, para termos um quadro completo da questão da eficácia, não perder de vista que, ao falarmos de fatores de eficácia, estamos nos referindo ao início da produção de efeitos; esses fatores de eficácia são, pois, em suas três espécies, fatores de atribuição de eficácia (eficácia em geral, eficácia diretamente visada e eficácia mais extensa). Naturalmente, poderá ocorrer que, uma vez existindo, valendo e produzindo efeitos, o negócio venha, depois, por causa superveniente, a se tornar ineficaz. Haverá, então, ineficácia superveniente, isto é, resolução do negócio. (...)”.

192 Antônio Junqueira de AZEVEDo, Negócio Jurídico - Existência, Validade e Eficácia, 4ª ed., São Paulo, Saraiva, 2007, pp. 66 e 67:

"Tanto dentro de cada plano quanto nas relações entre um plano e outro há um princípio fundamental que domina toda a matéria da inexistência, invalidade e ineficácia; queremos referir-nos ao princípio da conservação. Por ele, tanto o legislador quanto o intérprete, o primeiro, na criação das normas jurídicas sobre os diversos negócios, e o segundo, na aplicação dessas normas, dêem procurar conservar, em qualquer um dos três planos - existência, validade e eficácia -, o máximo possível do negócio jurídico realizado pelo agente.

$\mathrm{O}$ princípio da conservação consiste, pois, em se procurar salvar tudo que é possível num negócio jurídico concreto, tanto no plano da existência, quanto da validade, quanto da eficácia. Seu fundamento prende-se à própria razão de ser do negócio jurídico; sendo este uma espécie de fato jurídico, de tipo peculiar, isto é, uma declaração de vontade (manifestação de vontade a que o ordenamento jurídico imputa os efeitos manifestados como queridos), é evidente que, para o sistema jurídico, a autonomia da vontade produzindo auto-regramentos de vontade, isto é, a declaração produzindo efeitos, representa algo de juridicamente útil. A utilidade de cada negócio poderá ser econômica ou social, mas a verdade é que, a partir do momento em que o ordenamento jurídico admite a categoria negócio jurídico, sua utilidade passa a ser jurídica, visto vez que somente em cada negócio concreto é que adquire existência a categoria negócio jurídico. Não fosse assim e esta permaneceria sendo sempre algo abstrato e irrealizado. Obviamente, não foi para isso que o ordenamento jurídico a criou. $\mathrm{O}$ princípio da conservação, portanto, é a conseqüência necessária do fato de o ordenamento jurídico, ao admitir a categoria negócio jurídico, estar implicitamente reconhecendo a utilidade de cada negócio jurídico concreto".

193 Código Civil:

“Art. 170 - Se, porém, o negócio jurídico nulo contiver os requisitos de outro, subsistirá este quando o fim a que visavam as partes permitir supor que o teriam querido, se houvessem previsto a nulidade".

194 Código Civil:

"Art. 172 - O negócio anulável pode ser confirmado pelas partes, salvo direito de terceiro".

195 Código Civil:

“Art. 184 - Respeitada a intenção das partes, a invalidade parcial de um negócio jurídico não o prejudicará na parte válida, se esta for separável; a invalidade da obrigação principal implica a das obrigações acessórias, mas a destas não induz a da obrigação principal".

196 Código Civil: artigos 653 a 692. 
mandatário, recebe de outra pessoa, denominada mandante, poderes para, em seu nome, praticar atos ou administrar interesses, sendo a procuração ${ }^{197}$ seu instrumento (art. $653^{198}$ ).

Pode-se dizer, portanto, ser negócio jurídico consensual ${ }^{199},{ }^{200}$, bilateral ${ }^{201},{ }^{202}$, gratuito ou oneroso ${ }^{203},{ }^{204}$, cuja extensão do objeto pode ser geral ou especial ${ }^{205},{ }^{206}$.

197 M. Planiol e G. Ripert, (s/ título original), trad. esp. de Jose M. Cajica Jr., Tratado Elemental de Derecho Civil - Teoría General de los Contratos Especiales, vol. 5, México D.F., Cardenas, 1983, p. 502 , nota 7 :

"La procuración no es la prueba del contrato celebrado entre el mandante y el mandatario; no está destinada a servir de título entre las partes, sino a probar a los terceros el poder de representación recibido por el mandatario. Por consiguiente, erróneamente se pregunta, como frecuentemente se hace, si debe expedirse la procuración por duplicado cuando el mandato es remunerado. En efecto, la procuración nunca queda en poder del mandante, a pesar de ser él el único acreedor cuando el mandato es gratuito".

198 Código Civil:

"Art. 653 - Opera-se o mandato quando alguém recebe de outrem poderes para, em seu nome, praticar atos ou administrar interesses. A procuração é o instrumento do mandato".

199 A. Colin e H. CApitant, (s/ título original), trad. esp. de Revista General de Legislacion y Jurisprudencia, Curso Elemental de Derecho Civil, Tomo Cuarto, Madrid, Reus, 1981, pp. 918 e 919:

"l mandato es un contrato consensual y, por consiguiente, no está sometido a ningún requisito de forma, pudiendo ser conferido lo mismo verbalmente que por escrito, si bien en él la prueba de testigos sólo es admitida en las condiciones del derecho común, es decir, con las restricciones prescritas por los artículos 1.341 y 1.347 (art. 1.985, Cód. civ.).

Sucede con mucha frecuencia, según ya hemos dicho, que el poder entregado al mandatario no lleva más que la firma del mandante y que el mandatario acepta tácitamente llevando a cabo el acto que se le encarga. En este caso, el escrito sólo constituye un principio de prueba; el contrato no queda perfeccionado hasta después de su ejecución.

Cuando el mandato tiene por objeto intervenir en una escritura pública, el poder del mandatario debe, en principio, ser otorgado en la misma forma, es decir, ante notario, ya que, en efecto, requiriéndose por la ley el carácter público del instrumento en interés de los contratantes para llamar su atención sobre el acto que realizan, es lógico exigir que el mandante que quiere realizar algún acto en forma solemne manifieste de la misma manera su intención de llevarlo a cabo por mandatario.

(...)

No es necesario que la voluntad del mandante se tenga que expresar de palabra o por escrito, sino que puede ser expresada tácitamente, es decir, que puede resultar de las circunstancias que rodeen las condiciones en que proceda el mandatario".

200 Código Civil:

"Art. 656 - O mandato pode ser expresso ou tácito, verbal ou escrito".

201 De Plácido e Silva, Tratado de Mandato e Prática de Procurações, $1^{\circ}$ vol., $3^{\mathrm{a}}$ ed., Rio de Janeiro São Paulo, Forense, 1959, p. 37:

"Indubitavelmente em sua primeira manifestação, por parte do mandante, o mandato se apresenta sob a feição de ato unilateral. É o elemento primário do contrato que se vai gerar, criando obrigações recíprocas, para o mandante e para o mandatário, as quais já eram designadas pelos romanos como obligatio mandati direta, quanto às referentes ao mandatário, e obligatio mandati contraria, correspondentes às assumidas pelo mandante.

Mas, a unilateralidade do ato é visivelmente efêmera, pois assim se mantém sòmente enquanto o mandatário, ciente da missão que lhe reservou o mandante, ou do encargo que lhe foi cometido, não manifesta o seu consentimento, aceitando ou recusando o mandato, pelo qual, desde que o aceita, assumirá os ônus do encargo ou dos poderes outorgados e, decorrentemente, das obrigações que lhes são inherentes.

Certamente, quando convocado, não anue ao ato inicial pela manifestação de seu consentimento, não se formará o contrato e, conseqüentemente, não haverá obrigações: - restará apenas um ato praticado por alguém, que não teve o merecimento de realizar a sua finalidade. Não nasceu o contrato. E, por isso, nem viveu para criar relações contratuais ou estabelecer vínculos obrigacionais entre contratantes, mandante e mandatário. 
A origem do termo mandato, segundo leciona AFOnSo DiONísio GAMA, remonta à tradição antiga de dar as mãos como forma de se obrigar, daí manus (mão) e data (dada) ${ }^{207}$.

Dessa forma, dentro mesmo das mais preliminares e precisas noções, que traçam as proporções do ato unilateral, vontade isolada, criadora de um ato que irá servir de fundamento ao contrato, quando aceito pela outra parte, não se permite qualquer confusão ou compreensão do mandato como ato unilateral. $\mathrm{O}$ mandato é contrato. E o contrato já induz a demonstração de duas vontades, uma dando poderes de representação, outra os aceitado, sendo, por isso, sempre um ato bilateral, quer dizer, atos praticados por dois lados, conjugados ao mesmo objeto, para a formação do ajuste ou convenção".

202 Código Civil:

“Art. 659 - A aceitação do mandato pode ser tácita, e resulta do começo de execução".

203 M. Planiol e G. RiPert, (s/ título original), trad. esp. de Jose M. Cajica Jr., Tratado Elemental de Derecho Civil - Teoría General de los Contratos Especiales, vol. 5, México D.F., Cardenas, 1983, p. 499:

"Según las ideas romanas, el mandato era esencialmente gratuito. El Código civil admite, por el contrario, que el mandato puede ser remunerado (art. 1896).

(...)

La jurisprudencia admite que la remuneración puede deberse al mandatario sin que haya habido convención expresa. Es así tratándose d las personas cuya profesión consiste en ocuparse de los negocios ajenos, como los agentes de negocios (Cas., 15 jul. 1896. D. 96. 1. 561, S. 97. 1. 269), y de los procuradores. (...)".

204 Código Civil:

"Art. 658 - O mandato presume-se gratuito quando não houver sido estipulada retribuição, exceto se o seu objeto corresponder ao daqueles que o mandatário trata por ofício ou profissão lucrativa.

Parágrafo único. Se o mandato for oneroso, caberá ao mandatário a retribuição prevista em lei ou no contrato. Sendo estes omissos, será ela determinada pelos usos do lugar, ou, na falta destes, por arbitramento".

205 A. COLIN e H. CAPitant, (s/ título original), trad. esp. de Revista General de Legislacion y Jurisprudencia, Curso Elemental de Derecho Civil, Tomo Cuarto, Madrid, Reus, 1981, pp. 923 e 924:

"El mandato concebido en términos generales se dará, por ejemplo, de la manera siguiente: realizar todos os actos necesarios, todo cuanto parezca útil y necesario y todo cuanto exijan las circunstancias.

Un mandato semejante, por el hecho mismo de su imprecisión, ofrece cierto peligro. Nuestros antiguos autores discutían, por tanto, sobre los límites de esta clase de procuración y sobre la amplitud de los poderes que confiere al mandatario (véase Pothier, Mandat, núms. 144 y 145).

Para poner término a esta dificultad, el artículo 1.988 decide que El mandato concebido en términos generales no lleva consigo más poder que el de realizar los actos de administración. Si se trata - añade el texto - de enajenar o de hipotecar o de cualquier otro acto de disposición, el mandato deberá ser expreso.

$<<$ Un hombre no confía un mandato general - decía el tribuno Tarrible - sino cuando larga ausencia le impide gobernar por sí mismo sus asuntos. En semejante posición, debe darse por cierto que ese hombre no tenía otro ánimo que el de atender a la simple administración de sus negocios. La ley presume que se hubiera tenido intención de enajenar, de gravar con hipotecas o de realizar actos de propiedad, no habría dejado de expresar su voluntad acerca de asuntos de tanta importancia, y esta interpretación de la ley ofrece la doble ventaja de ser la más atinada y de acabar con todas las incertidumbres.>>

En cuanto al mandato expreso, se limita a los actos que en el mismo están enunciados. El mandatario no puede hacer nada que rebase los límites de lo que en el mandato se determina (art. 1.989), de suerte que el poder de transigir no abarca el de comprometer en árbitros (art. 1.989, segunda frase), del mismo modo que el poder de enajenar un inmueble no lleva consigo el de cobrar su importe".

206 Código Civil:

“Art. 660 - O mandato pode ser especial a um ou mais negócios determinadamente, ou geral a todos os do mandante.

Art. 661 - O mandato em termos gerais só confere poderes de administração.

$\S 1^{\circ}$ - Para alienar, hipotecar, transigir, ou praticar outros quaisquer atos que exorbitem da administração ordinária, depende a procuração de poderes especiais e expressos.

$\S 2^{\circ}$ - O poder de transigir não importa o de firmar compromisso".

207 Afonso Dionísio GAMA, Das Procurações - Teoria e Prática, 6 ${ }^{\mathbf{a}}$ ed. atualizada por J. do Amaral Gurgel, São Paulo, Saraiva, p. 17: 
Questão controversa surge na aferição dos elementos do contrato, quando se indaga se é de sua essência a representação de uma pessoa por outra. O mesmo AFONSO DiONísIO GAMA $^{208}$, com estribo nos ensinamentos de Clóvis Bevilaqua, afirma que sim, havendo uma substituição de pessoas e aparecendo uma pessoa como prolongamento da outra. DE PLÁCIDO E SILVA ${ }^{209}$ vê a representação como a alma do contrato e lhe sendo retirada essa sua substância, já se terá enveredado para outro instituto que não o mandato.

"Mandato vem de manus, mão, e data, dada; mandata, mão dada, porque o mandatário apertava a mão
de seu constituinte, em sinal de que lhe prometia desvelar-se no negócio comissionado; era êsse o
símbolo de fidelidade na antiguidade (Trindade, Processos extrajudiciais, nota 1). Dêsse aperto de mão,
ensina Gonçalves Maia, Teoria e Prática das Procuraçâes, n. ${ }^{\circ} 7$, resultavam atos jurídicos e
responsabilidades; assim, o mandatário respondia pelas faltas cometidas no exercício do mandato, do
mesmo modo que o mandante ficava obrigado para com o mandatário; (...)". Afonso Dionísio Gama, Das Procurações - Teoria e Prática, 6a ed. atualizada por J. do Amaral Gurgel, São Paulo, Saraiva, pp. 20 e 21:

"O característico essencial do mandato, o que o distingue de qualquer outro contrato, é a representação. Por êle, o mandatário representa, faz as vêzes do mandante, e em nenhuma outra relação jurídica, oriunda de contrato, se dá essa substituição de pessoas, de modo que uma apareça como um prolongamento, uma projeção da outra (Clóvis Bevilaqua, Direito das Obrigações, §117; Trib. de Just. De São Paulo, ac. de 20 de dezembro de 1895, na Gazeta Jurídica do mesmo Estado, vol. 14, pág. 140). (...)".

209 De Plácido e Silva, Tratado de Mandato e Prática de Procurações, $1^{\text {o }}$ vol., $3^{\text {a }}$ ed., Rio de Janeiro São Paulo, Forense, 1959, pp. 22 e 23:

"O Código Civil brasileiro consagra o mandato como um contrato de representação. Dessa forma, não se reduz à ordem dada para que faça alguma coisa, ma importa na aceitação em cumprir esta mesma ordem.

E neste contrato de representação, onde se firmam o poder de agir, emanado da vontade do mandante, e a obrigação de agir, assumida pelo mandatário, está a essência do próprio mandato, isto é, nêle reside a função do mandato, como contrato nominado, seja escrito ou seja não escrito, isto é, verbal ou deduzido.

Desta maneira, quando, segundo o conceito aceito, se afirma que o mandato encerra um poder de representação, não se pode deixar de lado a significação contratual do instituto: é o poder de representação, aceito ou assumido por uma pessoa, ou seja mandatário, assim qualificado em oposição ao que dá ou manda o poder, ou que outorga, denominado mandante.

A substância dêle, pois, como bem assevera PAULO DE LACERDA, assenta na representação conferida, em virtude da qual o mandatário, como representante do mandante, opera em nome dele ou faz suas vezes.

A representação que, em realidade e profanamente, se calca na substituição de uma pessoa por outra, na verificação da essência fundamental do mandato, indica, por essa forma, a sua mais profunda estrutura e a sua mais característica expressão: o mandante se faz representar pelo mandatário nos atos que êste pratica em seu nome e em virtude dos poderes que lhe foram confiados. A vontade do mandante cria asas e vai presidir o ato pela bôca ou pelo ato do mandatário. O mandante se multiplica e vê, pelo mágico poder de representação, sua pessoa praticar atos, assumir obrigações, defender interêsses próprios, pelas mãos e pelos pensamentos de uma outra pessoa, cuja individualidade desaparece para agir em nome de outra individualidade.

E desde que, no mandato, não se firme o caráter representativo, que o domina, não se outorgando nêle poderes para que o mandatário possa agir em nome do mandante, praticando negócios lícitos de seu interêsse, a seu mando, em seu nome e por sua conta, já o instituto enveredará para outra modalidade, porquanto se lhe retirou o requisito fundamental à existência dêle: - a representação é a sua alma; é quem lhe dá vida". 
Dessa opinião, divergem COLIN E CAPITANT ${ }^{210}$, para quem nada impede que as partes do contrato de mandato ajustem que o mandatário tratará com os terceiros em seu próprio nome, sem dar-lhes conhecimento de sua verdadeira condição. Nesta hipótese, o mandatário se obrigará diretamente, ao passo que, quando atua como representante, o vínculo obrigacional se estabelece diretamente entre os terceiros e o mandante. Lembram que no âmbito civil, realmente, é incomum o mandato sem representação, porém, nas operações de direito comercial, pode ter o terceiro interesse em tratar direto com o mandatário, eximindo-se de se preocupar, por exemplo, com a solvência ou idoneidade do mandante e, além do mais, pode ter o mandatário interesse em não revelar ao terceiro quem é o mandante, ante o risco de em futuras operações restar preterida sua participação $^{211}$.

210 A. Colin e H. Capitant, (s/ título original), trad. esp. de Revista General de Legislacion y Jurisprudencia, Curso Elemental de Derecho Civil, Tomo Cuarto, Madrid, Reus, 1981, pp. 911 a 912:

" $<<$ El mandato o procuración es un acto por el cual una persona confiere a otra poder para hacer algo con destino al mandante y en su nombre.

El contrato sólo se perfecciona por la aceptación del mandatario〉> (art. 1.984).

Esta definición que del mandato nos da el artículo 1.934 corresponde a la manera ordinaria y general de ultimarse en la práctica el contrato de mandato. El mandante da al mandatario un poder escrito llamado procuración, en el cual le ordena que realice en su lugar, y en su nombre, una o varias operaciones jurídicas.

(...)

Al leer el artículo 1.984 pudiera creerse que el mandatario obra siempre como representante, es decir, en nombre del mandante, mas si bien es ésta una característica ordinaria del contrato de que nos ocupa, no es una característica esencial, aunque así haya habido quien lo haya pretendido.

Nada hay que impida a las partes convenir en que el mandatario tratará con los terceros en su proprio nombre y sin darles a conocer su verdadera condición. En caso semejante no cabe duda ninguna de que será él el que se obligará, haciéndose acreedor, al paso que cuando obra como representante las relaciones jurídicas se establecen directamente entre el mandante y los terceros. Pero, trate en una o en otra calidad, eso no modifica en nada el carácter del contrato que se ha establecido entre él y el verdadero interesado; este contrato es siempre un mandato".

211 A. Colin e H. CaPitant, (s/ título original), trad. esp. de Revista General de Legislacion y Jurisprudencia, Curso Elemental de Derecho Civil, Tomo Cuarto, Madrid, Reus, 1981, pp. 912 a 913:

"Verdad es que en materia civil es sumamente raro que el mandatario no haga saber a los terceros la calidad en que obra. Revelándosela, en efecto, evita obligarse personalmente y simplifica el estabelecimiento de la relación de derecho que debe, en definitiva, producirse en cabeza de su mandante. Este, sin, embargo, puede tener interés en que los terceros no sepan que la operación se lleva a cabo por su cuenta, en cuyo caso se dice que hay convenio de prête-nom.

En las operaciones comerciales, a la inversa de lo que sucede habitualmente en materia civil, el mandatario o comisionista se compromete casi siempre personalmente, sin indicar el nombre del comitente (art. 94, Cód. de Com.). Esta manera de proceder es, en efecto, más cómoda para los vendedores, que no tienen que preocuparse de la solvencia de los compradores que residen en otras plazas y a veces en otros países. Por lo común el vendedor no quiere tener que ver con nadie más que con el comisionista, cuja honorabilidad y solvencia le son ya conocidas. Y por último, el mismo comisionista, suele tener interés en no descubrir a su comitente el nombre de sus clientes, pues de esta manera evita que para otras operaciones ulteriores se pueda prescindir de su mediación". 
Entre nós, defende essa posição o Professor Fábio Maria de MATTiA ${ }^{212}$, para quem se configura a representação quando os efeitos jurídicos do ato praticado por uma pessoa recaem, diretamente, sobre outra, havendo, nessa medida, uma projeção da personalidade do representado, ao passo que no contrato de mandato, que se aperfeiçoa com o acordo de vontades do mandante e do mandatário, pode haver representação, mas não necessariamente, visto que o mandatário pode obrar no próprio nome e no interesse do mandatário.

PLANIOL E RIPERT ${ }^{213}$ admitem a possibilidade de haver contrato de mandato desacompanhado do fenômeno da representação, porém reconhecem que a redação da lei

212 Fábio Maria de MAtTiA, Aparência de Representação, São Paulo, Gaetano Dibenedetto, 1999, pp. 4 e 5:

"É necessário distinguir os institutos da representação e do mandato.

Isto porque a doutrina e a jurisprudência, em certos países por influência dos intérpretes franceses, confundem os conceitos de representação e mandato.

Mas, submetendo o estudo das duas figuras jurídicas a um critério seguro verifica-se que tal confusão constitui um verdadeiro erro.

Configurar-se-á a representação quando os efeitos jurídicos do ato que uma pessoa executa por conta de outra recaem diretamente sobre esta última como se ela mesma o tivesse praticado.

O representante é uma projeção da personalidade do representado.

(...)

O fenômeno representativo se constitui com o concurso de três pessoas: o representante, o representado e o terceiro.

Já o contrato de mandato se aperfeiçoa com duas pessoas apenas, o mandante e o mandatário.

Por outro lado, a faculdade de representar existe pelo simples fato de o representado manifestar sua intenção de apropriar-se dos efeitos ativos ou de assumir as obrigações que derivam do negócio que por sua conta, execute o representante.

Enquanto que o contrato de mandato requer o acordo de duas vontades, a do mandante e a do mandatário, é condição essencial para que o fenômeno representativo se realize que o representante, sempre, obre em nome do representado, ao passo que no mandato só se requer que o mandatário obre por conta do mandante.

Portanto, na representação a atuação se efetiva em nome do representado, enquanto que, no contrato de mandato o mandatário obra por cona do mandante".

213 M. Planiol E G. Ripert, (s/ título original), trad. esp. de Jose M. Cajica Jr., Tratado Elemental de Derecho Civil - Teoría General de los Contratos Especiales, vol. 5, México D.F., Cardenas, 1983, p. 497:

“Según el art. 1894, el mandato es el contrato por el cual una persona, llamada 'mandante', da a otra, llamada 'mandatario', facultades para realizar en su nombre uno o varios actos jurídicos. (...)

El documento en que consta este poder llama 'procuración', palabra que el art. 1984 emplea erróneamente como sinónimo de 'mandato'.

Esta definición del mandato por el art. 1984 es muy limitada: para el Código civil la esencia del mandato es la representación jurídica del mandante por el mandatario. Ahora bien, esta representación no es sino un perfeccionamiento aportado por el Derecho romano, en el procedimiento, con ayuda del cual el mandatario realiza su misión: el mandato existía antes y se ejecutaba sin representación de una persona por otra, y esta forma primitiva del contrato no ha desaparecido: existe aún en el Derecho mercantil con el nombre de comisión y en el Derecho civil bajo la forma de la convención de testaferro (prête-nom). Es evidente que el comisionista y el testaferro, aunque no den a conocer a su mandante, son mandatarios. Por tanto, la definición del art. 1984 sólo comprende una variedad: el mandato ostensible o mandato representativo, y para extenderla, convendría decir que el mandante encarga al mandatario la realización, en su lugar y a su nombre, de determinados actos, pudiendo emplearse el procedimiento representativo, para distinguir dos variedades de mandatos, pero no para figurar en una definición genérica del contrato". 
francesa de seu tempo - muito semelhante à do atual Código Civil brasileiro - restou muito limitada, abarcando tão-somente o que chamam de mandato ostensivo ou mandato representativo.

Versa a discussão, fundamentalmente, em classificar o elemento representação como categorial inderrogável (ou essencial) ou derrogável (ou natural) do negócio jurídico mandato, na acepção dos ensinamentos do Professor Antônio Junqueira de AzEVEDo. Se acolhida a primeira corrente, para quem a representação é elemento inderrogável, sua ausência dá azo à inexistência do negócio jurídico. Na esteira da segunda corrente, que vê a representação como elemento categorial derrogável do negócio, defluindo de sua natureza, porém não lhe sendo essencial, sua ausência não retira do mundo jurídico o contrato que dela prescindiu.

Superada a querela instalada no tocante a ser ou não a representação da essência do contrato, DE PLÁCIDO E SILVA ${ }^{214}$ esclarece que no âmbito do negócio jurídico do mandato, a representação - tratando da hipótese de negócio jurídico em que esteja presente a representação, para os que não a reputam elemento categorial essencial do contrato - é voluntária, com a propriedade de fazer com que o representado assuma perante terceiros responsabilidade por obrigações oriundas de negócios celebrados pelo representante. $\mathrm{O}$ mandato, nessa medida, regula as relações internas entre o mandante e o mandatário, sendo a representação a situação externa, calcada nos poderes outorgados e oriundos do mandato, que permite ao representante obrigar o representado, afetar-lhe o patrimônio jurídico, restando-lhe atribuídos direta e imediatamente os direitos adquiridos e os deveres

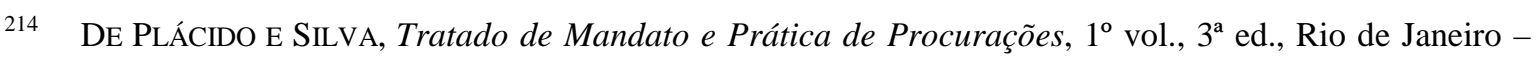
São Paulo, Forense, 1959, pp. 25 e 26:

"A representação que se patenteia como o ato pelo qual alguém aparece praticando atos por outrem, tanto se funda na vontade (contrato), na lei ou em ato emanado da autoridade judicial.

(...)

Se a representação, como no caso do mandato, nasce do contrato, é então voluntária. Tem também a propriedade de fazer o representante agir em nome do representado que, perante terceiros, assume a responsabilidade de tôdas as obrigações derivadas dos atos praticados pelo seu representante, desde que êste, consoante o contrato de representação, agiu com a autoridade conferida, isto é, executou os atos ou negócios nos limites dos poderes concedidos.

A doutrina alemã, segundo nos ensina VITOR LOEWENWATER, emérito prof. de Direito Alemão, na Universidade chilena, se deve o reconhecimento de que o mandato é relação interna entre o mandante e seu mandatário, quer dizer, o contrato que institui os diversos deveres do mandatário, para o qual o mandante necessita plena capacidade de obrigar-se. A representação significa uma situação externa pelos poderes atribuídos ao representante, que lhe dão faculdades para negociar com terceiros, que podem fiar-se nestes poderes aparentes, constantes do instrumento que lhe foi outorgado. $O$ representante opera só por conta do representado e em nome dêste (o comissário, por exemplo, o banqueiro encarregado da compra de ações, age em seu próprio nome). Daí, que tanto os direitos adquiridos como os deveres implicados, ficam constituídos imediatamente na pessoa do representado ou obrigado para com êle". 
assumidos pelo seu representante. Um dos argumentos invocados em favor desta tese é a regra, no direito brasileiro, insculpida de forma mitigada, limitando-se ao relativamente capaz, no art. $666^{215}$ do Código Civil, que dispensa ao mandatário a ostentação de plena capacidade jurídica, exigindo-lha, tão-somente, do mandante ${ }^{216}$ e do terceiro, entre quem se realizará o negócio jurídico ${ }^{217},{ }^{218}$.

Finalmente, no tocante aos efeitos da execução do contrato de mandato - com representação -, a doutrina os divide em dois grupos, sendo o primeiro relativo às situações em que o mandatário leva a cabo a avença nos exatos limites dos poderes que lhe foram outorgados e o segundo, concernente àquelas hipóteses em que o mandatário excede em suas faculdades, indo além dos poderes que lhe foram confiados. No primeiro caso, o mandante resta obrigado diretamente no negócio jurídico celebrado pelo mandatário com o terceiro. No segundo caso, abrem-se duas possibilidades: pode o mandante ratificar os negócios praticados sem poderes por parte do mandatário, obrigando-se, dessa forma, de per si, por sua própria vontade, com os terceiros da relação ou pode o mandante não ratificar os negócios jurídicos celebrados além dos poderes de representação conferidos,

215 Código Civil:

“Art. 666 - O maior de dezesseis e menor de dezoito anos não emancipado pode ser mandatário, mas o mandante não tem ação contra ele senão de conformidade com as regras gerais, aplicáveis às obrigações contraídas por menores".

216 Código Civil:

“Art. 654. Todas as pessoas capazes são aptas para dar procuração mediante instrumento particular, que valerá desde que tenha a assinatura do outorgante.

$\S 1^{\circ}$ - O instrumento particular deve conter a indicação do lugar onde foi passado, a qualificação do outorgante e do outorgado, a data e o objetivo da outorga com a designação e a extensão dos poderes conferidos.

$\S 2^{\circ}$ - O terceiro com quem o mandatário tratar poderá exigir que a procuração traga a firma reconhecida".

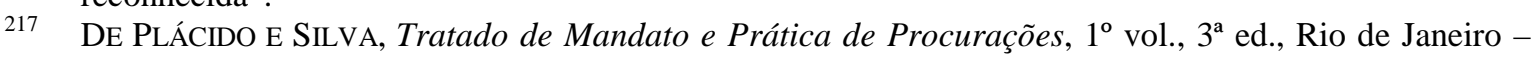
São Paulo, Forense, 1959, p. 26:

"Decorre, daí, o princípio, de que, por não contratar nem assumir obrigações para si, o representante não carece da capacidade exigida ao ato, que pratica para o representado. O representado pode constituir um incapaz, mesmo um menino, para seu representante. A responsabilidade é sua. Os enganos serão também seus".

218 M. Planiol E G. RIPERT, (s/ título original), trad. esp. de Jose M. Cajica Jr., Tratado Elemental de Derecho Civil - Teoría General de los Contratos Especiales, vol. 5, México D.F., Cardenas, 1983, pp. 500 e 501:

"Capacidad del mandante - Quien da un mandato manifiesta su voluntad de realizar el acto que encarga el mandatario; por tanto, debe tener la capacidad necesaria para celebrar el acto, de manera, que no hay una capacidad particular para dar mandato; esta capacidad depende de la naturaleza del acto que se trata de realizar.

Sin embargo, el mandante debe tener, por o menos, la capacidad necesaria para obligarse, cuando el mandato implica una remuneración para el mandatario.

Capacidad del mandatario - La capacidad del mandatario es indiferente para la ejecución del mandato. En consecuencia, puede designarse como mandatario a un incapaz; a una mujer casada no autorizada, a un menor no emancipado, si se tiene confianza en su honradez y en su inteligencia. Débese, lo anterior a que el mandatario no se obliga por los actos que realiza en nombre de su mandante". 
restando-os, assim, inexistentes, por lhes faltar elemento geral intrínseco, a declaração de vontade de uma das partes da relação. Nesta última hipótese, o mandatário não se obriga, a menos que tenha agido em nome próprio e dependendo das circunstâncias pode ser responsabilizado pelos seus atos exorbitantes ${ }^{219}$.

O Código Civil brasileiro disciplina os efeitos da execução do mandato no seu art. $662^{220}$, inquinando com a inexistência o negócio jurídico realizado pelo mandatário sem poderes e com a ineficácia ${ }^{221}$ os celebrados além dos poderes outorgados, mas facultando ao mandante, em qualquer hipótese, ratificar o negócio 222.

219 M. Planiol e G. Ripert, (s/ título original), trad. esp. de Jose M. Cajica Jr., Tratado Elemental de Derecho Civil - Teoría General de los Contratos Especiales, vol. 5, México D.F., Cardenas, 1983, pp. 505 e 506:

" $1^{\circ}$ Casos en que el mandatario no se ha excedido en sus facultades

Obligación del mandante para con los terceros - La ejecución del mandato obliga al mandante directamente para con los terceros, como si hubiese tratado él mismo, sin el empleo de intermediario alguno. Esto es efecto de la representación en los actos jurídicos. (...)

$2^{\circ}$ Casos en que el mandatario se ha excedido en sus facultades

Falta de representación - Cuando el mandatario se excede en las facultades que se han conferido, en realidad obra sin mandato y, por consiguiente, el mandante no esta obligado por lo que su mandatario haya realizado más allá del mandato que le confirió; no ha sido representado (art. 1998, Inc. 2) (...).

Efecto de la ratificación - Todo lo que el mandatario haya hecho excediéndose de los términos de su procuración, puede ser ratificado por el mandante, y entonces su voluntad lo obliga a sí mismo para con los terceros como si hubiese habido mandato previo: Ratihabitio mandato aequiparatur.

Esta ratificación puede ser expresa o tácita (art. 1998, Inc. 2). Los hechos que equivalen a confirmación tácita son apreciados por los tribunales (Cas., 6 feb. 1893, D. 93.1.352).

Responsabilidad del mandatario - Las personas que tratan con el mandatario habrán hecho finalmente un contrato inútil, si el acto no estuviese comprendido en la procuración y si el mandante se niega a ratificarlo. ¿Pueden, en este caso, demandar al mandatario y hacerlo responsable del prejuicio que sufren? Esto depende: si el mandatario les ha dado a conocer suficientemente sus facultades, han tratado con él a su costa e riesgo, y no ha habido sorpresa para ellos. Por el contrario, si no les ha dado a conocer suficientemente sus facultades, el mandatario es culpable y responde personalmente de todo lo que haya podido hacer sobrepasándolos (art. 1997).

Es evidente que si el mandatario, obrando fuera de su procuración, se ha constituido en garante de la ejecución del contrato, está obligado con los terceros para el caso de que el mandante se niegue a rectificar el acto (art. 1997). (...)".

220 Código Civil:

“Art. 662 - Os atos praticados por quem não tenha mandato, ou o tenha sem poderes suficientes, são ineficazes em relação àquele em cujo nome foram praticados, salvo se este os ratificar.

Parágrafo único. A ratificação há de ser expressa, ou resultar de ato inequívoco, e retroagirá à data do ato".

221 Nelson Nery Junior e Rosa Maria de Andrade Nery, Código Civil Comentado, 4a ed., São Paulo, RT, 2006, p. 523:

“(...) Atos praticados por quem não tenha mandato são atinentes à própria existência do mandato e não à sua eficácia. Mas a solução da lei é igual para ambas as hipóteses: ineficácia do ato para o representado. (...) O caput do artigo em questão trata de duas hipóteses: a) que se diz representante por mandato [e] não tem autorização representativa; b) ou tem poderes, mas age fora dos poderes que lhe foram concedidos (ultra fines). A conseqüência, nos dois casos, é a ineficácia do ato para o representado. (...)".

222 Nelson Nery Junior e Rosa Maria de Andrade Nery, Código Civil Comentado, $4^{\mathrm{a}}$ ed., São Paulo, RT, 2006, p. 523:

“(...) Quando não haja poderes de representação, ou eles sejam insuficientes, eventual poder do representante não decorre da procuração, mas da ratificação (no caso do CC 662 par. ún.), ou da 
O dispositivo seguinte, art. $663^{223}$, trata da regra geral, ou seja, agindo o mandatário dentro dos poderes que lhe foram outorgados, restará o mandante, diretamente, obrigado nos negócios jurídicos celebrados com terceiros. Porém, diz também que agindo em seu próprio nome, mesmo que por conta do mandante, o mandatário restará pessoalmente obrigado, o que conduz à idéia de que o ordenamento jurídico brasileiro concebe a possibilidade do mandato sem representação, aliando-se aos que a reputam elemento categorial natural ou derrogável do negócio jurídico mandato, mas contradizendo-se à sua própria definição de mandato, o que ainda sob a égide do velho Código Civil inspirou açodada crítica por parte de Orlando GOMEs ${ }^{224}$.

E encerrando a disciplina do mandato sob o aspecto de sua execução, o art. $665^{225}$ dispõe que no interregno que separa a prática do negócio jurídico pelo mandatário que traiu ou exorbitou poderes e a sua eventual ratificação pelo mandante - se ocorrer -, será aquele mandatário considerado mero gestor de negócios ${ }^{226}, 227$.

legitimação representativa voluntária subseqüente (procuração conferida ex post facto). A ratificação expressa é a aprovação pelo declarada do ato pelo representado. Tácita, é a ratificação (aprovação) que decorre, indiretamente, do comportamento do representado. A legitimação voluntária subseqüente é a outorga de procuração depois de realizado o ato, quando tal providência seja possível".

223 Código Civil:

“Art. 663 - Sempre que o mandatário estipular negócios expressamente em nome do mandante, será este o único responsável; ficará, porém, o mandatário pessoalmente obrigado, se agir no seu próprio nome, ainda que o negócio seja de conta do mandante".

224 Orlando GoMes, Introdução ao Direito Civil, $19^{\mathrm{a}}$ ed. atualizada por Edivaldo Brito e Reginalda Paranhos de Brito, Rio de Janeiro, Forense, 2007, p. 403:

"Verdade é que o Código, contraditoriamente, (RA) editava (RA) regra (art. 1.307) que admitia a atuação do mandatário, sem representação. Preceituava, de fato, que, se o mandatário obrar em seu próprio nome, não teria o mandante ação contra os que com ele contrataram, nem estes contra o mandante. Nessa hipótese, não agia em nome do mandante, deixando de configurar-se, logicamente, em face da definição legal, a relação de mandato, que, entretanto, era admitida.

A antinomia resulta fundamentalmente da falta de preceitos sistemáticos sobre a representação, nos quais se positivasse claramente seu fundamento da procuração ou em outro instrumento pelo qual se outorguem poderes a alguém para suscitar efeitos jurídicos no patrimônio de quem os conferiu mediante declaração própria de vontade. O mandato se configuraria corretamente como o contrato pelo qual uma das partes se obriga a praticar atos jurídicos por conta de outra, quer em nome desta, quer em seu próprio nome.

Dever-se-ia eliminar a contradição entre os artigos 1.288 e 1.307 do Código Civil (RA) de 1916 (RA) [653 e 663 no novo Código Civil], admitindo-se que a representação não é essencial ao mandato e que outros contratos reclamam-na. Cumpria discipliná-la autonomamente, em capítulo especial, mas em termos que permitam oferecer solução às inúmeras questões que suscita, acompanhando os Códigos mais recentes que se inspiraram no $B G B$ ".

225 Código Civil:

"Art. 665 - O mandatário que exceder os poderes do mandato, ou proceder contra eles, será considerado mero gestor de negócios, enquanto o mandante lhe não ratificar os atos".

226 M. Planiol e G. Ripert, (s/ título original), trad. esp. de Jose M. Cajica Jr., Tratado Elemental de Derecho Civil - Teoría General de los Contratos Especiales, vol. 5, México D.F., Cardenas, 1983, p. 513:

"Hay 'gestión de negocios' siempre que una persona realice un acto jurídico en interés de otra, sin haber sido encargado de él. La gestión de negocios difiere, pues, del mandato en que se realiza 
Os artigos 673 e 679 tratam respectivamente das obrigações do mandatário e do mandante. $\mathrm{O}$ art. $673^{228}$ isenta de responsabilidade o primeiro quando age com exorbitância de poderes, mas dá a conhecer aos terceiros com quem trata essa situação, salvo se lhes prometer a futura ratificação dos negócios pelo mandante, ao passo que o art. $679^{229}$ impõe ao mandante a obrigação celebrada pelo seu mandatário que não observa suas instruções, assegurando-lhe tão-somente ação de perdas e danos em face do procurador refratário.

espontáneamente por quién se encarga de ella, en tanto que el mandato es una gestión de negocios emprendida en virtud de una convención, o de la ley. (...)".

227 A. Colin e H. CAPITANT, (s/ título original), trad. esp. de Revista General de Legislacion y Jurisprudencia, Curso Elemental de Derecho Civil, Tomo Cuarto, Madrid, Reus, 1981, pp. 942 a 944:

"Obligaciones del gestor de negocios

Al gestor de negocios le alcanzan las mismas obligaciones que al mandatario. El parágrafo segundo del artículo 1.372 dice que está sometido a todas las obligaciones que resultarían de un mandato expreso que por el propietario se le hubiera conferido.

(...)

En un respecto trata la ley al gestor con más rigor que al mandatario, y es que mientras este último puede renunciar al mandato (art. 2.007), el primero viene obligado a continuar la gestión comenzada y llevarla a término hasta tanto que el propietario se encuentre en situación de atender por si mismo a ella, debiendo encargase igualmente de todas las derivaciones y accesorios del negocio de que se trate (art. 1.372 , pár. $1^{\circ}$ ).

Además, en el caso de que el dueño llegar a fallecer antes que el negocio quede definitivamente ultimado, el gestor viene obligado a continuar su gestión hasta que el heredero pueda hacerse cargo de la dirección del mismo (Cf. artículos 1.373 y 1.991, párrafo $2^{\circ}$ ).

Obligaciones del dueño

Al dueño le alcanzan, en principio, las mismas obligaciones que al mandante.

Hay, sin embargo, entre ambas situaciones importantes diferencias:

$1^{\mathrm{a}}$ El dueño no está obligado - sea para con los terceros, sea para con el gestor del negocio - sino en la medida en que el negocio ha sido bien administrado (art. 1.375) (...) de suerte que el dueño sólo queda obligado por los actos del gestor en tanto que estos actos hayan sido útiles.

Esta disposición es de suma importancia, pues constituye la garantía del dueño contra intervenciones inoportunas de un tercero en sus negocios, y el tribunal será el encargado de apreciar si la operación consumada ofrece o no una utilidad real.

Como bien se concibe, nada semejante existe en materia de mandato, desde el momento que ha habido acuerdo de voluntades sobre el objeto mismo de los actos ha realizar.

Por lo demás, cuando el gestor ha tratado con los terceros en nombre del dueño del negocio y las operaciones por él llevadas a cabo representan una utilidad real para este último, los efectos de estas operaciones se producen directamente en cabeza del dueño, exactamente igual que en materia de mandato, y es, por lo tanto, el dueño mismo quien queda convertido en verdadero acreedor o deudor (...).

Además, cuando el dueño ratifica la gestión llevada a cabo por su cuente, la operación se transforma en un mandato, y son entonces las reglas del mandato las que se aplican: No hay, pues, que tener ya en cuente, en tal caso, las diferencias que arriba señalábamos entre éste y la gestión de negocios.

$2^{\mathrm{a}}$ El dueño no está obligado a reembolsar al gestor más que los gastos útiles o necesarios por él realizados (artículo 1.375, in fine). Damos por supuesto que las operaciones realizadas por el gestor han sido útiles; pero puede suceder muy bien que el gestor haya invertido sumas excesivas, cuya totalidad no vendrá obligado el dueño a reembolsarle, mientras que el mandante, por el contrario, sí vendría obligado a ello (art. 1.999, párr.. 2º)".

228 Código Civil:

"Art. 673 - O terceiro que, depois de conhecer os poderes do mandatário, com ele celebrar negócio jurídico exorbitante do mandato, não tem ação contra o mandatário, salvo se este lhe prometeu ratificação do mandante ou se responsabilizou pessoalmente".

229 Código Civil:

"Art. 679 - Ainda que o mandatário contrarie as instruções do mandante, se não exceder os limites do mandato, ficará o mandante obrigado para com aqueles com quem o seu procurador contratou; mas terá contra este ação pelas perdas e danos resultantes da inobservância das instruções". 
E no tocante à extinção do contrato de mandato, o art. $686^{230}$ assegura aos terceiros de boa-fé a inoposição da revogação dos poderes, caso tenha sido notificado tão-somente o mandatário. Prevalecem os negócios jurídicos, obrigando-se o mandante com os terceiros de boa-fé, mas lhe sendo resguardado acionar o mandatário que agiu sem poderes. Assegura a lei, ainda sob esse aspecto, ser irrevogável o mandato que contenha poderes de cumprimento ou confirmação de negócios encetados, aos quais se ache vinculado.

No âmbito do presente estudo, basta restar claro que o contrato de mandato é fonte de representação jurídica, sem necessidade de adesão a nenhuma das correntes doutrinárias em choque sob esse aspecto específico, podendo, nesse diapasão, ser celebrado entre uma pessoa jurídica e outra pessoa, física ou jurídica, para que esta a represente, com poderes para atingir seu patrimônio jurídico, obrigando-a, inclusive $\mathrm{e}^{231}$.

Trata-se, portanto, o contrato de mandato, de hipótese de representação da pessoa jurídica por outra pessoa, se tiver como objeto a celebração de negócios jurídicos em nome do ente abstrato, obrigando-o e aproveitando-o. Percebe-se, desde já, nos dispositivos analisados, forte convicção do Código Civil em proteger os terceiros de boa-fé que, por ausência ou excesso de poderes do mandatário, possam ver frustrados ou prejudicados os negócios jurídicos que empreenderam.

230 Código Civil:

"Art. 686. A revogação do mandato, notificada somente ao mandatário, não se pode opor aos terceiros que, ignorando-a, de boa-fé com ele trataram; mas ficam salvas ao constituinte as ações que no caso lhe possam caber contra o procurador.

Parágrafo único. É irrevogável o mandato que contenha poderes de cumprimento ou confirmação de negócios encetados, aos quais se ache vinculado".

231 De Plácido e Silva, Tratado de Mandato e Prática de Procurações, $1^{\circ}$ vol., $3^{a}$ ed., Rio de Janeiro São Paulo, Forense, 1959, p. 12, nota 1:

“ - (...) pessoa é entidade física, pessoa natural, na técnica jurídica, para distinguí-la da pessoa jurídica, entidade criada por uma ficção legal, para indicar as associações, sociedades, ou quaisquer outras organizações coletivas, a que a lei dá personalidade jurídica, de que resulta sua aptidão para adquirir direitos e contrair obrigações.

- Não obsta, porém, que essas pessoas jurídicas, colocadas semelhantemente, no exercício de direitos, às pessoas físicas ou naturais, também se possam fazer representar ou substituir por outras pessoas físicas ou mesmo jurídicas, a fim de que pratiquem pelo mandato, atos em seu nome.

E o fenômeno ocorre na mesma proporção, e com a mesma eficácia, que no caso da representação da pessoa natural". 


\subsection{A Representação}

O negócio jurídico tem como pressuposto fático a declaração de vontade e, portanto, e por regra, requer participação direta e pessoal do agente ${ }^{232}$.

Ocorre, porém, que a evolução do comércio jurídico passou a demandar maior agilidade na prática negocial, de modo a permitir ao agente a celebração de negócios jurídicos por meio de outra pessoa, que por ele declara vontade e em seu nome ou no seu interesse aperfeiçoa os negócios jurídicos, ampliando, por assim dizer, sua esfera de atuação ${ }^{233}$.

Admite, então, o direito, o fenômeno da representação, pelo qual uma pessoa chamada representante declara vontade de modo a aperfeiçoar um negócio jurídico, porém, quem tem o patrimônio jurídico atingido, obrigando-se ou adquirindo direitos, é o representado. A gênese do instituto repousa no chamado poder de representação, que permite ao representante declarar vontade de modo a afetar não o seu patrimônio jurídico, mas o do representado ${ }^{234}$.

Além do poder de representação integram, ainda, a etiologia do fenômeno da representação a contemplatio domini, performada no animus do representante em obrar pelo representado, obrigando-o ou lhe contraindo direitos, a substituição da declaração de

232 Caio Mário da Silva PereIRA, Instituições de Direito Civil - Introdução ao Direito Civil - Teoria Geral do Direito Civil, 22a ed. atualizada por Maria Celina Bodin de Moraes, Rio de Janeiro, Forense, 2007, p. 613:

"O ato negocial, assentado no pressuposto fático da declaração de vontade, exige que o agente faça emissão volitiva, o que sugere, de pronto, a sua participação direta e pessoal. (...)".

233 Sílvio de Salvo Venosa, Direito Civil-Parte Geral, $3^{\text {a }}$ ed., São Paulo, Atlas, 2003, p. 391:

"Geralmente, é o próprio interessado, com sua vontade, que atua em negócio jurídico. Dentro da autonomia privada, o interessado contrai pessoalmente obrigações e, assim, pratica seus atos da vida civil em geral. Contudo, em uma economia evoluída, há a possibilidade, e muitas vezes se obriga, de outro praticar atos da vida civil no lugar do interessado, de forma que o primeiro, o representante, possa conseguir efeitos jurídicos para o segundo, o representado, do mesmo modo que este poderia fazê-lo pessoalmente.

O representado, ao permitir que o representante aja em seu lugar, amplia sua esfera de atuação e a possibilidade de defender seus interesses no mundo jurídico. O representante posiciona-se de maneira que conclua negócios em lugar diverso de onde se encontra o representado, ou quando este se encontra temporariamente impedido de atuar na vida negocial, ou ainda quando o representado não queira envolver-se diretamente na vida dos negócios".

234 Caio Mário da Silva PereIRA, Instituições de Direito Civil - Introdução ao Direito Civil - Teoria Geral do Direito Civil, 22a ed. atualizada por Maria Celina Bodin de Moraes, Rio de Janeiro, Forense, 2007, p. 616:

"Na representação, é presente uma idéia essencial: desde que o representante procede, atua, emite vontade em nome do representado, que é quem se torna obrigado ou adquire direitos, necessita, para assim proceder, e, com tais conseqüências, de estar investido de um poder. É o poder de representação, pois, a alma do instituto, e é nele que repousa a sua fundamental valia e a explicação do desdobramento dos efeitos do negócio jurídico da pessoa de quem o pratica, e sua percussão na esfera jurídica de quem nele não é parte direta". 
vontade do representado pela do representante, sendo que este declara sua vontade em nome daquele, e se limitar essa declaração de vontade aos parâmetros fixados no poder de representação concedido pela lei ou pela convenção ${ }^{235}$.

Devem ser distinguidos os papéis exercidos pelos núncios ou mensageiros, que portam a declaração de vontade do agente que celebra o negócio jurídico, porém, sem dele participarem. São simples mediadores, que não suprem a vontade do agente, mas somente transportam-na. Nessa hipótese, por óbvio, não se há de pensar em representação ${ }^{236}$.

Caio Mário da Silva PEREIRA leciona que a representação tem como causa remota sempre a lei, visto que é somente com autorização do ordenamento jurídico que se pode conceber o fenômeno pelo qual o representante procede nomine alieno, de forma a gerar efeitos jurídicos para o representado ${ }^{237}$. Pode, porém, receber classificação de acordo com sua causa próxima, sendo a representação legal ou de ofício aquela que deriva diretamente de comando legal, para Orlando GOMES ${ }^{238}$, em razão de relevante interesse jurídico. Já a

235 Caio Mário da Silva PereIRA, Instituições de Direito Civil - Introdução ao Direito Civil - Teoria Geral do Direito Civil, 22a ed. atualizada por Maria Celina Bodin de Moraes, Rio de Janeiro, Forense, 2007, p. 620:

"Além do poder de representação, examinado supra, costumam os autores descrever que integram a etiologia da representação: a) a contemplatio domini, isto é, o animus do representante que, por agir em nome do representado, procede com a intenção de adquirir direitos e contrair obrigações para este e não para si mesmo; b) a manifestação da própria vontade do representante, em substituição à do representado; c) conter-se a declaração de vontade do representante emitida em lugar do representado, dentro do poder de representação, recebido da lei ou da convenção. (...)".

236 Caio Mário da Silva PEREIRA, Instituições de Direito Civil - Introdução ao Direito Civil - Teoria Geral do Direito Civil, 22a ed. atualizada por Maria Celina Bodin de Moraes, Rio de Janeiro, Forense, 2007, p. 615:

"Daí, já se pode numa ressalva indispensável, excluir da representação a figura do mensageiro ou núncio, que não emite uma declaração de vontade própria, porém, se limita a ser o portador da manifestação volitiva de outrem, que transmite como recebe, e não comparece no negócio jurídico, mas é mero porta-voz do interessado. É bem de ver, portanto, que neste caso, do mensageiro, nem há representação, nem pode ocorrer suprimento da vontade do agente, sendo incompatível a figura do núncio com a realização do negócio jurídico, quando o agente é inapto a fazer, ele mesmo, uma emissão volitiva pessoal e imediata. Mas, pelo fato de não ser o mensageiro participante do negócio jurídico, porém simples medianeiro ou portador da declaração de vontade do agente (em transmissão oral, ou por carta, ou por outra forma de comunicação), não há cogitar sua capacidade. Na verdade, desde que não interpõe sua vontade, pode o núncio ser um incapaz. Basta que possa transmitir a declaração volitiva alheia. Mas não quer isto dizer que o papel do mensageiro seja indiferente ao desenvolvimento do negócio. Ao contrário, se transmite com fidelidade a declaração, dará causa à anulação do negócio (...), respondendo, ainda, por perdas e danos se o fizer em procedimento contrário ao direito".

237 Caio Mário da Silva PereIRA, Instituições de Direito Civil - Introdução ao Direito Civil - Teoria Geral do Direito Civil, 22a ed. atualizada por Maria Celina Bodin de Moraes, Rio de Janeiro, Forense, 2007, pp. 616 e 617:

"Este poder, em última análise, vem da lei, pois somente o tem o representante para proceder nomine alieno, naqueles ordenamentos jurídicos em que é admitida, e nos limites em que é tolerada tal situação. Mas, tendo em vista a sua causa próxima, diz-se que a representação pode ser legal ou convencional'.

238 Orlando GOMES, Introdução ao Direito Civil, $19^{\mathrm{a}} \mathrm{ed}$. atualizadapor Edivaldo Brito e Reginalda Paranhos de Brito, Rio de Janeiro, Forense, 2007, pp. 389 e 390: 
representação voluntária ou convencional, é aquela calcada na autonomia da vontade do agente, que, com substrato em um negócio jurídico subjacente, o qual pode ser o de mandato $^{239}$, emite nova declaração de vontade, concedendo poderes ao representante e de modo a performar a representação.

Outra classificação distingue a representação em direta e indireta, diferenciando uma da outra por haver na modalidade direta sujeição do patrimônio jurídico do representado ao negócio levado a cabo pelo representante, e, na indireta, o representante agir no próprio nome, mas tão-somente no interesse do representado ${ }^{240}$.

\footnotetext{
“A representação legal é instituída em razão de relevante interesse jurídico. Diante a impossibilidade jurídica das pessoas incapazes proverem seus próprios interesses, torna-se necessário atribuir a alguém o poder-dever de curá-los. Quando estabelecida para esse fim, a representação adquire o relevo de verdadeiro mипиs, agindo o representante como se fora titular de um ofício, mas de Direito Privado, no sentido de que exerce uma função ou atividade obrigatória, investido em autêntico e indiscutível poder, na acepção técnica do termo.

Contudo, a representação legal não se circunscreve a essas hipóteses. Ocorre, igualmente, quando não está em jogo a incapacidade dos representados. O poder de agir e nome das pessoas em cuja esfera jurídico-patrimonial se devem produzir os efeitos da atividade é conferido, nesses casos, a fim de subordinar o interesse individual da pessoa capaz a um interesse superior. Atribuiu-se esse poder de representação de pessoas capazes seja no interesse do grupo, como a família ou a categoria profissional, seja no interesse de terceiros, como na falência.
}

A representação legal é considerada imprópria não somente porque a atividade jurídica do representante não se funda num poder de agir derivado da pessoa em nome de quem se exerce, senão, também, porque ele age com plena independência da vontade do representado. Por outro lado, quando se destina a prover os interesses dos incapazes, o representado não pode agir em concorrência com o representante nem impedir, ou paralisar, o exercício da representação. É, entretanto, na representação legal que se configura genuíno poder consistente na função de reger interesses alheios, o qual somente pode derivar da lei.

Essas observações críticas a propósito da representação legal ameaçam a unidade dogmática do instituto, chegando algumas vezes a sustentar que a representação legal deve ser posta fora do âmbito da representação para ser colocada em esquema diverso a se delinear com os caracteres próprios dessa figura.

Persiste, não obstante, o elemento comum de identidade do mecanismo funcional das duas espécies de representação, pelo qual os efeitos do ato praticado pelo representante incorrem na esfera jurídica do representado. Permite a existência desse elemento comum se unifiquem no mesmo instituto a representação legal e a voluntária, mas em posição de recíproca autonomia, interna, uma vez se abandonem as idéias tradicionais sobre a essência do fenômeno representativo".

239 Orlando GOMES, Introdução ao Direito Civil, $19^{\mathrm{a}}$ ed. atualizadapor Edivaldo Brito e Reginalda Paranhos de Brito, Rio de Janeiro, Forense, 2007, p. 396:

"De regra, a procuração tem como base outra relação jurídica entre o outorgante e o procurador, os contratos de mandato, locação de serviços, empreitada, agência, sociedade".

240 Orlando Gomes, Introdução ao Direito Civil, $19^{\mathrm{a}}$ ed. atualizadapor Edivaldo Brito e Reginalda Paranhos de Brito, Rio de Janeiro, Forense, 2007, p. 392:

"Conquanto se considere a atuação em nome de outrem um dos elementos necessários à configuração da representação, parte da doutrina admite-a, igualmente, quando se age, em nome próprio, por conta alheia. Diz-se, nesse caso, há representação indireta. Seu mecanismo é diferente. Agindo em seu próprio nome, o representante indireto não suscita imediatamente efeitos na esfera jurídica do representado, mas na sua própria. Só, num segundo momento, os transfere para aquela. Entre representante e representado existe um vínculo interno pelo qual o primeiro assume a obrigação de transferir os direitos e obrigações adquiridos e contraídos em nome próprio.

Representação direta e indireta distinguem-se não somente na estrutura, mas também na função. A proteção dos efeitos ocorre diferentemente, por isso que os resultados do negócio só se inserem na 
Ao presente estudo, interessa levar em conta somente as categorias de representação convencional e direita.

E renasce, neste ponto, a já descrita contenda doutrinária acerca da autonomia da representação em relação ao contrato de mandato. A doutrina brasileira, por regra, opta por ignorar a querela, e considerar a representação convencional como, também pelo menos por regra, inerente ou derivada do contrato de mandato ${ }^{241}$.

Orlando Gomes, ao revés, filiando-se aos que defendem a autonomia da representação em relação ao contrato de mandato $^{242}$, reputando-a negócio jurídico

esfera jurídico-patrimonial do representado, na representação indireta, em virtude de ato ulterior do representante, enquanto na representação direta repercutem no momento mesmo em que se produzem".

241 Sílvio de Salvo VenosA, Direito Civil-Parte Geral, $3^{\mathrm{a}}$ ed., São Paulo, Atlas, 2003, p. 395:

"A representação voluntária é baseada, em regra, no mandato, cujo instrumento é a procuração. A figura da representação não se confunde com o mandato.

O novo Código civil traz, em sua parte geral, disposições gerais sobre a representação (arts. 115 a 120), distinguindo o art. 115 essas duas formas de representação, conferidas 'por lei, ou pelo interessado'. O art. 116 aponta o efeito lógico da representação: 'A manifestação de vontade pelo representante, nos limites de seus poderes, produz efeitos em relação ao representado'. Esclarece o art. 120 que os requisitos e os efeitos da representação legal são os estabelecidos nas normas respectivas, enquanto os da representação voluntária são os da parte especial do Código, principalmente o contrato de mandato". Caio Mário da Silva PEREIRA, Instituições de Direito Civil - Introdução ao Direito Civil - Teoria Geral do Direito Civil, 22a ed. atualizada por Maria Celina Bodin de Moraes, Rio de Janeiro, Forense, 2007, p. 618:

"Dá-se a representação convencional ou voluntária, quando uma pessoa encarrega outra de praticar em seu nome negócios jurídicos ou administrar interesses, sendo normal para este efeito a constituição do mandato. (...)".

Fábio Ulhoa CoElHo, Curso de Direito Civil, vol. 1, 2ª ed., São Paulo, Saraiva, 2006, p. 299:

"Quando concedidos por lei os poderes do representante, denomina-se legal a representação, e quando concedidos pela vontade do representado, voluntária ou convencional. O negócio jurídico de outorga de poderes de representação pelo próprio representado é o contrato de mandato, que se instrumentaliza na procuração. Desse modo, o que recebe os poderes de representação, (chamado mandatário ou procurador) é o representante investido nos seus poderes por vontade própria do interessado".

Sílvio Rodrigues, Direito Civil - Parte Geral, vol. 1, 34ª ed., São Paulo, Saraiva, 2007, p. 165:

"Os poderes derivados de representação conferem-se por lei ou pelo interessado, diz o art. 115 do Código Civil, o que significa o acolhimento da clássica distinção entre representação legal e a convencional. Enquanto a primeira decorre da norma, como no caso do tutor, que representa o tutelado, ou do inventariante, que representa o espólio, ou do síndico, que representa a massa falida, encontramos a segunda, ou seja, a representação convencional, que decorre do contrato de mandato".

242 Orlando Gomes, Introdução ao Direito Civil, $19^{\mathrm{a}}$ ed. atualizada por Edivaldo Brito e Reginalda Paranhos de Brito, Rio de Janeiro, Forense, 2007, p. 393:

"Uma vez que o mandato pode envolver a representação ou não, nem sempre agindo o mandatário em nome do mandante, possível não é confundir as duas figuras jurídicas, cumprindo à doutrina distinguilas, sem embargo, de haver o legislador disposto, por equívoco, que somente se opera o mandato quando alguém recebe de outrem poderes, para, em seu nome, praticar atos ou administrar interesses.

Impõe-se a distinção não somente porque o mandato e a procuração não se justapõem necessariamente, mas, também, porque são relações jurídicas de natureza diversa que, coligadas, revelam aspectos diferentes de um fenômeno aparentemente unitário. Quando o mandatário é procurador, o vínculo entre ele e o mandante é o lado interno da relação mais extensa em que participam, enquanto o lado externo se ostenta na qualidade de procurador, em razão da qual se trata com terceiros. Nesta hipótese, o mandato é a relação subjacente à procuração. Como, porém, o poder de agir em nome de outrem encontra em outras relações jurídicas a razão de sua outorga, nascendo de negócio unilateral, não vinculado necessariamente ao mandato, sua noção é mais vasta e demanda desdobramento à parte, não 
distinto $^{243}$, conceitua-a como procuração, negócio jurídico unilateral - visto que se aperfeiçoa com a declaração de vontade do outorgante sem participação do outorgado para sua formação, sendo seu destinatário o terceiro com quem tratará o procurador - fonte do poder de representação que legitima o representante a agir em nome do representado, sendo, portanto, essa a sua causa ${ }^{244}$. Acrescenta que o negócio jurídico procuração não se confunde com a forma usual de sua exteriorização, podendo, esta sim, ser classificada em pública ou privada, conforme a dicção legal ${ }^{245}$ e que o seu destinatário é o terceiro, porque se destina a ele, ao seu conhecimento de que o procurador que se lhe apresenta tem poderes para realizar negócios jurídicos que afetem o patrimônio jurídico de quem lhe outorgou

se justificando a disciplina do poder de representação no capítulo dedicado a um contrato nominado, de causa típica, que o dispensa em muitos casos, mas, sobretudo, que o exige sempre que o mandante pretenda do mandatário que aja em seu nome".

243 Orlando Gomes, Introdução ao Direito Civil, $19^{\mathrm{a}}$ ed. atualizada por Edivaldo Brito e Reginalda Paranhos de Brito, Rio de Janeiro, Forense, 2007, pp. 393 e 394:

"Recorda-se que a distinção entre os dois lados da relação e, conseqüentemente, entre mandato e representação, foi feita, primeiramente, por Ihering, chegando a doutrina, posteriormente, devido principalmente às investigações de Laband, a reconhecer que um lado é para o outro de todo indiferente e sem nenhuma influência.

Em resultado desses estudos, ganhou foros de cidade a doutrina da autonomia da procuração, devendose reconhecer, inclusive em nosso Direito, que ela é distinta da relação jurídica subjacente entre representante e representado".

244 Orlando GoMES, Introdução ao Direito Civil, $19^{\mathrm{a}}$ ed. atualizada por Edivaldo Brito e Reginalda Paranhos de Brito, Rio de Janeiro, Forense, 2007, p. 391:

"Essa unidade dogmática, pretendida para subsumir num só esquema técnico as diversas expressões do fenômeno da cooperação jurídica, é sugerida pela identidade substancial do efeito típico da representação que consiste em suscitar, numa esfera jurídico-patrimonial alheia, os efeitos próprios do ato jurídico que o agente praticou em nome dessa pessoa.

A essência da representação essência da representação reside na atuação em nome de outro, por necessidade ou conveniência. Tal atuação exige o poder de representação o qual se funda na lei ou em negócio jurídico.

(...)

Verdadeira e própria representação é a que se estrutura no campo da autonomia privada mediante o negócio jurídico de procuração, pelo qual uma pessoa investe outra no poder de agir em seu nome.

O negócio representativo é distinto do negócio de gestão, ainda quando contextualmente unidos. Por outras palavras, a procuração é negócio autônomo em relação aos contratos subjacentes, seja o mandato, a prestação de serviços, a agência, a expedição, a preposição mercantil, e assim por diante. Essa autonomia é proclamada atualmente pela maioria esmagadora dos civilistas, e tido como irreversível conquista da ciência do direito.

A procuração é negócio unilateral, com função própria. Torna-se perfeita com a declaração de vontade de quem a outorga, embora sua eficácia somente se inicie quando toma conhecimento de sua concessão a pessoa em relação à qual o procurador exercerá o poder de representação. Pensam outros, entretanto, que destinatário da procuração é o próprio procurador, porque o terceiro pode exigir que a exiba. Como quer que seja, é declaração receptícia.

Parte da doutrina tem-na como negócio abstrato, mas na verdade possui causa própria: a de legitimar o representante a agir em nome do representado, intervindo em sua esfera jurídica. Esclarece Santoro Passarelli, que é qualificado negócio abstrato no sentido de que não tem relevância, para os terceiros que irão tratar com o procurador, a subjacente relação de gestão, o chamado contrato básico".

245 Orlando GoMES, Introdução ao Direito Civil, 19a ed. atualizada por Edivaldo Brito e Reginalda Paranhos de Brito, Rio de Janeiro, Forense, 2007, p. 394:

"Posto se designe com o mesmo nome o instrumento, público ou particular, no qual se exaram os poderes conferidos ao procurador, não é de se confundir o negócio jurídico, que contém, com a sua forma usual." 
poderes $^{246}$. E consigna o caráter de revogabilidade do negócio jurídico, decorrente da sua própria natureza, sendo que o direito brasileiro consigna tão-somente três exceções à regra: a) quando contém cláusula expressa de irrevogabilidade; b) quando a cláusula de irrevogabilidade for condição de negócio jurídico bilateral ou tiver sido estipulada no exclusivo interesse do mandatário; c) quando figura como meio de cumprimento ou confirmação de negócios encetados, aos quais se encontre vinculada ${ }^{247}$.

Desta maneira, assenta Orlando GoMEs ${ }^{248}$ os principais pontos de sua doutrina acerca do negócio jurídico procuração:

“ $1^{\circ}$ - a procuração é figura autônoma e independente do mandato, que lhe é subjacente, as mais das vezes, e se destina a regular unicamente a relação interna de gestão entre mandante e mandatário;

$2^{\circ}$ - a procuração é negócio jurídico unilateral expresso na declaração de vontade do outorgante e dirigida a terceiros;

$3^{\text {o }}$ - a função da procuração é atribuir um poder jurídico ao procurador em razão do qual pode ele adquirir direitos e contrair obrigações em nome do outorgante".

Suscita dúvida a classificação em legal ou convencional da representação oriunda da Gestão de Negócios, porque o gestor de negócios obra inicialmente sem que haja

246 Orlando GoMES, Introdução ao Direito Civil, $19^{\mathrm{a}}$ ed. atualizada por Edivaldo Brito e Reginalda Paranhos de Brito, Rio de Janeiro, Forense, 2007, p. 395:

"O destinatário da procuração é a pessoa em relação a qual deve atuar a representação. Destina-se, com efeito, ao terceiro, dado que ele precisa saber da existência e extensão dos poderes conferidos. Se toma conhecimento da procuração antes de ser comunicada ao procurador nomeado, a declaração de vontade do outorgante se torna perfeita. A obrigação imposta ao procurador de apresentar o instrumento de procuração às pessoas com as quais deva tratar em nome do outorgante tem de ser entendida no sentido restrito que lhe atribui a lei. Exige-se para fixar ou delimitar a responsabilidade do representante pelos atos praticados ale dos poderes em que se acha investido. Jamais para o aperfeiçoamento do negócio jurídico. Se tal obrigação tivesse essa finalidade, a procuração adquiriria natureza contratual. O negócio unilateral autônomo exigiria, contraditoriamente, com o suporte, uma relação contratual, visto que somente se tornaria perfeito e acabado quando o representante cumprisse a obrigação de apresentar o instrumento de seus poderes.

Tanto é destinatário o terceiro que a procuração só se torna eficaz quando o procurador lhe transmite sua condição, agindo, ao transmiti-la, na qualidade de núncio. A declaração é dirigida, realmente, à pare contrária, pois se destina a seu conhecimento. O poder de representação, que confere, tem significação principalmente em relação a terceiros".

247 Orlando GoMES, Introdução ao Direito Civil, $19^{\mathrm{a}}$ ed. atualizada por Edivaldo Brito e Reginalda Paranhos de Brito, Rio de Janeiro, Forense, 2007, p. 397:

"É a procuração, por fim, negócio jurídico que pode ser livremente revogado. Decorre a revogabilidade de sua própria natureza. A todo tempo, o outorgante pode retirar os poderes que concedeu. Irrevogável são, apenas, os negócios de outra espécie, impropriamente denominados procuração, como a procuração em causa própria, que envolve cessão de direitos. Até as procurações conferidas no interesse de terceiro são revogáveis, devendo-se conhecer que a cláusula de irrevogabilidade tem apenas eficácia relativa. No direito brasileiro, a procuração é irrevogável: a) quando contém cláusula de irrevogabilidade; b) quando é condição de um contrato bilateral; c) quando meio de cumprir uma obrigação".

248 Orlando GoMES, Introdução ao Direito Civil, $19^{\mathrm{a}} \mathrm{ed}$. atualizada por Edivaldo Brito e Reginalda Paranhos de Brito, Rio de Janeiro, Forense, 2007, p. 403. 
nenhuma outorga de poder, porém, ele representa uma pessoa, chamada dono, em nome de quem age, obrigando-o e adquirindo-lhe direitos. A outorga de poderes se dá num segundo momento, quando o dono, representado, ratifica os atos do gestor, convertendo, assim, o ato unilateral em mandato (ratihabitio mandato aequiparatur). Percebe-se que inicialmente a representação na gestão de negócios tende a se caracterizar como legal, mas depois se aproxima da convencional, o que leva Caio Mário da Silva PEREIRA ${ }^{249}$ a classificá-la como representação especial.

O Código Civil atual, diferente do velho de 1916, reservou, dentro do título referente ao negócio jurídico, um capítulo destinado à disciplina da representação ${ }^{250}$, que vai dos artigos 115 a $120^{251}$.

249 Caio Mário da Silva PereIRA, Instituições de Direito Civil - Introdução ao Direito Civil - Teoria Geral do Direito Civil, 22a ed. atualizada por Maria Celina Bodin de Moraes, Rio de Janeiro, Forense, 2007, pp. 618 e 619 :

"No campo da representação encontra lugar a gestão de negócios, que se configura na atuação oficiosa do gestor, em nome de outrem, sem ter recebido a incumbência de assim proceder. Classificá-la, como voluntária ou legal, é problema que reclama atenção, pois que é evidente a aproximação entre negotiorum gestio e o mandato. É uma figura especial, porque o gestor procede inicialmente sem o recebimento ou a outorga do poder, e arroga-se, não obstante, a representação de outrem, em cujo nome atua, e para quem adquire direitos ou contrai obrigações. A ratificação do dono tem o efeito de converter a oficiosidade da representação em mandato (ratihabitio mandato aequiparatur), e atrair assim a representação para o campo da voluntária: a conduta ex post facto do dono equivale a outorga de poderes, o que significa que até este momento havia uma representação quase-voluntária, na qual os atos do pseudo-representante, ad referendum do dono, permaneciam na expectativa da aprovação para valerem como emanados de uma representação regular. Há, contudo, uma parcela de representação legal na gestão de negócios, não só se se encarar a sua origem, a ver que lhe falta a concessão de poder por parte do dono - concessão que é fundamental na representação voluntária ou convencional - como também em razão de estabelecer a ordem jurídica que, em certos casos, o dono não tem a faculdade de recusar aprovação à interferência negotiorum gestor (quando a gestão se proponha a acudir prejuízos iminentes, ou redunde em proveito do dono do negócio ou da coisa). Atentando para tal circunstância, acentua Capitant que não é a outorga de poder, nem a ratificação da essência da representação, e por isso mesmo é lógico retirar a gestão da categoria da representação voluntária. Como não se encontra lugar perfeitamente definido em uma ou outra, parece-nos melhor admiti-la como representação especial, que de ambas se aproxima".

250 Orlando GoMES, Introdução ao Direito Civil, $19^{\mathrm{a}}$ ed. atualizada por Edivaldo Brito e Reginalda Paranhos de Brito, Rio de Janeiro, Forense, 2007, p. 405:

“(RA) As críticas procedentes, aqui, formuladas tiveram ressonância, porque o novo texto do Código civil, de 2002, destinou, na Parte Geral, um regime jurídico de representação libertando-a de sua submissão ao mandato, cuja disciplina, sendo um contrato, deveria exauri-se no campo específico desse tipo de negócio. (...)".

251 Código Civil

"Art. 115. Os poderes de representação conferem-se por lei ou pelo interessado.

Art. 116. A manifestação de vontade pelo representante, nos limites de seus poderes, produz efeitos em relação ao representado.

Art. 117. Salvo se o permitir a lei ou o representado, é anulável o negócio jurídico que o representante, no seu interesse ou por conta de outrem, celebrar consigo mesmo.

Parágrafo único. Para esse efeito, tem-se como celebrado pelo representante o negócio realizado por aquele em quem os poderes houverem sido subestabelecidos. 
O primeiro dispositivo fixa a distinção já descrita entre a representação legal e convencional, derivando a primeira da lei e a segunda da vontade do interessado, e o último, art. 120, determina que os requisitos e efeitos da representação legal derivem das pertinentes normas e da convencional, sejam os da parte especial do Código ${ }^{252}$. O artigo seguinte, 116, estabelece o efeito principal da representação, qual seja: o negócio jurídico celebrado pelo representante nos limites dos poderes de representação conferidos pelo representado atinge o patrimônio jurídico desde último ${ }^{253}$.

$\mathrm{O}$ art. 117 versa sobre o negócio jurídico consigo mesmo ou autocontratação, consubstanciado na realização de negócio jurídico pelo representante, portanto de forma a atingir o representado, tendo como receptor da declaração de vontade não um terceiro, como é o comum, mas o próprio representante. Abstratamente, o representante declara e recebe, aperfeiçoando, assim, o negócio jurídico consigo mesmo, e obrigando ou beneficiando o mandatário. $\mathrm{O}$ ordenamento jurídico brasileiro, em princípio, repudia a autocontratação, porém, excepcionalmente, reconhece-lha quando a lei ou o representado permitem-na $^{254}$.

Art. 118. O representante é obrigado a provar às pessoas, com quem tratar em nome do representado, a sua qualidade e a extensão de seus poderes, sob pena de, não o fazendo, responder pelos atos que a estes excederem.

Art. 119. É anulável o negócio concluído pelo representante em conflito de interesses com o representado, se tal fato era ou devia ser do conhecimento de quem com aquele tratou.

Parágrafo único. É de cento e oitenta dias, a contar da conclusão do negócio ou da cessação da incapacidade, o prazo de decadência para pleitear-se a anulação prevista neste artigo.

Art. 120. Os requisitos e os efeitos da representação legal são os estabelecidos nas normas respectivas; os da representação voluntária são os da Parte Especial deste Código".

252 Orlando GoMes, Introdução ao Direito Civil, $19^{\mathrm{a}}$ ed. atualizada por Edivaldo Brito e Reginalda Paranhos de Brito, Rio de Janeiro, Forense, 2007, p. 405:

“(...) Assim cada espécie de representação tem os seus requisitos e os seus efeitos estabelecidos nas normas respectivas: a legal na parte pertinente à sua natureza conforme o campo jurídico em que se apresente, Direito de Família, por exemplo; a voluntária, na Parte Especial, v.g., as normas disciplinadoras do mandato".

253 Caio Mário da Silva PEREIRA, Instituiçõoes de Direito Civil - Introdução ao Direito Civil - Teoria Geral do Direito Civil, 22a ed. atualizada por Maria Celina Bodin de Moraes, Rio de Janeiro, Forense, 2007, p. 621:

“(...) Realizado o negócio pelo representante, os direitos são adquiridos pelo representado, a cujo patrimônio se incorporam, cumprindo àquele transferir a este as vantagens e benefícios. As obrigações assumidas em nome do representante devem receber estrito cumprimento, e pela sua execução responde o seu patrimônio, em termos idênticos aos que se verificariam, se não tivesse havido a mediação do representante. (...)"

254 Caio Mário da Silva PereIRA, Instituições de Direito Civil - Introdução ao Direito Civil - Teoria Geral do Direito Civil, 22a ed. atualizada por Maria Celina Bodin de Moraes, Rio de Janeiro, Forense, 2007, pp. 623 e 624 :

"Na linha dos efeitos da representação, cabe o exame da autocontratação, que se configura no caso de o representante celebrar negócio jurídico consigo mesmo, procedendo como representante de outrem, dentro de esquema de raciocínio que seguiria esta linha: se o representante pode emitir a declaração de vontade em nome do representado, dirigida a terceiros, nada impede, abstratamente, que faça emissão 
$\mathrm{O}$ art. 118 obriga os representantes a provarem aos terceiros com quem vão celebrar negócio jurídico em nome do representado a sua qualidade de procurador, bem como a extensão dos poderes conferidos, sob pena de responderem, pessoalmente, pelos eventuais atos que praticarem em exorbitância aos desígnios do representado ${ }^{255}$.

E finalmente, o art. 119, disciplina as hipóteses de conflito de interesse entre o representante e o representado, inquinando de anuláveis os negócios jurídicos praticados, se do conflito tinha ou deveria ter ciência o terceiro, fixado em 180 dias, contados da

dirigida a si próprio, e assim, o representante proceda, sendo simultaneamente emissor e receptor da declaração volitiva. Contra essa situação se alinham várias razões de ordem prática, de ordem teórica e de ordem moral. Salienta-se a inconveniência prática do autocontrato, com a circunstância de proceder o representante em termos de confundir na sua pessoa a diversidade de interesses, normal no negócio jurídico bilateral. No plano puramente teórico, objeta-se com a falta de duas vontades distintas, requisito da formação do contrato. Na órbita moral, é de todo desaconselhável, pelo fato de ser o representante tentado a sobrepor o seu interesse ao do representado, sacrificando este último. Por ais razões, na sistemática do novo Código civil, a autocontratação, ou contrato consigo mesmo, em princípio é vedada (art. 117). O representante de vê proceder em proveito do representado. Se celebra consigo mesmo o negócio para o qual foi investido de poderes, estará traindo o representado e, desta sorte, o negócio jurídico é passível de anulação. O Código define a sua invalidade, dizendo-o anulável, não nulo de pleno direito, porque se deixa a critério do interessado atacá-lo, ou mantê-lo.

Casos há, contudo, em que a auto contratação é lícita. Em primeiro lugar quando for autorizada pelo representado. Neste caso, considera-se que o ato negocial contém duas manifestações de vontade: a do representante, contida no negócio, e a do representado, expressa na autorização. O negócio jurídico celebrado consigo mesmo não é ato unilateral. É bilateral, uma vez que nele estão presentes duas declarações de vontade.

O parágrafo único do art. 117 envolve na mesma condenação o ato, quando o representante transfere a outrem os poderes para figurar no ato, como se fosse o representado, e nele comparece pessoalmente como se se tratasse de outra parte. O negócio jurídico resultante contém dupla emissão volitiva apenas formalmente, pois na essência, o representante comparece duas vezes, como parte interessada, e na pessoa do terceiro, em quem sub-roga os poderes recebidos.

A alusão ao substabelecimento contida no parágrafo pode dar a impressão de esta proibição se aplicar tão-somente à representação convencional. Na verdade, ela se estende à representação legal, abrangendo assim os poderes convencionais substabelecidos, como qualquer outro caso de transmissão a outrem de poderes de representação".

255 Fábio Ulhoa CoElHo, Curso de Direito Civil, vol. 1, $2^{\mathrm{a}}$ ed., São Paulo, Saraiva, 2006, p. 302:

"Na hipótese de titularizar poderes relativos limitados, o representante deve observar os termos de sua investidura, não podendo excedê-los. Em princípio, o representado não está vinculado aos negócios praticados em seu nome com extrapolação dos poderes pelo representante. Por essa razão, o terceiro com quem o procurador entabular ralações pelo representado também deve acautelar-se e exigir a exibição da procuração. Se o representante não provar sua qualidade e extensão dos poderes, responderá pessoalmente pelo excesso (CC, art. 118). De qualquer modo, uma vez ciente o terceiro contratante dos limites dos poderes de representação outorgados ao mandatário, se celebrar com este negócio que os excede, não estará contratando com o representado. Este só se vincula pelos atos praticados pelo representante, os limites dos poderes de representação. (...)

Mas a questão não se esgota na regra geral de eficácia do mandato circunscrita aos limites dos poderes outorgados. Há hipóteses particulares em que o direito, para proteger a boa-fé dos contratantes (teoria da aparência) ou em vista da vulnerabilidade de um deles em face do outro (tutela dos consumidores), vincula o representado pelos atos do representante, mesmo se praticados com excesso de poderes". 
conclusão do negócio ou da cessação da incapacidade, o prazo decadencial para o pedido de anulação ${ }^{256}$.

O instituto da representação tem relevante interesse no estudo das pessoas jurídicas, uma vez que elas podem figurar como terceiros que contratam com o representante ou procurador, e nessa medida devem se cercar das cautelas descritas, bem como podem, por meio de seus órgãos, outorgar poderes de representação, para que um representante lhes celebre negócios jurídicos, com efeitos em seu patrimônio.

\subsection{Os Órgãos e a Presentação da Pessoa Jurídica}

A pessoa jurídica é detentora de personalidade e capacidade, do que decorre a habilitação pelo ordenamento jurídico para ser titular de direitos e obrigações. Não sendo, portanto, incapaz para os atos da vida civil, é que o ato constitutivo ou estatuto da pessoa jurídica estabelece a sua ação para exercer seus direitos e contrair obrigações, e ela o faz por meio de seus órgãos ${ }^{257}$, preenchidos por pessoas físicas que manifestam e declaram a vontade da pessoa jurídica, sendo ela própria, seja judicial ou extrajudicialemente ${ }^{258}$.

256 Caio Mário da Silva PEREIRA, Instituições de Direito Civil - Introdução ao Direito Civil - Teoria Geral do Direito Civil, 22a ed. atualizada por Maria Celina Bodin de Moraes, Rio de Janeiro, Forense, 2007, pp. 624 e 625 :

"O representante tem o dever de proceder no interesse exclusivo do representado, sobrepondo-o aos seus. Desde que se esboce um conflito, cumpri-lhe renunciar a representação se esta for convencional, ou pedir a substituição se vier da lei. Poderá, ainda, ocorrer que, sem abdicar da representação, o representante peça designação de outro, especificamente, para aquele negócio. Não procedendo de uma ou de outra maneira, cabe-lhe levar o fato ao conhecimento da pessoa com quem esteja tratando, presumindo-se de má-fé se se omitir. Realizado o ato negocial, dentro desse conflito de interesse, é anulável, seja no caso de ter o terceiro conhecimento do fato, à vista da comunicação do representante, ou por outras vias, seja no de convencerem as circunstâncias de que ele não o ignorava. A legitimatio ativa para a ação de anulação é do representado pessoalmente, ou de quem o venha a representar, e pode ser intentada após a cessação da incapacidade. Para a segurança da vida negocial, fica estabelecido o prazo decadencial de seis meses, a contar da conclusão do negócio ou da cessação da incapacidade (Código Civil, art. 119 e parágrafo único).

Se a pessoa com quem tratar o representante ignorava o conflito de interesses, prevalecerá o negócio praticado, por amor à sua boa-fé, mas o representante responderá perante o representado, ou seus herdeiros, pelos danos que daí provierem".

257 A. LEVy, Pessoas Jurídicas - Conceito e natureza de "Órgão” nas Sociedades, Associações Civis, Fundações e Corporações, in Revista Forense, vol. XCVIII (1944), p. 227:

"Assim como as pessoas naturais, também as pessoas jurídicas precisam, para viver, de órgãos, com os quais nascem e que, como partes integrantes, são indispensáveis à sua vida de relação.

A conceituação e a natureza dêsses 'órgãos' devem ser encontradas nos Códigos Civis. O Cód. Civil alemão a elas se refere, ao contrário do Cód. Civil brasileiro que a respeito silencia, deixando de considerar a grande importância do assunto para todo o direito das corporações, pois, comumente, no interesse da pessoa jurídica, atuam, não sómente os seus órgãos pròpriamente ditos, mas também simples pessoas naturais, sem aquêle caráter".

258 F. C. Pontes DE MIRANDA, Tratado de Direito Privado - Parte Geral - Tomo I - Introdução. Pessoas Físicas e Jurídicas, $4^{\mathrm{a}}$ ed., São Paulo, RT, 1974, p. 412:

"O órgão da pessoa jurídica não é representante legal. A pessoa jurídica não é incapaza. O poder de presentação, que êle tem, provém da capacidade mesma da pessoa jurídica; por isso mesmo, é dentro e 
Remontando o conceito de pessoa como sendo os sujeitos capazes de direito e rememorando que tanto a pessoa física quanto a pessoa jurídica são produto do ordenamento jurídico, uma vez que cabe à ordem jurídica reconhecer a capacidade, sem descurar que nem sempre todos os homens foram capazes, como, v.g. em Roma, é preciso compreender essa evolução conceitual ${ }^{259}$.

Desde o Direito Romano, a vida civil assiste a conjugação de esforços perseguindo um objetivo comum e o ordenamento confere a esses entes a condição de pessoa, o que não significa que as pessoas jurídicas sendo produto do reconhecimento do direito, não tenham seu substrato fático específico, porque assim como a pessoa física elas existem em detrimento do direito, que somente lhes reconhece e protege. Esse foi o conceito de pessoa jurídica agasalhado pelo direito alemão e acolhido pelo Código Civil brasileiro, sendo o escopo do direito a satisfação de interesses humanos ${ }^{260}$.

segundo o que se determinou no ato constitutivo, ou nas deliberações posteriores (P. OERTMANN, Allgemeiner Teil, 99. H. REHBEIN, Das Bürgerliche Gesetzbuch, I, 45; A. VON TUHR, Der Allgemeine Teil, I, 527; sem razão: G. PlANCK, Kommentar, I, $4^{\text {a }}$ ed., 73 e K. CosACK, Lehrbuch, II, $6^{\text {a }}$ ed., 497). A presentação é extrajudicial e judicial (art. 17); processualmente, a pessoa jurídica não é incapaz. Nem no é, materialmente. (...)

Se as pessoas jurídicas fôssem incapazes, os atos dos seus órgãos não seriam atos seus. Ora, o que a vida nos apresenta é exatamente a atividade da pessoas jurídicas através de seu órgãos: os atos são seus, praticados por pessoas físicas. Aquela concepção, romanística, foi ultrapassada. Os atos dos órgãos, que se não confundem com os dos mandatários das pessoas jurídcas, são atos das próprias pessoas jurídicas: têm elas vontade, que se exprime; daí a sua responsabilidade pelos atos ilícitos dêles, que sejam seus. (...)".

259 A. LEVY, Pessoas Jurídicas - Conceito e natureza de "Órgão” nas Sociedades, Associações Civis, Fundações e Corporações, in Revista Forense, vol. XCVIII (1944), p. 227:

"Pessoa', na linguagem comum, designa apenas o ser humano, mas, em sentido jurídico, compreende todo sujeito capaz de direitos. Êsse conceito corresponde à terminologia do Cód. alemão e do C.C.B. que tratam, no Titulo I, não de sujeitos capazes de direito, mas de 'pessoas', distinguindo entre pessoas naturais e jurídicas. Todavia nem todos os juristas reconhecem a idoneidade das noções de 'pessoa' e 'sujeito de direito'. GIERKE ensina: 'Personalidade é a capcacidade de ser sujeito de direitos; do reconhecimento dela pela lei resulta o direito à 'personalidade'. De fato, porém, não há pessoas que não sejam sujeitos de direito.

O Cód. Civil alemão e o C.C.B. conhecem sòmente pessoas naturais e pessoas jurídicas. A expressão 'pessoa jurídica' foi introduzida na linguagem do direito por SAVIGNY. A distinção legal entre pessoas naturais e jurídicas não significa que aquelas sejam capazes de direitos por natureza e estas sòmente mediante direito expresso, pois, em verdade, tôda 'pessoa' é jurídica, - porque a capcidade de direito é baseada na ordem jurídica, - e, por seu turno, nem sempre todos os homens foram capazes de direitos como, por exemplo, os escravos nos tempos de Roma".

260 A. LeVy, Pessoas Jurídicas - Conceito e natureza de "Órgão" nas Sociedades, Associações Civis, Fundações e Corporações, in Revista Forense, vol. XCVIII (1944), p. 228:

"Para podermos reconhecer a natureza das pessoas jurídicas fundamo-nos no axioma de JHERING de que o fim do direito é a proteção e o provimento dos interêsses humanos. O 'Corpus Juris Justiniani' reza: 'Omne jus hominum causa factum est'. Os adeptos da teoria fictícia concluíram dêsse axioma que sòmente os homens poderiam ser capazes de direito e que as pessoas jurídicas seriam pessoa fictas. Mas isso é errôneo. A frase 'omne jus hominum causa factum est' não significa que sòmente o homem é capaz de direito, mas que todo direito existe por causa de interesses humanos. Muitos resultadso só podem ser alcançados pela cooperação de várias fôrças econômicas, dada a insuficiência das capacidades do corpo e do espírito ou as fôrças econômicas do indivíduo. (...) Assim, é que vemos na 
No que concerne especificamente às pessoas jurídicas figurarem como sujeitos de direitos e obrigações, o Direito Romano consagrava a sua incapacidade, não restando esclarecida a forma como os atos praticados "em nome" dos entes abtratos afetavam o seu patrimônio jurídico. Um sujeito de direito que nem mesmo por meio de pessoas entrepostas pudesse exercer direitos e se obrigar seria de completa inutilidade, abrindo-se dessa forma o leque de exceções que permitiam às pessoas jurídicas, por exemplo, o exercício da posse e a aquisição da propriedade ${ }^{261}$.

É na Idade Média, com espeque no direito germânico, que não distinguia a totalidade de membros da unidade, sendo esta responsável pelos atos daqueles, que os Glosadores na recepção do Direito Romano terminam por adaptar a concepção antiga às demandas práticas, de modo a conceber uma teoria das corporações completamente afastada da de Roma e que consagrava a capacidade das pessoas jurídicas ${ }^{262}$.

vida cotidiana muitas associações de várias fôrças para servir a fim predeterminado. É preciso, por necessidades da vida cotidiana, conceder a essas organizaçoes a capacidade de ser portadores de direitos, transformando-as em 'pessoas'. Encontramos pessoas dessa espécie no velho direito romano: o município político (civitas, municipes) o estado (aerarium, fiscus).

Embora a personalidade das corporações seja concedida por lei, isso não significa que a pessoa jurídica não existe senão criada pela lei. A capacidade do homem é também baseada na lei, mas ele existe antes da intervenção desta. Portanto, a pessoa jurídica não é ente artificial, ficto, e sim ente real, como o homem, embora seja metafórico o têrmo 'pessoa', tais como 'cabeça de casal', 'propriedade intelectual', 'instrumento' do mandato, e outros de que o direito muitas vezes se serve.

Êsse conceito da natureza da pessoa jurídica corresponde à idéia dos Códigos Civis alemão e brasileiro, cujas prescrições sôbre as pessoas jurídicas levam a concluir que as consideram como entes reais".

261 A. LEVY, Pessoas Jurídicas - Conceito e natureza de "Órgão" nas Sociedades, Associações Civis, Fundações e Corporações, in Revista Forense, vol. XCVIII (1944), pp. 228 e 229:

"O direito romano consagrou o ponto de vista da incapacidade das pessoas jurídicas: 'universi consentire non possunt'. Mas a maneira por que os atos das pessoas que agem em nome dessas corporações têm eficiência pró e contra, no direito romano, não está suficientemente esclarecida. Concluía-se pela incapacidade: 'municipes per se possidere non possunt'. Mas no caso em que não se precisava vontade ou ato para reproduzir efeitos jurídicos, êsses efeitos podiam nascer também detrimento das pessoas jurídicas, por exemplo, por causa de enriquecimento (condictio sine causa, causa data causa non secuta) (...)

As conseqüências dessa doutrina já não eram admissíveis na antiga Roma, onde houve muitas corporações de grande desenvolvimento. O sujeito de direitos que nem mesmo por meio de representantes pudesse praticar atos jurídicos seria figura sem finalidade e sem sentido. Daí, algumas exceções que admitiam a representação a favor das pessoas jurídicas, criando, assim, um sub-rogado da capacidade, a quem se facultava a aquisição da posse e da propriedade: 'sed hoc jure utimur, ut et possidere et usucapere munícipes possint idque eis per servum et per liberum personam adquiratúr".

262 A. LEVy, Pessoas Jurídicas - Conceito e natureza de "Órgão" nas Sociedades, Associações Civis, Fundações e Corporações, in Revista Forense, vol. XCVIII (1944), p. 228:

"O direito da idade média seguiu orientacão diversa da do direito romano. No direito germânico não se distinguia entre o total dos membros e a unidade que parecia dêles inseparável. A comunidade era responsável pelos atos dos seus membros e por essa razão não se precisava de representação.

No comêçó da recepção do direito romano, as duas correntes disputaram com violência, como se pode constatar através da doutrina dos glosadores sobre a teoria das corporações, numa tentativa de adaptar o ponto de vista românico às necessidades práticas. Ensinaram que a vontade concordante dos membros era idêntica à vontade da corporação, contrariando a tese universi cosentire non possunt, pela intercalação da palavra facile. De maneira semelhante foram interpretadas outras fontes de direito 
Já na Idade Moderna, a discussão é retomada na doutrina das pessoas jurídicas, opondo-se novamente a concepção romana da incapacidade e necessidade de representação e a nóvel noção de órgão ${ }^{263}$. Neste ponto aparce a distinção entre capacidade de direito e a capacidade de agir, sendo a primeira a possibilidade de contrair direitos e a segunda a possibilidade de produzir efeitos jurídicos, ou seja, a capacidade de querer e de provar juridicamente a própria vontade, entendida a vontade como a qualidade natural de querer que não pode ser subtraída pelo direito. Por esse raciocínio, a vontade seria inerente aos homens, demandando as pessoas jurídicas de um sub-rogado criado pelo direito para participar da vida civil ${ }^{264}$.

Da solução apresentada pela doutrina e acolhida pelos ordenamentos jurídicos emerge a noção de órgão da pessoa jurídica, cuja natureza é explicada por duas teorias:

romano, a favor da capacidade da pessoa jurídica, formando-se uma teoria que, na verdade, nada mais tinha de comum com a doutrina romana".

263 A. LeVy, Pessoas Jurídicas - Conceito e natureza de “Órgão” nas Sociedades, Associações Civis, Fundações e Corporações, in Revista Forense, vol. XCVIII (1944), pp. 228 e 229:

"A teoria fundada pelos glosadores conservou-se até à idade moderna. Foi SAVIGNY quem fez ressurgir a doutrina das pessoas jurídicas do direito romano, restabelecendo o axioma de que, sendo a pessoa jurídica incapaz, precisava de representação para poder exercer direitos e deveres. Com vigorosa oposiçao se lhe antepunha a chamada 'teoria cooperativa', fundada por BESELER (1843), e ampliada por GIERKE, os quais tentaram restabelecer a doutrina da capacidade da pessoa jurídica. Contestavam êsses autores a necessidade de representação da pessoa jurídica e justificavam a sua capcidade, introduzindo a noção de 'órgão' como têrmo técnico".

(...) Em virtude dessa compreensão do direito subjetivo, os germanistas estabeleceram este axioma: a pessoa jurídica é sujeito de direitos e portanto deve poder-querer, oposto ao dos romanistas: a pessoa jurídica não pode querer e por conseguinte não pode ser sujeito de direito. (...)".

264 A. LeVy, Pessoas Jurídicas - Conceito e natureza de "Órgão" nas Sociedades, Associações Civis, Fundações e Corporações, in Revista Forense, vol. XCVIII (1944), p. 229:

"A diferença entre capacidade de direito e capacidade de agir é definida por HÖLDER da maneira seguinte: capacidade de direitosé a possibilidade de obter efeitos jurídicos; a capacidade de agir é a possibilidade de produzir efeitos ju.rídicos. Quando queremos verificar se a pessoa juridica é capaz de agir, temos, de antemão, de estudar a noção da capacidade de agir. Se capacidade de agir é a possibilidade de produzir efeitos jurídicos, isso significa que é a capacidade de provar, por atos, a vontade, com eficácia jurídica. Portanto, a capacidade exige dois elementos: 1, a capacidade de querer; $\cdot 2$, a capacidade de provar, por atos, a vontade, com eficácia jurídica.

'Vontade' é uma noção fundamental psicológica, cujas inumeráveis definições não podem ser aqui discutidas. Na linguagem vulgar, o 'querer' é uma função inerente à alma; é qualidade natural dos homens e dos animais, que não pode ser concedida nem tirada pela lei. A lei somente pode estabelecer qual a vontade juridicamente reconhecida. Portanto, a lei pode declarar incapazes pessoas com capacidade de 'querer', isto é, com vontade natural, mas não pode declarar capazes de agir os que não sejam capazes de querer. Disso resulta: nem todo sujeito com vontade natural é capaz de querer no sentido jurídico, a saber, capaz de exercer pessoalmente os atos da vida civil. Mas, sem dúvida, todo indivíduo sem vontade é incapaz, pois ninguém pode exprimir vontade que não possui. A vontade dos animais não é reconhecida pelo direito. Portanto, a possibilidade de 'ser capaz', no sentido jurídico, não resta senão aos homens.

Assim, as pessoas jurídicas que não são homens, mas associações rigorosamente distintas dos seus membros humanos, são incapazes. 'Falar-se em procedimento das pessoas é linguagem figurada'. Para poderem exercer e adquirir direitos, precisam, por falta de capacidade, dum sub-rogado, que é criado pelo direito. Chegamos, assim, a estudar de que maneira o direito tem regulado a participação das corporações na vida civil". 
uma no sentido de serem meros representantes, chamada teoria romanista, e a segunda que os denota caráter sui generis, conhecida como teoria orgânica ${ }^{265}$. Os germanistas, aliás criticaram incisivamente a mistura das noções de órgão e representante verificada no Código Civil alemão e repetida no Código Civil baralileiro, quando lançam mão da designação representante para se referir, na realidade, ao órgãa $o^{266}$.

Ocorre também que além de atuar por meio de seus órgãos, de forma limitada aos seus fins sociais ${ }^{267}$, nada impede que a pessoa jurídica também constitua representantes ${ }^{268}$

265 A. LeVy, Pessoas Jurídicas - Conceito e natureza de "Órgão" nas Sociedades, Associações Civis, Fundações e Corporações, in Revista Forense, vol. XCVIII (1944), pp. 229 e 230:

"A gerência interna das corporações e a sua participação na vida civil é feita por intermédio dos órgãos. O Cód. Civil brasileiro não usa a expressão 'órgão', mas esta aparece em outros lugares, como na lei das sociedades anônimas, (...).

O Cód. Civil alemão aceitou a noção, prescrevendo no §32: 'Os assuntos da associação, que não tenham de ser decididos pela diretoria ou por um outro órgão, serão resolvidos pela assembléia geral'. Disso resulta que 'órgãos' são aqueles incumbidos de tratar dos interêsses da corporação, de acôrdo com os estatutos. O Cód. Civil brasileiro, evitando o emprêgo da expressão, estabelece, de fato, como órgão, no art. 17, 'quem os estatutos designarem ou, não designando, seus diretores'. Além dos diretores, também outros órgãos podem ser designados para a representação interna e externa. A sua atividade é limitada à esfera dos negócios para que foram instituídos. (...)

Quanto à natureza dos órgãos, duas teorias se conhecem. Uma ensina que são meros representantes. É a chamada teoria romanista. Outra ensina que a noção de 'órgão' é de caráter sui generis, sem similar no direito individual. (...)".

266 A. LeVy, Pessoas Jurídicas - Conceito e natureza de "Órgão" nas Sociedades, Associações Civis, Fundações e Corporações, in Revista Forense, vol. XCVIII (1944), p. 230:

“Os germanistas exigem a rigorosa separação das noções 'órgão' e 'representante'. LABAND, criticando o projeto, diz: 'Na lei se lê, em muitos lugares, 'representante legal'. Nessa palavra são confundidas duas relações completamente diversas entre si, a saber, órgão e a procuração ou outorga, a qual pode ser baseada tanto em atos jurídicos, como na lei. Trata-se, na representação baseada em procuração, de relação jurídica entre duas pessoas, das quais uma está praticando atos em nome de outra. Os atos jurídicos do representante são os seus próprios atos, mas têm efeitos como se fossem os atos do representado. Na representação pelos órgãos, ao contrário, a pessoa jurídica trata ela mesma e imediatamente. A diretoria não é pessoa diferente dela para com terceiros; ela se serve do órgão como a pessoa física se serve da mão ou da boca para declarar a sua vontade. 'O mesmo explica REGELSBERGER, dizendo: 'Quando age um representante há duas pessoas: o representante e o representado, e duas vontades: o representante está fora da pessoa representada... A expressão da vontade do órgão não tem 'efeitos' para a corporação, como as resoluções dos representantes, mas é a vontade dela que se manifesta pelo órgão.

(...)

A teoria orgânica não admite a identitificação dos órgãos com os representantes. A pessoa jurídica poderia agir pelos órgãos como os homens e não precisaria de representantes. Isto é, precisamente, o que ensina ENDEMANN, com muita clareza: 'Quando as vontades de muitos homens devem colaborar vence a maioria, tal como no espírito de um homem, na luta de muitos motivos, vence o mais poderoso. Alegórica é, portanto, a vontade, aqui como lá: simples palavras para representar um fenômeno, de cuja realidade, todavia, não podemos duvidar, só porque não nos seja possível segurá-lo com as mãos”.

267 F. C. Pontes De MiRAndA, Tratado de Direito Privado - Parte Geral - Tomo I - Introdução. Pessoas Físicas e Jurídicas, $4^{\mathrm{a}}$ ed., São Paulo, RT, 1974, p. 414:

"Os poderes de presentação são limitados aos fins sociais. Não se tem de apurar, in casu, se há fim individual da pessoa jurídica; basta que caiba no fim, tal como se exprime no registro. Aliás, quanto a terceiros, só tem eficácia a limitação que se depreende da inscrição, inclusive se se trata do substabelecimento".

268 F. C. Pontes DE MiRAndA, Tratado de Direito Privado - Parte Geral - Tomo I - Introdução. Pessoas Físicas e Jurídicas, $4^{\mathrm{a}}$ ed., São Paulo, RT, 1974, p. 390: 
por meio da outorga de procuração a um membro ou estranho, que não se confundirá com a função de órgão ${ }^{269}$, sem se descurar dos empregados, que da mesma forma executam a vontade da pessoa jurídica, mas não sendo ela própria ${ }^{270}$.

É necessário, no entanto, não confundir os órgãos que são designados no ato constitutivo ou estatuto com os representantes eventualmente nomeados por quem presenta a pessoa jurídica ${ }^{271}$.

A essa relação entre o ente abstrato pessoa jurídica e seus órgãos, Caio Mário da Silva PEREIRA ${ }^{272}$ chamou de representação imprópria, visto que nessa relação não há duplicidade de vontades, não se verifica a presença de representante e representado, mas somente uma pessoa, a jurídica, declarando uma única vontade, por meio de seus órgãos.

“A pessoa jurídica pode ter, além de órgão, representantes. Aqui, os princípios da representação incidem integralmente. Tais pessoas não praticam atos da pessoa jurídica, representam-na".

269 F. C. POntes DE MiRAndA, Tratado de Direito Privado - Parte Geral - Tomo I - Introdução. Pessoas Físicas e Jurídicas, 4a ed., São Paulo, RT, 1974, p. 414:

“(...) Por outr.o lado, pode a pessoa jurídica dar procuração, com plenos poderes, a alguns, a algum membro, ou a estranho, o que de modo nenhum se confunde com a função do órgão, salvo se foi estabelecido êsse meio, de presentação normal, para o órgão".

270 A. LEVY, Pessoas Jurídicas - Conceito e natureza de "Órgão" nas Sociedades, Associações Civis, Fundações e Corporações, in Revista Forense, vol. XCVIII (1944), p. 231:

"A diferença entre órgãos e simples empregados é que o poder dos empregados é baseado em contrato de locação de serviços entre êles e a diretoria, ao passo que a competência dos órgãos tem as suas raízes nos estatutos. Portanto, não é possível verificar, somente pela sua profissão ou esfera, se uma pessoa é órgão, empregado, mandatário, etc. (...)".

271 F. C. Pontes De Miranda, Tratado de Direito Privado - Parte Geral - Tomo I - Introdução. Pessoas Físicas e Jurídicas, $4^{\mathrm{a}}$ ed., São Paulo, RT, 1974, pp. 414 e 415:

"Cumpre não se confundam os órgãos da pessoa jurídica, que são órgãos de sua vontade, tais como a diretoria e o órgão de que trata o art. 17 (órgão), e os representantes nomeados pela diretoria, ou pelos representantes-órgãos, ou pela assembléia, sem caráter de órgão (procuradores, mandatários, empregados). Se não foi designado, no ato constitutivo, o órgão, é-o a diretoria. Tal o entendimento do art. 17. É o órgão da vontade, que opera pela pessoa jurídica, dentro dos limites do fim da pessoa jurídica e dos outros limites estatutários. O que os excede não cria, para a pessoa jurídica, deveres, obrigações, ações, exceções ou situações passivas nas ações e exceções; o órgão responde aos terceiros segundo o art. 1.331-1.345, ou 1.397 e 1.398 ".

272 Caio Mário da Silva PereIRA, Instituições de Direito Civil - Introdução ao Direito Civil - Teoria Geral do Direito Civil, 22a ed. atualizada por Maria Celina Bodin de Moraes, Rio de Janeiro, Forense, 2007, pp. 617 e 618 :

“Ao referir-se às pessoas jurídicas, dizia o Código Civil de 1916 (art. 17) que são elas representadas, ativa e passivamente, por quem os estatutos designarem. Embora definida na lei civil a atuação dos órgãos estatutários como sendo representação, e como tal explicada por alguns escritores, a análise do fenômeno evidencia a ausência de caracteres elementares da representação típica. Não existe duplicidade de vontade; falta a declaração volitiva do representante em lugar da do representado, pela razão simples de que este, como ente abstrato, não pode ter outra vontade senão a do próprio órgão, dito de representação. Não se confunde, pois, esta com a figura que neste capítulo estudamos, antes se diversifica. Propomos denominá-la representação imprópria, com seus limites definidos na lei, bem como na configuração de suas atribuições. Não importa a natureza pública ou privada, civil ou empresarial, da entidade. Qualquer que seja, procede por via de alguém portador da incumbência de falar e agir em seu nome. O Código Civil de 2002 substituiu a expressão inadequada (representantes) peã correta menção aos ‘órgãos’ de deliberação e execução da pessoa jurídica (e. g., art. 54)”. 
Fábio Ulhoa COELHO ${ }^{273}$ fala em "presentante legal" para dizer que a relação que existe entre a pessoa jurídica e seus administradores e diretores, em rigorosa técnica jurídica, não se trata de representação, alertando que o "presentante" não se encontra sob a égide da mesma disciplina legal que o representante - procurador -, não lhe sendo aplicados os dispositivos dos artigos 115 a 120 do Código Civil.

Nessa matéria, porém, o pontificado na doutrina brasileira é de PONTES DE MIRANDA $^{274}$, que assim tratou do assunto:

"De ordinário, nos atos da vida, cada um pratica, por si, os atos que hão de influir, ativa ou passivamente, na sua esfera jurídica. Os efeitos resultam de atos em que o agente é presente; pois que os pratica, por ato positivo ou negativo. A regra é a presentação, em que ninguém faz o papel de outrem, isto é, em que ninguém representa.

\section{(...)}

Quando o órgão da pessoa jurídica pratica o ato, que há de entrar no mundo jurídico como ato da pessoa jurídica, não há representação, mas presentação. $\mathrm{O}$ ato do órgão não entra, no mundo jurídico, como ato da pessoa, que é órgão, ou das pessoas que compõem o órgão. Entra no mundo jurídico como ato da pessoa jurídica, porque o ato do órgão é ato seu. Ainda há presentação, e não representação, conforme já aprofundamos no Tomo I, se a pessoa física ou órgão da pessoa jurídica pratica o ato, através de mensageiro ou de aparelho automático. (...)"

273 Fábio Ulhoa CoelHo, Curso de Direito Civil, vol. 1, 2ª ed., São Paulo, Saraiva, 2006, pp. 298 e 299 : "Os órgãos de representação das pessoas jurídicas são ocupados por seres humanos que, submetidos ou não à observância do princípio majoritário, definem a vontade das associações, fundações e sociedades (...). São os seus administradores e diretores. A rigor, dispensando a mais estrita atenção ao uso técnico dos conceitos jurídicos, não se poderia chamá-los de representantes legais destas. Eles não são sujeitos de direito investidos de poder para manifestar a vontade de outro sujeito; são membros de órgão de entes não-humanos, com a atribuição de expressar a vontade destes. Não representam a pessoa jurídica; fazem presente a vontade dela. Por isso, a designação técnica mais adequada para administradores e diretores de pessoa jurídica seria de presentantes legais (Miranda, 1965, 50:385). Desse modo, no rigor da técnica jurídica mais aprimorada, uma sociedade anônima é presentada por seu diretor presidente e pode ser representada por um procurador.

(...)

O rigorismo técnico de chamar os responsáveis pela formação da vontade de entes não-humanos por presentantes legais, porém, tem sido descartado. Nos livros de doutrina, na jurisprudência e mesmo na lei, é largamente disseminado o uso da expressão representante legal para identificá-los. Em conseqüência, é necessário certa tolerância. Neste Curso, em vista de sua natureza didática, faço largo uso da expressão 'representante' no sentido vulgar. Mas, note-se, chamar os presentantes de representantes não significa desconhecer a significativa diferença que existe entre as duas hipóteses. Pelo contrário, mesmo se valendo da expressão tecnicamente inapropriada, não se pode esquecer que o responsável pela manifestação da vontade de sujeito despersonificado não se encontra sob o mesmo regime jurídico do representante investido de poderes pela lei ou por mandato. A implicação é clara e relevante: os arts. 115 a 120 do CC não se aplicam aos administradores e diretores de pessoas jurídicas, ou aos responsáveis pela manifestação da vontade dos entes despersonificados".

274 Tratado de Direito Privado - Parte Geral - Tomo III - Negócios jurídicos. Representação. Conteúdo. Forma. Prova, 3ª ed., Rio de Janeiro, Borsoi, 1970, pp. 231 e 233. 
Com essa lição reitera-se a idéia de que o órgão da pessoa jurídica é mais que um representante, é a própria pessoa jurídica exercendo sua capacidade jurídica concedida pelo ordenamento. O poder do órgão advém da nomeação por outro órgão, que pode até ser o Poder Público, mas isso em nada identifica o fenômeno da presentação com o da representação legal ${ }^{275}$.

\section{5. "Teoria da Aparência" - A (re)presentação aparente}

Como à epígrafe já se indica, este tópico se propõe a analisar a chamada "Teoria da Aparência" sob dois de seus aspectos de verificação, a representação e a presentação aparentes.

O fênomeno da aparência de direito é de construção recente ${ }^{276}$ e é produto da aceleração dos negócios e interpenetração das relações jurídicas cada vez mais complexas, sem nem sempre dar oportunidade de se proceder à necessária e diligente aferição da realidade e verdade das aparências exteriores das situações jurídicas ${ }^{277}$. Corresponde a uma necessidade jurídico-econômico-social, traduzida no ideal de justiça e eqüidade que tenta conciliar, no âmbito de conflitos de direito, os ideais de segurança e certeza ${ }^{278}$. Privilegia

275 Pontes de Miranda, Tratado de Direito Privado - Parte Geral - Tomo III - Negócios jurídicos. Representação. Conteúdo. Forma. Prova, $3^{\text {a }}$ ed., Rio de Janeiro, Borsoi, 1970, p. 260:

"Pessoa Jurídica e Órgão - O poder de representar pode provir de estatutos de pessoa jurídica (associações, fundações) ou de contrato social. O órgão da pessoa jurídica é mais do o representante. A pessoa jurídica mesma atua por intermédio do órgão, que algo é entre o representante stricto sensu e o núncio. A diferença entre êle e o representante é ineliminável (...). A nomeação por outro órgão é que estabelece o poder de órgão: a relação jurídica de organicidade aproxima-se da relação jurídica de representação, porém com ela não se identifica. Às Vezes, é o poder público que nomeia $(e . g$., Presidente do Banco do Brasil, presidentes de institutos autárquicos ou paraestatais). Tais investiduras não se confundem com as em que o nomeado representa, como o tutor, o curador e o síndico".

276 Álvaro Malheiros, Aparência de Direito, in Revista de Direito Civil, Imobiliário, Agrário e Empresarial, vol. 6 (1978), p. 48:

"Têm razão os autores quando afirmam que esse princípio é de criação recente, pois somente a partir dos últimos cem anos é que as necessidades do tráfico jurídico passaram a exigir uma fundamentação para esse princípio que faz com que a realidade seja desprezada pela aparência".

277 Álvaro Malheiros, Aparência de Direito, in Revista de Direito Civil, Imobiliário, Agrário e Empresarial, vol. 6 (1978), p. 46:

"É fácil verficar que, conforme dissemos de início, dada a rapidez dos negócios, a aceleração do tráfico, a interpenetração das relações jurídicas, com a extrema facilidade de transportes e comunicações, enfim, o ritmo vertiginoso com que se operam inúmeros negócios jurídicos hoje em dia, sem que se possa examinar, convenientemente, toda a realidade e verdade que os fenômenos exteriores manifestam, torna-se cada vez mais importante o princípio da aprência de direito. Com efeito, por ela, o Direito, reconhecendo, embora que a realidade, e com ela legítimos interesses, possam ser sacrificados à aparência, protege convenientemente os interesses também legítimos, dos terceiros de boa fé que, iludidos pela manifestação real de uma situação, aparentmente jurídica, tenham se enganado ou incorrido em erro e aceito essa aparência real, mas falsa, como verdadeira".

278 Álvaro Malheiros, Aparência de Direito, in Revista de Direito Civil, Imobiliário, Agrário e Empresarial, vol. 6 (1978), pp. 41 e 42:

"A aparência de direito viria, assim, inegavelmente corresponder a uma necessiade jurídicoeconômico-social, e seria, na verdade, a expressão de um ideal de Justiça e a consagração de um 
uma situação aparente em detrimento da realidade a fim de proteger interesses e resguardar a ordem jurídica ${ }^{279}$. E é reputada por ÁlVARO MALHEIROS ${ }^{280}$ como verdadeiro princípio geral de direito dos ordenamentos jurídicos modernos.

Um conceito que se pode construir acerca da Teoria da Aparência, com estribo nos ensinamentos de VITOR FREDERICO KÜMPEL ${ }^{281}$, é que se trata de uma proteção dispensada pelo ordenamento jurídico, em favor de terceiros de boa-fé, à validade dos negócios jurídicos celebrados sob a égide de uma situação aparente, posteriormente desconfirmada pela realidade, mas com exteriorização de tal modo a levar a sociedade como um todo a crer na seriedade da celebração.

O seu fundamento reside, por assim dizer, na necessidade de ordem eminentemente social de se conferir amparo seguro aos agentes que atuam no mercado jurídico, de modo a lhes garantir que, procedendo de modo correto, terão resguardados seus interesses pela ordem jurídica $^{282}$.

princípio de eqüidade, consubstanciados na tentativa de conciliação dos ideais de segurança e de certeza no conflito de interesses que o Direito visa a ordenar".

279 Álvaro MalHeIros, Aparência de Direito, in Revista de Direito Civil, Imobiliário, Agrário e Empresarial, vol. 6 (1978), p. 45:

"É especialmente nesse sentido de aparecer sem ser, de manifestar o que não é, de contradição entre o fenômeno exteriorizado e sua essência que a teoria da aparência do direito se desenvolveu nos últimos tempos.

Assim, todos os casos considerados como de aparência de direito apresentam, sempre, esse duplo aspecto que marca, definitivamente, a teoria da aparência como uma das aplicações, no Direito, da predominância do exterior sobre o interior, da aparência sobre a realidade, com a exteriorização de um fato, de uma realidade visível, apreensível imediatamente, em contraposição a uma realidade subjacente, não visível, não cognocível imediatamente, mas que é por ela manifestada".

280 Álvaro MalHeIRos, Aparência de Direito, in Revista de Direito Civil, Imobiliário, Agrário e Empresarial, vol. 6 (1978), p. 74:

"Assim verificado, podemos concluir que o Direito moderno recebeu - e o aceita com força cada vez maior - o princípio da aparência de direito como um autêntico princípio geral de direito e, como tal, expressão do direito natural, nascido das necessidades sociais, o formulado pelo direito científico, como instrumento do arbítrio humano".

281 Vitor Frederico KüMPEL, Teoria da Aparência no Código Civil de 2002, São Paulo, Método, 2007, pp. 57 e 58 :

“(...) Pode-se dizer que a aparência é a proteção, pelo sistema jurídico (princípios e regras), garantindo existência, validade e eficácia a determinadas relações, por haver uma exteriorização (publicidade) divorciada da realidade, a qual faz crer a todos na seriedade do negócio jurídico, pela incidência da boafé objetiva e, principalmente, ao terceiro legitimado (boa-fé subjetiva), gerando regulares efeitos econômicos diretos e indiretos, muito embora a situação protegida esteja estribada numa situação insubsistente".

282 Hélio BORGHI, Teoria da Aparência no Direito Brasileiro - Aparência de Direito e Aparência no Direito, no Direito Privado e no Direito Processual Civil. Confrontações e aplicações, inclusive na Jurisprudência, São Paulo, LEJUS, 1999, p. 43:

"O fundamento da aparência de direito está na necessidade, de ordem social, de se conferir segurança às operações jurídicas, dando amparo, concomitantemente, aos interesses legítimos daqueles agentes que procedem de modo correto num dado negócio, daí sua necessidade ao mundo jurídico para consagração do princípio da eqüidade, (...)”. 
Orlando GOMES ${ }^{283}$ encontra fundamento para o reconhecimento de efeitos jurídicos a situações aparentes, porém, na elevação a princípio geral de direito do "direito singular" que trata do herdeiro aparente, consagrado no art. 1.600 do velho Código Civil de 1916 (“São válidas as alienações de bens hereditários e os atos de administração legalmente praticados pelo herdeiro excluído antes da sentença de exclusão, mas aos co-herdeiros subsiste, quando prejudicados, o direito de demandar-lhe perdas e danos"). Lembra que desde que o caso concreto apresente as mesmas razões que inspiraram a regra no tocante ao herdeiro aparente, aplica-se-lhe, também, a mesma regra, visto que a boa-fé, a lealdade e a confiança devem inspirar os negócios jurídicos, de modo que estes comportamentos exigem proteção legal uniformizada.

Rememora o mesmo jurista que ainda não se formulou uma teoria da aparência de modo a abraçá-la de forma geral, justamente, em razão dos diversos sistemas jurídicos no âmbito dos quais se tem pretendido aplicá-la Menciona, a esse propósito, as concepções alemã, francesa e italiana ${ }^{284}$. E lembra que no direito brasileiro a teoria é aceita sem previsão em uma regra geral $^{285}$, sendo mais marcante sua incidência na seara do direito empresarial, em razão da velocidade dos negócios ${ }^{286}$.

\footnotetext{
283 Orlando Gomes, Transformações Gerais do Direito das Obrigações, São Paulo, RT, 1967, pp. 94 a 95.

284 Orlando GoMes, Transformações Gerais do Direito das Obrigações, São Paulo, RT, 1967, pp. 96 e 97.

285 Orlando GoMEs, Transformações Gerais do Direito das Obrigações, São Paulo, RT, 1967, p. 97:

"O Direito pátrio aceitou a teoria da aparência, sem, entretanto, condensá-la numa disposição geral".

286 Orlando GoMES, Transformações Gerais do Direito das Obrigações, São Paulo, RT, 1967, pp. 98 e 99:

"Consagra-se, pois, nos limites geralmente aceitos, a teoria da aparência.

É, porém, no terreno do Direito Comercial que a teoria da aparência encontra aolicações mais interessantes, em razão, segundo CALAIS-AULOY, da multiplicidade de exteriorizações, tanto materiais como legais, e da dispensa de investigação por fôrça da da rapidez dos negócios.

Importantes são os casos de exteriorização material, nos quais não existe correspondência entre a atividade do indivíduo e a realidade dos atos que pratica. Terceiros de boa-fé podem ter em conta a exteriorização e ignorar a realidade que oculta. Assim é que agem na suposição de que tratam com alguém porque outrem tem comportamento semelhante ao de mandatário, ou várias pessoas se comportam como sócios dando a impressão que constituíram pessoa jurídica verdadeira. O mandato mercantil e a sociedade são contratos que ensejam, pela exterioriazação material necessàriamente mais visível, situações favoráveis à aplicação da teoria da aparência".
} 
Já Vicente RÁO ${ }^{287}$ situa o fenômeno da aparência dentre as múltiplas espécies de hipóteses de conflito entre elementos volitivos e a declaração. Levanta os argumentos $\operatorname{contrários}^{288}$ à noção de aparência de direito, no sentido de que sobrepõe o fato ao direito, atenta contra a liberdade de consentimento e desrespeita a regra que proíbe a uma pessoa transferir mais direitos do que possui (nemo dat quod non habet; nemo ad alium transferre potest quam ipse habet) e consigna ${ }^{289}$ que mesmo assim as legislações, doutrina e jurisprudência dos diversos países do mundo têm atribuído ao fenômeno a força de princípio jurídico $^{290}$.

287 Vicente RÁo, Ato Jurídico, São Paulo, Max Limonad, 1961, pp. 233 e 234:

"Se excessivo se afigura, segundo nossa opinião, qualificar o problema das relações entre os elemenos volitivos e a declaração (mesmo com referência apenas aos terceiros) pura e simplesmente com fenômeno de aparência, bem difícil seria, contudo, negar-se de modo categórico a existência de uma sensível ligação entre o problema da aparência e o do conflito em aprêço. Nos atos por outrem praticados de boa fé com o titular de direitos aparentes, produzem-se declarações de vontade que à realidade não correspondem, pois enquanto, êste titular (agindo de boa ou má fé - é outra questão) declara, digamos, a vontade de ceder um direito que diz pertencer-lhe, - a vontade do cessionário se manifesta no sentido e na convicção honesta, mas errônea, da aquisição de um direito do qual , assim acredita, o cedente seja titular verdadeiro; e à medida em que o direito aparente penetra na circulação econômica e jurídica, mais intensamente se acentúa a boa fé e a confiança dos terceiros na existência do mesmo direito em sua legítima titularidade. Essa é, no entanto, apenas, uma das múltiplas espécies de conflito entre os elementos volitivos e a declaração, espécie que requisitos ou elementos vários peculiarmente caracterizam, ente os quais o da existência de uma situação de fato cercada de circunstâncias tais que, à vista e consideração, as pessoas de boa fé incidem escusàvelmente em êrro, tornando-a como situação de direito. Ora, apesar da vontade errônea de quem assim procede, o ordenamento, atendendo à conveniência de imprimir segurança e celeridade ao comércio jurídico e à necessidade de dispensar proteção aos interêsses legítimos, reconhece como válidos os atos dêsse modo praticados e efeitos jurídicos lhes atribui. O êrro, dessarte, é eliminado por fôrca da lei e a vontade de quem assim errou é preservada, não mediante a anulação do ato como sucede com os casos comuns de êrro-vício, mas mediante reconhecimento da eficácia das declarações que do mesmo ato formam o conteúdo".

288 Vicente RÁo, Ato Jurídico, São Paulo, Max Limonad, 1961, p. 234:

“(...) Observe-se, porém, que alguns autores repelem e condenam a noção de aparência de direito, porque, dizem, atenta contra a liberdade de consentimento, forçando o verdadeiro titular a respeitar uma operação realizada em seu prejuízo e sem o concurso de sua vontade; porque, ainda, desrespeita a regra segundo a qual ninguém pode transferir direito que não seja seu, ou mais direito do que tenha (nemo dat quod non habet; nemo ad alium transferre potest quam ipse habet); porque, finalmente consagra o triunfo do fato sôbre o direito (...)".

289 Vicente Ráo, Ato Jurídico, São Paulo, Max Limonad, 1961, p. 234 :

"Apesar dessas objeções, no entanto, a doutrina, a legislação e a jurisprudência, compelidadas pelo desenvolvimento crescente das relações de direito e, em particular, das relações econômicas, atribuiram, aos poucos, a essa noção a fôrça de princípio jurídico, ora aplicando extensivamente a máxima error communis facit jus, ora desenvolvendo o conceito da posse dos direitos, ao mesmo tempo em que o direito alemão admitiu êsse princípio em conexão com o da publicidade (designando a aparência de direito com o têrmo Rechtsschein), o dieito anglo-americano o praticou e observou como regra da equity e nos demais países a lei conferiu e vem conferindo eficácia a casos constantemente mais numerosos de aparência de direito".

290 Vicente RÁo, Ato Jurídico, São Paulo, Max Limonad, 1961, p. 247:

"h) - se a aparência de direito possui fôrça de princípio, nem porisso, sem sua aplicação, pode-se dispensar o emprêgo da máxima cautela, à vista da delicadeza da matéria e da possibilidade de se causar prejuízo injusto ao direito alheio;" 
O fenômeno somente se caracteriza e produz os efeitos quando observados seus requisitos essenciais objetivos e subjetivos ${ }^{291}$ :

"São seus requisitos essenciais objetivos: a) - uma situação de fato cercada de ciscunstâncias tais que manifestamente a apresentem como se fôra uma segura situação de direito; b) - situação de fato que assim possa ser considerada, segundo a ordem geral e normal das coisas; c) - e que, nas mesmas condições acima, apresente o titular aparente como se fôra titular legítimo, ou de direito como se realmente existisse.

São seus requisitos subjetivos essenciais: a) - a incidência em êrro de quem, de boa-fé, a mencionada situação de fato como situação de direito considera; b) - a escusabilidade dêsse êrro apreciada segundo a situação pessoal de quem nêle incorreu.

Como se vê não é apenas a boa-fé que caracteriza a proteção dispensada à aparência de direito. Não é, tampouco, o êrro escusável, tão sòmente. São êsses dois requisitos subjetivos inseparàvelmente conjugados com os requisitos objetivos referidos acima - requisitos sem os quais ou sem algum dos quais a aparência não produz os efeitos que pelo ordenamento lhe são atribuídos.

O fundamento da aparência assim caracterizada vem a ser, pois, a necessidade, de ordem social, de se conferir segurança às operações jurídicas, amparando-se, ao mesmo tempo, os interêsses legítimos dos que corretamente procedem. Essa proteção se realiza de modo peculiar porque, repetimos, enquanto nos simples casos de êrro (...) a vontade de quem nêle incide é protegida por via indireta mediante a possibilidade de anulação do ato, na aparência de direito a vontade de quem erra (supondo que o direito existe, ou que o titular ostensivo seja o titular verdadeiro) prevalece, como se realidade jurídica houvesse, e não apenas aparência. Nos têrmos expostos, portanto, a aparência de direito produz os mesmos efeitos da realidade de direito, salvo particulares restrições legais. E quando se afirma que tais efeitos são produzidos em prejuízo do titular verdadeiro, a afirmação deve ser entendida em têrmos: - o titular verdadeiro possui, normalmente, meios legais para obstar que outrem disponha de seu direito sem estar, para tanto, legitimado; mas, se por qualquer circunstância não usou ou não pôde usar dêsses meios, cumpre-lhe, é certo, respeitar a situação de quem corretamente negociou à vista e consideração da aparência de direito, mas sempre lhe resta a faculdade de reclamar do titular aparente e não legitimado, que semelhante situação causou, a reparação das perdas e danos."

291 Vicente RÁO, Ato Jurídico, São Paulo, Max Limonad, 1961, pp. 243 e 244. 
Orlando GOMES ${ }^{292}$ trata do mandato aparente e consigna que o fenômeno da aparência pode se manifestar no próprio contrato de mandato ou em algum ato praticado pelo mandatário. Recaindo a aparência no mandatário, havendo, portanto, ausência de poderes, abrem-se três possibilidades: os poderes nunca foram outorgados (inexistência do negócio jurídico procuração), foram outrogados, mas o ato padece de nulidade (invalidade do negócio jurídico procuração), ou foram outorgados, porém houve expiração do prazo $\operatorname{assinalado}^{293}$.

A aparência aplicada às hipóteses de excesso de poder demanda a incidência dos mesmos três elementos, ou seja, ato do mandatário que ultrapasse os limites dos poderes que lhe foram outorgados, condições de normalidade e o elemento psicológico, ou seja, a boa-fé do terceiro ${ }^{294}$.

E finalmente, Orlando GOMES ${ }^{295}$ leciona acerca da incidência da teoria da aparência no fenômeno da presentação das pessoas jurídicas. Enumera, para tanto, quatro situações em que julga conveniente a proteção da boa-fé dos terceiros que contrataram com o ente personalizado, sendo, porém, diversas as soluções apresentadas para cada caso, sempre com estribo na noção de aparência.

No que concerne, especificamente, à hipótese de excesso de poder do administrador de pessoa jurídica, percebe-se que o autor é parcimonioso ${ }^{296}$ em admitir a incidência da

292 Orlando GoMes, Transformações Gerais do Direito das Obrigações, São Paulo, RT, 1967, p. 99:

"Manifesta-se a aparência em relação ao próprio mandato e em relação a um ato praticado pelo mandatário. No primeiro caso, não existe mandato; é falso o procurador. No segundo, existe, mas o mandatário pratica ato excedente de seus poderes".

293 Orlando GoMES, Transformações Gerais do Direito das Obrigações, São Paulo, RT, 1967, p. 100.

294 Orlando GoMES, Transformações Gerais do Direito das Obrigações, São Paulo, RT, 1967, pp. 100 e 101.

295 Orlando GoMES, Transformações Gerais do Direito das Obrigações, São Paulo, RT, 1967, pp. 101 e 102:

"As regras de aparência aplicam-se em relação às sociedades porque, sendo pessoas jurídicas, praticam atos por intermédio de seus órgãos, os quais podem não estar constituídos regularmente ou se comporem com limitações de podêres ignorados por terceiros.

Cumpre distinguir as situações. Primeiramente, pode ocorrer a expiração do mandato dos administradores, os quais continuam, não obstante, a administrá-las. É possível, em seguida, que os administradores, jamais tenham sido investidos normalmente nos poderes que exercem. A insvestidura pode resultar, por outro lado, de ato nulo. Por fim, administradores legalmente investidos praticam atos que ultrapassam seus poderes.

Em todas essas hipóteses, julga-se conveniente proteger a boa-fé de terceiros que contratam com a sociedade. São diversas, porém, as soluções, todas, entretanto, recorrendo à noção de aparência".

296 Orlando GoMes, Transformações Gerais do Direito das Obrigações, São Paulo, RT, 1967, pp. 105 e 106:

"Sempre, portanto, que a limitação fique oculta, até por insuficiência de publicidade para terceiros que razoavelmente não poderam conhecê-la, deve a sociedade responder pelos atos dos seus diretores particados não obstante proibição do ato constitutivo, ou de qualquer alteração que haja sofrido". 
aparência de direito, o que no decorrer do estudo do caso concreto que segue restará demonstrado que não mais é a realidade nos tribunais pátrios.

\subsection{A “Teoria da Aparência” na Jurisprudência do Supremo Tribunal Federal}

No âmbito do Supremo Tribunal Federal merecem destaque três julgados que debateram a incidência da "Teoria da Aparência", tratando um da realização de negócio jurídico com (re)presentante aparente e da consequente responsabilização da pessoa jurídica, outro do herdeiro aparente e o última entrando na discussão, porém, sem solução de mérito, da citação da pessoa jurídica, tema este que encontrará marcado destaque na jurisprudência do Superior Tribunal de Justiça.

\section{a) Negócio Jurídico com (Re)presentante Aparente}

O caso ${ }^{297}$ trata da contenda envolvendo aplicadores em compra de títulos de crédito por meio de um corretor que em razão de acontecimentos supervenientes tenta suicido e vem a falecer. A sociedade financeira, ré no feito, em nome da qual agia o falecido corretor, passou a negar qualquer obrigação em relação aos autores e alegar que o falecido agia em nome próprio, fixando-se a controvérsia justamente em estabelecer as reais relações entre o corretor e a sociedade ${ }^{298}$. O recurso excepcional foi admitido sob o fundamento de que a incidência da "Teoria da Aparência" no caso concreto representaria a negativa de vigência a preceitos legais que disciplinam o contrato de mandato e as relações entre mandante e mandatário, uma vez que o a decisão atacada imputava responsabilidade

297 STF, Primeira Turma, Recurso Extraordinário n. 77.814 - São Paulo, Rel. Min. Luiz Gallotti, j. 02.04.1974:

"Ementa:

Teoria da Aparência. Acórdão que bem a aplicou. Recurso Extraordinário não conhecido”.

298 STF, Primeira Turma, Recurso Extraordinário n. 77.814 - São Paulo, Rel. Min. Luiz Gallotti, j. 02.04.1974:

"Relatório:

Relata o acórdão de fls. (...) ora recorrido, proferido em grau de de embargos infrigentes, que 'apurouse nestes autos que em 1967 a (...), ora embargante, ofereceu títulos com renda anual de 34\%, promovendo ampla publicidade, na qual sobressaía o nome de (...).

Como resultado disso, (...) recebeu quantias em dinheiro dos autores e também de outras pessoas, para serem aplicados na compra de letras de câmbio. O negócio prosperou, até surgirem os acontecimentos que levaram (...) à tentativa de suicídio e à morte, em consequiência desse gesto, fato ocorrido já em fins de 1967.

A partir daí passou a sociedade ré a negar qualquer obrigação pelas transações efetuadas entre os autores e o falecido, o que deu causa às diversas ações, por via das quais os autores reclamam as importâncias referidas.

(...)

Trata-se portanto de averiguar se há realmente responsabilidade da embargante em relação aos autores, o que depende de saber, se além de simples corretor de fundos públicos, o finado (...) agiu em nome da ré, ou pelo menos, com a sua aquiescância". 
à sociedade corretora além dos limites fixados no mandato que outorgou ao seu falecido mandatário, consigando ser da essência da "Teoria da Aparência" justamente a exorbitância da regra que fixa que o mandatário agindo em nome próprio não vincula o seu mandante, elevando à situação de verdade o que apenas é aparente e distorcendo a realidade e por conseguinte a incidência do direito ${ }^{299}$. Com espeque nas cisrcunstâncias fáticas delineadas na decisio guerreada ${ }^{300}$, especialmante na íntima relação entre o corretor,

299 STF, Primeira Turma, Recurso Extraordinário n. 77.814 - São Paulo, Rel. Min. Luiz Gallotti, j. 02.04.1974:

"Relatório:

A alegação de infração aos dispositivos relativos ao mandato e à responsabilidade de mandante pelos atos do mandatário constitui sem dúvidada tema que justifica a apreciação da causa pelo Tribunal Excelso. É que a aplicação da teoria da aparência, invocada a meu ver com interia adequação no caso, representa exatamente a negativa da aplicação das regras legais que incidem sobre as hipóteses normais da exorbitância do mandato. Pelo que as circunstâncias indicavam ser o corretor mandatário da empresa, decidiu o acórdão que esta responde pelos seus atos não obstante as restrições que incidiam sobre o mandato originalmente outorgado e apesar de não terem tido os autores o cuidado de examinálo ou haver ele sido posteriormente revogado pela mandante. É da própria natureza da teoria da aparência, acarretar o desatendimento da regra de que o mandatário que atua em seu próprio nome não vinculado o mandatnte. Ela erige à condição de verdade aquilo que é apenas aparente e distorce desse modo a solução legal porque, mudando os fatos sobre que a lei deva incidir, indiretamente está negando o teor do mandamento legal, se considerada a realidade".

300 STF, Primeira Turma, Recurso Extraordinário n. 77.814 - São Paulo, Rel. Min. Luiz Gallotti, j. 02.04.1974:

"Voto:

Com efeito, mais que mero corretor (...) foi na verdade o prórpio criador da (...) desde que se associou a (...) e outros dos seus diretores, exercendo atividades na Companhia de Crédito e Fianciadora Eletrônica, na qual todos participavam de comum acordo, mas sob a direção de (...). Daí passaram eles ao controle acionário da (...), segundo contou seu atual superintendente (...) em seu depoimento, tornando-se o falecido o maior acionista.

Além disso ele chegou a tal evidência, que se tornou presidente da empresa, deixando o cargo somente por impedimento legal, que a sua profissão de corretor de fundos públicos impunha. Mas em seu lugar elegeu o irmão, numa assembléia da qual foi o secretário, sendo certo que o próprio irmão admitiu não ser sequer acionista e não passar de 'testa de ferro' do substituído (...).

(...) utilizava-se de gabinete privativo nos escritórios da embargante, havendo na porta de sua sala uma placa inidcando o nome desta. Ainda de acordo com a sentença se verifica, que a prova apontava a prática de 'atos de autoridade' dentro da sociedade, como a feitura de impressos, cartões de natal, escolha de invólucos para guarda de títulos e toda uma série de prerrogativas, que não se coadunam cam a simples posição de um corretor, (...).

Ademais disso cumpre registrar que de conformidade com o depoimento prestado pelo próprio (...), e ainda por seu contador ao agente fiscal do imposto de renda, ele tornou-se vendendor exclusivo das letras de câmbio da sociedade em apreço, fato que os demais corretores admitiram pela declaração de que não negociaram com tais títulos.

(...)

Há mais, entretanto, ainda em relação à atuação de (...) em face da (...).

Foi constituído procurador com amplos poderes 'ad negotia', sendo exato que a revogação se operou por força ainda do impedimento legal resultante da profissão, mas sem publicidade alguma, pois a ambos interessava a crença de que eles estavam intimamente relacionados no empreendimento.

Assim, mais do que corretor, o finado criador da (...) foi o seu propulsor, confundindo-se as atividades, os negócios e intresses da sociedade, dele, (...) e dos sócios.

É forçoso admitir, em face dessa situação, que os autores estavam na firme persuasão de que ao se dirigirem ao referido corretor estavam negociando com a embargante.

(...) 
que na realidade era fundador, ex-presidente, irmão do presidente que o substituiu e procurador da socidade financeira, além da conclusão de plena incidência ao caso da “Teoria da Aparência" em detrimento da literalidade dos dispositivos legais tidos como negligenciados $^{301}$, o Ministro Relator LUIZ GALLOTTI decidiu por não conhecer do recurso extremo, por se não haver negado vigência à lei, mas, pelo contrário, por se haver bem aplicado a "Teoria da Aparência"302.

\section{b) Herdeiro Aparente}

O segundo julgado ${ }^{303}$, de pouco interesse para a discussão acerca da (re)presentação das pessoas jurídicas, versa sobre a problemática do herdeiro aparente $\mathrm{e}$

Em suma, as circunstâncias, fatos e indícios apontados levam à conclusão inarredável, de que a sociedade embargante não estava alheia ao que se passava em seus próprios escritórios, com pessoa que já exerceu até a presidência da empresa e foi seu mandatário”.

301 STF, Primeira Turma, Recurso Extraordinário n. 77.814 - São Paulo, Rel. Min. Luiz Gallotti, j. 02.04.1974:

"Voto:

Mais do que os dispositivos legais citados entretanto aplica-se com muita adequação à espécie a 'teoria da aparência', que segundo ressaltou a sentença favorece os autores”.

302 STF, Primeira Turma, Recurso Extraordinário n. 77.814 - São Paulo, Rel. Min. Luiz Gallotti, j. 02.04.1974:

"Voto:

Não se configura, portanto, o dissídio jurisprudêncial, nem se mostra que à lei tenha sido negada vigência ou que haja sido contrariada sua letra.

Não conheço do recurso".

Intressante notar que no bojo da análise do díssido jurisprudencial invocado no caso retro transcrito, vem a lume, também da Primeira Turma do Supremo Tribunal Federal, o Recurso Extraordinário n. 70.762 - Guanabara, Rel. Min. Aliomar Baleeiro, j. 06.10.1970, acórdão que pode ser considerado precurssor na aplicação da "Teoria da Aparência", embora não lhe faça menção expressa. Foi assim ementado: "CORRETOR DE TÍTULOS -É responsável pelos atos de seus operadores, que atendem ao público no interior de seu escritório. A aplicação da poupanças do comitente em negócio ilegal, tecnicamente desaconselhável e estranho às instruções recebidas, sujeita o corretor a indenizar os prejuízos daí decorrentes. - Controvérsia sobre os lucros cessantes".

303 STF, Primeira Turma, Recurso Extraordinário n. 90.706-8 - Rio de Janeiro, Rel. Min. Néri da Silveira, j. 12.08.1988 Rio de Janeiro:

"Ementa: Recurso extraordinário. Ação de petição de herança e de nulidade de escrituras de cessão de direitos hereditarios, de inventario, partilha e adjudicação do único imóvel constitutivo do espolio. Alegação de exclusão de herdeiro. Procedencia parcial da ação, condenadas as duas co-herdeiras, cedentes dos direitos hereditarios sobre o único bem inventariado, a "entregarem ao autor o que este deixou de receber, acrescido de juros legais e alugueres" auferidos até a cessão, "sem correção monetária nem perdas e danos." O acórdão reconheceu a condição de herdeiro do autor, afirmando, entretanto, que desse herdeiro retardatario não havia noticia. Quanto aos cessionarios, o aresto concluiu "que se tratava de caso tipico de aplicação da teoria da aparencia," não existindo qualquer indicio de ma-fé no negócio jurídico. (...) Os efeitos da ação de petição de herança não poderao prejudicar aquele que, de boa-fé, adquiriu do herdeiro aparente qualquer bem do espolio. Cuidando-se, na espécie, de herdeiro retardatario, que o acórdão afirmou não ser conhecido dos cessionarios e mesmo dos outros herdeiros, certo esta que, ao cederem as res os direitos hereditarios sobre todo o imóvel, procederam de boa-fé, como expressamente reconheceu o aresto. O negócio jurídico assim celebrado era efetivamen te insuscetivel de desfazimento, em virtude da petição de herança do herdeiro desconhecido julgada procedente. Cumpria assegurar ao herdeiro retardatario seu quinhao hereditario, sua participação no valor dos bens da herança, tal como decidiu a sentença. Direito, também, a participação nos frutos, até a cessão. (...)". 
atesta a validade do negócio jurídico celebrado de boa-fé por aqueles que à época se consideravam únicos herdeiros do autor da herança, resguardando ao herdeiro superveniente, desconhecido e retardatário, tão somente os direitos ao quinhão e frutos auferidos no interregno de gozo da propriedade pelos herdeiros aparentes.

c) Citação da Pessoa Jurídica

Finalmente, o terceiro julgado ${ }^{304}$ limitou-se a não conhecer de recurso que ataca acórdão estadual reconhecendo a incidência da "Teoria da Aparência" no tocante à citação dirigida a pessoa jurídica e efetivada na pessoa de empregado que se apresentou como representante da sociedade e não esboçou nenhuma ressalva no tocante à carência de poderes.

\subsection{A “Teoria da Aparência” na Jurisprudência do Superior Tribunal de Justiça}

Já no âmbito do Superior Tribunal de Justiça, é farta a jursiprudência anlisando a aplicabilidade da "Teoria da Aparência" nas mais variadas gamas de situações fáticas. Prepondera a discussão justamente acerca da citação, notificação e intimação da pessoa jurídica, especificamente no tocante à recepção dessas comunicações judiciais por pessoas que não detêm poderes para tanto.

Percebe-se que por mais de dez anos a Corte Superior oscilou seu entendimento entre a exigência de recepção da comunicação judicial por pessoa habilitada de poderes, para somente assim reconhecer a validade do ato processual ${ }^{305}$, e a aplicabilidade da

304 STF, Primeira Turma, Ag. Reg. no Agravo de Instrumento n. 513.992-1 - Distrito Federal, Rel Min. Sepúlveda Pertence, j. $1^{\circ} .03 .2005$ :

"Ementa: Recurso extraordinário: descabimento: questão decidida à luz de legislação infraconstitucional, ausente o prequestionamento dos dispositivos constitucionais tidos por vulnerados (Súmula 282), cuja violação, se ocorresse, seria reflexa ou indireta, que não viabiliza o RE".

305 STJ, Terceira Turma, Recurso Especial n. 1.253 - Rio Grande do Sul, Rel. Min. Eduardo Ribeiro, j. 12.12.1989:

"Ementa: CITAÇÃO - PESSOA JURIDICA. CONSTITUI ONUS DO AUTOR INDICAR A PESSOA QUE REPRESENTA A PESSOA JURIDICA, PODENDO RECEBER A CITAÇÃO. FEITA ESTA EM QUEM PARA ISSO NÃO SE ACHA AUTORIZADA, E NULO O ATO, SENDO IRRELEVANTE POR COMPLETO A BOA-FE DO OFICIAL DE JUSTIÇA, NADA IMPORTANDO QUE AS CIRCUNSTANCIAS DE FATO O TENHAM CONDUZIDO A EQUIVOCO".

STJ, Quarta Turma, Recurso Especial n. 9.109 - São Paulo, Rel. Min. Barros Monteiro, j. 01.10.1991:

"Ementa: CITAÇÃO. PESSOA JURIDICA. PARA QUE HAJA CITAÇÃO VALIDA DE PESSOA JURIDICA, E PRECISO QUE ELA SEJA FEITA A QUEM A REPRESENTE LEGITIMAMENTE EM JUIZO, DE ACORDO COM A DESIGNAÇÃO DO ESTATUTO OU CONTRATO SOCIAL. RECURSO ESPECIAL CONHECIDO E PROVIDO".

No mesmo sentido: STJ, Quarta Turma, Recurso Especial n. 5.061 - Minas Gerais, Rel. Min. Barros Monteiro, j. 11.12.1990; STJ, Quarta Turma, Recurso Especial n. 6.606 - Mato Grosso do Sul, Rel. Min. Barros Monteiro, j. 18.12.1990; STJ, Quarta Turma, Recurso Especial n. 7.082 - Rio Grande do Sul, Rel. Min. Barros Monteiro, j. 14.05.1991; STJ, Quarta Turma, Recurso Especial n. 6.607 - Minas 
“Teoria da Aparência”, neste caso reputando válida a comunicação processual recebida mesmo que por pessoa sem poderes, ou seja, por pessoa física que não presenta ou representa a pessoa jurídica ${ }^{306}$. Nesta hipóteses de incidência da aprência de direito

Gerias, Rel. Min. Sálvio de Figueiredo Teixeira, j. 11.06.1991; STJ, Quarta Turma, Recurso Especial n. 7.088 - Rio Grande do Sul, Rel. Min. Sálvio de Figueiredo Teixeira, j. 18.06.1991; STJ, Terceira Turma, Recurso Especial n. 7.083 - Rio Grande do Sul, Rel Min. Eduardo Ribeiro, j. 28.06.1991; STJ, Terceira Turma, Recurso Especial n. 15.696-0 - São Paulo, Rel. Min. Eduardo Ribeiro, j. 13.04.1992; STJ, Quarta Turma, Recurso Especial n. 20.071-8 - Rio Grande do Sul, Rel. Min. Sálvio de Figueiredo Teixeira, j. 29.04.1992; STJ, Quarta Turma, Recurso Especial n. 22.487-5 - Minas Gerais, Rel Min. Sálvio de Figueiredo Teixeira, j. 02.06.1992; STJ, Quarta Turma, Recurso Especial n. 30.313-1 - São Paulo, Rel. Min. Barros Monteiro, j. 17.02.1993; STJ, Terceira Turma, Recurso Especial n. 32.493-6 Rio Grande do Sul, Rel Min. Eduardo Ribeiro, j. 12.04.1993; STJ, Terceira Turma, Recurso Especial n. 33.528-4 - Amazonas, Rel Min. Waldemar Zveiter, j. 10.05.1993; STJ, Quarta Turma, Recurso Especial n. 25.731-5 - Espírito Santo, Rel Min. Barros Monteiro, j. 24.06.1993; STJ, Terceira Turma, Recurso Especial n. 35.782-9 - São Paulo, Rel. Min. Costa Leite, j. 30.08.1993; STJ, Terceira Turma, Recurso Especial n. 40.131-3 - São Paulo, Rel. Min. Costa Leite, j. 15.12.1993; STJ, Terceira Turma, Recurso Especial n. 40.291-3 - Minas Gerais, Rel. Min. Eduardo Ribeiro, j. 28.02.1994; STJ, Quarta Turma, Recurso Especial n. 41.621-3 - Rio Grande do Sul, Rel. Min. Sálvio de Figueiredo Teixeira, j. 12.04.1994; STJ, Primeira Turma, Recurso Especial n. 35.198-8 - São Paulo, Rel. Min. Humberto Gomes de Barros, j. 24.08.1994; STJ, Terceira Turma, Recurso Especial n. 39.134-2 - Bahia, Rel. p/ acórdão Min. Eduardo Ribeiro, j. 28.11.1994; STJ, Primeira Turma, Recurso Especial n. 37.274-7 - São Paulo, Rel Min. Milton Luiz Pereira, j. 22.03.1995; STJ, Quarta Turma, Recurso Especial n. 56.110-8 Paraná, Rel . Min. Ruy Rosado de Aguiar, j. 08.05.1995; STJ, Quarta Turma, Recurso Especial n. 58.459-0 - Rio de Janeiro, Rel. Min. Ruy Rosado de Aguiar, j. 09.05.1995; STJ, Terceira Turma, Recurso Especial n. 68.150-2 - Paraná, Rel. Min. Costa Leite, j. 15.08.1995; STJ, Terceira Turma, Recurso Especial n. 58.500-7 - Rio de Janeiro, Rel. p/ acórdão Min. Costa Leite, j. 05.09.1995; STJ, Terceira Turma, Recurso Especial n. 77.814 - Rio de Janeiro, Rel. Min. Costa Leite, j. 28.11.1995; STJ, Terceira Turma, Recurso Especial n. 61.127 - Minas Gerais, Rel. Min. Carlos Alberto Menezes Direito, j. 04.02.1997; STJ, Terceira Turma, Recurso Especial n. 118.415 - São Paulo, Rel. Min. Eduardo Ribeiro, j. 20.05.1997; STJ, Terceira Turma, Recurso Especial n. 91.241 - Rio de Janeiro, Rel. Min. Costa Leite, j. 26.05.1997; STJ, Terceira Turma, Recurso Especial n. 132.698 - Rio de Janeiro, Rel. Min. Eduardo Ribeiro, j. 05.08.1997; STJ, Quarta Turma, Recurso Especial n. 122.313 - Paraíba, Rel. Min. Sálvio de Figueiredo Teixeira, j. 17.02.1998; STJ, Quarta Turma, Recurso Especial n. 85.279 Rio de Janeiro, Rel. Min. Sálvio de Figueiredo Teixeira, j. 26.05.1998; STJ, Quinta Turma, Recurso Especial n. 156.970 - São Paulo, Rel. Min. José Arnaldo, j. 27.10.1998 e STJ, Terceira Turma, Recurso Especial n. 182.874 - Santa Catarina, Rel. Min. Carlos Alberto Menezes Direito, j. 06.05.1999.

306 STJ, Quarta Turma, Recurso Especial n. 14.515 - São Paulo, Rel. Min. Athos Carneiro, j. 14.09.1992: "Ementa: CITAÇÃO. PESSOA JURIDICA. TEORIA DA APARENCIA. PODE SER ADMITIDA, EXCEPCIONALMENTE, A APLICAÇÃO DA TEORIA DA APARENCIA NA CITAÇÃO DE PESSOA JURIDICA. CITAÇÃO EFETIVADA POR INTERMEDIO DA MESMA PESSOA QUE RECEBERA A NOTIFICAÇÃO PREVIA EM AÇÃO DE DESPEJO POR DENUNCIA VAZIA, EXARANDO CIENTE E UTILIZANDO O CARIMBO DA FIRMA RE, TUDO LEVANDO A CRER TRATAR-SE DE SEU GERENTE E OU ADMINISTRADOR GERAL. CIRCUNSTANCIAS DO CASO CONCRETO, VALORIZADAS NA INSTANCIA DE ORIGEM. RECURSO ESPECIAL NÃO CONHECIDO”.

E no mesmo sentido: STJ, Terceira Turma, Recurso Especial n. 5.276 - Santa Catarina, Rel. Min. Waldemar Zveiter, j. 20.11.1990; STJ, Terceira Turma, Recurso Especial n. 6.631 - Rio de Janeiro, Rel. Min. Cláudio Santos, j. 28.05.1991; STJ, Terceira Turma, Recurso Especial n. 14.662-0 - Paraná, Rel. Min. Cláudio Santos, j. 31.08.1992; STJ, Quarta Turma, Recurso Especial n. 14.975-0 - Paraná, Rel. Min. Athos Carneiro, j. 31.05.1993; STJ, Quinta Turma, Recurso Especial n. 54.322-3 - São Paulo, Rel. Min. José Dantas, j. 26.10.1994; STJ, Quarta Turma, Recurso Especial n. 40.610-2 - São Paulo, Rel. Min. Fontes de Alencar, j. 13.11.1995; STJ, Terceira Turma, Recurso Especial n. 62.464 - Rio Grande do Sul, j. 11.12.1995; STJ, Quinta Turma, Recurso Especial n. 103.285 - Distrito Federal, Rel. Min. José Dantas, j. 25.02.1997; STJ, Quarta Turma, Recurso Especial n. 96.229 - Amazonas, Rel. p/ acórdão Min. César Asfor Rocha, j. 01.04.1997 (Esta decisão foi mantida pela Corte Especial do Superior Tribunal de Justiça no Agravo Regimental nos Embargos de Divergência no Recurso Especial n. 96.229 - Amazonas, Rel. Min. Fontes de Alencar, j. 01.07.1998); STJ, Quarta Turma, Recurso Especial n. 103.624 - Goiás, Rel. Min. Barros Monteiro, j. 01.04.1997; STJ, Quarta Turma, Recurso 
percebe-se destacada cautela por parte do tribunal ${ }^{307}$, lançando mão do instituto de forma casuística conforme se extrai de alguns dos julgados colacionados ${ }^{308}$.

Intressa notar que vários dos casos enfrentados pelo Superiror Tribunal de Justiça, tanto aplicando ${ }^{309}$ como rejeitanto a "Teoria da Aparência"310, no tocante à citação de

Especial n. 103.046 - São Paulo, Rel. Min. César Asfor Rocha, j. 10.06.1997; STJ, Quarta Turma, Recurso Especial n. 146.720 - Rio de Janeiro, Rel. Min. Barros Monteiro, j. 18.11.1997; STJ, Terceira Turma, Recurso Especial n. 112.429 - Amazonas, Rel Min. Waldemar Zveiter, j. 10.02.1998; STJ, Quarta Turma, Recurso Especial n. 182.497 - Santa Catarina, Rel. Min. Sálvio de Figueiredo Teixeira, j. 13.10.1998; STJ, Terceira Turma, Recurso Especial n. 161.146 - Santa Catarina, Rel. Min. Eduardo Ribeiro, j. 05.11.1998; STJ, Terceira Turma, Recurso Especial n. 164.564 - Mato Grosso, Rel. Min. Costa Leite, j. 17.11.1998; STJ, Quarta Turma, Recurso Especial n. 178.145 - Maranhão, Rel. Min. Sálvio de Figueiredo Teixeira, j. 23.11.1998; STJ, Quarta Turma, Recurso Especial n. 111.562 Maranhão, Rel. Min. Sálvio de Figueiredo Teixeira, j. 03.12.1998; STJ, Terceira Turma, Recurso Especial n. 152.405 - Rio Grande do Sul, Rel. Min. Carlos Alberto Menezes Direito, j. 17.12.1998; STJ, Quarta Turma, Recurso Especial n. 207.388 - São Paulo, j. 18.05.1999; STJ, Quarta Turma, Recurso Especial 201.427 - Rio de Janeiro, j. 18.05.1999; STJ, Quarta Turma, Recurso Especial n. 206.525 - Paraná, Rel. Min. Ruy Rosado de Aguiar, j. 20.05.1999; STJ, Quarta Turma, Recurso Especial n. 235.742 - Rio de Janeiro, Rel. Min. Ruy Rosado de Aguiar, j. 14.12.1999 e STJ, Terceira Turma, Recurso Especial n. 254.424 - Tocantins, Rel. Min. Eduardo Ribeiro, j. 29.06.2000.

STJ, Quarta Turma, Recurso Especial n. 26.610-9 - São Paulo, Rel. Min. Athos Carneiro, j. 06.10.1992: "Ementa: CITAÇÃO. APLICAÇÃO DE TEORIA DA APARENCIA. COM A PRUDENCIA DEVIDA, E ADMISSIVEL A CITAÇÃO NA PESSOA QUE SE APRESENTA OSTENSIVAMENTE COM PODERES DE GERENCIA-GERAL OU DE REPRESENTAÇÃO DA FIRMA. MATERIA DE FATO, EXAURIDA PELO ACORDÃO E INSUSCETIVEL DE REEXAME NO AMBITO DO APELO ESPECIAL. RECURSO NÃO CONHECIDO”.

308 STJ, Quarta Turma, Recurso Especial n. 110.766 - São Paulo, Rel. Min. Ruy Rosado de Aguiar, j. 24.03.1997:

"Ementa: CITAÇÃO. PESSOA JURIDICA. PESSOA QUE SE APRESENTA COMO REPRESENTANTE DA EMPRESA. DOCUMENTOS. INTIMAÇÃO. POSSIBILIDADE DE APLICAÇÃO DA TEORIA DA APARENCIA, EM CASO COMO A DOS AUTOS, EM QUE A CITAÇÃO DA EMPRESA RE, NA AÇÃO DE INDENIZAÇÃO POR DOENÇA ADQUIRIDA NO TRABALHO, FOI EFETUADA NA PESSOA DE QUEM SE APRESENTA EM REUNIÕES PUBLICAS COMO REPRESENTANTE DA EMPRESA RE PARA RELAÇÕES TRABALHISTAS, UTILIZA O CARIMBO DA FIRMA E RECEBEU A CITAÇÃO SEM QUALQUER RESSALVA. (...) RECURSO NÃO CONHECIDO”.

STJ, Quarta Turma, Recurso Especial n. 155.521 - São Paulo, Rel. Min. Ruy Rosado de Aguiar, j. 10.02.1998:

"Ementa: CITAÇÃO. PESSOA JURIDICA. TEORIA DA APARENCIA. PECULIARIDADES DO CASO QUE JUSTIFICAM A ACEITAÇÃO DA VALIDADE DE CITAÇÃO EFETUADA NA PESSOA DE EXSOCIO DA EMPRESA, FILHO DO SEU DIRETOR, QUE CONTINUA COMPARECENDO NA SUA SEDE PARA COLABORAR COM O PAI, ONDE RECEBEU A CITAÇÃO SEM QUALQUER RESSALVA, E QUE ANTES ATENDERA AO ACIDENTE, INFORMANDO A AUTORIDADE POLICIAL SER O PROPRIETARIO DO VEICULO CAUSADOR DO FATO E EMPREGADOR DO SEU MOTORISTA. RECURSO NÃO CONHECIDO”.

STJ, Quarta Turma, Recurso Especial n. 146.463 - Rio Grande do Sul, Rel. Min. Barros Monteiro, j. 19.05.1998:

"Ementa: CITAÇÃO. COMPARECIMENTO ESPONTÂNEO. ART. 214, § 1', DO CPC. TEORIA DA APARÊECIA. Supre a falta de citação o comparecimento da parte aos autos, representada por advogada que, como tal, se apresenta, deixando patente ser inequívoco o conhecimento da demanda proposta. Procuradora estreitamente ligada à empresa-ré, inclusive por laços familiares. A nãoexibição do instrumento procuratório, por falta imputável à demandada, não pode reverter em seu prol. Não deve ser declarada a nulidade quando a parte a quem possa favorecer para ela contribuiu. Recurso especial não conhecido".

309 Recursos Especiais 5.276 - SC; 62.464 - RS; 96.229 - AM; 182.497 - SC; 161.146 - SC; 152.405 RS e $254.424-$ TO. 
pessoas jurídicas, condizem às instituições financeiras, discutindo fundamentalmente a realização do ato processual em filiais e não na sede das empresas ${ }^{311}$ e perante funcionários sem poderes de representação para receber em nome dos bancos as comunicações judiciais $^{312}$.

310 Recursos Especiais 32.493-6 - RS; 25.731-5 - ES; 41.621-3 - RS; 37.274-7 - SP; 56.110-8 - PR; 58.459-0 - RJ; 68.150-2 - PR; 77.814 - RJ; 118.415 - SP e 122.313 - PB; 85.279 - RJ.

311 STJ, Terceira Turma, Recurso Especial n. 161.146 - Santa Catarina, Rel. Min. Eduardo Ribeiro, j. 05.11.1998:

"Voto do Relator:

(...)

Jamais pude aceitar que a chamada teoria da aparência se prestasse a validar a citação, feita em quem não representa a pessoa jurídica. A lei estabelece que aquele ato, fundamental no processo, seja efetuado em quem tem poderes e não, simplesmente, pareça tê-los, o que, aliás, é extremamente vago e impreciso. A única hipótese em que isso poderia ser admitido, a meu sentir, seria quando se demonstrsse haver algum conluio, de que participasse o citando, tendente a enganar o oficial de justiça, com o propósito de retardar o processo.

Igualmente se me afigura de todo despicienda a circunstância de aquele que não tem poderes haver aceitado a citação. Disso apenas se pode concluir que a pessoa em questão absteve-se de colaborar para que o ato se praticasse corretamente. Pode ser criticável tal comportamento, mas daí a ter-se como feita a citação, que não se fez, vai enorme distância. Não há como sancionar tão gravemente a pessoa jurídica - a revelia, em nosso direito tem drásticas conseqüências - apenas porque um empregado seu, por engano ou desleixo, aceitou citação sem que o pudesse ter feito. A lei certamente não autoriza.

Por fim, também não me impressiona o argumento de que o oficial de justiça não teria meios de saber quem o representante da pessoa jurídica. O ônus de indicá-lo é do autor.

(...)

Considero, entretanto, que, tendo em vista a grande amplitude que assumiram certas empresas, notadamente as bancáris, com agências espalhadas por todo o país, a exigência de que a citação se haja de fazer sempre em sua sede, em regra na pessoa de seu presidente, cria uma dificuldade que, em verdade, não se justifica. Os gerentes das diversas agências, se se achavam autorizados a concluir os contratos, hão de encontrar-se habilitados para promover a defesa da empresa, quanto aos atos ali praticados. Seria razoável entender-se que a norma pertinente à competência (art. 101, IV, 'b') se completa com a admissão de que a citação se faça na pessoa do gerente. Trata-se de dar aplicação analógica ao disposto no citado $\$ 1^{\circ}$ do artigo 215 , recurso de integração admissível no Processo Civil. Assim como o ausente poderá ser citado na pessoa de seu gerente, administrador, mandatário ou feitor, a pessoa jurídica, em circunstâncias como as em exame, será validamente citada em gerente de sua agência, quanto o litígio diga com contratos por ela firmados. A regra, é claro, não se aplicará, quando se possa detectar alguma fraude, como o concluio entre o gerente e o autor, visando a lesar a empresa.

Reconheço que tive alguma dificuldade, inicialmente, em aceitar essa construção. Venci-a, entretanto, por se me afigurar que seria absurdo, como dito, ter-se como válida a citação pelo correio, nos termos admitidos no julgamento citado, e exigir-se que, pelo oficial de justiça, não pudesse ser efetuada na pessoa do gerente.

(...)"

312 STJ, Terceira Turma, Recurso Especial n. 118.415 - São Paulo, Rel. Min. Eduardo Ribeiro, j. 20.05.1997:

"Ementa: CITAÇÃO. PESSOA JURIDICA. E NULA A CITAÇÃO FEITA EM QUEM NÃO TEM PODERES DE REPRESENTAÇÃO DO CITANDO, NADA IMPORTANDO QUE TENHA A APARENCIA DE SER SEU REPRESENTANTE E HAJA ADMITIDO, SEM PROTESTO, A PRATICA DO ATO. IRRELEVANTE, PARA ESSE FIM, TRATAR-SE DE GERENTE DA AGENCIA EM QUE CONCLUIDO O CONTRATO A CUJO PROPOSITO SE LITIGA. O FATO IMPORTA APENAS PARA FIXAÇÃO DA COMPETENCIA TERRITORIAL". 
a) Citação via postal

Importa, ainda, registrar que o Superior Tribunal de Justiça também se ocupou de discutir a validade das citações destinadas às pessoas jurídicas e efetuadas por via postal, como faculta o Código de Processo Civil ${ }^{313}$, mas cuja correspondência não tenha sido recebida por pessoa dotada dos pertinentes poderes outorgados pela pessoa jurídica ou por quem a presente. Nesta seara, predominou o entendimento no sentido da aplicabilidade da "Teoria da Aparência" de modo a validar as citações, mesmo que não recebidas por por pessoas com poderes de presentação ou representação $o^{314}$, restanto poucos casos isolados isolados externando no caso concreto entendimento oposto ${ }^{315}$.

313 Código de Processo Civil:

"Art. 221 - A citação far-se-á:

I - pelo correio;

II - por oficial de justiça;

III - por edital.

(...)"

314 STJ, Terceira Turma, Recurso Especial n. 11.914 - São Paulo, Rel. Min. Waldemar Zveiter, j. 31.10.1991:

"Ementa: PROCESSUAL CIVIL - AÇÃO DE DESPEJO - RETOMADA DE IMOVEL COMERCIAL PESSOA JURIDICA - ESTABELECIMENTO COMERCIAL - CITAÇÃO PELO CORREIO - TEORIA DA APARENCIA - ARTIGOS 221, I, E 222, DO CPC - SENTENÇA PROFERIDA DURANTE AS FERIAS - VALIDADE - ART. 173, DO CPC.

I - CONSOLIDADO NA JURISPRUDENCIA DO SUPERIOR TRIBUNAL DE JUSTIÇA O ENTENDIMENTO NO SENTIDO DA ADMISSIBILIDADE DA CITAÇÃO, POR VIA POSTAL, DE PESSOA JURIDICA, SE OU QUANDO RECEBIDA A CARTA POR SIMPLES FUNCIONARIO DA EMPRESA. DESNECESSARIO QUE SE O FAÇA, EXCLUSIVAMENTE, POR PESSOA OU PESSOAS QUE, INSTRUMENTALMENTE OU POR DELEGAÇÃO EXPRESSA, REPRESENTAM A SOCIEDADE.

(...)

III - RECURSO NÃO CONHECIDO".

STJ, Quarta Turma, Recurso Especial n. 77.381 - Rio de Janeiro, Rel. Min. César Asfor Rocha, j. 24.06.1996:

"Ementa: PROCESSUAL CIVIL. CITAÇÃO PELO CORREIO. ART. 233 , PAR. UNICO, CPC. EMPREGADO DO REU. VALIDADE. SO E SO PORQUE A CARTA CITATORIA FOI ENTREGUE NA FILIAL DA RE E RECEBIDA POR EMPREGADO SEU, NÃO SE PODE TER POR INEXISTENTE OU NULA A SUA CITAÇÃO. DA ALTA CREDIBILIDADE RECONHECIDA A EMPRESA ESTATAL QUE PRESTA O SERVIÇO DE CORREIO E DO ESTIMULANTE EXEMPLO RECOLHIDO DA JUSTIÇA DO TRABALHO, DESDE QUE A ENTREGA SEJA EFETUADA NAS CONDIÇÕES ACIMA, MILITA A PRESUNÇÃO DE QUE FOI ATENDIDA A REGRA DO PAR. UNICO DO ART. 223 DO CPC, SENDO DO DESTINATARIO O ENCARGO DE ELIDI-LA. ESSA E A INTERPRETAÇÃO QUE MAIS SE COMPADECE COM O SISTEMA ATUAL NA SUA PRETENSÃO DE DAR MAIS PRATICIDADE AS COMUNICAÇÕES DOS ATOS JUDICIAIS POIS AS NORMAS PROCESSUAIS NÃO DEVEM SER INTERPRETADAS COM EXALTAÇÕES DESNECESSARIAS, COMO SE EM SI MESMAS ESTIVESSE O PROPRIO OBJETIVO DAS CONTENDAS, MAS CONTIDAMENTE, RESUMINDO-AS A SUA VERDADEIRA DESTINAÇÃO QUE OUTRA NÃO E SENÃO A DE COMPATIBILIZAR O SEGURO ENCAMINHAMENTO DOS FEITOS A CELERIDADE DE SUA FINALIZAÇÃO. RECURSO NÃO CONHECIDO".

E no mesmo sentido: STJ, Quarta Turma, Recurso Especial n. 54.757 - São Paulo, Rel. Min. Sálvio de Figueiredo Teixeira, j. 13.05.1997; STJ, Quarta Turma, Recurso Especial n. 161.167 - São Paulo, Rel. Min. Barros Monteiro, j. 19.03.1998; STJ, Quarta Turma, Recurso Especial n. 190.690 - Rio de Janeiro, Rel. Min. Barros Monteiro, j. 14.12.1999; STJ, Segunda Turma, Recurso Especial n. 42.391 - 
São Paulo, Rel. Min. Eliana Calmon, j. 04.04.2000; STJ, Segunda Turma, Recurso Especial n. 138.411 - Distrito Federal, Rel. Min. Eliana Calmon, j. 13.02.2001; STJ, Sexta Turma, Recurso Ordinário em Mandado de Segurança n. 8.807 - São Paulo, Rel. Min. Hamilton Carvalhido, j. 03.12.2001; STJ, Quarta Turma, Recurso Especial n. 234.577 - Minas Gerais, Rel. Min. Aldir Passarinho Junior, j. 04.12.2001; STJ, Terceira Turma, Recurso Especial n. 439.236 - Minas Gerais, Rel. Min. Nacy Andrighi, j. 01.04.2003; STJ, Segunda Turma, Recurso Especial n. 327.301 - São Paulo, Rel. Min. Eliana Calmon, j. 03.04.2003; STJ, Quarta Turma, Recurso Especial n. 582.005 - Bahia, Rel. Min. Fernando Gonçalves, j. 18.03.2004; STJ, Quarta Turma, Recurso Especial n. 678.128 - Minas Gerais, Rel. Min. Jorge Scartezzini, j. 11.10.2005; STJ, Quarta Turma, Agravo Regimental no Agravo de Instrumento n. 608.317 - São Paulo, Rel. Min. Jorge Scartezzini, j. 16.02.2006; STJ, Terceira Turma, Agravo Regimental no Agravo de Instrumento n. 711.722 - Pernambuco, Rel. Min. Humberto Gomes de Barros, j. 21.02.2006; STJ, Quarta Turma, Recurso Especial n. 915.503 - Paraná, Rel. Min. Hélio Quaglia Barbosa, j. 23.10.2007; STJ, Primeira Turma, Recurso Especial n. 913.671 - Alagoas, Rel. Min. José Delgado, j. 27.11.2007.

E o mais recente, STJ, Terceira Turma, Recurso Especial n. 1.094.308 - Rio de Janeiro, Rel. Min. Massami Uyeda, j. 19.03.2009, que na mesma linha dos precedentes fixou:

"Voto do Relator: Bem de ver, assim, que a presente controvérsia cinge-se em saber se, para a intimação prevista no $\$ 1^{\circ}$ do artigo 267 do Código de Processo Civil, em se tratando de pessoa jurídica, a carta registrada, devidamente enviada ao endereço constante da inicial e do contrato social da empresa, ainda que não recebida por representante legal da empresa, supre a exigência constante do referido dispositivo legal.

Oportuno consignar que esta a. Corte, de forma a privilegiar a teoria da aparência, considera válida a citação, bem como a intimação (em geral) na pessoa de quem se apresente perante o oficial de justiça sem manifestar qualquer ressalva quanto à inexistência de poderes para representá-la.

(...)

Veja-se, assim, que se, para a citação, principal ato de comunicação no processo, que tem o condão de efetivamente constituir a relação processual entre as partes, quando realizada pela via postal, admitese, em se tratando de pessoa jurídica, o recebimento da carta registrada (corretamente endereçada) por funcionário ou preposto, não há razão para não se aplicar tal entendimento para a presente hipótese.

Assim, partindo-se do pressuposto de que é válida a intimação pela via postal a fim de cientificar o autor acerca da necessidade de promover o prosseguimento do feito, desde que atinja tal desiderato, $e$ considerando não se mostrar crível que a carta devidamente encaminhada ao endereço da empresaautora constante de seu estatuto social e da petição inical, ainda que não recebida por seus representantes legais, não tenha chegado ao conhecimento destes, tem-se por atendida a exigência prevista no artigo $267, \S 1^{\circ}$, do $C P C$.

(...)"

Cabe destacar a manifestação da Seção de Direito Privado do Superior Tribunal de Justiça acolhendo a aplicabilidade da "Teoria da Aparência" nas hipóteses de citação por via postal realizada por meio de pessoa sem poderes de (re)presentação, já levando em conta a alteração do Código de Processo Civil com a edição da Lei 8.710/93. Assim se pronunciou a Segunda Seção no âmbito do Recurso Especial n. 119.818 - Rio Grande do Sul, Rel. Min. Carlos Alberto Menezes Direito, j. 14.10.1998:

"Ementa: Citação pelo correio. Art. 223 do Código de Processo Civil, com a redação da Lei $n^{o}$ 8.710/93.

1. Há divergência entre as Turmas que compõem a Seção de Direito Privado sobre o alcance da citação pelo correio, em se tratando de pessoa jurídica. Com a redação da Lei $n^{\circ}$ 8.710/93, que não mais exige poderes de representação, mas, sim, poderes de gerência geral ou de administração, quando o Acórdão recorrido afirma que a pessoa que recebeu a citação pelo correio era o responsável no momento, não há razão alguma para invalidar o ato. 2. Recurso especial não conhecido".

E consigna o voto condutor:

"Voto do Relator: (...) A interpretação acolhida pela 4" Turma, a meu juízo e com todo o respeito aos que entendem em sentido contrário, alcança melhor a necessidade de reduzir as áreas de conflito e, pois, o retardamento no curso do processo. Ademais, em empresas de grande porte torna-se impossível, com muita freqüência, identificar claramente quais as pessoas que têm poderes de gerência ou de administração, deixando, ainda, ao alvedrio dessas empresas uma margem muito grande de espaço para manobras irregulares, assim, por exemplo, impedir o acesso do carteiro, que não pode deter-se para esperar ser recebido por aquele que tenha osd poderes próprios, gerando, com isso, enorme dificuldade para o aperfeiçoamento da relação processual, particularmente diante de pessoas de limitados recursos. (...)". 
Destes entendimentos em sentido contrário no que concerne à validade da citação via postal, merecem destaque três julgados, que na análise do caso concreto, afastaram a incidência da "Teoria da Aparência", todos, porém, em linhas gerais, levando em conta que as correspondências foram direcionadas para endereços diversos daqueles das respectivas sedes das pessoas jurídicas que deveriam ser citadas ${ }^{316}$.

315 STJ, Terceira Turma, Recurso Especial n. 42.736-3 - Rio Grande do Sul, Rel. Min. Nilson Naves, j. 19.04.1994:

"Ementa: CITAÇÃO PELO CORREIO DE PESSOA JURIDICA. CARTA REGISTRADA ENTREGUE A FUNCIONARIO SEM PODERES DE REPRESENTAÇÃO. NULIDADE DA CITAÇÃO, A VISTA DO DISPOSTO NOS ARTS. 215, 223, PAR. 3. E 247, DO COD. DE PR. CIVIL. PRECEDENTES DO STJ. RECURSO ESPECIAL CONHECIDO PELA ALINEA A E PROVIDO".

STJ, Primeira Turma, Recurso Especial n. 57.370-0 - Rio Grande do Sul, Rel. Min. Demócrito Reinaldo, j. 26.04.1995:

"Ementa: PROCESSUAL CIVIL. AÇÃO ORDINARIA DE COBRANÇA. CITAÇÃO VIA AR. ENTREGA PESSOALMENTE AO CITANDO OU A QUEM TENHA PODERES PARA RECEBER A CITAÇÃO. DESCUMPRIMENTO DE EXIGENCIAS LEGALMENTE PREVISTAS. NULIDADE. INTELIGENCIA DOS ARTIGOS 215 E 223, PARAGRAFO UNICO, DO CPC.

I - NA CITAÇÃO FEITA PELO CORREIO, COM AVISO DE RECEPÇÃO, NÃO HA COMO SE ESCUSAR AO CUMPRIMENTO DO DISPOSTO EXPRESSAMENTE NO ARTIGO 215, COMBINADO COM O PARAGRAFO UNICO DO ARTIGO 223, AMBOS DA LEI PROCESSUAL CIVIL: O PRIMEIRO DESSES DISPOSITIVOS, POR CONDICIONAR A VALIDADE DA CITAÇÃO INICIAL AO REQUISITO DA PESSOALIDADE; E O SEGUNDO, PELA EXIGENCIA DE QUE A CARTA DE CITAÇÃO SEJA ENTREGUE AO CITANDO E TENHA DESTE A ASSINATURA DO RECIBO DE ENTREGA.

II - E PACIFICO NA DOUTRINA E NA JURISPRUDENCIA QUE, NA CITAÇÃO PELO CORREIO, COM AVISO DE RECEPÇÃO, EXIGE-SE SEJA A ENTREGA FEITA, CONTRA RECIBO, PESSOALMENTE A CITAÇÃO EM SEU NOME.

III - RECURSO PROVIDO, SEM DISCREPANCIA".

316 STJ, Quarta Turma, Recurso Especial n. 330.070 - Distrito Federal, Rel. Min. Aldir Passarinho Junior, j. 27.11.2001:

"Voto do Relator:

(...)

Na espécie em comento, estou em que há nulidade na citação.

De efeito, não se cuidou, aqui, de uma citação feita por intermédio de oficial de justiça na pessoa de alguém que, inobstante não possuísse poderes para receber citação, se apresentava como representante da ré e em tais condições foi cientificado da ação. Não.

Na hipótese em tela, para começar, o endereço constante da exordial foi o da cidade de Osasco, São Paulo, indicando, portanto, que o autor sabia que lá era a sede da empresa, onde se encontravam seus representantes legais (...). Todavia, a citação foi dirigida, e por carta com Aviso de Recebimento (AR), designando o nome da ré com o adendo 'na pessoa de seu representante legal', agência central, Setor Comercial Sul (...).

Ora, não foi declinado nem o nome do representante, não foi encaminhada para o domicílio-sede da pessoa jurídica e, por último, nem se sabe se havia mesmo um representante que assim se apresentava pela empresa e que receberia o AR, eis que, por via postal, impossível certificar-se a respeito, diferentemente do que acontece quando é efetudada pessoalmente, onde o meirinho atesta tal circunstância e goza de fé-pública.

(...)".

No mesmo sentido: STJ, Quarta Turma, Agravo Regimental no Agravo de Instrumento n. 660.152 São Paulo, Rel. Min. Fernando Gonçalves, j. 02.08.2005. 


\section{b) Entendimento Consolidado}

Toda a discussão restou pacificada pela Corte Especial do Superior Tribunal de Justiça em sede de Embargos de Divergência ${ }^{317}$ com escopo de reformar acórdão prolatado

317 STJ, Corte Especial, Embargos de Divergência em Recurso Especial n. 156.970 - São Paulo, Rel. Min. Vicente Leal, j. 02.08.2000:

"Ementa: PROCESSUAL CIVIL. CITAÇÃO. PESSOA JURÍDICA. TEORIA DA APARÊNCIA. RECEBIMENTO QUE SE APRESENTA COMO REPRESENTANTE LEGAL DA EMPRESA.

- Em consonância com o moderno princípio da instrumentalidade processual, que recomenda o desprezo a formalidades desprovida de efeitos prejudiciais, é de se aplicar a teoria da aparência para reconhecer a validade da citação da pessoa jurídica realizada em quem, na sua sede, se apresenta como sua representante legal e recebe a citação sem qualquer ressalva quanto a inexistência de poderes para representá-la em Juízo.

- Embargos de Divergência conhecidos e acolhidos".

No mesmo sentido: STJ, Corte Especial, Embargos de Divergância em Recurso Especial n. 178.145 Maranhão, Rel. Min. José Arnaldo da Fonseca, j. 25.06.2001. Neste caso, embora a maioria da Corte Especial tenha acompanhado o voto do E. Min. Relator no sentido de reconhecer a aplicabilidade da "Teoria da Aparência" no caso concreto em julgamento, interessa destacar o voto vencido do E. Min. Humberto Gomes de Barros, que abre dissidência ponderando que no caso sob julgamento a citanda era uma empresa agrícola e o ato processual se deu na pessoa de seu gerente, mais conhecido pela designação de capataz. Em seguida conclui que a "Teoria da Aparência"de fato homenageia a boa-fé, mas tem também o condão de evitar fraudes, sendo, portanto, pressuposto de sua aplicabilidade a demonstração da má-fé de quem escamoteou a realidade.

(Voto Vencido: Nestes autos, a citação efetivou-se na pessoa do gerente da fazenda mantida pela ora embargante (...).

Ora, a expressão 'gerente de fazenda' é um eufemismo moderno, para designar o capataz. Capataz todos o sabemos - é o peão qualificado, normalmente um indivíduo afeito à vida bucólica, completamente alheio aos caprichos citadinos - tanto mais àqueles que se desenvolvem no labirinto processual. Entregar-lhe um mandado de citação, dirigida ao patrão é contar com a quase certeza de que o empregador demandado não responserá à citação. (...)

No caso, o receptor da citação foi o capataz. Ele foi chamado a se defender em juízo. Tenho para mim que a defesa em juízo não integra o rol das operações normais de sua atividade. Em meus trinta anos de advocacia vivenciei várias tentativas de utilização da teoria da aparência, para fraudar os preceitos acauteladores da citação. A abertura que se pretende consumar, embora se inspire em belíssimas intenções, pode levar a indesejáveis exageros.

Não podemos esquecer a função didática do Superior Tribunal de Justiça. Hoje, enxergamos excepcionalidade na citação do capataz, amanhã, os juízos locais estarão ampliando a exceção para hipótese em que ela se fez na pessoa de qualquer peão boiadeiro.

Tenho para mim que a teoria da aparência homenageia a boa-fé. Só é oportuna, quanado se trata de obviar fraudes. Seu emprego tem como pressuposto a demonstração de má-fé. Não é lícita sua utilização para derrogar regras legais, concebidas em homenagem à segurança processual.

(...)".

E ainda: STJ, Corte Especial, Agravo Regimental nos Embargos de Divergência em Recurso Especial n. 205.275 - Paraná, Rel. Min. Eliana Calmon, j. 18.09.2002. No acórdão do Recurso Epecial (Quarta Turma, j. 07.08.2001) deste caso, cumpre ressaltar a judiciosa construção teórica acrca da "Teoria da Aparência" lavrada pelo E. Relator Min. Ruy Rosado de Aguiar, que sintetiza o entendimento consagrado no âmbito do Superior Tribunal de Justiça acerca do tema:

"A teoria da aparência, fundada na força da veracidade dos fatos assim como reconhecidos e na legitimidade das condutas que se repetem e são aceitas pelo que parecem ser, embora sem a formalidade ou sem a documentação exigida para cada caso, essa teoria deve ser aplicada sempre que as ciscunstâncias evidenciam que as pessoas envolvidas, obedecendo ao padrão de cuidado exigido, tinham fundadas razões para, de boa-fé, confiar na prática de ato lícito, de acordo com a ordem jurídica. Na citação de pessoa jurídica (que a lei admite seja feita pelo correio na pessoa de administrador ou gerente geral, art. 223, § único, do CPC), é válida qunado efetuada na pessoa de quem é tido na cidade como representante da empresa ré, é seu procurador (embora só meses depois 
em sede de Recurso Especial que afastou a incidência da "Teoria da Aparência" para firmar a eesencialidade do ato processual da citação e a necessidade de que seja ele efetuado em pessoa física a que o estatuto ou contrato social da pessoa jurídica conferiu expressos poderes de (re)presentação ${ }^{318}$. O voto condutor, reconhecendo a divergência de entendimentos instalada entre os órgãos fracionários do tribunal e salientando tratar-se de discussão antiga, já tendo sido alvo de inúmeros pronunciamentos, homenageou o princípio da Justiça e o papel criador da jurisprudência como fonte do direito ${ }^{319}$. Concluiu, então, por aplicar a "Teoria da Aparência" e afastar os formalismos capazes de entravar a realização do ato jurídico processual, ainda mais no caso concreto julgado em que a pessoa física que recebeu a citação, embora não detivesse os petinentes poderes recebidos da pessoa jurídica citanda, ostentava a condição de pai do real representante, fiador da

tenha recebido poderes para citação), assina sem qualquer impugnação, recebe contra-fé e apóe o carimbo da empresa. (...)".

318 STJ, Corte Especial, Embargos de Divergência em Recurso Especial n. 156.970 - São Paulo, Rel. Min. Vicente Leal, j. 02.08.2000:

"Relatório: Em sede de embargos à execução ajuizados por (...) nos autos de ação de despejo por falta de pagamento sob alegação de nulidade da citação, o R. Juízo processante julgou procedente o pedido.

A egrégia Oitava Câmara do Segundo Tribunal de Alçada Civil do Estado de São Paulo, em sede de apelação, reformou a sentença para julgar improcedentes os embargos, ao reconhecer, invocando a palicação da teoria da aprência da pessoa jurídica, a validade da citação realizada na pessoa que se apresentou como representante legal da empresa locatária, frente a sua condição de pai do verdadeiro representante e de fiador do contrato de locação.

Interposto recurso especial, a Quinta Turma deste Tribunal cassou o acórdão recorrido para restabelecer a sentença que decretou a nulidade da citação na ação de conhecimento, ao entendimento de que a citação da pessoa jurídica deve ser realizada em quem detém poderes para representá-la legitimamente em Juízo. (...)

Irresignado, o recorrido interpõe os presentes embargos de divergência, sustentando que o acórdão em destaque divergiu do pensamento consagrado pel Eg. Quarta Turma desta Corte, que tem entendido ser válida a citação de pessoa jurídica efetivada em quem não tinha qualidade para representá-la, aplicando ao caso a teoria da aparência. (...)'.

319 STJ, Corte Especial, Embargos de Divergência em Recurso Especial n. 156.970 - São Paulo, Rel. Min. Vicente Leal, j. 02.08.2000:

"Voto do Relator: A divergência encontra-se sobejamente demonstrada. Os acórdãos colacionados tratam do mesmo tema e proclamam tese diversa da sufragada no acórdão embargado.

Neste, foi proclamado a tese de que a validade da citação da pessoa jurídica requer sua realização em quem detenha poderes para legitimamente representá-la em Juízo, de acordo com a deseignação do estatuto ou contrato social.

Por outro lado, os acórdãos paradigmas invocados sufragam o entendimento no sentido de que, em certos casos, é de se invocar a teoria da aparência para reconhecer a eficácia da citação da empresa na pesoa que na sede daquela, se apresenta como sua representante, recebe contra-fé e nada ressalva quanto à circunstância de não possuir poderes de representação.

A questão é antiga. Sobre ela, a maioria das Turmas deste Tribunal já emitiram pronunciamento. Controvertida, num primeiro tempo, no sentido de se exigir a citação da empresa na pessoa com poderes para representá-la, terminou por consolidar-se na linha de entendimento afirmado nos acórdãos paradigmas que admitiem a aplicação da teoria da aparência.

Ora, o direito deve buscar a expressão da justiça. Deve o intérprete da norma jurídica buscar o sentido que a mesma visa a atingir no cenário da vida. E, por isso, a jurisprudência deve ser fonte criadora do direito, abrindo espaço para as grandes consquistas da humanidade, com os olhos nos princípios modernos da economia processual e da instrumentalidade, que recomendam o desprezo a meras formalidades desprovidas de efeitos prejudiciais". 
obrigação que dera origem à contenda judicial, além de haver se apresentado ao Oficial de Justiça como representante, sem externar qualquer contradita no tocante a ausência de poderes $^{320}$.

Pacificada a questão pela Corte Especial, advém copiosa jurisprudência do Superior Tribunal de Justiça no mesmo sentido de aplicar a "Teoria da Aparência" nas hipóteses em que o ato de citação da pessoa jurídica tenha recaído em pessoa física sem poderes de (re)presentação, mas que não tenha ressalvada essa sua condição ao Oficial de Justiça responsável pela diligência processual ${ }^{321}$. Em muitos poucos e específicos julgados,

320 STJ, Corte Especial, Embargos de Divergência em Recurso Especial n. 156.970 - São Paulo, Rel. Min. Vicente Leal, j. 02.08.2000:

"Voto do Relator: Dentro dessa visão teleológica, a redação do artigo 215, do CPC, deve ser interpretada em consonância com a aplicação da teoria da aparência, de modo a assegurar eficácia do ato citatório livre dos entraves formalistas, a fim de que não se transforme em letra morta, gerando ônus desnecessários às partes.

Daí porque, em certas situações, é de se reconhecer a validade da citação da pessoa jurídica quando realizada em pessoa que, em sua sede, se apresenta como sua representante legal e recebe a citação sem qualquer ressalva quanto a inexistência de poderes para representá-la em Juizo, mormente quando plenamente eficaz o ato citatório.

(...)

In casu, justifica-se a aplicação da teoria da aparência na hipótese em que a citação da ação de despejo é efetuada no escritório da empresa locatária na pessoa do pai de seu representante legal, fiador do contrato locatício, e que se apresentou ao Oficial responsável pelo cumprimento da diligência como o legítimo representante, recebendo, via de conseqüencia, a citação sem qualquer ressalva".

321 STJ, Segunda Turma, Recurso Especial n. 241.701 - São Paulo, Rel. Min. Francisco Peçanha Martins, j. 07.11.2002:

"Ementa: PROCESSUAL CIVIL - EMBARGOS À EXECUÇÃO FISCAL - PESSOA JURÍDICA CITAÇÃO E INTIMAÇÃO DA PENHORA - EFETIVAÇÃO EM PESSOA QUE SE APRESENTA COMO REPRESENTANTE LEGAL DA EMPRESA - CPC, ART. 215 - PRECEDENTE DA EG. $1^{a}$ SEÇÃO.

- Impõe-se reconhecer a validade da citação e intimação da pessoa jurídica realizada em quem, na sua sede, se apresenta como sua representante legal e recebe a citação sem qualquer manifestação a respeito da falta de poderes de representação em Juízo.

- Aplicação do princípio da instrumentalidade processual em consonância com a aplicação da teoria da aparência.

- Recurso especial não conhecido".

E no mesmo sentido: STJ, Quarta Turma, Recurso Especial n. 316.036 - Rio de Janeiro, Rel. Min. Aldir Passarinho Junior, j. 11.09.2001; STJ, Terceira Turma, Agravo Regimental no Agravo de Instrumento n. 378.217 - Rio de Janeiro, Rel. Min. Antônio de Pádua Ribeiro, j. 12.11.2001; STJ, Quarta Turma, Recurso Especial n. 341.654 - Bahia, Rel. Min. Ruy Rosado de Aguiar, j. 06.04.2002; STJ, Segunda Turma, Recurso Especial n. 302.403 - Rio de Janeiro, Rel. Min. Eliana Calmon, j. 04.06.2002; STJ, Terceira Turma, Recurso Especial n. 418.021 - São Paulo, Rel. Min. Nacy Andrighi, j. 29.11.2002; STJ, Quarta Turma, Agravo Regimental no Agravo de Instrumento n. 441.507 - Rio de Janeiro, Rel. Min. Aldir Passarinho Junior, j. 06.02.2003; STJ, Primeira Turma, Recurso Especial n. 502.823 - Rio Grande do Sul, Rel. Min. José Delgado, j. 04.09.2003; STJ, Quinta Turma, Agravo Regimental no Agravo de Instrumento n. 547.864 - Distrito Federal, j. 16.03.2004; STJ, Terceira Turma, Agravo Regimental no Agravo de Instrumento n. 535.833 - São Paulo, Rel. Min. Nancy Andrighi, j. 16.03.2004; STJ, Terceira Turma, Agravo Regimental no Agravo de Instrumento n. 590.220 - Rio de Janeiro, Rel. Min. Antônio de Pádua Ribeiro, j. 14.09.2004; STJ, Terceira Turma, Agravo Regimental no Agravo de Instrumento n. 598.220 - Rio de Janeiro, Rel. Min. Carlos Alberto Menezes Direito, j. 16.09.2004; STJ, Terceira Turma, Recurso Especial n. 547.442 - Tocantins, Rel. Min. Nancy Andrighi, j. 21.09.2004; STJ, Quarta Turma, Recurso Especial n. 316.254 - São Paulo, Rel. Min. Barros 
sempre levando em consideração as idiossincrasias do caso concreto, a Corte Superior deixou de fazer incidir a "Teoria da Aparência".

O primeiro deles trata da anulação do ato de citação realizado em pessoa que nem sequer era empregada da pessoa jurídica citanda, no caso uma companhia de navegação estrangeira, restando consignado que a parte autora, um seguradora, poderia e deveria ter buscado a informação correta acerca da representação legal da citanda ${ }^{322}$.

Monteiro, j. 21.10.2004; STJ, Quarta Turma, Agravo Regimental no Agravo de Instrumento n. 618.317 - Minas Gerais, Rel. Min. Jorge Scartezzini, j. 23.11.2004; STJ, Segunda Turma, Recurso Especial n. 741.732 - São Paulo, Rel. Min. Eliana Calmon, j. 07.06.2005; STJ, Terceira Turma, Recurso Especial n. 681.639 - Santa Catarina, Rel. Min. Carlos Alberto Menezes Direito, j. 28.06.2005; STJ, Terceira Turma, Recurso Especial n. 660.014 - Santa Catarina, Rel. Min. Nacy Andrighi, j. 13.09.2005; STJ, Primeira Turma, Recurso Especial 817.284 - Minas Gerais, Rel. Min. Francisco Falcão, j. 21.03.2006; STJ, Quarta Turma, Agravo Regimental no Agravo de Instrumento n. 712.646 - Rio de Janeiro, Rel. Min. Jorge Scartezzini, j. 20.06.2006; STJ, Quinta Turma, Recurso Especial n. 439.640 - Minas Gerais, Rel. Min. Arnaldo Esteves Lima, j. 12.09.2006; STJ, Primeira Turma, Agravo Regimental no Recurso Especial n. 626.378 - Paraná, Rel. Min. Denise Arruda, j. 17.10.2006; STJ, Quarta Turma, Agravo Regimental no Recurso Especial n. 658.252 - Bahia, Rel. Min. Quaglia Barbosa, j. 06.02.2007; STJ, Terceira Turma, Recurso Especial n. 676.208 - Santa Catarina, Rel. Min. Carlos Alberto Menezes Direito, j. 13.02.2007; STJ, Quarta Turma, Agravo Regimental no Recurso Especial 869.500 - São Paulo, Rel. Min. Quaglia Barbosa, j. 13.02.2007; STJ, Segunda Turma, Recurso Especial n. 618.202 Rio Grande do Sul, Rel. Min. Herman Benjamin, j. 19.06.2007; STJ, Segunda Turma, Recurso Especial 892.314 - Minas Gerais, Rel. Min. Humberto Martins, j. 21.06.2007; STJ, Primeira Turma, Recurso Especial n. 739.397 - Rio de Janeiro, Rel Min. Teori Albino Zavascki, j. 26.06.2007; STJ, Quarta Turma, Agravo Regimental no Agravo de Instrumento n. 846.487 - Rio de Janeiro, Rel. Min. Aldir Passarinho Junior, j. 15.05.2007; STJ, Primeira Turma, Agravo Regimental no Agravo de Instrumento n. 736.583, Rel. Min. Luiz Fux, j. 14.08.2007; STJ, Quinta Turma, Recurso Especial n. 834.482 - Rio Grande do Norte, Rel Min. Arnaldo Esteves Lima, j. 06.09.2007; STJ, Primeira Turma, Agravo Regimental no Recurso Especial n. 931.295 - Rio de Janeiro, Rel. Min. Francisco Falcão, j. 06.12.2007; STJ, Terceira Turma, Agravo Regimental no Recurso Especial n. 797.668 - Paraíba, Rel Min. Humberto Gomes de Barros, j. 12.02.2008; STJ, Quarta Turma, Agravo Regimental no Agravo de Instrumento n. 909.383 - Rio de Janeiro, Rel Min. Fernando Gonçalves, j. 19.02.2008; STJ, Terceira Turma, Agravo Regimental no Agravo de Instrumento n. 976.667 - Distrito Federal, Rel Min. Massami Uyeda, j. 17.04.2008; STJ, Terceira Turma, Agravo Regimental no Agravo de Instrumento n. 988.475 Minas Gerais, Rel. Min. Massami Uyeda, j. 06.05.2008; STJ, Terceira Turma, Agravo Regimental no Agravo de Instrumento n. 989.921 - São Paulo, Rel. Min. Massami Uyeda, j. 21.08.2008; STJ, Segunda Turma, Agravo Regimental no Recurso Especial n. 1.037.329 - Rio de Janeiro, Rel. Min. Humberto Martins, j. 26.08.2008; STJ, Quarta Turma, Recurso Especial n. 931.360 - Maranhão, Rel. Min. Aldir Passarinho Junior, j. 02.09.2008; STJ, Terceira Turma, Agravo Regimental no Agravo de Instrumento n. 1.056.214 - Minas Gerais, Rel. Min. Sidnei Beneti, j. 18.11.2008 e STJ, Quarta Turma, Agravo Regimental nos Embargos de Declaração no Agravo de Instrumento n. 958.237 - Rio Grande do Sul, Rel. Min. Honildo Amaral de Mello Castro, j. 15.12.2009.

322 STJ, Terceira Turma, Recurso Especial n. 198.847 - Rio de Janeiro, Rel. Min. Waldemar Zveiter, j. 15.08.2000:

"Voto do Relator: (...)

Da pesquisa que realizei e dos precedentes acima, ressai o fato de que, na grande maioria dos precedentes, aquele que recebeu a citação era empregado ou gerente da empresa, e a citação havia sido feita em sua sede ou sucursal.

Embora tenha sempre me filiado a corrente mais liberal, acatando, com mais freqüência a teoria da apararência, não posso deixar de reconhecer que, no caso em apreço, a pessoa que recebeu a citação na notificação judicial, não era nem empregado, nem gerente, apenas contratado, como não nega a recorrente e nem as recorridads, para fazer vistorias em seu nome. 
Outro caso reconhece a polêmica em torno da validade da citação das pessoa jurídicas, mas no caso sob julgamento deixa de aplicar a "Teoria da Aparência" porque a citação fora realizada na pessoa de um procurador sem poderes específicos para recebê-la, o que deu azo à revelia da parte ré. Ocorre, porém, que no momento da execução da sentença condenatória, percenbendo infrutífera a diligência na pessoa do mesmo procurador, a parte autora indicou nos autos os legítimos representantes da citanda, sendo estes logo em seguida comunicados do curso do certame. Entendeu o tribunal que a parte autora não identificou oportunamente os representantes da pessoa jurídica e quis beneficiar-se da revelia que deliberadamente ocasionou ${ }^{323}$.

No terceiro julgado destacado, no qual restou vencido o Min. Ruy Rosado de Aguiar, que aplicava a "Teoria da Aparência" e validava o ato processual procedido na pessoa do gerente de uma filial da pessoa jurídica a ser citada ${ }^{324}$, prevaleceu a tese

Se as empresas seguradoras sabem que os armadores estrangeiros precisam de representantes legais no Brasil, antes de endereçarem a ação, precisam se certificar quem são, o que não se reveste da complexidade que procuram demonstrar, até porque, depois de tentativas frustradas de citação, informaram as demnadantes os dados corretos daquele, sem qualquer ressalva quanto a impossibildade de obtê-los anteriormente.

(...)

O certo é que esta Corte e em especial a Terceira Turma, tem sido rigorosa no acolhimento da tese defendida pelo acórdão recorrido e não encontro justificativa plausível, no caso em apreço, que possa justificar a citação na forma como foi procedida, porque feita em TERCEIRO. Ademais, até mesmo junto as suas seguradas poderiam ter as autoras buscado a informação correta sobre o representante legal da recorrente.

(...)"

323 STJ, Quarta Turma, Recurso Especial n. 275.921 - São Paulo, Rel. Min. Aldir Passarinho Junior, j. 07.11.2000:

"Voto do Relator: (...)

A matéria já foi objeto de muita polêmica, de um lado exigindo-se a rigorosa observância da efetiva representação social da empresa, consoante as normas estatutárias, e, de outro, uma maior flexibilização, atendendo-se ao princípio da celeridade processual e em face de conhecidas manobras para o retardamento da concretização do ato citatório, prejudicando a prestação jurisdicional

(...)

A citação é o ato mais importante em um processo, pois é ela que instaura a relação jurídico-litigiosa, dá o contorno da discussão e permite à parte adversa defender-se das alegações que lhe são imputadas. Daí porque não se pode prestigiar comportamento de duvidosa legitimidade do autor, como a de indicar para citação procurador sem serem conhecidos ao certo seus poderes, quando possível, como demonstrado, a identificação dos efetivos representantes legais que respondem pela empresa $e$ em nome de quem devia a citação ser realizada.

Registre-se que após o aditamento do mandado de citação e penhora, a diligência foi procedida sem entraves, e citados corretamente os representantes legias (...)

Destarte, pelas peculiaridades do caso, tenho que o aresto violou o art. 215 do CPC, certo que o procurador não detinha poderes para receber a citação, e que o autor, deliberadamente, deixou de apontar precisamente os representantes legias, criando revelia artificial, quando possível e fácil a identificação dos reais responsáveis pela empresa.

(...)"

324 STJ, Segunda Seção, Embargos de Divergência em Recurso Especial n. 147.206 - Paraná, Rel. p/ acórdão Min. Carlos Alberto Menezes Direito, j. 0811.2000:

"Voto Vencido:

(...) 
contrária segunda a qual, na realidade, o apontado gerente da filial da citanda induziu o Oficial de Justiça a erro, fazendo-o crer tratar-se de um legítimo representante da sociedade ${ }^{325}$.

Mais recentemente, foi também afastada a incidência da "Teoria da Aparência" em caso que a citação recaiu na pessoa de uma empregada da pessoa jurídica, cujo ofício nenhuma pertinência guardava com a recepção do ato processual, além da parte autora ao invés de indicar o endereço da sede da citanda, que constava do instrumento contratual objeto da contenda, optou por indicar o local da filial ${ }^{326}$. O mesmo entendimento prevaleceu no julgamento que tratou da citação de uma pessoa jurídica estrangeira realizada na sede da empresa pertencente ao mesmo grupo no Brasil, fixando o tribunal que a "Teoria da Aparência" não serve para justificar a citação de uma empresa por outra, uma vez que as pessoas jurídicas no caso analisado não se confundiam ${ }^{327}$.

O entendimento expresso nos precedentes contraria o aceito no r. acórdão que julgou nula a citação efetuada na pessoa do gerente, preposto da ré que não era seu representante legal. Ocorre que a citação podia ser validamente feita, nas circunstâncias dos autos, na pessoa de quem, sendo gerente da filial, não detinha poderes expressos de representação. Isso atendendo à teoria da aparência, consagrada nos paradigmas, como também à própria evolução do nosso direito processual, que recentemente alterou a legislação para passar a admitir a citação pelo correio na pessoa do gerente geral ou administrador, conforme consta doart. 223, par. único do CPC: 'Sendo o réu pessoa jurídica, será válida a entrega a pessoa com poderes de gerência geral ou de administração'. (...)”.

325 STJ, Segunda Seção, Embargos de Divergência em Recurso Especial n. 147.206 - Paraná, Rel. p/ acórdão Min. Carlos Alberto Menezes Direito, j. 0811.2000:

"Voto Condutor:

(...)

O voto do Senhor Ministro Ari Pargendler deixou claro que o Juiz afirmou exatamente o contrário; ou seja, o Juiz afirmou que o gerente da filial induziu o servidor da Justiça à crença de que tratava com alguém que representava a sociedade. Portanto, neste caso, o Acórdão recorrido não afirmou que se tratava de pessoa com poderes de representação.

Essas razões, Senhor Presidente, sempre louvando o voto lúcido do eminente Ministro Ruy Rosado de Aguiar, levam-me a dele discordar para, conhecendo dos embargos de divergência, rejeitá-los".

326 STJ, Quinta Turma, Recurso Especial n. 622.026 - São Paulo, Rel. Min. Arnaldo Estves Lima, j. 12.09.1006:

"Ementa: PROCESSUAL CIVIL. LOCAÇÃO. CITAÇÃO. NULIDADE. TEORIA DA APARÊNCIA. INAPLICABILIDADE. DISSÍDIO JURISPRUDENCIAL NÃO COMPROVADO. RECURSO ESPECIAL CONHECIDO E IMPROVIDO.

1. A citação constitui ato essencial para a formação do processo, e eventual inobservância na sua concretização implica violação ao princípio do contraditório. Daí o Poder Judiciário cercar-se de muita cautela na adoção da teoria da aparência.

2. Hipótese em que não se aplica a teoria da aparência, tendo em vista que a citação realizada na pessoa de uma empregada da empresa recorrida refere-se à uma ação de despejo por falta de pagamento, que não caracteriza uma operação normal de sua atividade. Ademais, a recorrente, não obstante tivesse conhecimento do endereço da sede da recorrida - expressamente indicado no contrato de locação entre elas celebrado -, apontou como endereço para a citação o do imóvel locado, onde funciona sua filial.

3. Dissídio jurisprudencial não comprovado.

4. Recurso especial conhecido e improvido".

327 STJ, Terceira Turma, Recurso Especial n. 993.235 - São Paulo, Rel. Min. Humberto Gomes de Barros, j. 13.11.2007: 
c) Conglomerado Financeiro - Cadernetas de Poupança

O Superior Tribunal de Justiça também sedimentou jurisprudência no tocante à incidência da "Teoria da Aparência" no âmbito das discussões da legitimidade ad causam das instituições financeiras para responder pela correção dos saldos das cadernetas de poupança em razão das diferenças de índices aplicados por ocasião dos planos econômicos de estabilização da moeda no Brasil.

No julgado cujos fundamentos alicerçaram diversas outras decisões posteriores ${ }^{328}$, a institução financeira alegou ilegitimidade para figurar no pólo passivo da demanda em que

\footnotetext{
"Voto do Relator:

(...)

A empresa ré (...) detém a maior parte do capital social de (...).

Nem por isso, entretanto, se confunde a sociedade italiana com a sociedade brasileira.

A ré - disso não há dúvidas - era a sociedade italiana. A citação - também não há dúvidas - foi recebida por funcionária da sociedade brasileira. Esta última - registre-se - não integrava a lide.

Para justificar tal procedimento, o Tribunal bandeirante invocou aparência. Sustentou que o oficial de justiça responsável pela citação certificou que a funcionária que recebeu o mandado não se recusou a assiná-lo nem negou ter poderes a tanto.

Ao assim fazer, equivocou-se o Tribunal local. Explico.

A invocação da aparência pode conferir eficácia às citações realizadas em pessoas diversas daquelas indicadas nos estatutos sociais das empresas. Com esse artifício, foram lançadas abaixo alegações infundadas de nulidade da citação.

Isso não significa, entretanto, que uma empresa possa ser citada por outra com base na teoria da aprência.
}

As sociedades brasileira e italiana não se confundem. Aquela não detém poderes de representação legal desta última.

(...)".

No julgado STJ, Terceira Turma, Recurso Especial n. 257.301 - Minas Gerais, Rel. Min. Waldemar Zveiter, j. 13.02.2001, o tribunal, curiosamente, invalidou a citação realizada por meio de Oficial de Justiça, visto que dirigida a pessoa física que nem sequer era empregada da pessoa jurídica e atestou a validade da citação via postal, entendendo que nesta hipótese a lei não exige poderes de representação, mas tão somente que a pessoa física exerça função de gerência geral ou de administração:

"Voto do Relator: (...)

Da pesquisa que realizei e dos precedentes acima, ressai o fato de que, na grande maioria dos precedentes, aquele que recebeu a citação era empregado ou gerente da empresa, e a citação havia sido feita em sua sede ou sucursal.

Embora tenha sempre me filiado a corrente mais liberal, acatando, com mais freqüência a teoria da apararência, não posso deixar de reconhecer que, no caso em apreço, e em relação a (...), a pessoa que recebeu a citação e assinou a notificação judicial, não era nem empregado, nem gerente, e nem o ato processual foi feito em sua sede ou filial.

O certo é que esta Corte e em especial a Terceira Turma tem sido rigorosa no acolhimento da tese defendida pelo acórdão recorrido e não encontro justificativa plausível, no caso em apreço, que possa justificar a citação na forma como foi procedida, porque feita em TERCEIRO.

(...)

Pela própria concepção e finalidade para a qual foi criada, a citação por via postal comporta uma elasticidade maior quanto a aceitação da Teoria da Aparência, sob pena de inviabilizar-se totalmente. Não tem exigido este STJ que aquele que recebe correspondência tenha poderes de representação, bastando que seja a carta citatória entregue no domicílio da ré e a seu empregado 'prescindindo esse que tenha poderes de gerrência ou administração' (...)”.

328 STJ, Terceira Turma, Recurso Especial n. 5.308 - Rio Grande do Sul, Rel. Min. Dias Trindade, j. 16.04.1991: 
seu cliente pleiteava diferenças de correção ao argumento de que a atividade de captação de poupança era efetuada por outra pessoa jurídica do seu conglomerado, mas não pelo próprio banco demandado.

O tribunal rechaçou a alegação invocando a "Teoria da Aparência", uma vez que a captação, embora contabilmente restasse a cargo de outra pessoa jurídica do conglomerado, era, na realidade efetuada pelo banco em suas agências espalhadas por todo o país, com uso de seu pessoal e mediante forte e farta propaganda de oferta dos mais variados serviços, inclusive a capatação da poupança popular ${ }^{329}$.

"Ementa: CIVIL/PROCESSUAL. LEGITIMIDADE PARA A CAUSA. PLANO BRESSER. CADERNETA DE POUPANÇA. SEGURO INFLAÇÃO.

(...)

2) TEM LEGITIMIDADE PARA FIGURAR NO POLO PASSIVO DA DEMANDA A INSTITUIÇÃO FINANCEIRA, QUE SE APRESENTA COMO CABEÇA DE ORGANIZAÇÃO COM ATIVIDADES MULTIPLAS, QUANDO A LIDE DIZ RESPEITO A CAPTAÇÃO DE POUPANÇA, QUE SE FAZ EM ESTABELECIMENTO DESSA MESMA INSTITUIÇÃO, COM A UTILIZAÇÃO DE SUA ESTRUTURA FUNCIONAL, AINDA QUE, ESCRITURALMENTE, EM NOME DE EMPRESA ESPECIFICA DO MESMO. (...)".

E no mesmo sentido: STJ, Terceira Turma, Recurso Especial n. 31.589 - Minas Gerias, Rel. Min. Dias Trindade, j. 08.03.1993; STJ, Terceira Turma, Recurso Especial n. 67.610 - Rio Grande do Sul, Rel. Min. Nilson Naves, j. 28.11.1995; STJ, Quarta Turma, Recurso Especial n. 83.746 - Minas Gerais, Rel. Min. Ruy Rosado de Aguiar, j. 11.03.1996; STJ, Quarta Turma, Recurso Especial n. 86.296 - Rio Grande do Sul, Rel. Min. Fontes de Alencar, j. 27.05.1996; STJ, Terceira Turma, Agravo Regimental no Agravo de Instrumento n. 102.800 - Rio Grande do Sul, Rel. Min. Waldemar Zveiter, j. 26.06.1996; STJ, Terceira Turma, Recurso Especial n. 61.956 - Rio Grande do Sul, Rel. Min. Nilson Naves, j. 17.09.1996; STJ, Terceira Turma, Recurso Especial n. 101.948 - Rio Grande do Sul, Rel. Min. Carlos Alberto Menezes Direito, j. 12.12.1996; STJ, Terceira Turma, Recurso Especial n. 113.929 - Rio Grande do Sul, Rel Min. Eduardo Ribeiro, j. 28.04.1997; STJ, Quarta Turma, Recurso Especial n. 145.258 - São Paulo, Rel. Min. Sálvio de Figueiredo Teixeira, j. 21.10.1997; STJ, Quarta Turma, Recurso Especial n. 155.944 - São Paulo, Rel. Min. Sálvio de Figueiredo Teixeira, j. 05.02.1998; STJ, Terceira Turma, Recurso Especial n. 151.375 - São Paulo, Rel Min. Eduardo Ribeiro, j. 03.03.1998 e STJ, Terceira Turma, Recurso Especial n. 163.429 - São Paulo, Rel. Min. Eduardo Ribeiro, j. 28.04.1998.

329 STJ, Terceira Turma, Recurso Especial n. 5.308 - Rio Grande do Sul, Rel. Min. Dias Trindade, j. 16.04.1991:

"Voto do Relator:

(...)

Embora entenda que legitimada para a ação é a parte que figura na relação de direito material, que suportará os efeitos da sentença, contudo, no caso em exame, a preliminar veio a ser argüida após as razões de apelação e sem que demonstrasse a ora recorrente, de qualquer modo, que envolvida na relação de direito material, no que diz com a captação de depósitos em cadernetas de poupança, seria outra empresa que não a própria ré e aqui recorrente.

Ora, a argüição se apresenta, deste modo, solteira de suporte fático, como destacou o acórdão recorrido, que teve a recorrente como legitimada para ação, ante a aparência com que se lança ao mercado, com utilização de farta propaganda, a induzir a prestação de serviços diversos, inclusive o de captação de poupança, sem a individuação do ente particular que nesse setor opera, até porque o faz. em estabelecimento único nas cidades do interior do país, com a utilização de estrutura e corpo de empregados únicos.

(...)

E é de levar em linha de consideração, na espécie em exame, que dos papéis com que os autores instruíram sua ação, consta como tendo atuado nessa captação o próprio Banco (...), não tendo, para o fim aqui perseguido, relevo que, escrituralmente, os valores captados e os rendimentos creditados se 


\section{d) Conglomerado Financeiro - Revisão de Cláusulas Contratuais}

Trata-se de caso concreto muito parecido, também envolvendo uma instituição financeira que alegou sua ilegitimidade para a causa, uma vez que os contratos objeto do pedido de revisão de cláusulas teria sido celebrado com outra pessoa jurídica integrante do seu conglomerado financeiro ${ }^{330}$. Da mesma forma, o tribunal aplicou a "Teoria da Aparência", que valoriza a situação fática em detrimento do estado jurídico em homenagem à boa-fé contratual, para fixar a reponsabilidade da empresa líder do conglomerado em estar no pólo passivo da demanda, uma vez que na visão do consumidor trata-se de um só ente, com o qual, por comodidade e relação de fidúcia, contrata os mais diversos serviços ${ }^{331}$.

efetivem em nome de outra empresa do grupo econômico, que se apresentam como um todo, em sua caracterização de banco múltiplo, tão utilizado nos negócios que empreendem.

(...)".

330 STJ, Terceira Turma, Recurso Especial n. 879.113 - Distrito Federal, Rel. Min. Nancy Adrighi, j. 01.09.2009:

"Voto da Relatora: Cinge-se a controvérsia em defenir se uma empresa, líder de conglomerado financeiro, detém legitimidade passiva para figurar no pólo de ação de revisão de cláusula de contratos de mútuos feneratícios, entabulado entre o recorrente e uma das empresas componentes do grupo financeiro liderado pelo banco recorrido".

331 STJ, Terceira Turma, Recurso Especial n. 879.113 - Distrito Federal, Rel. Min. Nancy Adrighi, j. 01.09.2009:

"Voto da Relatora: É certo que nada impede que um conglomerado financeiro, composto de várias pessoas jurídicas, opere em conjunto, com a oferta de serviços e produtos ao público em geral, situação que inclusive, não raras vezes reflete em comodidade para o próprio consumidor, que tem, à sua disposição, inúmeros serviços e conveniências que de outro modo, demandariam deslocamentos $e$ repetidas exigências burocr'ticas.

Igualmente infastável, porém, é a conclusão de que a situção acima descrita, induz o consumidor a pensar que está a contratar com uma única pessoa jurídica - o banco líder do conglomerado. Tanto assim, que o faz nas instalações do banco, utiliza-se do cadastro pré-existente e de possíveis prerrogativas que detém como correntista.

A situação descrita perfaz verdadeira intermediação do banco-recorrido na consumação dos contratos estabelecidos em sua agência, não apenas por dar suporte físico para s operações - instalações e pessoal -, mas, principalmente, a referendar, perante o consumidor, a transação financeira, vale dizer, avalizar e estimular a realização do contrato com fatores imateriais: como a sua solidez, a existência de prévio relacionamento comercial com o consumidor, ou ainda, por meio da publicidade do conglomerado.

Assim, embora do ponto de vista técnico-jurídico a instituição contratante - (...) - e o banco-recorrido, sejam pessoas jurídicas diversas, na visão dos consumidores que realizam diversas operações financeiras no mesmo local - agência do banco recorido -, existe apenas uma instituição financeira com a qual celebram todos os contratos.

Sob esse prisma, inafastável é apreciação da questão à luz dos princípios que regem as relações de consumo, notadamente a Teoria da Aparência, traduação aplicada da boa-fé contratual, pela qual se busca valorizar o estado de fato e o reconhecimento das circunstâncias efetivamente presentes na relação contratual.

(...)

Assim, impõe-se a conclusão de que a proposital manutenção de imagem una acarreta para o conglomerado financeiro, principalemtne na figura de sua empresa líder, o ônus de responder, no pólo passivo, às ações onde consumidores pleiteiem a revisão de contratos firmados com qualquer empresa componente deste conglomerado. 
e) Conglomerado Financeiro - Contrato de Seguro

Novamente aparecem em contenda as instituições financeiras, desta feita alegando sua ilegitimidade ad causam para responderem pelas ações propostas por seus clientes com escopo de discutir contratos de seguros firmados em suas agências, mas com companhias seguradoras pertencentes aos conglomerados financeiros. $\mathrm{Na}$ mesma linha de entendimento, o Superior Tribunal de Justiça espancou a alegação dos bancos ao argumento de na qualidade de empresas líderes de seus respectivos conglomerados e beneficiários econômicos dos variados serviços que prestam, inclusive por meio de sociedades subsidiárias, as instituições financeiras incutem no consumidor a idéia de que suas diversas empresas são uma coisa só, até mesmo porque aos clientes é facultada diversificada gama de serviços e produtos no mesmo local - a agência bancária - e pelos mesmos funcionários ${ }^{332}$.

(...)

Desta forma, aplica-se, à espécie, a Teoria da Aparência, em face dos princípios da boa-fé, da garantia de ampla defesa do consumidor, consubstanciada na facilitação de sua atuação em Juízo, razões pelas quais, impõe-se o reconhecimento da legitimidade passiva do banco recorrente.

(...)".

332 STJ, Quarta Turma, Recurso Especial n. 331.465 - Rondônia, Rel. Min. Ruy Rosado de Aguiar, j. 06.12.2001:

"Voto do Relator:

(...)

2. O contrato de seguro em grupo foi celebrado com a Companhia Seguradora (...), cujo presidente é nomeado pelo Banco (...); foi intermediado pela (...), companhia integrante do mesmo grupo econômico do Banco (...); a estipulante é entidade associativa dos empregados do Banco (...); o pagamento do prêmio se dava mediante lançamento em conta corrente na agência do Banco (...); o certificado deveria ser entregue na agência do Banco (...) e todas as informações e comunicações, feitas diretamente à mesma agência do Banco (...).

Diante desses fatos, assim reconhecidos e demonstrados nos autos, é de se concluir que o contrato de seguro é uma operação que interessa ao grupo liderado pelo Banco (...), e a ação pode ser proposta contra qualquer uma das entidades que participam do negócio, ora intermediando, ora segurando, ora usando de sua logomarca, do seu prestígio e de suas instalações, quando não de seus empregados, para celebração do contrato de seguro.

(...)

Disso tudo se conclui que o segurado ou o seu beneficiário (que confiam na aparência do negócio e na responsabilidade daquele com quem mais diretamente contratou, e muitas vezes não têm condições de perceber, no complexo empresarial, qual a entidade que realmente the deve o pagamento da indenização que têm direito) podem dirigir a ação contra qualquer um dos participantes do negócio securitário, quando ele surge envolvido com a atuação da entidade bancária, líder do grupo, que usa de suas instalações, de seus agentes, de suas empresas e das oportunidades de negócio que a sua atividade principal lhe propicia, para celebrar contratos de seguro. Assim é que tem sido admitida a legitimidade passiva da empresa líder, da que atua como estipulante e da sua corretora de seguros.

(...)"

Outro caso idêntico, envolvendo o mesmo conglomerado financeiro, é o STJ, Quarta Turma, Recurso Especial n. 332.787 - Goiás, Rel. Min. Ruy Rosado de Aguiar, j. 11.12.2001:

"Voto do Relator:

(...)

2. Trata-se de uma operação 'casada', em que o Banco exige do cliente a celebração de contrato de seguro, convencionado com entidade ligada ao mesmo grupo, nas instalações da agência bancária e 


\section{f) Consórcio}

Neste caso tratou o Superior Tribunal de Justiça de julgar a legitimidade passiva de empresa que embora não administrasse o Grupo de Consórcio objeto da controvérsia, permitiu o uso de sua marca, de seu endereço e telefones, de seus vendedores, além da farta publicidade com o seu nome, tudo de modo a levar a crerem os consorciados que com ela contrataram. A empresa realmente responsável pelo consórcio, por seu turno, teve

pelos funcionários do banco. À vantagem do contrato bancário, ainda se soma a da operação securitária, com acréscimo na produção e lucro do grupo, e o aumento da renda do bancário, modo de remunerar. Nessas condições, não parece suficiente dizer que o Banco foi um mero corretor de seguro, senão que é a entidade que surge à vista do cliente como sendo aquele com quem foi contratado o financiamento e o seguro. Logo, na realação de consumo que assim se estabelece, a ação pode ser dirigida diretamente contra a instituição bancária, que a final é a interessada econômica na operação, tanto assim que foi a única que contestou, e se defendeu não apenas quanto à ilegitimidade, mas discorreu a respeito da própria questão de fundo. Na verdade, o Banco atuaou antes e agora como sendo o real contratante.

(...)"

E ainda no mesmo sentido: STJ, Terceira Turma, Recurso Especial n. 56.199 - Goiás, Rel. Min. Waldemar Zveiter, j. 14.08.1995; STJ, Quarta Turma, Recurso Especial n. 67.237-6 - Minas Gerais, Rel. Min. Fontes de Alencar, j. 10.03.1997; STJ, Quarta Turma, Recurso Especial n. 255.637 - Paraíba, Rel. Min. César Asfor Rocha, j. 26.06.2001 e STJ, Terceira Turma, Recurso Especial n. 434.865 Rondônia, Rel. Min. Castro Filho, j. 13.09.2005.

No julgamento do Recurso Especial n. 641.483 - Rio Grande do Sul (STJ, Terceira Turma, Rel. Min. Carlos Alberto Menezes Direito, j. 20.10.2005), o tribunal, por falta de prequestionamento da matéria, deixou de analisar a incidência da "Teoria da Aparência" aplicada pelo juízo a quo, prevalencendo desse modo o acórdão recorrido, do Tribunal Regional Federal da $4^{\text {a }}$ Região, que justamente responsabilizava uma instituição financeira líder de um conglomerado para figurar no pólo passivo de ação judicial em que se discutia um contrato de seguro residencial celebrado na agência do banco demandado.

Já no Agravo Regimental no Recurso Especial n. 969.071 - Minas Gerais (STJ, Terceira Turma, Rel. Min. Sidnei Beneti, j. 12.08.2008), a Corte Superior em razão da barreira fixada na sua Súmula 07 deixou prevalecer o acórdão recorrido, do Tribunal de Justiça do Estado de Minas Gerais, que afastou a incidência da "Teoria da Aparência" também em discussão envolvendo contrato de seguro firmado em agência bancária, ao argumento de que o conjunto probatório demonstrou no caso que apesar de pertencerem ao mesmo conglomerado financeiro, as as pessoas jurídicas mantinham sua individualidade:

"Ementa: AGRAVO REGIMENTAL. AÇÃO DE EXECUÇÃO. CONTRATO DE SEGURO DE VIDA E ACIDENTES PESSOAIS. OMISSÃO DO ACÓRDÃO RECORRIDO. INEXISTENNCIA. PECULIARIDADES DO CASO QUE NÃO AUTORIZAM A LEGITIMIDADE PASSIVA DA INSTITUIÇÃO FINANCEIRA PERTENCENTE AO MESMO GRUPO ECONÔMICO DA SEGURADORA. REEXAME DE PROVA. SÚMULA 7/STJ.

(...)

II - A jurisprudência desta Corte tem reconhecido a legitimidade da instituição financeira para responder pelo cumprimento de contrato de seguro nas hipóteses em que o banco, líder do grupo econômico a que pertence a companhia seguradora, se utiliza de suas instalações, logomarca, prestígio, empregados, induzindo o consumidor a crer que, de fato, está contratando com a instituição bancária, entendimento que decorre da aplicação da teoria da aparência.

III - Na hipótese em exame, contudo, sopesando as circunstâncias fáticas da causa, asseverou o Tribunal de origem não haver dúvida de que a recorrente contratou a apólice diretamente com a empresa seguradora, não sendo a instituição financeira, por esse motivo, parte legítima para responder à ação de execução fundada no contrato firmado entre as partes.

III - As premissas fáticas que conduziram o Colegiado estadual a esse entendimento não podem ser revistas em âmbito de recurso especial, a teor do enunciado 7 da Súmula desta Corte.

Agravo improvido". 
decretada a sua liquidação extrajudical pelo Banco Central do Brasil, de modo que restou aos seus clientes buscar a responsabilização daquela empresa com a qual "aparentemente" teriam celebrado o negócio jurídico ${ }^{333}$.

Em julgado mais recente, também versando sobre a legitimidade passiva para responder ação judicial tendo como objeto contrato de consórcio, vencido o Min. Relator Luis Felipe Salomão ${ }^{334}$, o tribunal entendeu por afastar a incidência da "Teoria da

333 STJ, Quarta Turma, Recurso Especial n. 113.012 - Minas Gerais, Rel. Min. Ruy Rosado de Aguiar, j. 18.03.1997:

"Voto do Relator:

(...)

Trata-se de estabelecer a presença das condições da ação, especialmente da legitimidade passiva da ré.

Para isso, devo levar em consideração o pedido da autora, assim como exposto na sua inicial. Pretende ela ser indenizada pelos prejuízos que sofreu com o descumprimento do contrato de consórcio para aquisição de um automóvel que ela acreditava ter firmado com a empresa (...). E enumera as circunstâncias que a levaram a assim pensar: o consórcio denominava-se (...); a sede era no endereço da empresa (...); o logotipo (...), usado no consórcio, é o da empresa (...); os telefones são os mesmos; a publicidade feita destacava apenas a logomarca (...); os vendedores apresentavam cartões da (...); os veículos dos consorciados eram entregues pela (...); a empresa administradora do consórcio e a (...) pertencem a membros de um mesmo núcleo familiar.

(...)

Assim posta a causa, ela somente poderia ser mesmo dirigida contra a (...), pois é dela que a autora pretende receber a indenização pelo dano sofrido por confiar na situação que a empresa ré permitiu fosse criada em torno do empreendimento, fato relevante não apenas para o interesse individual da reclamante, mas também à sociedade de consumo e à economia popular.

A autora quer ver reconhecida a responsabilidade de quem fez a publicidade, nos termos do art. 30 do CODECON, e extrair dali as conseqüências necessárias. Não afiirma ser a ré a administradora do consórcio, apenas lhe atribuiu ter permitido fossem criadas as condições para que os outros confiassem no empreendimento, que aparecia como sendo seu, ou pelo menos de sua responsabilidade, explorando a credibilidade e a confiança que obteve no mercado. É como se nos consórcios que hoje são feitos em nome de grandes empresas fabricantes, como por exemplo o consórcio GM, pudesse esta escusar-se de qualquer responsabilidade, atribuindo-a a uma outra pessoa jurídica, desconhecida e sem qualquer idoneidade no mercado. A defesa poderia sere apresentada, mas não é legítima e fere a boa-fé.

(...)".

No mesmo sentido: STJ, Quarta Turma, Recurso Especial n. 139.400 - Minas Gerais, Rel. Min. Cesar Asfor Rocha, j. 03.08.2000:

"Ementa: PROCESSUAL CIVIL. CONSÓRCIO. TEORIA DA APARÊNCIA. LEGITIMIDADE PASSIVA RECONHECIDA.

A empresa que, segundo se alegou na inicial, permite a utilização da sua logomarca, de seu endereço, instalações e telefones, fazendo crer, através da publicidade e da prática comercial, que era responsável pelo empreendimento consorcial, é parte passiva legítima para responder pela ação indenizatória proposta pelo consorciado fundamentada nesses fatos. Recurso conhecido e provido".

334 STJ, Quarta Turma, Recurso Especial n. 566.735 - Paraná, Rel. p/ acórdão Min. Fernando Gonçalves, j. 10.11.2009:

"Voto Vencido:

(...)

A questão, portanto, é saber se a concessão para a venda de veículos, com a utilização da marca e garantia da montadora, implica sua responsabilidade pelos atos praticados pela concessionária, sobretudo aqueles relacionados diretamente com a venda de automóveis.

(...)

Assim, com a assinatura do contrato de concessão, a fabricante assume os bônus e os ônus da utilização de sua marca, e é exatamente por esta que o consumidor sente-se atraído, sendo desimportante, na generalidade das vezes, dirigir-se a esta ou àquela concessionária. 
Aparência" sob o argumento de que o acórdão hostilizado deixou claro que os consorciados teriam celebrado os contratos tão somente com a concessionária, sem intervenção da fabricante concedente e rediscutir tal assertiva esbarra na vedação ao revolvimento de provas em sede excepcional ${ }^{335}$.

(...)

Realmente, sob a ótica do consumidor, a concessionária, em qualquer negócio jurídico por ela celebrado, ao estampar determinada marca, apresenta-se sempre como uma parceira da fabricante, esta sim, em quem o usuário deposita sua confiança em razão da marca consolidada no mercado automobilístico.

Ao celebrar um contrato de compra e venda, o consumidor crê, deveras, que o está a celebrar com a montadora, e apenas de forma intermediária o faz com a concessionária. Essa aparência de garantia, com a qual concorreu a montadora ao fornecer sua marca, em nome do princípio da boa-fé, deve ser tutelada pelo direito.

(...)

Por isso que não poderia mesmo o consumidor sequer supor que o contrato celebrado, que levava a marca (...), não era do seu conhecimento ou por ela garantido. Na verdade, a utilização de marca de renome - utilização essa, repito, consentida, até por força da Lei (art. $3^{\circ}$, inciso III, da Lei $n^{\circ}$ 6.729/79) - gerou ao consumidor legítima expectativa de que o consórcio era garantido pela fornecedora, razão pela qual deve esta ressarcir os recorrentes pelos danos por eles sofridos.

(...)

Não é aceitável, sob qualquer ângulo, que a concedente quede-se inerte quando as práticas comerciais da concessionária - a despeito de falta de autorização - sejam-lhe economicamente proveitosas, $e$, futuramente, insurja-se contra estas mesmas práticas, quando interpelada a ressarcir danso causados a terceiros. É da própria lógica emergente do CDC não poder o fornecedor livrar-se de ressarcir os danos causados por práticas comerciais realizadas por concessionária credenciada, em decorrência das quais também auferiu algum lucro.

(...)".

335 STJ, Quarta Turma, Recurso Especial n. 566.735 - Paraná, Rel. p/ acórdão Min. Fernando Gonçalves, j. 10.11.2009:

"Voto Condutor:

(...)

A questão central da demanda cinge-se em definir se há responsabilidade da montadora pelos atos praticados pela concessionária, que faz uso, em suas atividades comerciais, da marca e garantia da concedente.

(...)

De outro lado, não há espaço, in casu, para a aplicação da teoria da aparência, cujo escopo é a preservação da boa-fé nas relações negociais, afastando-se o óbice de pactuação com terceiro.

Isto porque, consoante assevera o acórdão recorrido, 'os contratos firmados pelas apelantes eram claros, sendo que as partes envolvidads eram tão somente a concessionária (...) e o adquirente, sem qualquer intervenção da concedente (...).

Não há razão que se falar, neste contexto, em tutela da aparência pelo simples fato da utilização, nos contratos celebrados, da marca da recorrida, praxe comercial amplamente difundida e incapaz de, por si só, ocasionar confusão ao consumidor.

Não se pode, pois, dar ensejo à responsabilização solidária da fabricante pelas práticas comerciais independentes e não subordinadas - da concessionária.

(...)

Neste contexto, para que se adote conclusão em sentido contrário, é necessária a interpretação de cláusulas dos contratos firmados entre as partes, assim como o reexame das provas constantes dos autos, a fim de que se alterem as premissas fáticas fixadas nas instâncias ordinárias, fortes no sentido da falta de anuência da concedente em relação ao consórcio levado a efeito pela revendedora. Estas providências, porém, restam vedadas em sede especial, a teor das súmulas 05 e 07 do Superior Tribunal de Justiça.

(...)". 
g) Títulos de Crédito

Nos casos envolvendo discussão acerca emissão, endosso e aval de da Títulos de Crédito o Superior Tribunal de Justiça afastou a "Teoria da Aparência" de forma a privilegiar as formalidades inerentes a estes instrumentos de circulação do crédito.

São exemplos os julgados versando sobre a validade do aval aposto em Nota Promissória por filho do avalista dizendo-se mandatário do pai, porém sem poderes especiais para a prática do ato cambial ${ }^{336}$. O tribunal afastou a "Aparência de Direito" justamente sob o argumento de que os atos jurídicos cambiais exigem poderes específicos e não contentam-se com a fórmula geral do art. 1.295 do velho Código Civil $^{337}$ que credenciam o mandatário tão somente para a prática dos poderes gerais e ordinários de administração dos negócios do mandante. Além do mais, consignou que o aval é ato personlíssimo, exigindo solenidades essenciais para a sua efetivação, daí encontrando anteparo a incidência da "Teoria da Aparência" e brotando o dever da instituição financeira, cuja atividade guarda absoluta petinência temática com o caso, de conferir os poderes daquele que alega estar credenciado para a prática do ato cambial e não o exsurge a sua reponsabilidade por aceitar o aval irregularmanete aposto na Nota Promissória ${ }^{338}$.

336 STJ, Quarta Turma, Recurso Esepecial n. 50.841-0 - Rio de Janeiro, Rel. Min. Ruy Rosado de Aguiar, j. 09.08.1994:

"Ementa: NOTA PROMISSORIA. AVALISTA. MANDATARIO. A VALIDADE DO AVAL ESTA CONDICIONADA A ASSINATURA DO PROPRIO PUNHO DO AVALISTA OU DO MANDATARIO ESPECIAL, ISTO E, DO QUE EXIBE MANDATO POR ESCRITO, COM PODERES EXPRESSOS PARA A PRATICA DE ATOS CAMBIAIS. O SIMPLES FATO DO FILHO DIZER-SE MANDATARIO DO PAI PARA, EM SEU NOME, ASSINAR COMO AVALISTA NOS TITULOS DE DIVIDA EM QUE ELE FILHO OU SUA EMPRESA FIGURAVAM COMO DEVEDORES PRINCIPAIS, NÃO BASTA PARA O RECONHECIMENTO DE QUE ESTAVA ASSUMINDO PELO OUTRO A RELAÇÃO CAMBIAL DO AVAL. CABIA AO CREDOR EXEQUENTE EXIGIR A PROCURAÇÃO, NO MOMENTO DO ATO, E, DEPOIS, QUANDO DA COBRANÇA, FAZER A PROVA DO MANDATO, COM BASE NO QUAL FORAM OS TITULOS ASSINADOS.

(...)"

337 Art. 1.295. O mandato em termos gerais só confere poderes de administração.

$\S 1^{\circ}$ Para alienar, hipotecar, transigir, ou praticar outros quaisquer atos, que exorbitem da administração ordinária, depende a procuração de poderes especiais e expressos.

338 STJ, Quarta Turma, Recurso Especial n. 278.650 - Paraná, Rel. Min. Aldir Passarinho Junior, j. 08.05.2001:

"Voto do Relator: Trata-se de recurso especial, aviado pelas letras 'a' e 'c' do permissor constitucional, contra acórdão que rejeitou embargos à execução, ao fundamento de que o aval concedido pelo filho da executada era válido, posto que o mesmo detinha mandato com poderes de gerência nos negócios, inclusive quanto à disponibilidade de bens.

(...)

De efeito, reconhece o aresto a quo que o mandato não previa poderes expressos para prestar aval, recorrendo, no entanto, à teoria da aparência.

Tenho que tal teoria deve ser aplicada restritivamente, e esta tem sido a minha orientação pessoal, sob pena de se abandonar solenidades essenciais, que longe de servirem apenas a solenidades 
Também se discutiu a validade de endosso aposto em cheque por quem não detinha poderes para tanto e o fez fraudulentamente em prejuízo da pessoa jurídica a que o título estava nominalmente endereçado e em benefício próprio ${ }^{339}$. Havia no âmbito do Superior Tribunal de Justiça dissonância de entendimentos no tocante à responsabilidade dos bancos em averiguar a regularidade da cadeia de endossos aposta no cheque, sendo pacífica somente a desnecessidade de conferência da autenticidade das assituras. A solução exarada no voto condutor do Min. Antônio de Pádua Ribeiro, a qual pacificou a jurisprudência da Corte Superior, foi no sentido de responsabilizar a instituição financeira pela verificação da regularidade do endosso, especialmente no tocante à necessidade de conferência de poderes expressos para realização do ato, inclusive, no caso concreto, com análise dos documentos societários da pessoa jurídica para a qual o cheque era nominal ${ }^{340}$.

burocráticas, visam, na verdade, emprestar fidelidade e segurança às relações jurídicas, atos procedimentais e processuais.

O aval é ato personalíssimo, posto que importa no comprometimento do patrimônio do garantidor, a ponto de levá-lo, em certas cirncunstâncias, à insolvência. Daí, inaceitável, tenho eu, admitir-se como válido aval dado por procurador que não possuía poderes específicos para tanto, mormente em se cuidando de um estabelecimento bancário, que não pode alegar desconhecimento das regras aplicáveis aos mútuos, por serem operações corriqueiras, inerentes a sua atividad social.

Assim, se indevidamente aceitou um aval nulo, nem por isso há de afastar as regras legais para contornar lapso do exeqüente, salientando-se que a execução se faz com base na nota promisória.

(...)".

339 STJ, Segunda Seção, Embargos de Divergência em Recurso Especial n. 280.285 - São Paulo, Rel. p/ acórdão Min. Antônio da Pádua Ribeiro, j. 25.06.2003:

"Relatório: Cuida-se de embargos de divergência em face de acórdão proferido pela $4^{a}$ Turma que proveu recurso esepcial para reconhecer a responsabilidade da instituição financeira pela verificação da regularidade da série de endossos, nos termos do art. 39 da Lei n. 7.357/85, em cheque de emissão de terceiro, nomial à empresa (...), que foi endossado irregularmanete por ex-gerente desta, em seu benefício e em detrimento da empresa autora".

340 STJ, Segunda Seção, Embargos de Divergência em Recurso Especial n. 280.285 - São Paulo, Rel. p/ acórdão Min. Antônio da Pádua Ribeiro, j. 25.06.2003:

"Voto Condutor:

(...)

O dissídio esta caracterizado. Sobre bases fáticas semelhantes - depósito de cheque nomial com endosso irregular - foram dadas soluções divergentes, ora pela responsabilidade do banco, ora pela ausência desta. $\mathrm{O}$ acórdão embargado entendeu que o banco, a despeito de não ter de analisar a autenticidade da assinatura dos endossos, deve averiguar se a pessoa que endossou em nome da pessoa jurídica tem poderes para representá-la, exigindo, por exemplo, cópia do contrato social da empresa. Em não o fazendo, responsabiliza-se pelos danos daí advindos.

Os julgados colacionados pelo embargante, a seu turno, encampam a tese de que a instituição financeira, além de não ter de examinar a autenticidade das assinaturas, não está obrigada a verificar a legitimidade do endossante para representar a pessoa jurídica beneficiária do cheque. O banco, portanto, não tem obrigação de indenizar.

(...)

Em verdade, tem-se que, no caso concreto, em momento algum se questionou a autenticidade da assinatura do endossante. Este, antigo funcionário do embargado, endossou o cheque nominal e o depositou em sua própria conta. O ponto é incontroverso, não houve falsificação de assinaturas, às quais, portanto, não se pode dizer faltar autenticidade.

Ocorre que o depositante não tinha legitimidade para endossar o cheque - nominal ao embargado - pois não se lhe havia conferido poderes para tanto. Ora, se ao banco embargante não cabia conferir se o 
Já sobre a aposição de aceite em Duplicata Mercantil por empregado de pessoa jurídica que não detinha poderes de (re)presentação, mas em face das circuntâncias fáticas de haver sido as mercadorias entregues na sede da empresa e recebida por seus empregados, dentre eles o seu "supervisor de vendas", à época dos fatos ainda no exercício das suas funções, o Superior Tribunal de Justiça acolheu a incidência da "Teoria da Aparência”, de modo a privilegiar a boa-fé da empresa que vendeu as mercadorias e encontrou óbice no adimplemento do preço $^{341}$.

depositante poderia endossar em nome do embargado, em que sentido, então, se diz que a instituição financeira deve conferir a regularidade dos endossos? (...)

A assinatura do endossante era autêntica, mas ele não tinha legitimidade para o endosso. E, conforme bem destacado no julgado embargado, a legitimidade do endossante é condição para regularidade dos endossos. (...)

Ocorre que o dever de verificar a regularidade dos endossos é imposição legal, ao passo que a análise da autenticidade das assinaturas é ônus que a lei não impôs à instituição financeira. E não impôs porque não possuindo o sacado - ou apresentante - 'a ficha de firma de quem não seja seu cliente, não pode verificar a autenticidade da assintura e, consequentemente, responder por eventual inautenticidade'. (...)".

341 STJ, Quarta Turma, Recurso Especial n. 135.306 - São Paulo, Rel. Min. Barros Monteiro, j. 07.10.2003:

"Voto do Relator:

Segundo a recorrente, não adquiriu ela o equipamento; tendo sido comprado o computador por (...), seu ex-supervisor de vendas, que nunca teve poderes para representá-la. Acentuou que a aparelhagem jamais ingressara em seu ativo, tanto que sequer chegou a ser escriturada a operação. Disse mais que os negócios jurídicos celebrados com a ré eram precedidos de pedidos de fornecimento, dos quais constava necessariamente a assinatura de seu representante legal, (...).

Tal é a versão apresentada pela recursante, que, entretanto, não coincide com os fatos da causa descritos pelo decisório recorrido. Em consonância com o assentado pelo Tribunal de origem, em sede de embargos infrigentes, não houvera, nas diversas transações entre as litigantes, uma uniformidade de procedimento por parte da ora recorrente nas suas solicitações de compra. Asseriu a Corte estadual ainda que (...) era funcionário da empresa autora, na qual exercia a função de 'supervisor de vendas', esclarecendo ainda que o equipamento fora recebido na sede da demandante, por empregados seus.

(...)

Embora a referida 'teoria da aparência' deva ser aplicável com prudência, tal como advertem precedentes da Casa, no caso, ela incide às inteiras, ante asituação de fato peculiar à hipótese sub judice, tal como registrada pelo Acórdão recorrido. Inexistindo, como asseverou a decisão combatida, procedimento uniforme da autora quanto à solicitação de compras, a entrega da mercadoria em sua sede, recebida por seus empregados, é o suficiente para caracterizar a operação de compra e venda mercantil por ela realizada. Basta assinalar que o mencionado (...) exercia ainda a função de 'supervisão de vendas' à época da concretização daquele negócio jurídico. Sua demissão aconteceu apenas dias depois, quando teria ele tomado destino ignorado.

Não se pode afastar, em outro mais, a boa-fé da empresa vendedora, princípio que o decisum recorrido preferiu prestigiar em oposição ao aspecto meramente formal defendido pela recorrente (empregado supervisor de vendas - desprovido de poderes de representação da pessoa jurídica).

(...)".

Em caso análogo, no STJ, Quarta Turma, Recurso Especial n. 668.682 - Minas Gerais, Rel. Min. Hélio Quaglia Barbosa, j. 13.02.2007, em que "debate-se, in casu, a posibilidade de oposição à recorrente, empresa de factoring e atual portadora dos títulos (dezenove duplicatas aceitas por funcionário da empresa recorrida), da inexistência de lastro negocial entre os contratantes originários, como restou comprovado nas instâncias ordinárias" o tribunal com espeque nas decisões recorridas também acolheu a "Teoria da Aparência" para privilegiar o princípio da abstração dos títulos de créditos e a sua inoponibilidade:

"Voto do Relator:

(...) 


\section{h) Credor Putativo}

Em outra posição prudente do Superior Tribunal de Justiça, foi afastada a "Teoria da Aparência" em julgado que discutiu a o dispositivo de valida a pagamento realizado ao "credor aparente" ou "credor putativo" do velho Código Civil ${ }^{342}$. No caso, uma determinada Municipalidade procedeu à compra de veículos de uma montadora por intermédio de sua concessionária, tudo mediante o regular procedimento administrativo. No momento de adimplir a obrigação, o que deveria ser feito na modalidade à vista, a Prefeitura Muncipal efetuou o pagamento para concessionária que já se encontrava em estado de insolvência, o que deu azo à ação judicial da montadora em perseguição ao seu crédito. $\mathrm{O}$ acórdão, no entanto, não encontrou na base fática levada a julgamento subsídio para reputar o escusável o erro do devedor e por conseguinte incidente a figura do pagamento realizado ao "credor putativos", visto que constava expresamente das notas fiscais supedâneo da pagamento realizado a advertência de que este ato deveria ser realizado contra a montadora, concluindo, desse modo, ser ilícito à Municipalidade escusar-se de novo pagamento ao verdeiro e legítimo credor ${ }^{343}$.

\footnotetext{
6. Contudo, no caso dos autos, em nenhum momento restou evidenciado qualquer comportamento irregular da recorrente, indicador de sua ciência do descumprimento do acordo realizado entre as partes originárias.

(...)

Ademais, houve o aceite dos títulos, por parte de funcionários da empresa recorrida, cuja ausência de poderes bastantes para tanto, como registrado na sentença primeira, não constituiu empecilho à validade do ato; verbis: '(...) Em relação aos aceites apostos às cártulas pelos ex-empregados (...) e (...), respectivamente Gerente de Setor e Gerente de Departamento de Bazar, tais subscrições não renderiam ensejo, por si só, à invalidação do negócio, vindo em socorro à embargada, neste tópico, a Teoria da Aparência neas relações mercantis, não lhe sendo exigível o prévio conhecimento dos Estatutos Sociais da empresa para averiguação dos poderes conferidos aos aceitantes da cártulas'.

5. Pelo exposto, tenho que a solução se encontra na reforma dos julgados precedentes, isso porque, ainda que a duplicata mercantil tenha por característica o vínculo à compra e venda mercantil ou prestação de serviços realizada, ocorrendo o aceite - como verificado nos autos -, desaparece a causalidade, passando o título a ostentar autonomia bastante para obrigar a recorrida ao pagamento da quantia devida, independentemente do negócio jurídico que lhe tenha dado causa.

(...)".

${ }^{342}$ Código Civil de 1916:

"Art. 935. O pagamento feito de boa-fé ao credor putativo é válido, ainda provando-se depois que não era credor".

343 STJ, Quarta Turma, Recurso Especial n. 2.584 - Espírito Santo, Rel. Min. Sálvio de Figueiredo Teixeira, j. 17.12.1991:

"Voto do Relator: Tem-se igualmente acentuado que o acolhimento da teoria da aparência se arrima na exigência da preservação da segurança das relações jurídicas e no resguardo da boa-fé de terceiros, (...). In casu, não descortino o concurso de circunstâncias que tornem escusável o erro do devedor.

Com efeito, se tudo estava a canalizar o entendimento autorizador da incidência da referida teoria, é de convir-se, como salientou o v. acórdão, que nas notas fiscais, nas quais se baseou o recorrente para efetuar o pagamento, em todas elas havia expressa advertência de que a quitação somente se daria contra recebimento de ordem de pagamento ou cheque nominal em favor da montadora (...), antecessora da recorrente-autora.
} 
O mesmo entendimento foi consignado em julgado que apreciou a validade de pagamento de alugueres realizado na pessoa do antigo proprietário do imóvel, quando ele já havia realizada a venda do bem, restando patente no conjunto probatório que os locatários tinham inequívoca ciência da transmissão da propriedade do objeto da locação ${ }^{344}$.

E em julgamento mais recente, da mesma maneira, o Superior Tribunal de Justiça também afastou a "Teoria da Aparência" no caso concreto em que uma seguradora pagou a indenização referente a apólice de seguro a pessoas diferentes da legítima beneficiária, ou seja, a duas filhas do segurado sendo que a beneficária era a esposa do falecido. A Corte Superior julgou que o erro da seguradora, dadas as circunstâncias fáticas, não era escusável, e que deveria haver melhor se detido sobre os documentos pertinentes que indicavam a real beneficiária da apólice de seguro, em nada mitigando esse dever o fato da beneficiária haver presenciado o pagamento às suas filhas, credoras putativas na visão da companhia de seguros $^{345}$.

Destarte, não era lícito ao recorrente ignorar tal ressalva, por mais bem intecionado que estivesse, em face de circunstância tão elementar, mesmo em se desprezando a observação do em. Desembargador Vogal, segundo a qual não se saberia dizer, naquela alatura, quem teria agido de má-fé, dado que a empresa concessionária e seu proprietário eram sobejamente conhecidos como insolventes.

(...)".

344 STJ, Quarta Turma, Recurso Especial n. 12.592-0 - São Paulo, Rel. Min. Sálvio de Figueiredo Teixeira, j. 23.03.1993:

"Voto do Relator:

(...)

Conforme se depreende, o aresto atacado deu provimento ao recurso do autor porque, à luz das provas dos autos, principalemnte em relação à falta de coerência entre a contestação e o mencionado depoimento pessoal, constatou ter havido ciência inequívoca de que o imóvel havia sido alienado ao autor, cabendo aos réus, em decorrência, efetuar o pagamento do aluguéis ao novo proprietário e não ao antigo. Assim, não se procedendo, concluiu o acórdão ser procrastinatório o intuito dos réus.

(...)

Razão, portanto, não assiste aos recorrentes quando alegam violação do artigo 935 do Código Civil, uma vez que, tendo ciência da alienação do imóvel e, também, de quem era o seu novo proprietário, não poderiam alegar boa-fé, condição essencial para ter-se o credor como putativo.

In casu, cientes da alienação do imóvel, ainda que dúvidas houvesse sobre quem seria o credor dos alugueres, deveriam os recorrentes diligenciar no sentido de obeterem certeza ou, ainda, caso não fosse possível , ajuizarem, nos termos dos arts. 895, CPC, e 973, IV, CC, ação de consignação, depositanto a quantia devida e requerendo a citação dos que acreditavam ser os possíveis credores. O que não podiam era efetuar o pagamento dos laocativos ao antigo proprietário se não tinham certeza de ser ele o verdadeiro credor.

(...)".

345 STJ, Quarta Turma, Recurso Especial n. 1.044.673 - São Paulo, Rel. Min. João Otávio de Noronha, j. 02.06.2009:

"Voto do Relator:

Versam os autos sobre pagamento de seguro a pessoa diversa do beneficiário indicado pelo segurado. A recorrida era beneficiária de duas apólices de seguro de vida de seu esposo, Sr. (...). Após o falecimento deste, a recorrente efetuou o pagamento de $50 \%$ de uma das apólices a cada uma das filhas, pagando à recorrida $100 \%$ da outra apólice. 


\section{i) Contratos de Compra e Venda}

Nesta seara constam casos interessantes levados à apreciação do Superior Tribunal de Justiça.

Um deles, tratando da compra e venda de gado realizada pelo administrador da propriedade rural, porém seguido de negativa por parte do pecuarista de entrega da mercadoria. O substrato fático é complexo na medida em que o pecuarista alega que o seu administrador não detinha mandato mercantil para celebrar a compra e venda, visto que tratava-se de empregado detentor tão somente dos poderes gerais de administração, e que a ele não se ajustaria o conceito de comerciante e muito menos ao seu empregado, administrador, o de preposto mercantil. O negócio, em linhas gerais, consubstanciou-se na venda de determinado número de cabeças de gado a terceiros que crentes de estar contratanto com o representante do pecuarista, uma vez que ele se encontrava em viagem ao exterior, pagam o preço e não recebem a mercadoria. A este contrato, entrelaça-se outra compra e venda, também de gado, celebrada pelos mesmos compradores desta feita diretamente com o pecuarista quem não resistiu ao adminplemento desta segunda avença $^{346}$.

Alega a recorrente que as filhas do segurado eram credoras putativas, pois constavam como beneficiárias na apólice, alterada cerca de 6 (seis) anos antes do sinistro, e que o pagamento foi feito de boa-fé, inclusive na presença da recorrida.

(...)

A regra invocada pela recorrente preceitua que o pagamento realizado de boa-fé a credor putativo é válido ante a aplicação da teoria da aparência. É necessária, para tanto, que o erro seja escusável, por acreditar a parte estar tratando com quem deve receber o pagamento em questão. A boa-fé, por sua vez, se presume desde que inexistam provas de má-fé daquele que realizou o pagamento equivocado.

Não basta, porém, que o credor putativo como tal se apresente, sendo necessária a existência de elementos suficientes para induzir e convencer o devedor, cuja diligência não pode ser desprezada, pois ele tem, além do interesse, o dever de pagar o verdadeiro credor, devendo assegurar-se que o recebente é quem deve auferir o pagamento.

(...)

No caso em exame, consideradas as circuntâncias do caso concreto, não se afigura razoável a alegação de validade do pagamento pela seguradora.

A recorrente assevera que a recorrida assitiu ao pagamento efetuado às filhas do segurado, e por isso pretende obrigá-la a suportar o prejuízo e privá-la dos valores que lhe são devidos. Ocorre que, como bem anotado no acórdão recorrido, eirrelevante que a recorrida estivesse presente àquele ato, poi ela ignorava que tal pagamento era relativo à apólice que a contemplava. À beneficiária não se pode imputar o equívoco da seguradora, quando esta tinha o dever de conferir as apólices a liquidar.

Além disso, tivesse a empresa empregado a mínima diligência no exame dos documentos, não teria realizado pagamento a pessoa diversa daquele expressamente indicada pelo segurado. O que verifico é que a empresa, apesar de deter as informações corretas, não cumpriu com o seu dever de conferir os beneficiários da apólice, cometendo erro inescusável não acobertado pela teoria da aparência.

Inviável, pois, que se aceite o pagamento realizado como válido, sendo inaplicável a teoria da aparência ante a incúria da recorrente".

346 STJ, Quarta Turma, Recurso Especial n. 12.811-0 - Mato Grosso do Sul, Rel. Min. Sálvio de Figueiredo Teixeira, j. 31.05.1993: 
O tribunal, após revisitar autorizados ensinamentos doutrinários, fixou tratar-se o pecuarista de típico comerciante, na acepção daquele que pratica atos de comércio como profissão habitual; a compra e venda entabulada de claro negocio mercantil e o administrador de evidente preposto mercantil, portanto dotado de poderes para celebrar negócios obrigando o seu preponente desde que pertinentes à atividade ordinária do fundo de comércio. Dessa forma, reputou válido o negócio jurídico e obrigado o pecuarista a indenizar os compradores em razão do contrato por ele inadimplido ${ }^{347}$.

“Exposição: Cuida-se de 'ação ordinária de indenização por perdas e danos' ajuizada por (...) e (...) contra (...), alegando os autores:

a) - que em 18.12.84 firmaram contrato particular de compra e venda, denominado 'fica', com o réu, por intermédio de seu administrador e mandatário, (...);

b) - que, de acordo com referido instrumento, o réu lhes vendeu 300 (trezentos) bezerros pelo preço de (...), ficando obrigado a entregar referidos animais em 30.04.85;

c) - que o preço foi integralmente pago no ato da celebração do contrato, tendo sido dada plena e raza quitação pelo administrador;

d) - que posteriomente, em 02.03.85, celebraram nova avença, dessa feita diretamente com o réu, pela qual adiquiriram 100 (cem) vacas por (...), depositados na conta do suplicado via ordem de pagamento; e) - que lhes foram entregues, contudo, apenas 100 (cem) novilhos, tendo havido, portanto, parcial descumprimento do primeiro contrato, com a não entrega dos restantes 200 (duzentos) bezerros, e descumprimento integral da segunda avença, que tinha por objeto a transferência das 100 (cem) vacas. (...)".

347 STJ, Quarta Turma, Recurso Especial n. 12.811-0 - Mato Grosso do Sul, Rel. Min. Sálvio de Figueiredo Teixeira, j. 31.05.1993:

"Voto do Relator:

1. A questão fundamental a ser dirimida centra-se na natureza jurídica da compra e venda realizada. Se adstrita à órbita do Direito Civil ou se, ao contrário, configuradora de típico negócio mercantil.

(...)

4. No caso, o administrador, além da condição de gerente-geral da fazenda, derivada da relação de trabalho que mantinha com o recorrente, detinha também mandato por este outorgado.

Se essa procuração conferia poderes para aquisição e alienação, consoante afirmado pelo acórdão recorrido, ou se limitava a atribuir ao administrador poderes para representar o mandatário perante a Exatoria Estadual, como sustentado pelo recorrente, é questão que, a par de não possuir relevo decisivo, não comporta discussão nesta via.

O que importa considerar é que o vínculo empregatício e a outorga de mandato servem, no mínimo, como indício de prova escrita, que, roborada pela testemunhal e pela emprestada, podiam conduzir à induvidosa caracterização da existência de madato mercantil, como reconheceu a decisão impugnada, afinada por isso, às inteiras, ao disposto nos arts. 123 e 140 do Código Comercial, reputados violados pelo recorrente.

(...)

5. É certo que o mandato mercantil, decorrente da relação laboral entre comerciante e empregado, se limita ao objeto da mercancia. Assim é que o gerente ou vendedor de uma loja de automóveis, por exemplo, está autorizado a efetuar, mediante, o pagamento do preço, a tradição do veículo. Nesse mister, pode inclusive entabular negociação com o consumidor comprador, concedendo-lhe vantagens e descontos. E, caso tais concessões causem prejuízo ao comerciante, não pode este pretender resolver a obrigação que, por meio de seu preposto, assumiu com o terceiro de boa-fé. Impõe-se-lhe, em tais circunstâncias, haver repraração diretamente do empregado, que eventualmente haja descumprido as regras de venda preestabelecidas.

Não menos certo é, por outro lado, que o comerciário não está autorizado, pelo mandato que decorre do contrato de trabalho, a realizar, por exemplo, a alienação do fundo do comércio ou dos bens que o constituem (instalações). Tais atos, por não envolverem transferência de mercadorias, de produtos destinados por natureza e finalidade à comercialização, refogem sem dúvida às atribuições de um gerente ou vendedor, pelo que, se pelos mesmos praticados, configuram extrapolação inadmissível, não 
Em uma série de acórdãos e ao longo de vários anos teve o tribunal oportunidade de debater os casos versando sobre a aquisição de mercadoria estrangeira, normalmente automóveis, importados irregularmente para o Brasil e posteriormente repassados a consumidores de boa-fé. A Corte Superior pacificou o seu entendimento no sentido de que sendo a mercadoria adquirida de empresa regularmente constituída no mercado interno e mediante a emissão do competente documento fiscal, presume-se a boa-fé do consumidor, não se lhe sendo aplicada a sanção do perdimento do bem importanto, uma vez que considerou demasiado exagero exigir do adquirente a conferência e investigação acerca da legalidade da importação ${ }^{348}$.

se havendo como reconhecer boa-fé ou erro escusável ao tercerio adquirente. Nessas hipóteses, portanto, não se mostra aplicável a teoria da aparência.

6. Feitas essa considerações, resta definir que situação se enquadra a espécie dos autos.

Conforme salientado, o recorrente tinha por prática habitual a compra e venda de gado, objetivando auferir lucro e recursos para manutenção da fazenda e do negócio. Fato que releva notar nesse contexto foi a venda das 100 (cem) vacas realizada pelo próprio recorrente aos mesmos adquirentes dos 300 (trezentos) bezerros, venda realizada após o retorno da viagem que empreendera ao exterior, durante a qual, na sua ausência, foi celebrado pelo administrador o referido contrado 'fica'.

Disso se depreende que a venda de gado constituía objeto do comércio desenvolvido pelo recorrente.

O administrador não vendeu outra coisa senão gado, mais precisamente novilhos, cuja entrega, talvez em razão da necessidade de amamentação, ficou postergada para o futuro (pelo contrato 'fica', ficam também os alienantes obrigados a entregar os bens). Não alienou imóveis, equipamentos ou máquinas. (...)".

348 STJ, Primeira Seção, Embargos de Divergência em Recurso Especial n. 535.536 - Paraná - Rel. Min. Humberto Martins, j. 13.09.2006:

"Voto do Relator:

Consta dos autos que a embargante impetrou Mandado de Segurança com o objetivo de assegurar o direito líquido e certo de manter-se na posse do automóvel Mitsubishi, modelo Expo, tipo Van, ano de fabricação e modelo 1993, introduzido no território nacional por força de medida liminar em mandado de segurança que teve, ao final, a ordem denegada.

(...)

No caso em comento, a mercadoria foi regularmente adquirida de empresa constituída no mercado interno.

Este Tribunal, em outras oportunidades, já se menifestou no sentido de que não se pode exigir do adquirente de mercadoria estrangeira, no mercado interno, o cuidado de investigação antes de efetuar a compra, a respeito da legalidade da importação ou regularidade do alienante.

Por outro lado, do adquirente exige-se apenas que a compra tenha sido feita legalmente, com expedição de nota fiscal, documento exigível nessas aquisições.

(...)

A boa-fé configura-se em um estado psicológico que faz com que a pessoa acredite estar diante de uma operação lícita, colocando-a em uma situação de ignorância acerca da realidade dos fatos e da lesão a direito alheio.

$\mathrm{Na}$ hipótese dos autos, afigura-se que o sistema normativo e o poder judiciário devem assegurar ao adquirente de boa-fé, a garantia de que o negócio jurídico realizado, qual seja, compra e venda de automóvel importado, não seja frustrado em razão de irregularidade aferida pelo Fisco.

(...)".

No mesmo sentido: STJ, Primeira Turma, Recurso Especial n. 23.513-7 - Rio de Janeiro, Rel. Min. Humberto Gomes de Barros, j. 20.10.1993; STJ, Segunda Turma, Recurso Especial n. 15.073-0 Distrito Federal, Rel. Min. Peçanha Martins, j. 27.04.1994; STJ, Segunda Turma, Recurso Especial n. 11.137-0 - Pernanbuco, Rel. Min. Ari Pargendler, j. 11.10.1995; STJ, Primeira Turma, Recurso Especial n. 79.764 - Distrito Federal, Rel. Min. Humberto Gomes de Barros, j. 20.05.1996; STJ, Segunda Turma, Recurso Especial n. 81.544 - Distrito Federal, Rel. Min. Peçanha Martins, j. 
Ainda tratando da compra e venda de veículo, o Superior Tribunal de Justiça julgou

a demanda de um consumidor que adquiriu um automóvel supostamente zero quilômetro, que mais tarde detectou-se estar avariado em razão de um acidente ocorrido durante um "test drive" ${ }^{349}$. Ao perseguir junto ao Poder Judiciário a indenização inerente ao dano

20.05.1996; STJ, Primeira Turma, Recurso Especial n. 90.437 - Distrito Federal, Rel. Min. José Delgado, j. 27.08.1996; STJ, Primeira Turma, Recurso Especial n. 102.146 - Distrito Federal, Rel. Min. Humberto Gomes de Barros, j. 13.03.1997; STJ, Segunda Turma, Recurso Especial n. 94.980, Rel. Min. Hélio Mosimann, j. 17.03.1997; STJ, Segunda Turma, Recurso Especial n. 160.876 - São Paulo, Rel. Min. Hélio Mosimann, j. 16.04.1998; STJ, Segunda Turma, Recurso Especial n. 207.665 - Santa Catarina, Rel. Min. Francisco Peçanha Martins, j. 15.03.2001; STJ, Primeira Turma, Recurso Especial n. 315.553 - Paraná, Rel. Min. Humberto Gomes de Barros, j. 04.09.2001; STJ, Primeira Turma, Agravo Regimental no Recurso Especial n. 316.093 - Paraná, Rel. Min. Milton Luiz Pereira, j. 11.12.2001; STJ, Primeira Turma, Recurso Especial n. 345.577 - Paraná, Rel. Min. José Delgado, j. 05.02.2002; STJ, Primeira Turma, Agravo Regimental no Agravo de Instrumento n. 423.062 - Paraná, Rel. Min. José Delgado, j. 04.04.2002; STJ, Segunda Turma, Agravo Regimental no Recurso Especial n. 379.588 - Rio Grande do Sul, Rel. Min. Paulo Medina, j. 14.05.2002; STJ, Primeira Turma, Recurso Especial n. 489.618 - Paraná, Rel. Min. José Delgado, j. 08.04.2003; STJ, Segunda Turma, Recurso Especial n. 505.709 - Rio Grande do Sul, Rel. Min. Franciulli Netto, j. 19.08.2003; STJ, Primeira Turma, Agravo Regimental no Agravo de Instrumento n. 487.282 - Rio Grande do Sul, Rel. Min. Luiz Fux, j. 20.11.2003; STJ, Segunda Turma, Recurso Especial n. 325.947 - Paraná, Rel. Min. Franciulli Netto, j. 25.11.2003; STJ, Segunda Turma, Agravo Regimental no Recurso Especial n. 428.873 Paraná, Rel. Min. Franciulli Netto, j. 05.02.2004; STJ, Segunda Turma, Agravo Regimental no Recurso Especial n. 416.989 - Paraná, Rel. Min. Franciulli Netto, j. 16.03.2004; STJ, Primeira Turma, Agravo Regimental no Recurso Especial n. 603.619 - Rio de Janeiro, Rel. Min. José Delgado, j. 06.05.2004; STJ, Segunda Turma, Agravo Regimental no Agravo de Instrumento n. 518.995 - Rio Grande do Sul, Rel. Min. Castro Meira, j. 11.05.2004; STJ, Segunda Turma, Recurso Especial n. 634.046 - Rio de Janeiro, Rel. Min. Eliana Calmon, j. 07.10.2004; STJ, Primeira Turma, Recurso Especial n. 658.218 Rio Grande do Sul, Rel. Min. Luiz Fux, j. 22.03.2005; STJ, Segunda Turma, Recurso Especial n. 644.613 - Rio Grande do Sul, Rel. Min. Eliana Calmon, j. 20.10.2005; STJ, Segunda Turma, Recurso Especial n. 763.464 - Distrito Federal, Rel Min. João Otávio de Noronha, j. 21.03.2006; STJ, Primeira Turma, Agravo Regimental no Agravo de Instrumento n. 744.849 - São Paulo, Rel. Min. José Delgado, j. 16.05.2006 e STJ, Segunda Turma, Recurso Especial n. 412.345 - Paraná, Rel. Min. João Otávio de Noronha, j. 01.06.2006.

Repisando o mesmo entendimento, mas a contrário senso afastando a pressunção de boa-fé em favor dos adquirentes de mercadoria irregularmente importada, o Superior Tribunal de Justiça fez incidir a sanção do perdimento do bem àqueles que o adquiriram de particulares e sem a emissão de nota fiscal, imputando-lhes, nessa hipótese específica, a assunção do risco. É o caso do STJ, Segunda Turma, Recurso Especial n. 436.342 - Santa Catarina, Rel. Min. Eliana Calmon, j. 03.10.2002:

"Ementa: TRIBUTÁRIO - PENA DE PERDIMENTO - VEÍCULO IMPORTADO IRREGULARMENTE - AQUISIÇÃO DE PARTICULAR - PRESUNÇÃO DE BOA-FÉ QUE SE AFASTA.

1. Segundo a jurisprudência desta Corte, a aquisição de mercadoria importada, mediante nota fiscal emitida por firma regularmente estabelecida, gera a presunção de boa-fé do adquirente. 2. A contrário senso, se a aquisição deu-se de particular, cabia ao adquirente averiguar a regularidade da importação, a fim de eximir-se do ônus de responder administrativa ou judicialmente, pois ao não cercar-se das cautelas necessárias, assumiu o risco pela irregular importação. Presunção de boa-fé que se afasta.

3. Recurso especial improvido".

E ainda: STJ. Segunda Turma, Recurso Especial n. 512.126 - Paraná, Rel. Min. Franciulli Netto, j. 19.08.2003 e STJ, Segunda Turma, Recurso Especial n. 380.179 - Paraná, Rel. Min. Franciulli Netto, j. 26.10.2004.

349 STJ, Terceira Turma, Recurso Especial n. 369.971 - Minas Gerais, Rel. Min. Castro Filho, j. 16.12.2003:

"Relatório:

Narram os autos que, em 02/09/97, (...) adquiriu junto à (...), um veículo importado, supostamente zero quilômetro, marca Ford, modelo Taurus LX, por meio de contrato de arrendamento mercantil. 
suportado, o consumidor deparou-se com a alegação por parte da concessionária de que seria parte ilegítima na ação judicial, uma vez que o veículo fora adquirido por meio de contrato de arrendamento mercantil e a relação jurídica do consumidor seria com a empresa responsável pelo leasing, pertencente ao mesmo grupo econômico da revenda de veículos. Novamente invocando a "Teoria da Aparência" em socorro da boa-fé do consumidor, os julgadores levando em conta que o negócio jurídico fora celebrado nas dependências da concessionária, por meio de seus funcionários, além da conduta ardilosa da revenda ao repassar como zero quilômetro veículo acidentado, induzindo o adquirente a erro, fixou entendimento no sentido de responsabilizar a responsável pela operação embora pessoa jurídica distinta daquela que formalmente celebrara o contrato objeto da discussão judicial $^{350}$.

\section{j) Contrato Desportivo}

Trata-se de demanda entre dois Clubes de Futebol acerca de dívida oriunda de contrato de compra e venda de direitos federativos de atleta profissional, na qual a parte

Tendo apresentado alguns problemas de ordem técnica, relacionados a sinais luminosos do air bag e desgaste excessivo de pneus, por algumas vezes o adquirente se deslocou até a concessionária, sem que conseguisse sanar em definitivo tais defeitos, até que veio a saber, através de um ex-empregado da reclamada, que o veículo fora acidentado em um test drive, em agosto de 1997, tendo sua lataria dianteira totalmente danificada, além da barra de direção etc; e, após serem realizados os consertos necessários, foi ele vendido como se fosse novo.

(...)".

$350 \quad$ STJ, Terceira Turma, Recurso Especial n. 369.971 - Minas Gerais, Rel. Min. Castro Filho, j. 16.12.2003:

"Voto do Relator:

Trata-se de recurso especial interposto contra acórdão que reconheceu a legitimidade passiva ad causam da concessionária, para responder por ação indenizatória c/c rescisão de contrato, em decorrência de danos causados a consumidor, que adquiriu como zero quilômetro, por meio de contrato de leasing firmado com empresa do mesmo grupo econômico, veículo que já havia sofrido colisão.

No presente arrazoado, insiste a concessionária na sua ilegitimidade passiva para a causa, vez que não teria celebrado com a autora, ora recorrida, o contrato de leasing, objeto da pretensão, mas a (...), pessoa jurídica absolutamente distinta e real proprietária do bem, a qual, no entender da recorrente, deveria integrar a presente lide na condição de litisconsorte passiva necessária.

Com efeito, em que pese a argumentação expendida, depreende-se que o contrato foi firmado no interior da concessionária, através da intervenção direta de seus empregados, dando a idéia de que o negócio fora realizado com uma única empresa, circunstância que autoriza a aplicação da teoria da aparência, cujo escopo é a preservação da boa-fé nas relações jurídicas, fazendo com que, em determinados casos, os atos realizados por uma pessoa possam ter efeitos sobre os atos de outra.

(...)

É de se ter presente, ademais, que, in casu, a ação reparatória teve origem em conduta ardilosa da própria concessionária, ao tentar vender como novo, após os devidos reparos, veículo que já havia sofrido colisão, não havendo como ser afastada, portanto, sua responsabilidade pelos prejuízos que foram causados ao consumidor, o qual não teria jamais celebrado o negócio se lhe fossem dados a conhecer os defeitos do veículo. Foi a revendedora autorizada, aliás, não só quem atuou para que o consumidor viesse a adquirir o automóvel, como também quem realizou todos os serviços na tentativa de solucionar os problemas apresentados, tornando-se, por isso, responsável pela reparação decorrente do vício nele constatado.

(...)". 
exquenda busca a declaração de nulidade do título executivo, no caso o próprio contrato de compra e venda, visto que o seu instrumento somente recebera a assintura do Presidente da Instituição Esportiva devedora enquanto o seu Estatuto Social reclamava também a firma do Vice-Presidente de Finanças do clube. Mantendo a decisão hostilizada na via excepcional, o Superior Tribunal de Justiça fez incidir ao caso concreto a "Teoria da Aparência" para refutar a oponibilidade da exeqüenda e reputar liso e escorreito o título executivo, visto que o vício apontado teve origem em ato do próprio clube executado, o qual restou obrigado pelo ato isolado do seu Presidente e pela homenagem prestada pela Corte Superior à boa-fé objetiva do clube exquente ${ }^{351}$.

\section{k) Representação Processual}

Trata-se de Recurso Especial interposto em sede de Mandado de Segurança questionando a anulação de certame licitatório por ato de império de Administração Pública. No bojo da discussão, o ente público argüiu a irregularidade da representação processual da pessoa jurídica demandante porque deixara de juntar aos autos do processo os seus estatutos sociais, de modo a comprovar a legitimidade do outorgante dos poderes para atuar em juízo no interesse da empresa. A solução dos julgadores aplica a "Teoria da Aparência" no âmbito da representação processual, considerando que somente seria indispensável a juntada dos reclamados documentos sociais se houvesse dúvidas quanto à legitimidade do outorgante de poderes para fazê-lo em nome da passoa jurídica demandante, o que, no caso concreto, não se verificava, até mesmo porque o mesmo

351 STJ, Quarta Turma, Recurso Especial n. 681.856 - Rio Grande do Sul, Rel. Min. Hélio Quaglia Barbosa, j. 12.06.2007:

"Voto do Relator:

(...)

2. Consoante acima relatado, busca o recorrente a declaração de nulidade do título que embasa a execução contra si proposta, em virtude de alegado vício na sua constituição, por faltar ao contrato de compra e venda dos direitos federativos de atleta profissional de futebol realizado com o recorrido, a assinatura do seu vice-presidente de finanças, a despeito de expressa exigência nesse sentido, imposta pelo estatuto do clube.

(...)

3. Incensurável o tratamento dado ao caso pela Corte de origem, não só pela distinção feita entre natureza do contrato exequiendo (art. 585, II, do CPC), face aos títulos executivos extrajudiciais relacionados na regra estatutária, cujo descumprimento teria o condão de inviabilizar o processo executivo, mas, principalmente, pela repulsa à invocação de suposto vício na constituição do pacto, levado a efeito pelo próprio executado, uma vez havendo o recorrido agido de boa-fé e alicerçado na teoria da aparência, que legitimava a representação social por quem se apresentava como habilitado à negociação empreendida.

Nada mais natural, militando, na espécie, como milita, em favor do recorrido, a denominada teoria da aparência, que se preserve, até em respeito ao princípio da boa-fé contratual, o negócio jurídico, com a executividade que lhe é própria, uma vez obrigada a sociedade pelo ato de seu presidente.

(...)". 
outorgante representara a pessoa jurídica em outro certame, este no âmbito $\operatorname{administrativo~}^{352}$.

\section{1) Agente Captador de Recursos}

Nesse julgado, o Superior Tribunal de Justiça enfrentou caso concreto em que um captador de recursos financeiros, intermediário de uma distribuidora de títulos e valores mobiliários, era o responsável pela captação em nome da apontada empresa em determinada região. Ocorre, no entanto, que um dos clientes vai a juízo contra a distribuidora alegando que repassara recursos ao captador, porém, não os recebera de volta, como acordado, deparando-se com a negativa ao ressarcimento por parte da parte acionada sob a alegação de que o captador agira com excesso de poderes e, portanto, considerandose a pessoa jurídica indene de responsabilidade ${ }^{353}$.

A Corte Superior julgou por bem reformar a decisão atacada que negara a responsabilidade da distribuidora e aplicando a "Teoria da Aparência" consignando que o agente intermediário, autorizado a captar recursos, e que efetivamente recebera os valores recobrados, entendeu, em homenagem à boa-fé do cliente, que não havia como afastar a responsabilidade da pessoa jurídica relutante ${ }^{354}$.

352 STJ, Primeira Turma, Recurso Especial n. 147.030 - Amazonas, Rel. Min. José Delgado, j. 23.10.1997: "Voto do Relator:

(...)

O recurso especial, conforme consta no relatório e se depreende da peça que o contém, concentra-se em apontar, apenas, violação ao art. 237, IV, c/c o art. 301, VIII, do CPC, por ter o acórdão afastado a preliminar de vício na representação processual, (...).

As razões com que a preliminar de ilegitimidade da representação processual foi afastada merecem ser homenageadas.

(...)

A teoria da aparência na prática dos atos processuais também é aplicada. No caso, a preliminar só teria êxito se a autoridade apontada como coatora tivesse demonstrado, com prova inequívoca, o fato alegado, isto é, que o Sr. (...) não tinha autorização estatutária para representar a empresa. Os fatos apreciados pelo Egrégio Tribunal de Justiça e que foram, no particular, examinados, com a conclusão de que havia uma presunção a ser aceita, tendo em vista que o referido senhor havia praticado atos de representação na empresa no curso do procedimento administrativo licitatório.

(...)".

353 STJ, Quarta Turma, Recurso Especial n. 276.025 - São Paulo, Rel. Min. Ruy Rosado de Aguiar, j. 12.12.200:

"Relatório:

(...) ajuizou ação ordinária de obrigação de fazer contra (...) Distribuidora de Títulos e Valores Mobiliários, objetivando a entrega de letra de câmbio ou seu equivalente em dinheiro, correspondente à aplicação financeira feita com a intermediação do agente autônomo de investimentos (...). A distribuidora se nega à restituição, sob o fundamento de que tal agente agiu com excesso de poderes ao desviar os recursos a ele confiados.

(...)".

354 STJ, Quarta Turma, Recurso Especial n. 276.025 - São Paulo, Rel. Min. Ruy Rosado de Aguiar, j. 12.12.200: 
m) Responsabilidade Civil

Finalmente convém colacionar um interessante julgado no qual o Superior Tribunal de Justiça enfrentou discussão atinente à responsabilidade civil no âmbito da rede mundial de computadores, a internet, e seus novéis instrumentos de circulação e divulgação de informações. O judicioso voto do relator, Ministro Fernando Gonçalves, esclarece o papel dos provedores de internet, no qual se inserem os serviços de correio eletrônico (e-mail), chave de busca e a hospedagem de páginas eletrônicas (web sites), sendo este último o que interessa ao delinde da demanda, porque no caso concreto a autora do feito recobra indenização por haver tido sua imagem e honra conspurcados por meio de sítio eletrônico criado por um anônimo, porém hospedado por provedor internacional pertencente ao mesmo grupo econômico do provedor nacional acionado judicialmente. Inaugurado o certame, o provedor nacional alegou, em síntese, sua incapacidade técnica para retirar o conteúdo ofensido do ar e a sua irresponsabilidade no tocante ao pedido indenizatório, visto que o provedor responsável pela hospedagem do sítio eletrônico objeto do litígio seria a sua empresa controladora, também provedora de internet, porém sediada no exterior $^{355}$.

\footnotetext{
"Voto do Relator:

1. O r. acórdão recorrido negou provimento ao apelo do autor por 'ausência de prova constitutiva do seu direito' (ementa de fl. 447). Admitiu, no entanto, que (...) recebia numerário para investir na (...) ('Consta dos autos que (...) exercia a função de agente autônomo de investimento, e credenciado pela ré com a finalidade de, em nome dela, promover a captação de recursos destinados aos investimentos no mercado de capitais', fl. 450), e que há recibo, fornecido por (...), da importância entregue pelo autor. Excluiu a responsabilidade da (...) porque o presente investimento era para aquisição de letras de câmbio, e não para investimento no fundo ao portador da (...), sem indicar o recibo a data do vencimento, valor de resgate e juros, além de conter um carimbo que não teria sido aposto por (...).

2. Ocorre que o fato constitutivo do direito do autor consistia na entrega do numerário a quem se apresentava na cidade e na região como agente autorizado a captar recursos para a (...), (...).

(...)

4. Nesse quadro, tenho que a assertiva de que o autor não se desincumbiu do ônus de provar o fato constitutivo do seu direito causou ofensa ao art. 333, I, do CPC, pois o próprio acórdão recorrido admitiu que a pessoa autorizada a captar recursos para instituição finaceira recebera o numerário com a finalidade de repasse, conforme demonstra o recibo. Os pontos inidcados no r. acórdão para desqualificar essa prova não têm relevância atribuída pela egrégia Câmara, uma vez que não era do aplicador a incumbência de fiscalizar o desempenho e o conteúdo da documentação emitida pelo agente autorizado a angariar recursos para a (...). Demonstrados e admitidos os fatos enumerados no r. acórdão, cumpria aplicar ao caso a teoria da aparência, indispensável para a proteção do terceiro de boa-fé. $\mathrm{Na}$ verdade, cabia à instituição que se beneficiava aos serviços de (...) provar má-fé do sedizente aplicador, e não o inverso.

(...)".

355 STJ, Quarta Turma, Recurso Especial n. 1.021.987 - Rio Grande do Norte, Rel. Min. Fernando Gonçalves, j. 07.10.2008:

"Voto do Relator:

Os denominados 'provedores de internet' são pessoas físicas ou jurídicas que exercem diversas funções no âmbito da rede mundial de computadores. A partir do tipo de atividade desenvolvida podem ser divididos em provedores de acesso, provedores de serviços e provedores de conteúdo.
} 
Dando seguimento à análise da controvérsia, esta restou fixada na incidência da "Teoria da Aparência" ao caso concreto tendo em vista que a empresa acionada era controlada da empresa responsável pela prática dos medidas ordenadas pelo juízo. Sustentou o acórdão que o provedor brasileiro aprenta-se com a mesma logomarca do provedor estrangeiro e o endereço deste remete ao protal do provedor nacional, o que não permite ao usuário distinguir uma pessoa jurídica da outra, aparentando tratar-se de uma só. Desse modo, levando em conta os preceitos do microssistema consumerista e o fato de que a empresa brasileira beneficia-se da semelhança com sua controladora norteamericana, seria de se imputar à pessoa jurídica nacional também o ônus de responder pelos atos da estrangeira e no toacante à alegada incapacidade técnica que a controlada envidasse os esforços junto à sua controladora para que esta desse efetividade à ordem judicial $^{356}$.

Os provedores de serviços são responsáveis, por exemplo, pelos serviços de correio eletrônico, hospedagem de páginas eletrônicas e chave de busca. Dentre esses, o que nos interessa para a compreensão do tema em debate, é a hospedagem de páginas eletrônicas, que incluem, no mais das vezes, a disponibilização de ferramentas para o usuário produzir uma página e o fornencimento de espaço para armazenamento dos dados criados.

Na espécie, ingressa a autora com pedido de antecipação de tutela requerendo seja retirada da rede muncial página eletrônica de conteúdo ofensivo a sua imagem e a sua honra, criada por usuário, até então, anônimo. O pedido é provido, sendo condenada a recorrente a determinação, sob pena de multa diária.

Sustenta a recorrente, porém, não ter capacidade técnica ou jurídica para executar o quanto ordenado, pois não seria o provedor das informações nela contidas.

Assegura, nesse passo, que o site, objeto da lide, foi criado e hospedado por um usuário da internet com o uso de uma ferramenta oferecida pela empresa americana (...), no portal (...), enquanto o seu portal é o (...).

(...)".

356 STJ, Quarta Turma, Recurso Especial n. 1.021.987 - Rio Grande do Norte, Rel. Min. Fernando Gonçalves, j. 07.10.2008:

"Voto do Relator:

(...)

Nesse contexto, percebe-se que o cerne da controvérsia cinge-se à possibilidade de aplicação da teoria da aparência ao caso, acenando a recorrente com a impropriedade de se adotar tal entendimento, tendo em vista que o Código de Defesa do Consumidor fala somente em responsabilidade subsidiária de participante do mesmo grupo econômico e não em responsabilidade direta.

(...)

No caso em apreço, é fato que a (...) Brasil apresenta-se aos consumidores utilizando a mesma logomarca da empresa americana. Além disso, ao digitar na rede mundial o endereço trazido nas razões do recurso como sendo da (...) abre-se, na realidade, a página da (...) Brasil. Diante dessa moldura fática, é de se supor que o consumidor não distingue com clareza as divisas entre a empresa americana e sua correspondente nacional. Uma aparentando ser a outra.

Assim, sendo direito do consumidor a facilitação da defesa de seus direitos e a efetiva reparação dos danos morais experimentados, é de se concluir pela legitimidade passiva da recorrente para responder à recorrida o ônus de demandar empresa internacional, mormente se a demora na retirada das informações caluniosas é fator preponderante para agravar-lhe o sofrimento moral.

(...)

Ademais, é de se considerar que a empresa brasileira aufere diversos benefícios quando se apresenta ao mercado de forma tão semelhante a sua controladora americana, deve, também, responder pelos riscos de tal condurta. 


\section{CONCLUSÃO}

A primeira parte do trabalho permite aferir que a pessoa jurídica é uma das mais magníficas construções da ciência jurídica, na medida que permite ao homem e à sociedade conjugarem esforços e capitais para o atingimento de objetivos grandiosos, impossíveis de ser alcançados isoladamente pela pessoa física em razão de suas limitações e efemeridade. Além do mais, permite o resguardo da fazenda particular e familiar das pessoas físicas, incentivando-as por meio da mitigação do risco patrimonial a emprrenderem grandes projetos.

Para tanto cuidou o direito de as dotar da necessária personalidade jurídica, habilitando-as para a prática dos atos e negócios do comércio jurídico, por meio de seus órgãos, que ao presentá-la, são ela própria, habilitada e de fato exercendo sua capacidade de direito na ordem civil, na medida que o direito brasileiro, muito bem, acolheu a construção germânica nesse sentido, em detrimento da velha concepção romanística.

E na esteira dessa problemática acerca da presentação, e também da possível representação das pessoas jurídicas, é que surgem as discussões passíveis de incidência da “Teoria da Aparência". Também construção genial da ciência jurídica, por esta teoria se privilegia a aparência de direito em prejuízo da realidade jurídica e em homenagem ao princípio da boa-fé.

Depreende-se que as principais Cortes Superiores do Brasil, Supremo Tribunal Federal e Superior Tribunal de Justiça, são pródigas em admitir a incidência da "Teoria da Aparência", sempre em deferência ao princípio da boa-fé daquele que reputa estar celebrando negócio jurídico com um presentante ou representante da pessoa jurídica.

Vale, no entanto, a admoestação de cautela nesse tocante, visto que deve se ter a apontada "Teoria da Aparência" como tese de defesa, mas nunca como supedâneo para dispensa dos cuidados na sempre necessária análise dos poderes de presentação e representação que devem anteceder a celebração dos negócios jurídicos, principalmente com as pessoas jurídicas.

(...)

Cumpre ressaltar, ainda, que à recorrente foi determinada a retirada da página causadora de dano à imagem da recorrida, mas no caso de impossibilidade técnica, foi estabelecido que adotasse os procedimentos necessários junto à (...) (sua controladora) para alcançar o mesmo fim, não lhe auxiliando, portanto, a argumentação no sentido de que não tem capacidade técnica para cumprir o quanto determinado.

$(\ldots)$. 


\section{BIBLIOGRAFIA}

Arruda Alvim, Cerqueira César, Joaquim Portes de, e Rosas, Roberto (coords.), Aspectos Controvertidos do Novo Código Civil - Escritos em homenagem ao Ministro José Carlos Moreira Alves, São Paulo, RT, 2003.

AzEvedo, Antônio Junqueira de, Negócio Jurídico - Existência, Validade e Eficácia, $4^{\mathrm{a}}$ ed., São Paulo, Saraiva, 2007.

Bevilaqua, Clovis, Em defeza do Projecto de Codigo Civil Brazileiro, Rio de Janeiro, Francisco Alves, 1906.

BITTAR, Carlos Alberto, Os Direitos da Personalidade, $3^{\mathrm{a}}$ ed. atualizada por Eduardo Carlos Bianca Bittar, Rio de Janeiro, Forense Universitária, 1999.

Borges, João Eunápio, Curso de Direito Comercial Terrestre, 5 ${ }^{\mathrm{a}}$ ed., Rio de Janeiro, Forense, 1971.

Borghi, Hélio, Teoria da Aparência no Direito Brasileiro - Aparência de Direito e Aparência no Direito, no Direito Privado e no Direito Processual Civil. Confrontações a Aplicações, inclusive na Jurisprudência, São Paulo, LEJUS, 1999. , Ausência e Aparência de Direito, Erro e a Simulação, in RT 734 (1996), pp. 763-771.

Carvalhosa, Modesto, Comentários à Lei de Sociedades Anônimas, $3^{\circ}$ vol., $4^{\mathrm{a}}$ ed., São Paulo, Saraiva, 2009.

Coelho, Fábio Ulhoa, Curso de Direito Civil, vol. 1, 2ª ed., São Paulo, Saraiva, 2006. , Desconsideração da Personalidade Jurídica, São Paulo, RT, 1989.

Colin, Ambrosio e CAPITANT, H., (s/ título original), trad. esp. de Revista General de Legislacion y Jurisprudencia, Curso Elemental de Derecho Civil - Contratos Usuales, tomo quarto, $3^{\text {a }}$ ed., Madrid, Reus, 1981. 
Comparato, Fábio Konder, e Salomão Filho, Calixto, O Poder de Controle na Sociedade Anônima, $5^{\mathrm{a}}$ ed., Rio de Janeiro, Forense, 2008.

Comparato, Fábio Konder, O Poder de Controle na Sociedade Anônima, $2^{\mathrm{a}}$ ed., São Paulo, RT, 1977.

Aparência de Representação: a Insustentabilidade de uma Teoria, in Revista de Direito Mercantil, Industrial, Econômico e Financeiro, vol. 111 (1998), pp. 3944.

CorrêA, Alexandre, e SCIASCIA, Gaetano, Manual de Direito Romano, 6a ed., São Paulo, RT, 1988.

Dall'Agnol Junior, Antonio Janyr, Citação da Pessoa Jurídica, in Revista da Associação dos Juízes do Rio Grande do Sul - AJURIS, vol. 52 (1991), pp. 228-244.

De CupIS, Adriano, (s/ título original), trad. port. de Adriano Vera Jardim e Antonio Miguel Caeiro, Os Direitos da Personalidade, Lisboa, Morais, 1961.

De Mattia, Fábio Maria, Aparência de Representação, São Paulo, Gaetano Dibenedetto, 1999.

De Plácido e Silva, Tratado de Mandato e Prática de Procurações, $1^{\circ}$ vol., $3^{\mathrm{a}}$ ed., Rio de Janeiro - São Paulo, Forense, 1959.

, Tratado de Mandato e Prática de Procurações, $2^{\circ}$ vol., $3^{\mathrm{a}}$ ed., Rio de Janeiro, Forense, 1959.

, Noções Práticas de Direito Comercial, $13^{\mathrm{a}}$ ed., atualizada por Waldir Vitral, Rio de Janeiro, Forense, 1988.

Ferreira Filho, Manoel Gonçalves, Curso de Direito Cosntitucional, 19a ed., São Paulo, Saraiva, 1992.

FLuME, Werner, Allgemeiner Teil des Bürgerlichen Rechts. Zweiter Band, Das Rechtsgeschäft. Vierte. unveränderte Auflage, 1992, trd. esp. de José Maria Miquel González e Esther Gómez Calle, El Negocio Jurídico - Parte General Del Derecho Civil - Tomo Segundo, $4^{\mathrm{a}}$ ed., Madrid, Fundación Cultural del Notariado, 1998. 
FrançA, Erasmo Valladão Azevedo e Novaes (coord.), Direito Societário Contemporâneo I, São Paulo, Qiartier Latin, 2009.

, Temas de Direito Societário, Falimentar e Teoria da Empresa, São Paulo, Malheiros, 2009.

Gama, Afonso Dionísio, Das Procurações - Teoria e Prática, $6^{\mathrm{a}}$ ed. atualizada por J. do Amaral Gurgel, São Paulo, Saraiva, s/d.

Gomes, José Jairo, Teoria Geral do Direito Civil, Belo Horizonte, Del Rey, 2009.

, Direito Civil - Introdução e Parte Geral, Belo Horizonte, Del Rey, 2006.

GoMes, Orlando, Introdução ao Direito Civil, $19^{\mathrm{a}}$ ed. atualizada por Edivaldo Brito e Reginalda Paranhos de Brito, Rio de Janeiro, Forense, 2007.

_, Questões de Direito Civil (Pareceres), 4ª ed., São Paulo, Saraiva, 1976.

, Novas Questões de Direito Civil, São Paulo, Saraiva, 1979.

, Transformações Gerais do Direito das Obrigações, São Paulo, RT, 1967.

KELSEN, Hans, Reine Rechtslehre, 1960, trad. port. de João Batista Machado, Teoria Pura do Direito, 6a ed., São Paulo, Martins Fontes, 1998.

, Reine Rechtslehre, trad, port. de José Cretella Jr. e Agnes Cretella, Teoria

Pura do Direito - Introdução à Problemática Científica do Direito - Versão Condensada pelo próprio Autor, São Paulo, RT, 2006.

KüMPEl, Vitor Frederico, Teoria da Aparência no Código Civil de 2002, São Paulo, Método, 2007.

LEVY, Artur, Pessoas Jurídicas - Conceito e Natureza de "Órgãos” nas Sociedades, Associações Civis, Fundações e Corporações, in Revista Forense, vol. XCVIII (1944), pp. 227-232.

Lopes, Miguel Maria de Serpa, Curso de Direito Civil - Introdução, Parte Geral e Teoria dos Negócios Jurídicos, vol. 1, 6 a ed. atualizada por José Serpa Santa Maria, Rio de Janeiro, Freitas Bastos, 1988. 
MAIA JÚnIOR, Mairan Gonçalves, A Representação no Negócio Jurídico, $2^{\mathrm{a}}$ ed., São Paulo, RT, 2004.

Malheiros, Álvaro, Aparência de Direito, in Revista de Direito Civil, Imobiliário, Agrário e Empresarial, vol. 6 (1978), pp. 41-77.

MARChI, Eduardo C. Silveira, Guia de Metodologia Jurídica - Teses, Monografias e Artigos, $2^{\mathrm{a}}$ ed., São Paulo, Saraiva, 2009.

MARCondes, Sílvio, Problemas de Direito Mercantil, São Paulo, Max Limonad, 1970.

MARKy, Thomas, Curso Elementar de Direito Romano, $8^{\text {a }}$ ed., São Paulo, Saraiva, 1995.

Mazeud, Henri y Léon, e MAZeud, Jean, Leçons de Droit Civil, trad. esp. de Luis AlcaláZamora y Castillo, Lecciones de Derecho Civil - Parte Primera - Introdución al Estudio del Derecho Privado, Derecho Objetivo, Drechos Subjetivos, vol. I, Buenos Aires, Europa-América, 1959.

, Leçons de Droit Civil, trad. esp. de Luis Alcalá-Zamora y Castillo, Lecciones de Derecho Civil - Parte Primera - Los Sujeitos de Derechos, Las Personas, vol. II, Buenos Aires, Europa-América, 1959.

, Leçons de Droit Civil, trad. esp. de Luis Alcalá-Zamora y Castillo, Lecciones de Derecho Civil - Parte Segunda - Obligaciones: El Contrato, La Promesa Unilateral, vol. I, Buenos Aires, Europa-América, 1960.

, Leçons de Droit Civil, trad. esp. de Luis Alcalá-Zamora y Castillo, Lecciones de Derecho Civil - Parte Tercera - Los Principales Contratos (continuación), vol. IV, Buenos Aires, Europa-América, 1962.

MonteIRo, Washington de Barros, Curso de Direito Civil - Parte Geral, $41^{\text {a }}$ ed. atualizada por Ana Cristina de Barros Monteiro França Pinto, São Paulo, Saraiva, 2007.

Moreira Alves, José Carlos, Direito Romano, vol. I, $13^{\mathrm{a}}$ ed., Rio de Janeiro, Forense, 2003.

, Direito Romano, vol. II, 6ª ed., Rio de Janeiro, Forense, 2003. 
A "Gewere" - Um Instituto do Antigo Direito Germânico, in Revista da Faculdade de Direito da Universidade São Paulo, vol. LXIII (1968), pp. 193-228.

Negrão, Theotonio, e GouvêA, José Roberto F., Código Civil - E Legislação Civil em Vigor, $25^{\mathrm{a}}$ ed., São Paulo, Saraiva, 2006.

Nery Junior, Nelson, e Nery, Rosa Maria de Andrade, Código Civil Comentado, $4^{\mathrm{a}}$ ed., São Paulo, RT, 2006.

Oliveira, José Lamartine Corrêa de, A Dupla Crise da Pessoa Jurídica, São Paulo, Saraiva, 1979.

PEREIRA, Caio Mário da Silva. Instituições de Direito Civil - Introdução ao Direito Civil Teoria Geral de Direito Civil, 22ª ed. atualizada por Maria Celina Bodin de Moraes, Rio de Janeiro, Forense, 2007.

Planiol, Marcel e RIPERT, Georges, (s/ título original), trad. esp. de Jose M. Cajica Jr., Tratado Elemental de Derecho Civil - Teoría General de los Contratos Especiales, vol. 5, México D.F., Cardenas, 1983.

Pontes de Miranda, Francisco Cavalcanti, Tratado de Direito Privado - Parte Geral Tomo I - Introdução. Pessoas físicas e Jurídicas, 4ª ed., São Paulo, RT, 1974. , Tratado de Direito Privado - Parte Geral - Tomo III - Negócios jurídicos. Representação. Conteúdo. Forma. Prova, $3^{\mathrm{a}}$ ed., Rio de Janeiro, Borsoi, 1970.

PôRTO, Mário Moacyr, Teoria da Aparência e Herdeiro Aparente, in RT 260 (1957), pp. 14-31.

Ráo, Vicente, Ato Jurídico, São Paulo, Max Limonad, s/d.

REQUIÃo, Rubens, Abuso de Direito e Fraude através da Personalidade Jurídica, in RT 410 (1969), pp. 12-24.

RizZArdo, Arnaldo, Teoria da Aparência, in Revista da Associação dos Juízes do Rio Grande do Sul-AJURIS, vol. 24 (1982), pp. 222-231.

RodrigueS, Sílvio, Direito Civil - Parte geral, vol. 1, 34ª ed., São Paulo, Saraiva, 2007. 
Venosa, Sílvio de Salvo, Direito Civil - Parte Geral, vol. 1, $3^{\text {a }}$ ed., São Paulo, Atlas, 2003.

Villas BoAs, Darnley, Teoria da Aparência no Direito Brasileiro, Rio de Janeiro, BVZ, 1993. 